\title{
Babel' in Context
}

A Study in Cultural Identity 
Borderlines: Russian and East European Jewish Studies

\section{Series Editor:}

Harriet MURAV_University of Illinois, Urbana-Champaign

\section{Editorial board:}

Mikhail KRUTIKOV_University of Michigan

Alice NAKHIMOVSKY_Colgate University

David SHNEER - University of Colorado, Boulder

Anna SHTERNSHIS - University of Toronto

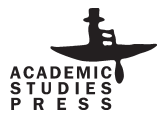




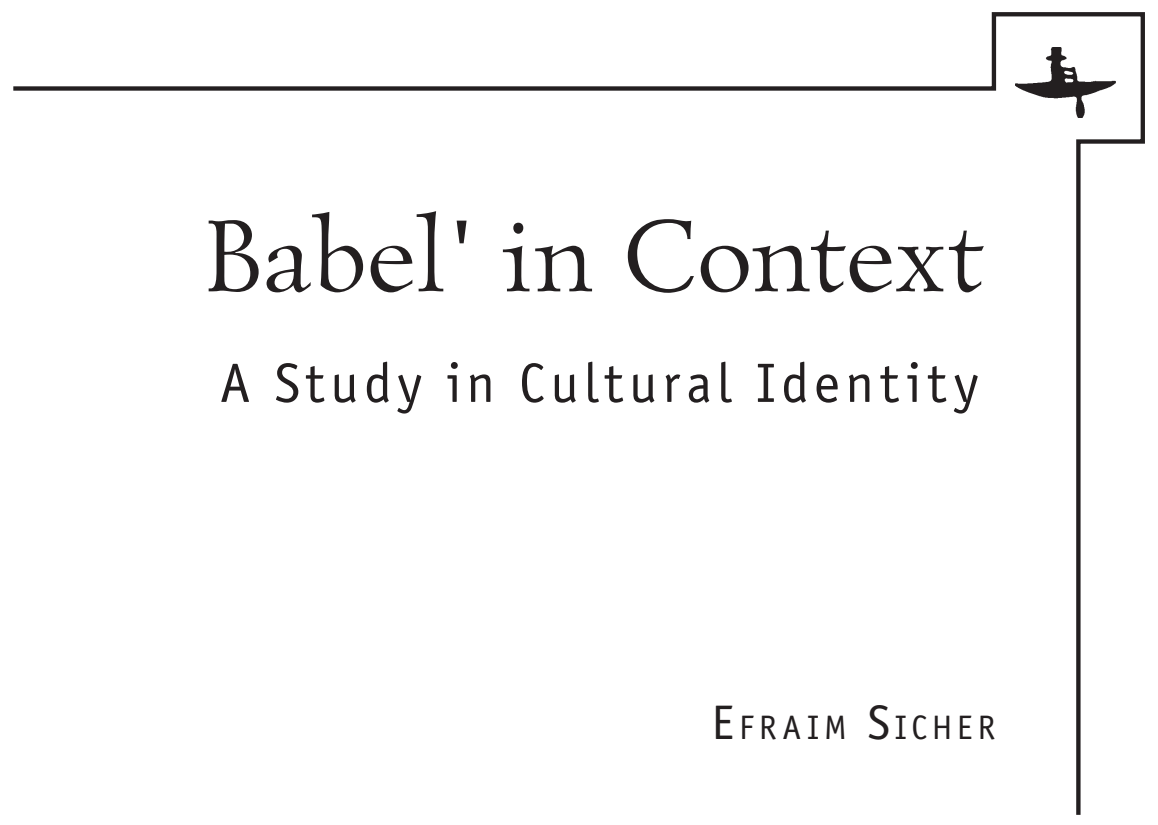

BOSTON / 2012 
Library of Congress Cataloging-in-Publication Data:

A catalog record for this book as available from the Library of Congress.

Copyright $\odot 2012$ Academic Studies Press

All rights reserved

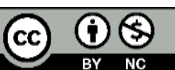

Effective July 29, 2016, this book will be subject to a CC-BY-NC license. To view a copy of this license, visit https://creativecommons.org/licenses/by-nc/4.0/. Other than as provided by these licenses, no part of this book may be reproduced, transmitted, or displayed by any electronic or mechanical means without permission from the publisher or as permitted by law.

ISBN 978-1-936235-95-7 Cloth

ISBN 978-1-61811-145-6 Electronic

Book design by Ivan Grave

Published by Academic Studies Press in 2012

28 Montfern Avenue

Brighton, MA 02135, USA

press@academicstudiespress.com

www.academicstudiespress.com 
Contents

Note on References and Translations 8

Acknowledgments 9

Introduction 11

1 / Isaak Babel': A Brief Life 29

2 / Reference and Interference 85

3 / Babel', Bialik, and Others 108

4 / Midrash and History:

A Key to the Babelesque Imagination 129

5 / A Russian Maupassant 151

6 / Babel"s Civil War 170

7 / A Voyeur on a Collective Farm 208

Bibliography of Works by Babel'

and Recommended Reading $\quad 228$

Notes $\quad 252$

Index 289 


\section{Illustrations}

Babel' with his father, Nikolaev 1904 32

Babel' with his schoolmates 33

Benia Krik (still from the film, Benia Krik, 1926) 37

S. M. Budenny, $1920 \quad 40$

First Red Horse Army, $1920 \quad 43$

Babel' in a humorous photo published alongside Budenny doing gymnastics (1933) 47

Babel' and his sister Meri in Belgium 55

Babel' and Zhenia, Idelsbad, Belgium (1928) 56

Babel' and Nathalie (1933) 57

Babel' and son, Mikhail 58

Molodenovo, $1931 \quad 59$

Babel' and Eisenstein, $1936 \quad 70$

NKVD photo of Babel', $1939 \quad 78$

Marc Chagall, Over Vitebsk (1915-20) 95

The Wise Men of Odessa 107 
Odessa tavern, ca. $1925 \quad 107$

Cover page of Den', June 1869109

Pinkhas Minkovsky and choir,

Brodsky Synagogue, around 1910109

Iosif Chaikov, cover of Baginen (1919) 125

Iosif Chaikov, cover of Breshit (1926) 125

Bialik's house, Lower Arnaut Street, Odessa 128

Monument to Pushkin, Odessa 128

Kuzma Petrov-Vodkin, 1918 in Petrograd 150

Boris Efimov, caricature based on "My First Goose” 176

Georg Grosz, "Maul halten und weiter dienen” 196

Fridrikh Ermler, still from Fragment of an Empire, 1929196

De-kulakization of peasants

in the Donetsk region, 1930s 211

USSR in Construction, November $1938 \quad 211$ 
$\underline{\text { Note on References and Translations }}$

Throughout this study I have referred to the following editions of Babel's works: Detstvo i drugie rasskazy, ed. Efraim Sicher (Jerusalem: Biblioteka Aliya, 1979) (Детствo); Sobranie sochinenii $v$ chetyrekh tomakh, ed. I. N. Sukhikh (Moscow: Vremia, 2006) (Собрание сочинений). English translations from Babel' are my own, except those taken from Collected Stories, ed. Efraim Sicher and trans. David McDuff, reissued as Red Cavalry and Other Stories (London: Penguin, 2005) (Red Cavalry and Other Stories); and from The Complete Works of Isaac Babel, ed. Nathalie Babel and trans. Peter Constantine (New York: Norton, 2001) (Complete Works). I have in some places revised the translations of the texts in the Complete Works (which is, incidentally, far from complete and based on texts published in the thirties which remain excised in places and differ in a number of respects from the earlier versions I am using). All translations of other sources are my own, except where otherwise indicated. Since not all of Babel's correspondence has appeared in the Russian original, I have occasionally been able only to quote the English translation. In matters of transliteration, I have preferred inconsistency to unreadability. 
Acknowledgments

I am grateful to a host of friends and colleagues who have over many years, perhaps too many, encouraged me to write this book and offered comments or engaged in a conversation about Babel's cultural identity. In particular I would like to thank, if I may be excused a partial list that is impartially ranked in alphabetical order, Mordecai Altshuler, Carol Avins, Joost van Baak, Hamutal Bar-Yosef, Galina Belaia, Patricia Blake, Donald Fanger, Gregory Freidin, Maurice Friedberg, Amelia Glaser, Alena Iavorskaia, Rina Lapidus, Mirja Lecke, Zalman-Simkha (Stiv) Levin, Svetlana Natkovich, Alice Nakhimovsky, Elena Pogorelskaia, David G. Roskies, Batia Valdman, and Ruth Wisse. I am also indebted to the support of the Nevzlin Center for the Study of Russian and East European Jewry at the Hebrew University of Jerusalem. The publication of this book was made possible by grant \#1839/11 from the Israel Science Foundation. Additional expenses were defrayed by the Dean of the Faculty of Humanities and Social Sciences, Ben-Gurion University of the Negev. At Academic Studies Press, Sharona Vedol, Kira Nemirovsky, and their staff valiantly grappled with a text in several languages that ran in two directions. Finally, there are debts that will not be repaid in this world: to Toby Holtzman, patron and benefactor of Babel' studies, and to Antonina Nikolaevna Pirozhkova, without whom I would not have had the access I enjoyed to Babel's manuscripts. This book should be seen as a tribute to their quiet but determined efforts to keep Babel"s memory alive and to the memory of two persons who, in their different ways, were passionately dedicated to Babel'. 
Earlier versions of parts of the chapters or passages in this book first appeared in journal articles in Slavonic and East European Review, Studies in Contemporary Jewry, Revue des études slaves, New Zealand Slavonic Journal, Shout, Aschkenas, Canadian Slavonic Papers, Paralleli (Moscow), and Dapim lemekkhar besifrut (Haifa University). A shorter version of chapter three has appeared as "Text, Context, Intertext: Babel', Bialik, and Others," in The Enigma of Babel: Life, History, Context, ed. Gregory Freidin (Stanford: Stanford University Press, 2009), pp. 193-212. A somewhat different version of chapter four was published as "Midrash and History: A Key to the Babelesque Imagination," in Isaac Babel's Selected Writings: Norton Critical Edition, ed. Gregory Freidin (New York: Norton, 2010), pp. 483-94. 


\section{INTRODUCTION}

Не надо даром зубрить сабель, меня интересует Бабель, наш знаменитый одессит.

Он долго ль фабулу вынашивал, писал ли он сначала начерно иль, может, сразу шпарил набело, в чем, черт возьми, загадка Бабеля?..

-С. Кирсанов

Don't get into a lather rattling your saber, It's Babel' I'm after, our famous Odessite.

Did he chew the story over for ages, or write everything in drafts, or maybe he shot it straight out, what is, damn it, the enigma of Babel'?

$-\mathrm{S}$. Kirsanov ${ }^{1}$

Who was Babel'? Where did he come from? He was an accident. We are all such accidents. We do not make up history and culture. We simply appear, not by our own choice. We make what we can of our condition with the means available. We must accept the mixture as we find it - the impurity of it, the tragedy of it, the hope of it.

-Saul Bellow ${ }^{2}$

\section{The Odessa File}

Moscow, 1994. The gods of communism had fallen, along with "law and order." A crippled child holding up an icon and clutching a begging bowl beneath the icon of the new ideological system, Macdonald's, seemed to sum up the drastic changes that had been set in motion by the collapse of communism. I was invited, 
as an Israeli scholar who had published two volumes of Babel"s stories in Russian, to a conference marking Babel"s centenary at Moscow's Russian Humanities University. The event was held "under the cloak" of a Zoshchenko conference. It seemed that the time was not yet ripe for Babel' to come out fully as a major author of the Soviet period. Why was this so? Why had Babel' not emerged yet from the gray zone of cautious and partial publication under perestroika? If Russian literary history was now ready to admit all writers, including dissidents and émigrés, what was the place to be inscribed under Babel"s name in the annals of Russian culture?

It transpired that there were (at least) two Babel's - the Jewish and the Russian writer. Over seventy years had passed since a symbiosis had existed in a hyphenated Russo-Jewish identity. Little was remembered of the flowering of that nascent writing by Russian Jews, less still of the great renascence of Hebrew and Yiddish literature in Russia's major cities (most famously in Odessa, Babel's native town), all vestiges of which were repressed during the Stalinist "Black Years" and afterwards. Under the title of "Soviet author," Babel' was held in respect as an experimental prose writer who became a "master of silence" before being swallowed up by Stalinism," yet, after the fall of communism, he was also denigrated as the "Marquis de Sade" of the Bolshevik Revolution. ${ }^{4}$ In the reawakened Russian national consciousness, Babel' was at best marginal, at worst alien and hostile. Of course, in a post-revolutionary context, a Soviet Russian Babel' did not exclude an iconoclastic, highly individual Babel', who owed allegiance to no Party or ideology, who passionately loved Yiddish, and might equally fit in with Russian prose of the twenties and the modernism of the revived Hebrew literature and its Yiddish rivals. By the twenty-first century, Babel' had become part of the cultural identity of a Russian-speaking, Jewish readership in Russia and Israel; indeed, he had become one of the iconic symbols of that cultural identity, bolstering the return to Jewish traditions or secular Jewish identity. A Jewish culture festival was held in Odessa in 2004 featuring Babel' and the Odessa past, and a monument to the writer was unveiled at a Babel' festival in 2011 (starring, among other celebrities, the stand-up 
comic Mikhail Zhvanetskii). In Moscow, Babel' was slated to enter the pantheon of Jewish cultural heroes in the projected House of Tolerance (the Moscow Jewish community's museum and cultural center).

Isaak Babel' was born in the Moldavanka, a squalid working-class district of Odessa, on 13 July (30 June, O.S.) 1894, to Emmanuel and Faige (Fenia). The family's original name appears to have been Bobel (בל in Hebrew is "Babylon"). In 1895 the Babels moved to Nikolaev, where Emmanuel was employed in the Birnbaum company that traded in agricultural machinery and where Isaak studied at the S. Witte Commercial School. In 1905, they sent young Isaak ahead of them to Odessa to lodge on Tiraspol'skaia Street with Aunt Katia (Gitl), before settling around the corner in Dal'nitskaia Street. They then moved to Richelieu Street, in the fashionable center of town. The family seemed not to have been affected by the 1905 pogroms. ${ }^{6}$ In 1906, Babel' enrolled in the Nicholas II Commercial School, which was open to Jews without restriction, and was tutored at home in Bible and Hebrew, like so many sons of the Odessa Jewish middle classes. The anti-Jewish quota, however, was to keep Babel' out of Odessa University, and he studied business management at the Kiev Institute of Financial and Business Studies. Business management offered a natural choice of career under the Tsars, when many professions were closed to Jews. During his studies in Kiev, Babel' mixed with the local assimilated Jewish intelligentsia, including the family of a business associate of his father, Boris (DovBer) Gronfein, whose daughter Evgenia (Zhenia), a budding artist, he would marry in 1919.

The entry of a Jewish intellectual into Russian letters under the Tsars often cost some degradation in order to reside in St. Petersburg or Moscow; sometimes the price was apostasy. Leonid Pasternak, the Jewish painter from Odessa and father of the famous poet, was something of an exception in this respect when he settled in Moscow in the 1890s. Babel' was fortunate, and lodged both legally and not uncomfortably with the family of an engineer, Lev Il'ich Slonim, while studying law at the Neuro-Psychological Institute, a liberal arts college well known for the revolutionary activity among its students. Nevertheless, in his "Autobiography" 
(“Автобиография"), Babel' bragged that he lacked the residence permit required of Jews and lived in a cellar with a drunken waiter while on the run from the police.

These simple biographical facts, however, do not help us penetrate the enigma of Babel', a short, stocky man with glasses and glistening, curious eyes; compulsively elusive even before the Stalinist years, when incautious words could condemn and betray; obsessively secretive well before loud conformism was the rule; naturally mischievous, with a tendency to play pranks on his closest friends, ${ }^{7}$ and devious in his dealings with editors at a time when the regime demanded a steady output of ideologically correct material. His evasiveness and long disappearances did not begin with the desperate need to hide from creditors and everyone else in order to write in peace, or with the tactical silences of the thirties, when he would have his daughter Lydia answer the phone with "Papa's not at home," to which she could not help adding (being her father's daughter), "he's gone out in his new galoshes." ${ }^{8}$ Early on he developed a tendency to disappear for lengthy periods of time and would write to his friends asking them to undertake various commissions for him. He wrote to his friends the Slonims in Petrograd (St. Petersburg) in December 1918, after one such disappearance, "I found myself in a situation where I was ashamed to appear in public, then I was ashamed of not appearing.... In my character there are irrepressible traits of endurance and an impractical relationship with reality... From this derive my voluntary and involuntary transgressions. ${ }^{\prime 9}$ He had children by three women, yet essentially remained the Jewish family man, caring for his family abroad and being disastrously overgenerous with his Odessa relatives. He craved freedom, but could not breathe freely outside Russia, for all its poverty and the stifling repression of Moscow's literary world. Babel' returned to Stalin's Russia because this was where his writing material was: the historic upheavals of revolution and Civil War, the transformation of a backward country into a modern industrial state, a country where the grotesque contradictions of human nature fascinated him, and where the moral obligation to record the terrible human price of building socialism dictated his painstaking craftsmanship. 
Who was Isaak Babel'? The American Jewish novelist Saul Bellow, puzzling over why a writer so characteristically Jewish as Babel', who knew Yiddish well enough to write in it, chose to write in the language of the pogromshchiki, answered this question by saying that we are all accidents of history. ${ }^{10}$ I would agree that we are born in a time and place, and into a language and culture, not of our choosing, but out of that time and place each of us makes something that is uniquely ours.

Babel' was born in a time and place that were to be a crossroads of history and was himself to die as the victim of circumstances which he saw only too clearly, perhaps earlier than most. Cultural identity may be shaped by the individual, but it grows out of a literary, ethnic, and linguistic context. As David Theo Goldberg and Michael Krausz have observed in their introduction to a study of the metaphysical and philosophical meanings of Jewish identity, identity is as much a cultural and social formation as a product of personal circumstance, and it is always in process. ${ }^{11}$ However, in order to properly understand the individual writer within the interactive intersections between self and the cultural milieu, this book will follow three parameters: text, context, and intertext.

Babel"s formative years coincided with the renascence of Jewish national consciousness and cultural revival in the aftermath of the Kishinev pogroms. As Kenneth Moss has shown, the liberation of the Jews in February 1917 from centuries of Tsarist restrictions and segregation triggered a multitude of diverse and conflicting plans for a Jewish culture, whether in Hebrew, Yiddish, or Russian, from the Bundist to the Zionist. These various plans conceptualized a future Jewish identity evolving out of culture, rather than politics. Nevertheless, many Jews were caught up in the furor and excitement of revolutionary Russia, and saw politics as a means to achieve both cultural and ideological ideals, but were overtaken by events when the Bolsheviks suppressed existing Jewish communal organizations and gradually took control of cultural production. ${ }^{12}$ The communist takeover did enable many Jews to advance up the echelon of new administrative institutions (including the secret police) and whitecollar professions (including publishing and literature); the tragedy 
was that it spelt economic disaster for the already war-ravaged Jewish community in the shtetl.

Babel' grew up among a remarkable mix of speakers of Yiddish, Hebrew, Russian, and Ukrainian speakers, in the vibrant Jewish cultural center of Odessa, ${ }^{13}$ and could, after the turmoil of the Bolshevik coup and Civil War, blend into Russian literature of the 1920s, when ethnic distinctions mattered far less than class origins. Babel' managed to publish before the collapse of Tsarism a manifesto which called for a literary messiah from Odessa, a Russian Maupassant. In "Odessa" (1916), he prophesied that this cosmopolitan port on the Black Sea could bring the sun to Russian literature. Russia's much-needed literary messiah might come from Odessa, he claimed, and break St. Petersburg's icy grip on Russian literature so as to breathe life into a stifling prose full of turgid stories of boring provincial towns in the north. Babel' casts his poetic identity in the mould of Maupassant, his muse and acknowledged literary master, but writes in "Notes from Odessa" ("Дистки об Одессе", 1918) as a Jew from cosmopolitan Odessa, which, in the first half of the nineteenth century, welcomed foreigners, including its French governor and a number of Jews from Galicia. ${ }^{14}$ In fact, as John Klier has demonstrated, Odessa's "port Jews" benefited from the distinctive situation of the city and developed modern forms of Jewish culture. ${ }^{15}$

It was in Odessa that the coexistence of different culturesdespite ethnic tensions, for example between Greeks and Jewsmade possible the natural development of a "minor modernism" in this periphery of the Russian empire. By the end of the nineteenth century, a third of the city's population was Jewish, concentrated in certain areas of the city; with the influx of refugees during the First World War the proportion swelled and, despite emigration and the disruptions of revolution and Civil War, attracted further migration from shtetls and outlying areas, reaching $41.1 \%$ of the total population in $1923 .{ }^{16}$ The cultural contacts between Jews, Russians, and Ukrainians in the period of burgeoning modernism in the early twentieth century have not been fully investigated, despite the fact that Jewish culture centered in Odessa, as well as Warsaw, Vilna, and a few smaller provincial towns, was to be formative in modern 
Jewish cultural identity and, later on, Israeli literature. Odessa was one of the freer cities in the Russian Empire and it was open to Western influences in its architecture, politics, art, music, and cultural life, not to mention its more "Levantine" or Mediterranean lifestyle. The influence of the West and of Maupassant in particular, as we will see in a later chapter, was to shape Babel"s aesthetics in unique ways.

Odessa's cultural memory evokes nostalgia for an imagined carnivalesque liberty and Jewish joie de vivre, but also bourgeois affluence. This was a vibrant center of Jewish culture, erased from the memory map of history by emigration to America, seventy years of communism, and Nazi genocide. To reinvent that vanished world is to read through the distorting lens of former maskilim and émigrés, the retrospective memoirs and fiction of Jabotinsky, and the stories of Babel' himself. ${ }^{17}$ The postmemory of "Old Odessa" has been further mythicized in books, folksongs, anthologies, and films which celebrate a folklore of "Jewish" criminality, characterized by Yiddish humor. Odessa's own Russian dialect, but also thieves' cant, later lent a coded euphemism to Jewish ethnicity, when Jewish cultural identity had become taboo or officially erased from Soviet official discourse. In fact, the Odessite has become a comic character, the wily conman of the NEP period, such as Il'f and Petrov's Ostap Bender who knows how to negotiate and subvert the Soviet system (though he is never identified as Jewish or an Odessite). The Odessa myth shifted from the classical topos of Russian cultural identity, centered on dreams of imperialist expansion to the Black Sea and domination of the Balkans and Asia Minor, to a construction by mid-nineteenth-century maskilim of commerce combined with cosmopolitanism that rapidly became an ethos of Jewish diversity and a Jewish city of vice and sin. That fiction of Jewish criminality easily lent itself after the October Revolution to the more subversive legends celebrating opportunity and carousing, when banditry and financial speculation had been outlawed by the Bolshevik regime, the synagogues and cafés turned into workers' clubs. ${ }^{18}$ In 1926, the city was officially Ukrainianized, after most vestiges of independent Ukrainian nationalism had been wiped out, but a memory of Odessa's unique blend of Russian, 
Yiddish, and Hebrew culture lived on for a while, even after the last Jewish cultural institutions had been taken over and the Zionists driven underground. The further destruction of the remaining memory of Odessa Jewish life in the Holocaust, when Odessa was occupied by the Rumanians and the city's Jews were murdered, may explain a belated post-Soviet impetus for elderly Odessites and émigrés in Ashdod and Brighton Beach to celebrate the mythicized past and share collective loss, documented in Michale Boganim's film Odessa, Odessa (2005). One could say that Odessa's cultural memory has acquired a life of its own. ${ }^{19}$ Even today, Odessisms and Odessa lore have left their mark on popular Russian song, ${ }^{20}$ and Odessa has achieved something of an afterlife in post-Soviet fiction, for example, Irina Ratushinskaia's The Odessans (Odeccumbl, 1998) or Rada Polischuk's “Odessa Tales, or the Incoherent Alphabet of Memory" ("Одесские рассказы, иди путаная азбука памяти”, 2005).

Odessa lore, literature, and language offer a further dimension to the intercultural identity of Babel"s Russian prose, for this meeting-point of Jewish and Russian cultures, mixed with heavy French, Italian, and other foreign influences, gave birth to a putative "South-Western School" of Russian literature that includes Babel', Eduard Bagritsky, Yurii Olesha, Vera Inber, Konstantin Paustovsky, Lev Slavin, and Valentin Kataev, as well as Il'ia Fainzil'berg, better known as the Jewish member of that comic duo, Il'f and Petrov. From the early twenties, these young talents breathed some warm Odessa sunshine into Moscow literary circles. In fact, most of them made their name in Russia's capital in the twenties, where they were part of a wave of regional and exotic voices, in a celebration of the underworld and the peripheral. Such claims to independent literary groupings were controversial and risky under Stalin. The formalist critic Viktor Shklovsky soon had to retract his formulation of a "South-Western School" of writers under ideological pressure to conform to a centralized scheme of literature under Party control that became increasingly intolerant of individualism and separatism, not to mention romantic fellow-travelers, as most of the Odessites were. ${ }^{21}$ Nevertheless, Yuri Shcheglov states that it is an "established fact" that the "South-Western School" contributed a West European 
prose style to the Russian realist tradition, and opened up the borders of Russian literature through intertextuality. ${ }^{22}$ And perhaps only an Odessa Jew could combine Pushkin and Sholom Aleichem, or have the audacity to propose an Odessa Maupassant as Russia's literary messiah. Rebecca Stanton puts it more precisely when she writes that it was more a case of reclaiming and then appropriating the Russian literary tradition associated with Pushkin, who was forever associated with Odessa since writing Evgeny Onegin there. ${ }^{23}$ In her book-length essay, the Odessa journalist Elena Karakina makes some sweeping claims for the existence from the twenties of a putative Odessa school as a counterpart to the Russian cultural tradition based in St. Petersburg (Petrograd/Leningrad) and Moscow. ${ }^{24}$ Nevertheless, it should not be forgotten that Semyon Yushkevich and O. L. Korenman ("Karmen") were writing about local Odessa life well before Babel' made Benia Krik king of the gangsters. Besides Osip Rabinovich's Morits Sefardi (Мориц, Сефардu) and Kaleidoscope (Калейдоскоn), Yushkevich's novel Leon Drei (Леон Арей) covered this ground in 1913-15, and his 1908 play, The King (Король), described a revolt of a philistine magnate's sons like that of Mendel's sons in Sunset (3akam, 1928). The Odessa underworld had also been explored by Kuprin, in "Gambrinus" (Гамбринус", 1906) and "Offense" ("Обида", 1906), about Odessa gangsters who disassociated themselves from the pogromshchiki. And yet Odessa is more often than not "remembered" through Babel"s Odessa tales.

\section{The Enigma of Babel'}

Babel's Russian prose was considered to be exemplary. The critic and editor of the Soviet journal Krasnaiia nov' (Red Virgin Soil), Aleksandr Voronsky, writing in 1925 (before Babel' had published a single book), declared that Babel"s prose showed firmness, maturity, self-assurance, and craftsmanship, which is testimony to culture, intelligence, and hard work (“твердость, зрелость, уверенность, нечто отстоявшее, есть выработка, которая дается не только талантом, но и упорной, усидчивой работой"), superior to much Soviet fiction, and it reflected a turn away from experimentalism, toward realist classicism. ${ }^{25} \mathrm{He}$ had, wrote Voronsky, created a sui 
generis epic style, and was close to the revolutionary spirit, but there was something almost pagan and un-Christian in his preoccupation with the flesh. Babel' ranks along with Platonov, Olesha (a fellow Odessite), Bulgakov, Pil'niak, and Zamiatin's Serapion Brothers as a leading Russian modernist. Zamiatin, in "On Literature, Revolution, and Entropy," thought of the writer as a heretic who viewed the world at 45 degrees from the deck of a ship in a storm, ${ }^{26}$ and commented that Babel"s brilliant mastery of skaz in "The Sin of Jesus" ("Иисусов грех") did not let him forget he had a brain, as often happened in ornamentalist prose: "this tiny tale is raised above prosaic everyday life and is illuminated with serious thought." ${ }^{27}$ Shklovsky famously summed up Babel's style by saying that he spoke in the same tones of the stars and gonorrhea. ${ }^{28}$ But perhaps it is precisely this innovative style that marks Babel' as an outsider who sees Russia with an eye for the grotesque, the absurd, and the tragic in what is essentially human.

Part of the puzzle of cultural identity may lie in the intertextuality that characterizes modernism, which renewed traditional forms in art and literature, such as folk motifs and myths. This was true for both Russian modernism and the Jewish renascence of 19121925. Intertextuality underlies Jewish writing through the ages and its use of linguistic play helped to evade censors, inquisitors, and hostile regimes in Spain and in Russia. Moreover, the fact that Babel' and other Russian Jews were often multilingual allowed them to create variant subtextual meanings for Jewish readers, as will be seen in the following chapters. At the beginning of the twentieth century, Yiddish, Hebrew, and Russian were not separate spheres of cultural activity; that is to say, not only did Russian Jews write in more than one language, but when they began to move freely in Russian society, they could address different audiences, sometimes simultaneously. When David Shneer declares that Babel' did not work in Yiddish, and therefore could not claim the role of a cultural translator, ${ }^{29}$ implying he must be excluded from a history of Soviet Jewish culture, Shneer is ignoring Babel's translations from Yiddish, his immersion in Yiddish classics, and his use of Yiddish in his Russian prose. Similarly, Kenneth Moss's claim, in view of the fierce competition between a Hebrew cultural project 
(later realized in the Land of Israel) and Yiddish (which established a major secular and socialist cultural center in the Soviet Union in the twenties), that Russian did not play a significant role in the formation of a post-revolutionary Soviet Jewish intelligentsia ${ }^{30}$ discounts the role of Jewish artists and writers who moved freely in both Russian and Jewish circles. Indeed, Soviet Jewish Communists who struggled to establish Yiddish as the Soviet Jewish culture were fighting a losing battle with Russian which was a powerful assimilatory and socially mobilizing force. Harriet Murav has demonstrated that Russian Jewish literature shared the heritage and themes of Yiddish modernism, as well as collective memory of pogroms, noting that Babel' was "looking over his shoulder at Yiddish." ${ }^{31}$ I will argue that Babel' lived in the secular Yiddish tradition and not only enjoyed the mutual admiration of leading Yiddish cultural figures, but, like them, looked to a socialist future while mourning the loss of the Jewish cultural past. His stories appeared in Yiddish translation, and his own translations of classic and contemporary Yiddish writers and his film work attest to his immersion in Yiddish; not only that, but, as I shall show, the Yiddish language breathes in the coded subtexts of his Russian prose.

If Jews had previously been unwanted guests in Russian culture, after the Bolshevik takeover they rushed to fill the vacuum left by the Russian intelligentsia. Russia was, when all was said and done, their native land, and for this generation Russian was their native language, even if this was contentious in the 1908 debates between Kornei Chukovsky, Jabotinsky, and others and at the Czernowitz conference. But acculturation had a price. In a letter to Gor'ky in 1922, Lev Lunts, a leading member of the Serapion Brothers, spoke of an inner conflict, an "ethical contradiction," between his pronounced and strong sense of Jewish identity and his allegiance to Russia and Russian literature: "I'm a Jew, staunch, loyal, and glad to be one. And I'm a Russian writer. But I'm also a Russian Jew, and Russia is my homeland, which I love more than any other country. How does one reconcile these?"32 Alice Nakhimovsky, in her study of Russian Jewish writers, points to Babel"s writing as the "densest picture in all of Russian literature of the Jew between two worlds." 33 
Jews soon learned to be hypersensitive to accusations of "nationalism," especially if they had a Bundist or Zionist past to conceal. Now they tried to achieve a new transparency in order to differentiate themselves from the old ("bad") Jew and to claim status as a new ("good") Jew who had cut himself off from his own past and had learned the lesson of pogrom experience, according to Party propaganda a phenomenon of the feudal Tsarist system, which taught that national difference was a symptom of the class struggle and that anti-Semitism would disappear along with the capitalist bourgeoisie. Opting for Russian became a statement of ideological identity, since Yiddish and Hebrew reverberated with old ways and the continuity of Jewish national existence. Alternatively, Russian could be coded with the covert language of the Other for those Jewish readers who were bilingually proficient, and who were painfully aware that the large representation of Jewish names in the Communist Party or in Soviet cultural institutions and the popular association of the Jew with the entrepreneur in the temporary retreat to limited capitalism during NEP meant no end to "Jewish troubles." On a grain requisition expedition on the Volga in "SS Cow-Wheat" ("Иван-да-Марья") in 1918, Babel"s narrator is reminded that he is a Jew who will always be a foreigner in his native Russia.

The distance traveled from the Jewish past by the Soviet Jew writing in Russian is measured in the politically correct declaration of class allegiance and the willingness to condemn the Jewish religion and bourgeoisie. In the Komsomol poet Mikhail Svetlov's "Verses about the Rebbe" ("Стихи о ребе", 1923), the narrator guards the future and when he turns to the East, towards Jerusalem, the traditional orientation of Jewish prayer, it is only to see if his Komsomol comrade is coming. The rebbe and the priest alike are doomed to die with the old world. They are both branded with the stereotyped accusation of financial speculation, that is to say, economic sabotage and anti-Communist, disloyal behavior. The sunset splashes the shtetl and its dark, empty synagogue with the red of the Red Flag and the faded Talmud is rejected. In "Bread" ("Хиеб", 1929) a new kinship is discovered between the pogromscarred Jew Samuel Liberzon and the Russian former pogromshchik Ignatius Mozhaev, the class solidarity of fathers who have lost sons 
fighting for the new regime. Svetlov at least remembered the Jewish past with some melancholy and pain, and described the Jewish revolutionary martyr as a new Moses on a Soviet Sinai, a proud descendant of the Maccabees.

Eduard Bagritsky, a poet from Odessa, went so far as to curse his Jewish parentage in "Origins" ("Происхождение", 1930) and made the typical break with Jewish rituals which had lost any meaning for the revolutionary Jewish youth. There is little that is specifically Jewish in Bagritsky's favorite themes of hunting and fishing. ${ }^{34}$ When it came to defining a collective memory for the next generation, Bagritsky referred in his "Conversation with My Son" ("Разговор с сыном", 1931) to the archetypal image of feathers flying in a pogrom, but the hope which he bequeathed to the next generation was of an internationalist universe where such things did not happen. The dream of universal social justice remained far off. Meanwhile, Bagritsky, a professing atheist caught up in the romanticism of the communist revolution, remained nostalgic for his native shore. In "Return" ("Возвращение", 1924), and, in a posthumously published long poem "February" (“Февраль", 1933-1934), he marveled at how a sickly Jewish boy like himself had become a poet with a love for nature and for women. He does not hide his circumcision and does not jibe, like the Yiddish poet Itsik Feffer, "so what if I'm circumcised?" More obliquely, Bagritsky's translation of 1927 from Itsik Feffer's long poem Dnieper (Днепр) does not evoke the poet's native Ukrainian landscape without recording the children thrown into the river during the Civil War. Babel', Bagritsky's friend and fellow Odessite, eulogized him after his death from tuberculosis in 1934 as combining the spirit of the Komsomol and "Ben Akiva" (Собрание сочинений, III, 373). ${ }^{35}$

The examples of Svetlov and Bagritsky (as well as Iosif Utkin, as will be seen) illustrate the paradox of the Soviet Jewish Communist, who had to prove his loyalty to international communism and the Soviet state by demonstrating negation of anything remotely "nationalistic"; that is to say, Jewish. But to sever oneself from one's own memory of past and family did not solve the problem of identity. Jews who changed their names to "neutral" Russian or 
demonstratively Russian revolutionary names still had to prove their hatred for their ethnic past more than their non-Jewish comrades (which did not help them when, during Stalin's postwar "anti-cosmopolitan" campaign, many writers and critics were "exposed" in the press by having their original names published in the attacks on them). The Evsektsiia, the Jewish section of the Soviet Communist Party, showed particular zeal in persecuting all forms of religion and was instrumental in repressing Jewish cultural institutions before being liquidated itself. ${ }^{36}$ In recent years, Jews have been singled out by anti-Semitic detractors who held them guilty for the damage done to Russian churches, as well as for the famine in the Ukraine caused by enforced collectivization, since so many Party leaders and activists were identified as Jews. However, in the first decade after the October Revolution it was easier for Jews to deal with anti-Semitic stereotypes in Russian literature, since discrimination had been officially eliminated with the old order, but it was harder to deal with continued prejudice among the masses. A short novel, for example, by an otherwise conformist writer, Mikhail Kozakov, The Man Who Prostrated Himself (Человек, падающчий нии, 1928), records the painful experience of anti-Semitism that persisted despite official Party policy and propaganda.

\section{Double Book-Keeping}

In an anthology of Spanish Jewish poetry, Spanish and Portuguese Poets: Victims of the Inquisition (Испанские и португальские поэты, жертвы инквизиции, 1934), the Soviet Jewish poet and critic Valentin Parnakh wrote of Jewish poets in Russia as Marranos, referring to Jews who outwardly converted to Christianity under the Inquisition but secretly practiced Jewish rites. This was an analogy made famous by Moisei Maimon in his painting The Marranos (Mappatbl, 1893), which alluded to the persecution of Moscow Jews by the Tsarist police. Aware of their Marrano status, writers like Babel' could code their Russian with the covert language of the Other for those Jewish readers who were bilingually proficient in the "hidden language" of the Jews ${ }^{37}-$ a kind of "double book-keeping." "Double bookkeeping" ensured an ideologically safe cover, while a clandestine 
subtext spoke to a different cultural and linguistic knowledge and a different understanding of historical events from the perspective of centuries of Jewish suffering. By contrast, Mandelstam and Pasternak espoused cultural forms of Russianness and Christianity, while that eternal chameleon Ehrenburg changed his skin with regimes and party policies, like some people changed shoes when they no longer fit. ${ }^{38}$ The poets Bagritsky, Utkin, and Svetlov, each in his own way, turned their backs on the Jewish past and used Yiddish and Jewish references to identify themselves in relation to what was being abandoned rather than shared. ${ }^{39}$ By contrast, in Aleksei Svirsky's Story of My Life (История моей жизни), the hero David reverts to Yiddish after a pogrom experience makes him wish to leave Russia. ${ }^{40}$ In the post-revolutionary years, nevertheless, Yiddish could merge with dialect, regionalism and slang in spoken Russian and in literature, but for Jews it remained a sign of identification of cultural and ethnic origin, as well as marking artistic and ideological transition, for example in Lissitzky's use of calligraphy and Hebrew texts in his illustration of Ehrenburg's "The Steamship Ticket" ("Шифс-карта") or of the Haggadah. ${ }^{41}$ And, of course, Yiddish was an obvious element in the Odessisms and criminal slang in the early stories of Il'ia Il'f (Fainzil'berg), as well as the double-edged satire of Il'f and Petrov's Twelve Chairs (Двенадияать стульев, 1928), which is reminiscent of Sholom Aleichem's Menachem Mendel stories. ${ }^{42}$ Still, of all the Jews who wrote in Russian after the October Revolution, none was more skilled in Jewish subtexts than Babel', and for none of them were Jewish identity and Yiddish as natural and inbred as they were for Babel'.

This book argues that Babel's cultural identity is complex and presents it as a case study of an acclaimed Soviet Jewish writer who made Russian culture his own, yet was able to introduce into Russian literature Jewish characters who were strong and independent, confident in their identity. ${ }^{43}$ As a writer entirely at home in both Russian and Jewish cultures, Babel' caught the cruel ironies of the situation of the Jew who lived in both worlds and understood the irony that the new socialist order was destroying the Jewish past. Yet Babel' himself never seems to have lost hope that socialism would bring a better future. At the same time, however, to think of Babel' 
is to think of other Jewish writers in eastern and central Europe who grappled with the confrontation of modernity that brought both a strange new world of revolution and technology and antiSemitic violence but who also served as mediators of European modernism.

The first chapter explores the fate of Babel' as a writer who refused to compromise his literary integrity, in an age when very few survived who did not compromise. Through an account of Babel"s literary career based on archival sources, newly discovered correspondence, and memoirs, we will see the contradictions and conflicts behind the enigma of Babel'. This is a story of literary politics in Stalinist Russia, as well as a personal tragedy ending in the loss of a great writer in his prime who could never write "to order."

The second chapter of this book opens with a discussion of the theoretical underpinnings and historical background of the intertextual relationship between Russian, Hebrew, and Yiddish culture, with an analysis of subtexts in Babel's stories. The instances I look at in particular, playful puns and double meanings in Yiddish, tell us a lot about the workings of referentiality in creating subtexts within a literary polysystem.

In Odessa, Babel' knew Bialik and Mendele, among the great figures of modern Hebrew and Yiddish literature, and in the Red Cavalry stories there are surprising resonances of Bialik's verse, which most Jewish readers would have known by heart in the original or in Russian translation. A close reading of passages from Red Cavalry (Конармия) unearths these intertextual clues to Babel"s "double book-keeping." Liutov's encounter with his alter ego, Il'ia Bratslavsky, is not a fantasized invention of a Hebrew Communist, but uncovers a forgotten episode in Soviet Jewish history and Hebrew literature, in which Babel' was involved through his contribution of a selection of his stories to a Hebrew communist journal.

The Hebrew Communists were deluded idealists, who wished to translate the vision of the prophets into the construction of a socialist society. But Babel' never lost his sense of irony in his insight into history. A radical perspective of history is afforded by Babel"s "midrashic" reading of myth. We will see that a "midrashic" 
approach not only produces surprising and unlikely juxtapositions, but shows history to be cyclical, rather than dialectical, as in its orthodox Marxist interpretation. Moreover, there appear to be alternate perspectives of history, the Jewish and the Russian, each with their literary and cultural referents.

Babel's love of Maupassant was to result in more than a straight literary influence, and chapter five looks at Babel"s imaginative reworking of the French author's stories into a debate over the price the artist has to pay for genius and fame. This is also a debate over the ethics of art which pits Tolstoy against the combined intertextual voices of Maupassant and Chekhov in two of Babel"s stories, "Guy de Maupassant" ("Гюи де Мопассан") and "The Kiss" ("Поцелуй"). What emerges from Babel"s stories and his own translations of Maupassant is a meditation on art and the artist that questions the personal and moral cost of artistic success, but without giving up on an Odessa Jew's joie de vivre, even if, like Gogol' and Chekhov before him, or his contemporary Zoshchenko, he sees trite vulgarity (poshlost') all around him. ${ }^{44}$

A comparison in the following chapter of the Red Cavalry stories with other epics of the Russian Civil War, such as Furmanov's Chapaev (Чanaeв) or Fadeev's The Rout (Разгром; also translated as The Nineteen) asks how much Babel' differs from his contemporaries and how much the ideological struggle over the representation of the October Revolution affects his writing. I will show Babel' to be a child of his time and at the same time an original voice in Soviet prose of the 1920s. Nevertheless, Babel' bears resemblance with the extraordinary aesthetic quality of the everyday experience of modernity, which we find in Conrad, Joyce, and Woolf. In particular, the diary Babel' wrote during Budenny's campaign in Poland in 1920 and the drafts of the Red Cavalry stories reveal a deeply anguished mind, torn over moral dilemmas and split between the ideals of the revolution and his own Jewish roots as he witnessed the violence of war and the suffering of his fellow Jews. Babel"s distinctly modernist portrayal of war and the disturbing lyricism of a violent landscape deserve comparison with other modernists in Hebrew and Yiddish, including one on the other side of the RussoPolish front, the Yiddish novelist Israel Rabon, whose shocking 
account of the same war reverberates with some of the imagery and perspectives of Red Cavalry.

The final chapter takes us to another, more terrifying scene of combat, the collectivization campaign. However, here there was little room for equivocation. Babel' was witness to Stalin's forced collectivization of villages in the Ukraine in 1929-30 and was horrified by the monstrosity of the mass expulsion, deportation, and destruction of traditional ways of life: millions were exiled or died in the name of Stalinism. Yet the detachment of the narrator of Red Cavalry is taken to a further unnerving level of morally shocking observation. The book Babel' never completed about collectivization, Velikaia Krinitsa, stands out in its powerful selfrestraint when compared with Sholokhov's Virgin Soil Upturned (Поднятая иелина) or the turgid conformist prose of the 1930s.

By reading Babel' comparatively, I aim to reread Babel' as a complex figure who was not aligned with any literary group, yet whose iconoclastic art was very much in tune with the modernism of his times. At the same time as he negotiated his own personal dilemma between women, countries, and families and struggled as a Soviet author to survive in an age of ideological demands and purges, he remained a deeply Jewish writer in his outlook and literary traditions, and this may be his most original contribution to Russian literature. 


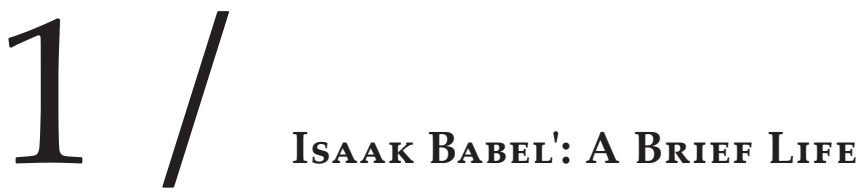

\section{Beginnings}

Neither Babel"s “Autobiography," written in 1924 to gain ideological credentials as a "Soviet" writer, nor the so-called autobiographical stories, which Babel' intended to collect under the title Story of My Dovecote (История моей голубятни) strictly relate to the facts, but they are illuminating for the construction of the writer's identity as someone who hid his highly individual personality behind the mask of a Soviet writer who had broken with his bourgeois Jewish past. Babel's father, for example, was not an impoverished shopkeeper, but a dealer in agricultural machinery, though not a particularly successful businessman. Emmanuel Itskovich, born in Belaia Tserkov', was a typical merchant who had worked his way up and set up his own business. ${ }^{1}$ Babel's mother, Fenia (neé Shvekhvel'), as Nathalie Babel has testified, was quite unlike the Rachel of the Childhood stories. About his book of Childhood stories, Story of My Dovecote, Babel' wrote his family: "The subjects of the stories are all taken from my childhood, but, of course, there is much that has been made up and changed. When the book is finished, it will be clear why I had to do all that." ${ }^{2}$ But then the fantasies of the untruthful boy in the story "In the Basement" ("В подвале") do inject a kind of poetic truth into the real lives of his crazy grandfather, a disgraced rabbi from Belaia Tserkov', and his drunken uncle Simon-Wolf.

Despite the necessary post-revolutionary revision of biography carried out by many writers, nothing could be more natural than Hebrew, the Bible, and Talmud being taught at home by a melamed, or part-time tutor. Babel', however, writes in his "Autobiography" 
as if this was purely at his father's insistence, as part of the pressure on the boy to learn a multitude of subjects from morning to night (Детство, 7). The Russian-Jewish journalist and future leader of the Zionist Revisionists, Vladimir (Zeev) Jabotinsky uses a similar expression in his biography, so it must have been pretty common for middle-class Odessa parents to try to instill some rudiments of Judaism and Hebrew in their sons, who did not always appreciate their parents' pressure to excel in their studies and enter the professions or become wealthy businessmen. Jabotinsky and Babel' found themselves among other Russian-speaking ethnic minorities at public school and could feel pride in their Jewish origins, yet at the same time identified with Russian culture, which was for many assimilated Jews the key to "culture" and social success. And yet with the reaction after 1881, the May Laws and pogroms, then increasing social unrest and violence in the early twentieth century, the choices facing Jews became starker, between revolutionary socialism and Zionism. The wealthy assimilated Jews described by Jabotinsky in The Five (Пятеро, 1936), which Charles King celebrates as the great Odessa novel, ${ }^{3}$ were "Russian in most senses except the one that came to matter most: the ability to negotiate their path through a society increasingly divided along national lines." ${ }^{4}$ Of course, Babel' matured after the 1905 Revolution and pogroms, when Jabotinsky (fourteen years his senior) was no longer living in Odessa and the world he describes was already in decline. ${ }^{5}$

The Five tells the story of a remarkable family, the Milgroms, whom the narrator befriends, and whom he observes during the 1905 Revolution. Jabotinsky's satire of the Jewish bourgeoisie, among whom he too moved as both a socialite and intellectual, records the decadence of the assimilated Jewish nouveaux-riches and their moral and spiritual deterioration as the revolutionary movements began to threaten law and order, spreading its ideas among the young generation who seem to be driven by an amoral determination to find an outlet for their energies, whether in adventures in promiscuity and crime or clandestine political and terrorist cells. ${ }^{6}$ What is remarkable in Jabotinsky's fictional account and in his autobiography, written from the ideological slant of emigration and commitment to revisionist Zionism, is the conscious 
self-identification as Jews, of proud ethnic rivalry, however Russified middle-class Jews were and despite their distance from Jewish tradition; yet they were also a world apart from the Jewish masses of Moldavanka and Peresyp'. This middle-class milieu (both Jewish and Russian), as Rochelle Sylvester has concluded from her study of the Odessa press in the 1910s, was fairly middle-brow and savored sensational reports of crime and prostitution, or melodramas and comedies about Jewish parents struggling with their wayward children's choice of marriage partner; they were not attracted to the literary clubs of the intellectual elite. ${ }^{7}$ Their children, by contrast, were often drawn to revolutionary and other socialist movements, as well as to Zionism, which had strong support (Babel' at one time belonged to a Zionist youth group). ${ }^{8}$

Babel' was forced to take up the violin, not too successfully, but perhaps not too unwillingly, with P. S. Stoliarsky (1871-1944)the prototype of Zagursky in "Awakening" ("Пробуждение"), though his parents hardly needed to "gamble" on his fortunes as a musician to drag themselves from poverty, like the brokers and shopkeepers in Babel"s story. Babel' had an unquenchable thirst for knowledge: he had to "know everything" in the words of his fictional grandmother in "Childhood. At Grandmother's" (“Детство. У бабушки"). The young Babel' would hide with his books under the dining-room table, where he would read for hours on end by the light of a cand-le, concealed by the long tablecloth. As for "resting" in school, which (according to the "Autobiography") was populated by an undisciplined crowd of overgrown billiard players, a classmate remembers Babel' outshining the history teacher in his answers, having at the age of thirteen or fourteen read all eleven volumes of Karamzin's History of the Russian State (История государства российского). The French teacher, a monsieur Vadon, whom Babel' singles out for mention in the "Autobiography," did get a number of pupils interested in French literature. In fact, Babel' would surreptitiously write his French assignments during the German lessons, occasionally letting out some unchecked exclamation which drew the shortsighted Herr Osetzky's attention and resulted in one of two rebukes: "Babyl [sic!], none of your stupid jokes" ("Babyl [sic], machen Sie keine faule Witzen!"), or 
"Are you quite crazy, Babyl?" ("Aber Babyl, sind Sie verrückt?") Babel' was often seen with books by Racine, Corneille, or Molière. The notebooks which date from this period attest to his copious reading-Anton Chekhov, the liberal short story writer, and Vasily Rozanov, a controversial philosopher of religion with bizarre views on the Jews as well as on gender and sex, the author of Solitaria (1912) and Fallen Leaves (1913-1915) - and there is an interesting mention of Walter Pater, the nineteenth-century English art historian. ${ }^{10}$ There is the usual schoolboyish essay on Pushkin folded neatly between the leaves of the notebooks. However, there is no trace of the stories in French that were mentioned in the "Autobiography."

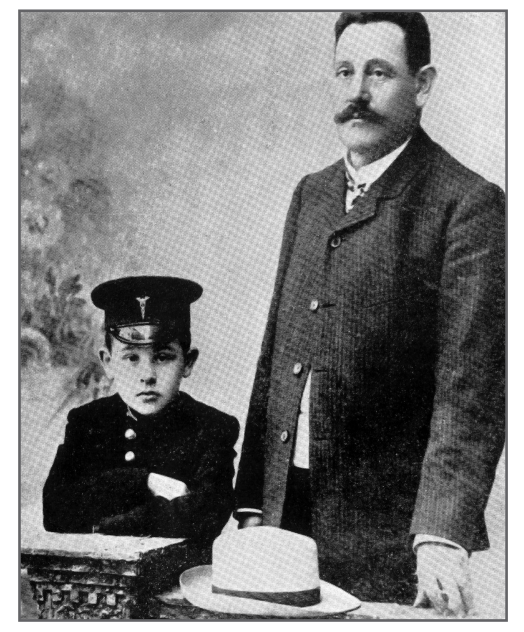

Babel' with his father, Nikolaev 1904

The first his school friends knew of Babel"s literary ambitions was a play which he read to them sometime between 1912 and 1914 on one of his visits home from Kiev. ${ }^{11}$ It was at this time that Babel"s first story known to us appeared, in 1913, in the Kiev journal, Ogni. The story “Old Shloime" ("Старый Шиойме") describes how, rather than see his son assimilate under social and economic pressure and convert, the senile Jew Shloime turns to the almost forgotten faith of his forefathers, and then to suicide. Babel"s literary debut must be seen in the light of his lifelong interest in the fate of Russian Jewry, here against the background of the Beilis blood libel trial that 


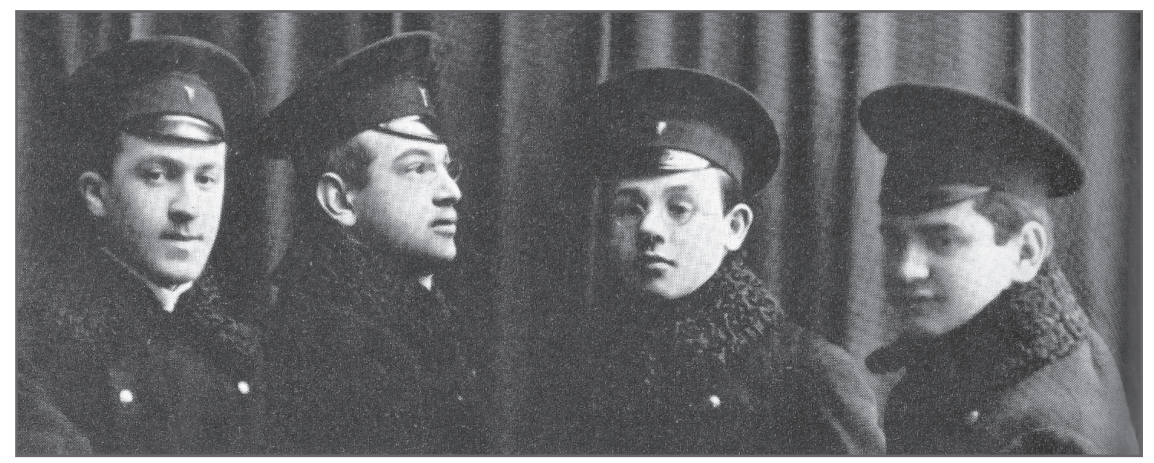

Babel' with his schoolmates

(left to right: A. Weintrub, A. Krakhmalnikov, I. Babel', I. Livshits)

opened in Kiev in 1911 and the expulsion of Jews from villages. It appeared in the context of debates over the "Jewish Question," and the anti-Jewish decrees would have lent poignancy to the story's closure, quite inexplicable to present-day readers, of Old Shloime's suicide. The corpse of the doddering senile old man sways outside the house where he had left a warm stove and "his father's greasestained Torah" ("засаленную отцовскую Тору") - the abandoned heritage of the older generation ("Torah" understood in the wider sense of Judaism and religious law) that was rejected together with their ethnic identity by the Russianized Jews who hoped for economic advancement and social acceptance (Детство, 14). The irony, of course, is that the filthy neglected old man's response to his son's apostasy is suicide, a transgressive act that has been read as a resistance to conversion and an affirmation of identity. ${ }^{12}$ The understated situation speaks louder than any pathos about the dilemma of the Jew torn between hope and apostasy, in a society which does not accept Jews even after they have abandoned the faith of their fathers. The background of evictions of Jews from villages following the Beilis trial is shared with Sholom Aleichem's final Tevye stories, but the outcome is different: faced by his sons' apostasy, Old Shloime turns to the Torah of his ancestors and commits suicide.

An undated and unfinished manuscript, written in prerevolutionary orthography, "Three O'Clock in the Afternoon" 
("Три часа дня"), deals with a Jew, Yankel, who tries to help his Russian landlord, Father Ivan, save his son, arrested for beating up a drunken peasant. This strange relationship between a Jew and an Orthodox priest affords Babel' a glimpse into the cruel and often absurd paradoxes of Russian Jewish life: the Russian needs the Jew for his entrepreneurial skills, his knowing ways with money, while the Jew takes a familial, irreverent view of things and takes care of his boss, ignoring anti-Semitic attitudes.

There is another correction we must make here to Babel"s official "autobiography." The "Autobiography" stresses Babel"s entire debt to Maksim Gor'ky, who was for many the gateway into literature, and tells how Babel' unsuccessfully peddled his manuscripts among various Russian magazine editors, although, as we have seen, his real début came about in very different circumstances. In fact, the two stories Gor'ky published (or rather the two that got past the censor) were among a number of sketches and stories Babel' published while in wartime Petrograd, some of them erotic. "Mamma, Rimma, and Alla" ("Мама, Римма и Алиа") and "El'ia Isaakovich i Margarita Prokof'evna" ("Элья Исаакович и Маргарита Прокофьевна") were published by Gor'ky in November 1916 in his literary magazine Letopis'. In the first story, a rundown Russian middle-class woman, trying to make ends meet during her husband's protracted absence, discovers her daughter trying to abort her illegitimate baby in the bathroom; in the other, Eli Hershkovich dodges the discriminatory residence laws by lodging overnight with a Russian prostitute, Margarita Prokof'evna, and the two strike up a convivial understanding and humane sympathy. The author was indicted for obscenity and incitement, presumably for the stories which appeared in Letopis', as well as possibly for a story about a voyeur in a brothel that was excised from the "Leaves from My Notebook" series, an early version of "Through the Fanlight" ("В щелочку"), which appeared after the February Revolution. As he joked in a later memoir, "The Beginning" ("Начало"), Babel' was saved from prison when the people rose in February 1917 and burnt his indictment as well as the court building.

The sketches and prose fiction Babel' published in Petrograd magazines in the years 1916-1918, under the pen-name "Bab-El'," 
include what amounts to his literary manifesto, "Odessa" ("Одесса", 1916). "Odessa" looks to a literary messiah from Odessa, a Russian Maupassant, and dismisses Gor'ky as not being a true "singer of the sun." The "Autobiography" is silent on this programmatic call for a rejuvenation of Russia's staid provincial literature with the influence of southern sunshine and conveniently glosses over Babel's descriptions of the horrors of revolutionary Petrograd in Gor'ky's Menshevik newspaper Novaia zhizn', which Lenin closed down in July 1918 for its scathing attacks on his regime. ${ }^{13}$ Moreover, any attention to Babel's absence from the events of the October Revolution is diverted by references to service on the Rumanian front (from which he was apparently evacuated in poor health), then passes on to his work in the Narkompros (Soviet education ministry) and Cheka (the revolutionary secret police), where, like so many intellectuals, he may have worked for a short time as a translator in return for the rations necessary for survival in the hungry years of War Communism, though Nathalie Babel, on the basis of what her mother told her, denies Babel' ever worked for the Cheka. ${ }^{14}$ Whether Babel' had actively served in the Cheka, and in what capacity, is ultimately a matter of speculation, fuelled by Babel"s detailed descriptions of Chekists in his stories "The Journey" ("Дорога") and "Froim Grach" (“Фроим Грач"), and his own repeated boast that he had worked for the Cheka. This may have been meant to endear him to the authorities in Moscow and enhance his mythical notoriety, especially when it was expedient after his return to Russia in 1928 to distance himself from the Russian émigrés in Paris. ${ }^{15}$

Despite the seven-year silence following the meeting with Gor'ky to which Babel' refers in the "Autobiography," he was busy penning further stories on erotic themes and experimenting in the "ornamentalist" style for the uncompleted series Petersburg 1918 (Петербург 1918) and Etchings (ОФорты). The formalist critic Viktor Shklovsky remembers Babel' in Petrograd in 1919 rewriting one and the same story about two Chinamen in a brothel, presumably "The Chinaman" ("Ходя"). "The Chinamen and the women changed. They got younger and they got older. Glass was broken, the woman was beaten up, then they got along and so on and so forth. It turned 
into many stories, not just one." ${ }^{16}$ Also in this period, Babel' wrote an aesthetic credo, the story "Line and Color" ("Линия и цвет"), which insists on artistic, not political vision, on the need for both line and color. Aleksandr Kerensky, the deposed Russian Prime Minister, whom the narrator meets in a Finnish sanatorium, prefers to see the world without spectacles, as an impressionistic picture of color, in which he can imagine whatever he wishes. The bespectacled Jew Trotsky (a reference later expurgated along with other references to Trotsky in Babel's work) ends the story with an uncompromising vision of the destiny of revolutionary Russia, of the clearly defined Party line. Thejuxtaposition of lineand color (which recalls the prewar debate in the journal Mir iskusstva $)^{17}$ relates to Babel's longstanding concern with the primacy of clarity of vision in art and truth over politics and falsity, touched on in a 1917 sketch, "Inspiration" ("Вдохновение"), which insists on diligent craftsmanship as a rule of thumb. Another story Babel' began during his stint writing for a Tbilisi newspaper in 1922, while recuperating with his young wife in the Caucasian mountains from his experiences on the SovietPolish front and chronic asthma, "My First Fee” ("Мой первый гонорар"), similarly addresses the narrator's initation into art, when he makes up a story about himself to a prostitute who rewards him with her own art of love.

The tension between the vision of the artist and the violent men of action is carried through much of Babel"s fiction. The parodied ineffectual Jewish intellectual who envies the men of action and stammers at his writing desk appears only briefly in the Odessa stories, which do not have a consistent authorial persona, but in the first edition of Red Cavalry (Конармия, 1926), the figure of Liutov, Babel"s fictional alter ego, plays as an ironical and ambiguous figure. ${ }^{18}$ It seems that Babel' was working at the same time on both the Odessa and the Red Cavalry stories in 1921-23. The Odessa stories began to appear in Odessa from 1921, beginning with "The King" ("Король") and "Justice in Parenthesis" ("Справедливость в скобках"). Although only four Odessa stories were included in the cycle in Soviet editions, nine stories have been published which clearly belong to the cycle, and one unsigned manuscript, "Esther's Ring" ("Кольцо Эсфири"), tells of an encounter in Odessa 
immediately following the Civil War, reminiscent of the style of the young Il'f. ${ }^{19}$

The Odessa tales look back to the banditry of pre-war and prerevolutionary days, when Odessa was in its heyday. There is no contradiction here between being a Jew in one's house and a man on the streets (in Yehudah-Leib Gordon's famous phrase, taken up by the maskilim). This empowered masculinity is something the Odessa Jewish gangsters have in common with the Cossacks in the Red Cavalry stories, with whom they share their raspberry waistcoats and muscularity. In both cases, the bespectacled Jewish intellectual finds it difficult to overcome Jewish scholasticism and impassivity. The Bolsheviks, however, had no poetic nostalgia for Odessa's past or for anarchy, and gradually the later Odessa tales become tinged by a note of sad regret for what has been eradicated in the name of the Soviet future. "The End of the Old Folk's Home" ("Конец богадельни") and "Froim Grach" relate the end of an ethos, the end of an era.

(a still from the film,

Benia Krik

Benia Krik, 1926)

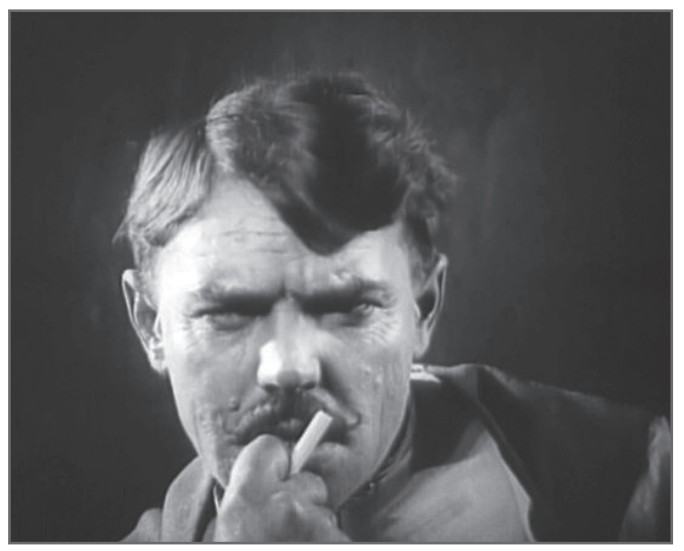

The 1926 movie script, Benia Krik (Беня Крик), ends with Benia being shot by the Reds during the Civil War, as was Moshe-Ya'akov Vinnitsky, a.k.a. Mishka Yaponchik, in real life. Of course, the model for Benia Krik, Mishka Yaponchik, was a nasty thug, a hardlabor convict, released in the February Revolution, who terrorized the Odessac/ bourgeoisie during the Civil War years, and there is little that is romantic in his story, despite the legends about this 
anarchist turned Robin Hood who is reputed to have said, "don't shoot in the air, don't leave witnesses." ${ }^{20}$ But in reverting to the prerevolutionary Odessa underworld heroes of Karmen's feuilletons or Yushkevich's stories and drama, Babel' seems to be projecting backwards in time a nostalgia for traditions and a way of life that are no more. However, he was also resisting an official discourse, according to which there was no place in a socialist Soviet society for underworld heroes, or, for that matter, for Jewish traditions. For obvious ideological reasons, the movie version of the Odessa stories, Benia Krik could only end with the victorious Bolsheviks eliminating the gangster leader, just as in real life Vinnitsky enlisted with the Bolsheviks who eventually ambushed and killed him. His funeral in Voznesensk, in July 1918, was attended by Minkovsky and the famous choir, just as, in a significant backshadowing of historical memory, Benia buries both the hapless Savka Butsis and Muginstein, with Minkovsky officiating and his choir in attendance in "How It Was Done in Odessa" ("Как это делалось в Одессе").

Another notable difference in the movie is that the defender of the Moldavanka masses is the Russian master baker, Sobkov, who organizes against their unfeeling exploiter Tartakovsky. Tartakovsky, the comical victim of Benia Krik's extortion in the stories, is presented in the movie as a bourgeois sympathetic to the Whites, thus spelling out the correct ideological line. The film also dispels any admiration for a Jewish gangster who defended the city's Jews against the Whites. Despite some lip-service to the cause of the proletariat, Vinnitsky's offer to join the Bolsheviks was entirely opportunistic, and in this respect, the Benia Krik of the 1927 film is closer to historical facts. The Bolsheviks' decision to eliminate the gangster leader after he attempted to desert with the battalion he had formed is transformed into a crude piece of propaganda and the movie closes with the new planned socialism sweeping away banditry and bourgeois exploitation through the endeavors of such proletarian leaders as the baker Sobkov.

The socialist future, however, is depicted at best as an ambivalent hope for a better world for the next generation in "KarlYankel" ("Карл-Янкель"), a story about the trial of a mohel (ritual circumciser). The "trials" of Judaism in the twenties had formed part 
of the repression of the traditional Jewish past; usually, there was less semblance of justice than in Babel"s story, and death sentences were handed out to those found guilty of religious practices. Anyone who opposed the will of the "people" in these proceedings was often arrested. In Babel"s story, the unfortunate babe is named for both the Jewish and Marxist patriarchs, an ambiguous fusion of destinies. ${ }^{21}$ Babel', however, does seem to have been willing to go along with Party propaganda, especially in his film work, which he undertook to accrue funds to support his family abroad and to buy time to write, but the subtle ironies of his stories, particularly in their un-excised versions, do not sit well with unquestioning obedience.

\section{A Jew on a Horse}

The genesis of Babel"s Red Cavalry stories goes back to his reflections on World War One. ${ }^{22}$ In 1920, four stories about war under the heading On the Field of Honor (На nоле чести) appeared in a short-lived Odessa magazine, Lava, edited by the communist journalist Sergei Ingulov and the poet Vladimir Narbut. Three of these were adapted from sketches of the Western Front by Gaston Vidal, whose ideals of patriotism and honor are turned into an ironic condemnation of the senseless cruelty of war. That summer, Babel"s insatiable curiosity and eagerness for journalistic experience resulted (with help from Ingulov) in credentials as a war correspondent for Iug-Rosta (the Southern section of the Soviet Russian Press Agency) attached to the ferocious First Horse Army, led by the legendary Semyon Budenny. After a one-thousand-kilometer march, Budenny's cavalry pushed the Poles out of the Ukraine and invaded large areas of Galicia and Volhynia, then still densely populated by Jews, among them many devout Hasidim. Babel' took a Russian pseudonym, Kirill Vasil'evich Liutov, under which he wrote for the front-line propaganda newspaper, Krasnyi kavalerist, but it was not easy to disguise his Jewish identity among the Cossacks. He recorded the dilemma of having to witness the maltreatment of the Jews with whom he was billeted, some of them victims of recent Polish pogroms, in a diary he wrote at the time. Witnessing the pillaging and rape by the Cossacks, Babel' pities the local Jews who have suffered at the hands 
of Poles and Whites, Ukrainians and partisan bands, and now are losing what little they have left to their Bolshevik liberators. While he was billeted with the Uchenik family in Zhitomir shortly after the town's occupation by the Reds, he tells them his mother was Jewish and tells them a story about a grandfather who was a rabbi in Belaia Tserkov' (perhaps a similar tale to the one the boy spins in the story "In the Basement"). ${ }^{23}$ Babel' defends the frightened Uchenik family against marauders, but on other occasions he remains silent as his comrades maltreat the local Jewish population, merely pouring balm on the Jewish inhabitants of the ruined shtetls and towns with fairy-tales of the Bolshevik utopia in Moscow.

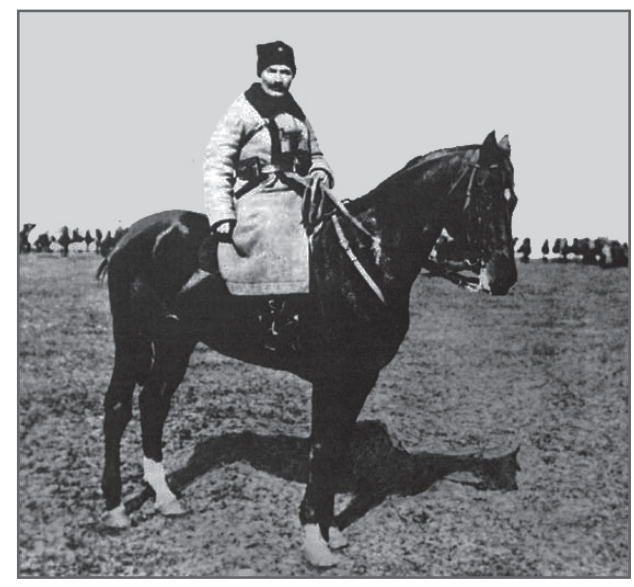

S. M. Budenny, 1920

After a few weeks working in headquarters, being conscripted as a paramedic and as a translator in the interrogation of prisoners of war, Babel' loses spirit and muses,
У меня тоска, надо все обдумать, и Галицию, и мировую войну, и собственную судьбу.

I feel anguished. I need to think about it all, Galicia, the world war, my own destiny. ${ }^{24}$

And a few lines further on he remarks, "I am alien, an outsider" ("Я чужой" [Собрание сочинений II, 264]), revealing his inner feelings of estrangement from the peasant and Cossack soldiers - an alienation that lies at the heart of the conflict of the fictional "Liutov." The 
Cossacks' bloodthirsty professionalism was impressive, but instead of revolution and justice, they brought looting and syphilis. At times Babel' grieves for the future of the Revolution (23-24 August), at others he despairs of the violence and anarchy visited on areas that have not recovered from the destruction of the First World War. At the end of August he witnesses the shooting of prisoners (the subject of "And There Were Nine" ["Их было девять"]), and by the Jewish New Year at the beginning of September, following the "Miracle on the Vistula," when the Bolsheviks were trudging in retreat through the rain-swept Galician mud, he is only too pleased to find a Jewish housewife willing to welcome him into her home. In a fragment of a letter written in August to his family, found between the pages of the diary, Babel' shows signs that he is sick of the war and does not see himself as an idealist:

\begin{abstract}
Я пережил здесь две недели полного отчаяния, это произошло от свирепой жестокости, не утихающей здесь ни на минуту, и от того, что я ясно понял, к[а]к непригоден я для дела разрушения, к[а]к трудно мне отрываться от старины, от того, ... что было м[ожет быть] худо, но дышало для меня поэзией, как улей медом, я ухожу теперь, ну что же,-одни будут делать революцию, а я буду, я буду петь то, что находится сбоку, что находится поглубже, я почувствовал, что смогу это сделать, и место будет для этого и время.
\end{abstract}

I have gone through two weeks of complete despair here, resulting from the savage cruelty which does not let up for a minute here, and from my clear realization of how unfit I am for the business of destruction, how difficult it is for me to break from the old ways [...] from what was perhaps bad, but which breathed of poetry for me like a beehive smells of honey, I will go away now, but so what, others will make the revolution, and I, I will sing what is to one side, what is deeper, I have felt that I will be able to do this, and there will be a time and place for this. ${ }^{25}$

The diary was clearly composed with a view to writing about the experience of the Polish campaign, with frequent memos to describe, draw portraits, and to record. An early draft of a story written in a realistic style about the Jewish shtetl Demidowka was composed on paper apparently torn from the diary (which may account for the 
missing pages in the manuscript), or an identical kind of journal, and indicates an earlier stage of composition, which suggests that only later Babel' came back to the diary and took material directly from his earlier impressions for a more modernistic treatment, distanced from his former self, as we will see in chapter 6 below. The drafts for the stories, written on narrow slips of paper some time after the war, suggest a larger work with a more conventional third-person narrator. ${ }^{26}$ They show that Babel' used only about half of the original plans, but little of what he discarded would have satisfied the critics' demand that he introduce communist heroes into the book. Nor would a more "positive" picture have been given by the stories excluded from Red Cavalry, "At Bat'ko Makhno's" ("У батьки нашего Махно"), a tale of a raped Jewish woman, "And There Were Nine" ("Их было девять"), an account of the shooting of prisoners, and "Grishchuk" ("Грищук"), about a returning Russian prisoner-of-war described elsewhere in Red Cavalry.

Nearly half of the Red Cavalry stories were printed in Odessa during 1923 in much the same form as they were later republished in Moscow, but by the time the first edition of Red Cavalry was published in 1926, Il'ia Bratslavsky's ideal of synthesis of Maimonides and Lenin, Hebrew poetry with communism, could be recognized as a delusion. The book ended with “The Rebbe's Son" (“Сын рабби”), which describes the death of Bratslavsky at a forgotten station and the narrator's identification with his idealistic dream. It was, however, by then impossible to speak openly about the tragic suffering of the Jews under both Poles and Bolsheviks, and much had to be hinted by inference or in the subtext. For example, the ordering of the chapters questions the justice of the killing and brutality carried out in the name of the revolution. In the opening story, "Crossing the Zbrucz" ("Переход через Збруч"), the narrator billets at the house of pogrom victims, unaware or pretending to be unaware of his own kinship with the suffering Jews. "Cemetery in Kozin” (“Кладбище в Козине") comes midway through the book and describes the graves of generations of unavenged Jewish victims of the Cossacks from Bogdan Khmel'nitsky to the present; it ends with a question that echoes the pregnant Jewess in "Crossing the Zbrucz": why has 


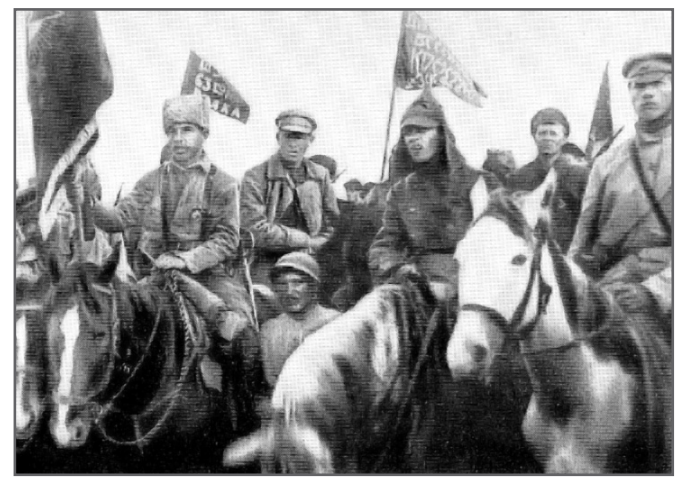

the Angel of Death not spared the Jews? There is no answer, but it cannot escape our attention that "Cemetery in Kozin" is sandwiched between two stories of particularly vicious revenge carried out by Cossacks, who, unlike the Jews, can seek retribution for the wrongs done to them. ${ }^{27}$ At the time, Babel' had published, among his pieces in the front-line propaganda newspaper Krasnyi kavalerist, descriptions of anti-Semitic atrocities, and exhorted the Cossacks to beat the perpetrators, albeit in politically correct language, ${ }^{28}$ the antiSemitism rife in Red Cavalry units should have disabused Babel' of the hope of sympathy from his comrades for the plight of the Jews. Some Red Cossacks, including members of the Sixth Division of the First Horse Army, which figures prominently in Red Cavalry, also participated in pogroms; for example, during the retreat from Poland in September 1920. The sixth division was disarmed and decommissioned, and a special tribunal sentenced the perpetrators to severe punishment; the commanders Kniga and Apanasenko (the fictional Pavlichenko) were given the death sentence, but this was commuted to fifteen years of hard labor and demotion. In August 1920, Vardin, the head of the Political Section of the First Horse Army, had written in a report that Budenny's troops, three quarters of whom were peasants and Cossacks, were only prejudiced and disliked Jews but were not anti-Semitic. However, the pogroms, which were not confined to the sixth division, indicated the extent of anti-Semitic violence among Bolshevik troops, who at one point took up their ideological enemies' cry of "Save Russia, Beat the Jews and Commissars." 29 
The diary formed the basis for the Red Cavalry stories which tell of the inner conflict of the Jewish intellectual "Liutov" caught between the messianic ideals of socialism and the violence of revolution, between his severed roots in the Jewish traditions of a decaying world and the hostility of the anti-Semitic Cossacks, who despise him for his intellectual humanism. ${ }^{30}$ "The Rebbe's Son" ends with the death of Liutov's soul brother in and the defeat of Soviet forces, reflecting Liutov's despair at realizing the ideals of the October Revolution and his failure to become a man of action. In 1933, Babel' added "Argamak" ("Аргамак") as the new ending of Red Cavalry, closing the dialectic with Liutov's acceptance by the Cossacks, though not before he makes more enemies. He has learnt to ride with the Cossacks, but he has not necessarily conquered his humanistic revulsion at killing, as we see at the end of "The Death of Dolgushov" ("Смерть Долгушова"). A further story, "The Kiss" ("Поцелуй"), appeared in 1937, offering a possible new but no less ambivalent ending (never adopted by Babel' himself) which would have brought the cycle full circle with the Soviet withdrawal over the old Polish border, but also brings to an a end the love story and the Tomlins' hope of moving to the Bolshevik utopia in Moscow.

\section{The Rise and Fall of Babel'}

The second half of the 1920s saw recognition of Babel' as one of the most talented young writers in Soviet literature, and at the same time saw his denigration, along with other fellow-travelers, as undesirable in the new society. The publication of Red Cavalry stories in Moscow journals in 1924 earned the rebuke of the legendary commander of the First Horse Army, Budenny himself, in an article whose title is roughly translatable as "Babel"s Bawdy Babbling" ("Бабизм Бабеля"). Budenny and his First Horse Army had become legendary both in a revisionist historiography of the October Revolution and in popular literature. ${ }^{31}$ His name was useful to the militant campaign of the Proletkul't and the critics around the left-wing journal $\mathrm{Na}$ postu out for the blood of the fellow travelers. As they put it in their manifesto in the first issue of Na postu: 
We shall stand firmly on guard over a strong and clear communist ideology in proletarian literature. In view of the revival ever since the beginning of NEP of the activity of bourgeois literary groups, all ideological doubts are absolutely inadmissible, and we shall make a point of bringing them to light.

The "October" group, which had broken away from the mainstream proletarian writers, the "Smithy," was intolerant of the "fellow travelers" and rigorously condemned any attempt to express an artistic view that was at all equivocal about the Bolshevik Revolution.

From the tribune of the journal Oktiabr', Budenny attacked as slanderous Babel"s description of the First Horse Army. To give an acceptable picture, Budenny thundered, the author had to be a Marxist and show the dialectic of the class struggle. Babel' is here dubbed "citizen," rather than "comrade," and is portrayed as a White Guard bourgeois who is "by nature" ideologically hostile. The great general accused Babel' of:

telling old wives' tales, fumbling in old women's second-hand underwear and narrating in a horror-stricken old woman's voice how a hungry Red Army soldier took a chicken and loaf of bread; he invents things that never happened and throws dirt at the best Communist commanders. He fantasizes and simply lies.

An editorial note described Budenny's attack as "valuable" and promised to follow it up with a discussion of the whole question of Babel's work - this before Babel' had published a single book!

Naturally, Budenny would have been incensed to read descriptions of army commanders, including himself, using force and threats to lead an undisciplined band of men on a rampage with no clear ideological or military direction. The mock rape of Sashka during the Cossacks' desecration of St. Valentine's Church (toned down in the first edition of Red Cavalry), the details concerning lack of ammunition and provisions, and the depiction of ignorant, semi-educated Cossacks could not have pleased the man who had led a Cossack army one thousand kilometers to fight the enemies of Bolshevism and who was later to become a Marshal of the Soviet Union. Budenny had sided with Stalin against Trotsky and Tukhachevsky and he was interested in deflecting from Stalin 
any possible responsibility for the rout that ended in Polish victory. The warm humanitarianism of the Jewish intellectual, torn between his roots in the dying Jewish past and a violent revolution, could only give an ethnic and ethical perspective offensive to Budenny's position and feelings of national pride. ${ }^{34}$

Budenny's sortie reinforced the attacks of Oktiabr' on fiction, including Babel"s stories, which had been published in the leading literary journal Krasnaia nov'. These attacks directly targeted its editor Aleksandr Voronsky, an Old Bolshevik who was the object of a long drawn-out polemic that was to end in 1927 with his expulsion from the Party, a sick and broken man, and his exile to Lipetsk. He would ultimately fall victim to the Purges. Babel', who did not side with any camp and was grouped by critics with the fellowtravelers, was further compromised because he had published his Odessa and Red Cavalry stories in Maiakovsky's LEF, the journal of the Futurist Left Front of the Arts, whose position was also under fire from Oktiabr' and the orthodox Marxist critics. ${ }^{35}$

In his reply to Budenny, ${ }^{36}$ Babel' affirmed the truth of what he had depicted in fictional form by citing a letter from S. Mel'nikov, one of the heroes of the Red Cavalry story, "Story of a Horse" ("История одной лошади"), originally entitled "Timoshenko and Mel'nikov" (“Тимошенко и Мельников"). Babel' guilelessly apologized for leaving the real names of his heroes unchanged and, in fact, he did alter several of them for the full publication of the cycle. ${ }^{37}$ In preparing the first edition of Red Cavalry for publication, Babel' told his editor at the State Publishing House, Dmitri Furmanov, author of the Civil War epic, Chapaev (Yanaeb), and a leading activist in RAPP, the Proletarian Writers' organization, that he had acceded to requests for changes, but at the same time naively declared he did not know how to replace "risky passages." ${ }^{38}$ Babel"s astounding assurance that nobody would take them to task for leaving unchanged those parts which had come in for criticism belies Babel"s determination to resist political censorship-in a letter of 16 November 1925 to his sister, Babel' declared he had held up publication of Red Cavalry because be refused to accept certain deletions. ${ }^{39}$

The mood in Moscow in the middle of the decade was turning from relative freedom to heated ideological debate. Lenin died in 
Babel' in a humorous photo published alongside Budenny doing gymnastics (1933)

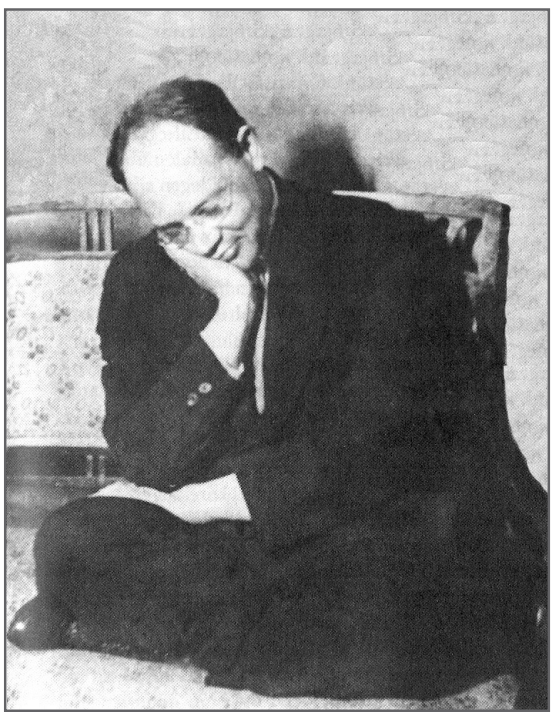

1924, succeeded by Stalin. A short piece about a mutiny on board a foreign ship, "You Missed the Boat, Captain!" (“Ты проморгал, капитан!"), dated the day of Lenin's funeral, used stylistic contrasts to make a political point, but it was flimsy stuff, and Babel' did nothing to mitigate the ambiguity of the narratorial position in the Red Cavalry stories. The literary journals reverberated with the polemic over whether political correctness and an uncritical portrayal of the Bolshevik Revolution should be the sole yardsticks by which writers were to be judged, and in December 1924 the Red Cavalry stories were subjected to a public debate arranged by the Moscow daily, Vecherniaia Moskva. Vladimir Veshnev, writing in Molodaia gvardiia, complained that Babel' and other fellow travelers subjected the October Revolution to their moral judgment, rather than the other way around. Veshnev clearly saw the result of this independence of conscience and insistence on the writer's freedom in Babel"s poeticized portrayal of the Odessa gangsters and Cossacks. ${ }^{40}$ Similarly, the critic Georgii Gorbachev, while comparing Babel' to Heine and praising his innovative contribution to Russian literature, nevertheless asserted that Babel"s romanticism was unacceptable in the current revolutionary times. He called Babel' a cynical aesthete who had backed the Reds and not the Whites 
for reasons of his own. ${ }^{41}$ The attempts of less literal-minded critics to plead that Babel' used artistic devices to penetrate inner truths and that the view of the alienated intellectual Liutov could no more be taken as an ideological statement than the views of the Cossacks in the skaz stories only irritated those critics who had no time for humanitarian intellectuals. ${ }^{42}$ No wonder Gor'ky complained that Babel' had been misread and misunderstood. $^{43}$

Despite the fame and notoriety he had earned as a result of the Red Cavalry and Odessa stories, Babel' was repelled by the low literary standards, the vulgar materialism, and the growing constraints on creative freedom, and he avoided literary circles. In a letter of 12 May 1925 to his sister abroad, he outspokenly complained of "seething in a sickening professional environment devoid of art or creative freedom.." ${ }^{44}$ The fellow travelers were under attack, and Babel"s was one of the signatories who petitioned the Central Committee for a halt to the campaign against them. A 1925 Party decree, however, declared neutrality on the literary front and the hysterical campaign against the fellow travelers grew stronger when RAPP, the proletarian faction, gained the upper hand by the end of the decade. Although Babel' might fit into Civil War fiction, such as Fadeev's The Rout, or depictions of the underworld in Leonov's The Thief (Bop, 1927), he really stands out as a dissonant voice by the end of NEP, when writers were expected to enlist their pens to the construction of socialism.

\section{Return to an Odessa Jewish Childhood}

Contrary to expectations of the ideological diehards demanding that writers focus on the October Revolution and the building of socialism, Babel' went back to an Odessa childhood and traced the life of a Jewish intellectual before and after October 1917. This was a series of stories entitled Story of My Dovecote (История моей голублтни) that took the Odessa Jewish narrator through artistic awareness, in "Awakening" and "Di Grasso" ("Ди Грассо"), and literary apprenticeship, in "Guy de Maupassant" ("Гюи де Мопассан"), to the October Revolution in "The Journey". Although 
the story was begun in the early twenties, the ideological pressure of Stalin's dictatorship tells in the formulaic ending of "The Journey" (a revised version of "Evening at the Empress's" ["Beчep у императрицы"]), when the narrator reaches the goal of his arduous journey (a journey that is an education in anti-Semitism rather than ideology) and joins the Cheka, enjoying camaraderie and happiness. However, "The Journey" does not pass over the irony of a formerly persecuted Jew trying on the robes of the Russian royal family. Newly enfranchised and empowered, the Jewish victim turned victor can literally put on the authority of his former tormentors.

Beginning with "Story of my Dovecote" ("История моей голубятни") and "First Love" ("Первая пюбовь"), Story of my Dovecote would not have pleased ideologues demanding stories of contemporary Russia, for not only does it return to the prerevolutionary past without the correct political revision of history, but it revisits Jewish cultural identity with the hindsight of Civil War pogroms. Essentially, Babel' revisits the topos of a Jewish childhood in Modern Hebrew and Yiddish literature, in which the patriarchal family and traditional schooling in the kheder hem in the child who wishes to break out into the Gentile world of nature and secular culture. ${ }^{45}$ In the autobiographies and memoirs of Babel"s generation "culture" is invariably Russian culture, the culture of Pushkin, Dostoevsky, and Tolstoy, and it is identified with modernity and revolution. Not for nothing does Yuri Slezkine entitle his collective portrait of the revolutionary generation "Babel"s First Love." 46

Babel"s fictional memoir of a Jewish childhood in Odessa actually began with his 1915 sketch "Childhood. At Grandmother's" (“Детство. У бабушки"), which demonstrates the violent contradiction between the intense, stifling atmosphere of the closed Jewish world and the entirely alien Russia of Turgenev's First Love (Первая любовъ). The passionate sensuality and cruel violence of Turgenev's fictional world intrudes into the Jewish home when Vladimir's father strikes Zinaida on the bare arm with his horsewhip (in chapter 21) and the hidden side of human love is revealed to the watching boy. ${ }^{47}$ 
Я слышая свист хлыста, его гибкое кожаное тело остро, больно, мгновенно впивалось в меня. Меня охватывало неизъяснимое волнение. На этом месте я должен был бросить чтение, пройтись по комнате. ... Темнеющая комната, желтые глаза бабушки, ее фигурка, закутанная в шаль, скрюченная и молчащая в углу, жаркий воздух, закрытая дверь, и удар хлыстом, и этот пронзительный свист - только теперь я понимаю, как это было странно, как много означало для меня. (Детство, 31-32)

I heard the whistle of the whip, the supple leather dug into me keenly, painfully, instantaneously. I was siezed by an inexplicable excitement. At that point I had to stop reading, walk about the room. ... The darkening room, Grandmother's yellow eyes, her small figure wrapped in a shawl, doubled up and silent in the corner, the hot air, the closed door, and the smack of the whip and that penetrating whistle-only now do I understand how strange it was, how much it meant to me. (Red Cavalry and Other Stories, 24)

The boy feels the pain of the whip cutting into him, transferring the victim status from the mistress to the Jewish boy, and, stifled by the heat in the close, darkening room, he is at once transfixed to the spot by this extraordinary sensation and wishes more than anything to flee and never return. The Grandmother cannot understand any of this - she does not read Russian and hopes the boy will become a bogatyr (folk-hero), probably because she is thinking of the Yiddish gvir (a rich man). She goads the boy on to "know everything," because, although illiterate herself, she knows this is the key to social mobility and success. The boy is deeply affected by the erotic power of his reading, unconsciously internalizing the real violence of pogroms and persecution, but also projecting the impotence and passivity of the imprisoning, suffocating mental ghetto in the middle-class Jewish home that demanded intellectual or business acumen, not physical attainment.

Performance of a literary text suggests a cultural identification that was common among upwardly mobile, acculturated Russian Jews. The performance of a literary text can become almost a kind of initiation or test of cultural identity, typically of verse by the Russian national poet Pushkin. ${ }^{48}$ It is Pushkin's poetry that the 
boy recites deliriously during the history exam in "Story of My Dovecote," and this passionate frenzy earns the coveted place in the gimnaziia (lyceum high school), where entry to Jews is restricted. However, acceptance does not come easily. The boy's entry to the gimnaziia is celebrated as a Jewish victory, like David's over Goliath; but the doves which the boy has earned through his achievement of overcoming the numerus clausus are snatched away from him by the cripple Makarenko during the pogrom. We cannot help noticing that Makarenko's hand is stained with leprosy, and doves were an ancient cure for the disease. The dove is, of course, a sacrificial bird in the Temple ritual prescribed in the Hebrew bible, and when the bird's innards are crushed against the boy's face he undergoes a rite de passage that opens his eyes to the cruel adult world of violence and anti-Semitism. Katerina, the cripple's wife, fulminates against Jewish men and their stinking seed, so that the boy's initiation is also an awakening to his maligned sexuality as a circumcised Jew. As if to emphasize the hostile stereotype of the emasculated Jew, his uncle Shoyl, who trades on Fish Street, is found murdered with a fish stuffed in his mouth and another sticking out of his pants (one thinks also of the dying Il'ia Bratslavsky with his pants down, whose emasculated sexual organs attract the stares of Red Army women).

In dedicating "Story of My Dovecote" to Gor'ky, the patron of Russian writers and a defender of the Jews in the Tsarist period, Babel' is resolving the contradiction between the desired identity of a budding Russian writer and the reality of pogroms in which, as a Jew, he is himself the victim. As Babel' reportedly told Paustovsky:

-Я не выбирал себе национальности. ... Я еврей, жид. Временами мне кажется, что я могу понять все. Но одного я никогда не пойму-причину той черной подлости, которую так скучно зовут антисемитизмом. ${ }^{49}$

"I did not choose my ethnic origins. ... I am a Jew, a Yid. At times I think I can understand everything. But one thing I will never understand and that's the reason for that filthy treachery which goes by the humdrum name of anti-Semitism." 
And, indeed, only after we have understood what anti-Semitic violence means to a bewildered Jewish boy, "Story of My Dovecote" ends with that trite, well-worn word, pogrom.

We may well ask how such experience of anti-Semitism fits in with an aspiration for Russian cultural identity. In "First Love," which was intended to be published together with "Story of My Dovecote,"50 we follow the events of the pogrom in Nikolaev and its aftermath through the same text the boy read to his grandmother in "Childhood. At Grandmother's." The title refers ironically to Turgenev's novella, and the boy again confronts the violent sensuality of Turgenev's Russian world, this time in his own infatuation for Galina Apollonovna Rubtsova, the Russian officer's wife who shelters the family during the pogrom. To win her love in his imagination, he fantasizes he is in the Jewish self-defense bands, like Miron the coal merchant's son, armed with a rifle, fighting the marauders in a pogrom. His own Jewish body, however, is weak and neurotic; he gets migraines from studying so much. Although he is contaminated and befouled by the innards of the dead bird dripping down him, Galina washes him, then kisses him full on the lips, and promises her "little rabbi" he will be a bridegroom (reminding us ironically of Lopakhin in The Cherry Orchard recalling his childhood memory). The sexual fantasy of a Russian woman projects the self-debasement in the boy's perception of his Jewishness and acts out the tensions between the impassive heroism of the Cossacks riding into an imaginary gorge and the degradation of his own father kneeling in the mud (in contrast to the strength and horsemanship of the boy's father in Turgenev's novella). ${ }^{51}$ The traumatic events of the day have prematurely turned him from an uncomprehending boy into an awkward adolescent afloat in his own vomit, which he retches unashamedly in front of Galina, straining to hold on to his fantasized power over this exotic woman in Chinese silks. The boy's introduction into adulthood has been a deeply Jewish experience of violence that is bound up with the attraction of Gentile power and sexuality. The erotic power of menacing violence can be seen in the boy's infatuation with the forbidden, sexualized object of desire, while his father grovels in the mud, debasing himself before a Cossack horseman, and his own 
portrait (his Jewish self) is thrown out of the looted shop. The boy can, it seems, only will himself into manhood if he can overcome his Jewish lack of masculinity. In Galina's gaze at her husband, who has returned from the Russo-Japanese war, the boy discovers a shameful knowledge of sexuality. The knowledge renders him speechless and brings on hiccups - a female and Jewish disease, we are told in the uncensored ending, which ascribes the origin of the narrator's early waning to anti-Semitic violence (Детство, 57). ${ }^{52}$ Speechlessness is also a hindrance to acquiring the Russian tongue (just as Mandelstam in The Noise of Time saw the Jewish chaos as a space of non-glossia, or tonguelessness). The paradoxical coupling and alternation of Russian and Jewish identities, which constantly fascinated Babel', concealed below the surface a conflicted self, ashamed of Jewish physical and social inferiority. ${ }^{53}$ It should not, then, be surprising that the empowered masculinity of the Cossacks in Red Cavalry is shared by the Odessa gangsters. By contast with the bespectacled intellectual stammering at his desk, as AryeLeib tells the narrator in the Odessa story, "How It Was Done in Odessa," Benia Krik is a man of action who knows what to do, who can sleep with a Russian woman and satisfy her. This perception of Jewish emasculation can be historicized in the post-revolutionary perspective of those Jews who had invested their hopes in a new social order and in an ideology that promised both social justice and liberation from "Jewish fate."

The previous generation had converted to socialism through learning Russian and discovering science and literature, but in "Awakening," the boy's "awakening" is to nature and to his shame at the weakness of his Jewish body. This is a hopeless struggle between the Jewish heritage-hysterical pressure to study and become famous - and the sea, where urchins run around naked all day long. Smolich, who takes in the Jewish weaklings from the fleapits of Moldavanka, is the bronzed god who introduces the boy to the beauty of Russian nature. For, in order to become a Russian writer, he must face the contradictions between the onion-reeking Jewish fate of his family and the literary example of Turgenev and Dumas (whom he has been illicitly reading behind his music score). But then, he is a dreamy, deceitful boy who will never overcome 
the hydrophobia of Frankfurt rabbis and Jewish neuroses. The boy's father, unfortunately, is gripped by the delusion of wealth and social status barred to Jews and has staked everything (in the opening metaphor of the story) on the boy's virtuosity to break out of the desperate poverty and bloody persecution of a Jewish family in Russia.

\section{To Starve or to Be Strangled?}

While Babel' was struggling to establish himself as a writer in Moscow, his family life was falling apart. After the death of his father in March 1924, Babel' was burdened by his family responsibilities, which made it more difficult still to concentrate on writing. He was separated from his closest family when his sister Meri emigrated with her husband Grigori Shaposhnikov to Belgium in February 1925, followed by his mother, who joined them the following July after it became clear that Meri was reluctant to come back to Russia-a trip for which she had, in any case, become too ill. Babel"s wife Evgeniia (Zhenia), an artist, left for Paris alone in the summer of 1925, although Babel' had originally planned for them to leave together. Babel"s departure abroad was delayed by the death of his father-in-law, which required his presence in Kiev to settle complicated legal matters. It was decided that Babel' would take with him Zhenia's mother Berta Davidovna, who had progressed from one extreme of coolness to another extreme of adoration for her famous son-in-law. However, the year which Babel' spent abroad in 1927-1928 presented no solution to either his creative or family problems. Hopes were thwarted that Zhenia's brother Lev, a wealthy businessman in the United States, would come and take the old woman off their hands, so she remained a burden that drained their financial and emotional resources. To make matters worse, Zhenia did not have a stable income from her painting to support all of them. In his repeated entreaties to have his family rejoin him in Russia, Babel' was probably right when he assured them that the material conditions of life-medical care, housing, food - were better than what they could afford in Europe, especially after the 1929 Wall Street crash and the ensuing Depression. But 
then he held a privileged position and had access to luxuries of life denied the ordinary Soviet citizen. To be sure, the rubles he earned in the Soviet Union were drops in the ocean when spent on necessities in Brussels and Paris, and this made the struggle to raise money and somehow get it abroad stressful and at times futile.

Babel' and his sister Meri in Belgium

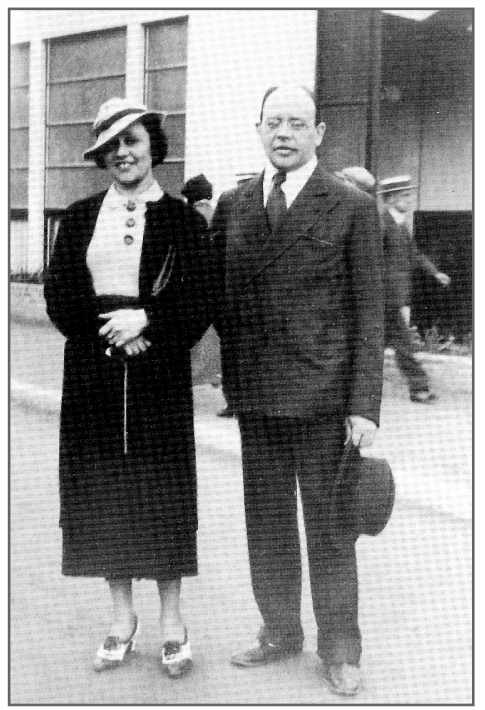

It turned out that working conditions in the capitalist West were no more conducive to Babel's laboriously slow methods of composition than the ideological pressures of Soviet editors and critics. Negotiations with American theaters came to nothing, and the only project we know he was engaged in with a foreign company, during his second visit to Paris in 1932-33, also failed. This was a film script on the life of the terrorist and double-agent Evno Azef, undertaken for the director Aleksei Granovsky (with whom Babel' had worked on the 1925 movie of Sholom Aleichem's Menakhem Mendel stories, Jewish Luck [Еврейское счастье]), but someone else offered the film company a completed script and, besides, working with political émigrés was not advisable for a Soviet citizen wishing to return to Russia with an untarnished reputation. Babel's correspondence reveals his failure to establish himself as an independent professional writer abroad like Vladimir Nabokov. In remarks made to a Soviet audience in 1933, Babel' 
expressed his view of the pitiful vacuity and poverty of émigré life and, although he singled out Nabokov as one of the few successful Russian writers, he did not find anything in Nabokov's prose that spoke to him. ${ }^{54}$ The series of Paris stories Babel' wrote, of which we have two, "Rue Dante" (“У дица Данте," published 1934) and “The Trial" ("Суд," published 1938), are of more interest as vignettes on erotic themes and will be discussed in chapter five. Babel' seems not to have been active in Russian émigré life. His Russian publications abroad in the twenties were limited to editions of stories published in Moscow (though French translations of his work did appear); in the 1930s, Babel' seems to have confined himself to arranging for the translation of French writers into Russian for publication in Moscow.

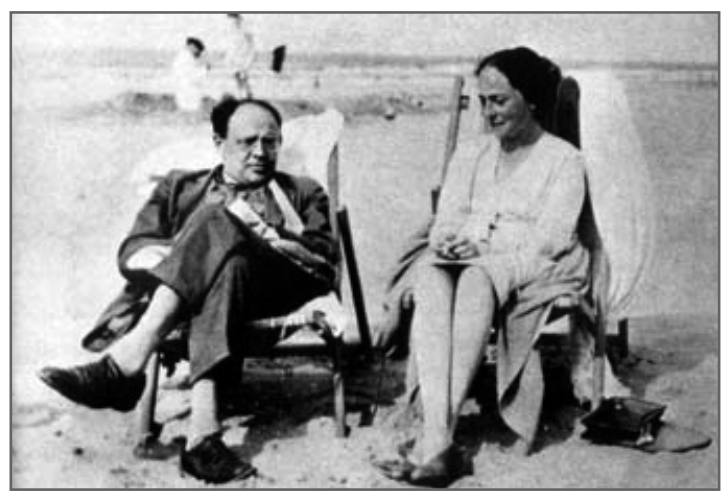

Babel' and Zhenia, Idelsbad, Belgium (1928)

Unlike countless Russian émigrés, Babel' could never have resigned himself to working as a Paris taxi driver or selling haberdashery, and he seems to have been in debt, at times penniless, and dependent on income from royalties in Soviet Russia. He appreciated the personal liberty offered by the West, but Paris, for all its gaiety, had become provincial, it had none of the breadth of ideas he was used to in Russia. ${ }^{55}$ When Babel' returned to Russia in the fall of 1928 to settle Zhenia's inheritance and other disordered affairs, he declared that he had felt as if he had not been totally himself in Paris. He was quite willing to take a trip abroad, he wrote, but he had to work in Russia. In Russia there was "poverty, much that is sad, but it is my material, my language, something that is of 
direct interest to me.."56 Letters in the following years speak of the incredible interest which the enormous changes in the Soviet Union held for him, and, even after taking into account the fact that letters abroad were written with the censor in mind, there is no mistaking a sincere enthusiasm for the new society that was taking shape and replacing the feudal Russia of the Tsars, where the Jew could never have been an equal citizen. Babel"s exhausting trips in the following months and years to collective farms, factories in Dniepropetrovsk, Jewish colonies, and (despite his chronic asthma) mines were surely no mere lip-service to the call for writers to enlist in the building of socialism, but a sincere effort to understand the astounding transformation of Russian society, as well as the terrible price being paid for it. Unfortunately, the time was coming when loyalty to the Party was expected to be total, and writers could no longer publish abroad or divide their lives between Paris and Moscow. The privileges of a Soviet writer were bought at the price of personal choices. Gradually, conformity required increasing compromises.

Babel' and Nathalie

(1933)

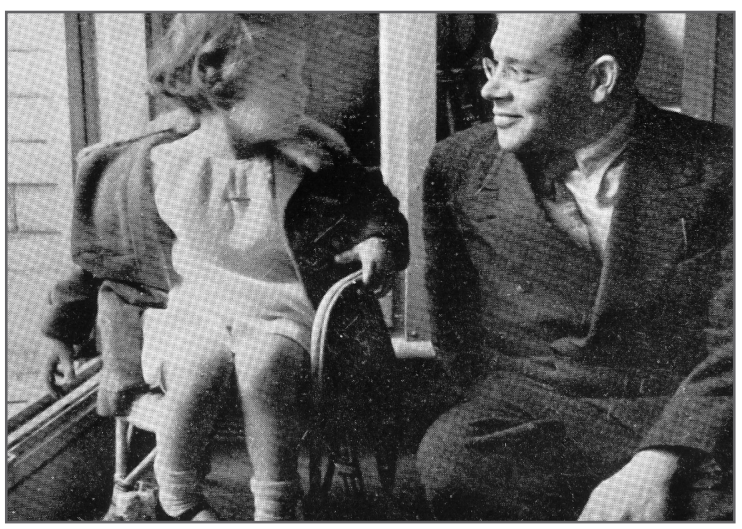

In July 1929, Zhenia bore a daughter, Nathalie, whom Babel' had wished to call by the more Jewish name of Judith, and the existence of this "Makhno," as Babel' dubbed his precocious offspring, was a further incentive to try and reunite his family in Russia. ${ }^{57}$ In order to persuade his family to rejoin him in Russia, Babel' assured them that he was ready to settle down to family life and that the past 
was finished with; a reference to a relationship he had in Moscow from April 1925 with the Russian actress Tamara Vladimirovna Kashirina, who had a son by him, Mikhail, later adopted by the man Kashirina was to marry in 1929, the well-known writer Vsevolod Ivanov. $^{58}$

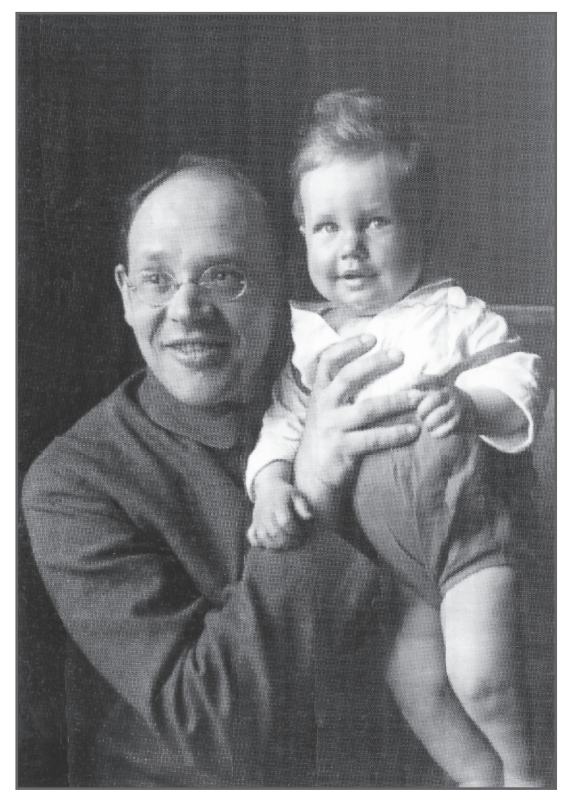

Babel' and son, Mikhail

A further trip abroad in 1932-1933 did not manage to reunite the family, and Babel' complained in the letters to his family that the emotional strain of separation, not to mention his mother's and sister's constant state of anxiety, affected his work and his nerves. This desire for stability and the perennial need for peace of mind in order to write were, without a doubt, motives in his decision to start a new family. In 1932, Babel' met an engineer on the Moscow subway construction project, Antonina Nikolaevna Pirozhkova, and in 1934 he settled down with her. A daughter, Lydia, was born to them in 1937. Curiously, there is no reference to them in his published letters to his family abroad, and when he went to visit his Jewish relatives in Odessa, he went alone. ${ }^{59}$ The compartmentalization of his life makes the enigma of Babel' all the more intriguing. He himself liked to introduce Antonina Nikolaevna rather piquantly-and 
utterly fictitiously - as the daughter of a Siberian priest. It was not that intermarriage was at all uncommon (and the couple welcomed many well-known Jewish cultural figures to their home), but Babel' was simply amused by the idea of a Jew and a priest's daughter living together. ${ }^{60}$

The time he spent on a stud farm at Khrenovoe in Voronezh Province during the summer of 1926 and the spring of 1929, or in the village of Molodenovo, thirty miles from Moscow, in 1930-1932, taught Babel' that only peace and quiet, with freedom from financial and emotional anxieties, could enable him to concentrate on his writing. The breathtaking natural landscape had won Molodenovo the reputation of a Russian Switzerland, and it was in this pastoral setting that Babel' could recuperate from the distraction and hassle of Moscow. Molodenovo was an ideal hideout, not easily reached during winter snowstorms or spring flooding, yet it was still within reach of his Aunt Katia's parcels of victuals and other good

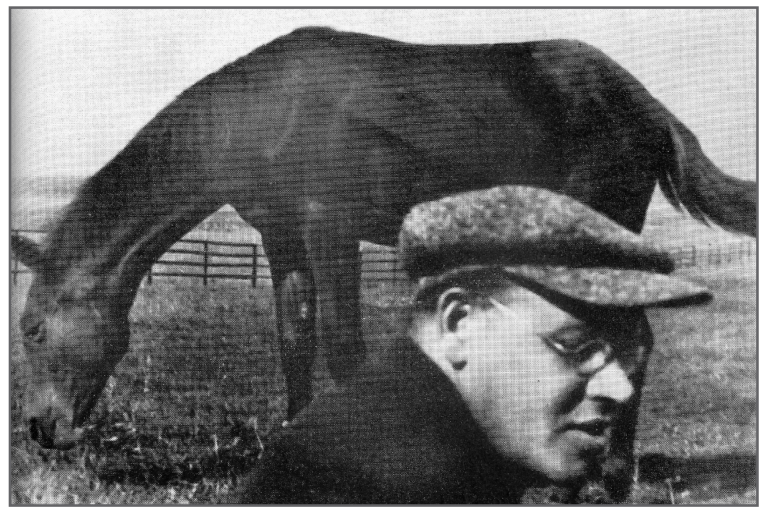

Molodenovo, 1931

things. When the rivers were not in flood, Babel' could easily spend a few days in Moscow offices to get official approval for transfer of foreign currency or advances from editors. Molodenovo was also convenient because Gor'ky had a house there, and thus was Babel"s neighbor.

Babel"s frustration at the difficulties of becoming a fully independent professional writer was intensified by the need to do hack work and to bargain with editors for advances on stories that he had not completed or were unpublishable. He had to maintain 
ideologically correct behavior in order to get permission to travel abroad, as well as money to make a living and to send to his family. Coupled with his asthmatic ailments and expensive dental treatment, this impeded progress with his writing and confined him to what became a characteristic treadmill, from which he never seemed to escape because he refused to mass-produce material on demand or give up on his painstaking craftsmanship. To V. P. Polonsky, the editor of Novyi mir, he wrote: "despite my disordered personal affairs, I will not change by one iota the system of work I have adopted and will not forcefully and artificially hasten it by one hour." ${ }^{\prime 61}$ It did not help that Babel"s disastrous generosity made him the easy prey of relatives in distress, whose importunate entreaties for assistance hampered his work and diverted essential financial resources.

In the meantime, Babel' developed a flair for drama. Written in 1925-26, during the height of his affair with Tamara Kashirina, his play about the fall of Mendel Krik and the rise of his son Benia, Sunset (3akam, 1928), allegorizes the sunset of Russian Jewry, which cannot resist inevitable historical change. ${ }^{62}$ The play was not understood by the critics, who attacked it as anachronistic. Set in 1913 in Jewish Odessa, it staged a bygone Jewish world, so it was perhaps not surprising that it flopped on the Moscow stage at a time when critics were clamoring for descriptions of socialism under construction. This did not deter Babel' from further attempts at writing plays. In 1935, his play Maria (Мария), part of a planned Civil War trilogy, was repressed while in rehearsal at the Vakhtangov and Jewish theaters in Moscow, although it did appear in print. Besides a Gogolian comedy about a town that had gone mad, and a play about the Civil War hero General Grigori Kotovsky, whom he knew, Babel' started on the sequel to Maria, titled The Chekists (Чекисты), which would have undoubtedly been no less controversial. ${ }^{63}$

Babel"s search for a new literary form is intimated in attempts at a novella, The Jewess (Еврейкa), but the struggle for a tighter, sparser prose is also seen in his novel, Velikaia Krinitsa (Великая Криница), set during Stalin's "great leap forward" and the forced collectivization which was to result in the death by starvation or deportation of millions of peasants. In addition, rapid industrialization was 
achieved with shock workers who were encouraged to over-fulfill their norms. Yet writers were expected to give a rosy picture of the factories and villages of the Soviet Union. Judging from the two chapters of Velikaia Krinitsa that survive, and the announcements of forthcoming stories in the Soviet press, Babel' seems to have conceived the book as a cycle of loosely-connected stories along the lines of Red Cavalry. ${ }^{64}$ There is no alienated intellectual torn by identity crises, and the often lurid imagery of Red Cavalry has vanished. The sparse prose drives home the horror of collectivization, rendered the more shocking by the absence of any justification or commentary (as we will see in chapter seven).

Another story about changes in the USSR, and one that Western critics often take as Babel"s subservient lip-service to conformism, is "Oil" ("Нефть"), first published in 1934. The story is told in the form of a letter by a woman in the oil production industry, which notes the impossibly inflated production targets and the trials of specialists in the state planning and production sectors (a reference later removed by the censor). At the same time, the story brims over with enthusiasm for the sheer vastness of the task to be undertaken, the excitement of new births and new outlooks on life, and the vista of Moscow as a huge construction site.

\section{The Price of Silence}

The danger of political incrimination began long before the Purges with a public quarrel over Babel' between Budenny and Gor'ky. Budenny's attack on Red Cavalry had not been forgotten, and Gor'ky felt compelled to come once more to Babel"s defense in 1928, during the escalating battle between ideology and art. ${ }^{65}$ Budenny repeated his attack on Babel"s alleged pornographic calumny, charging that all Babel' had ever seen was a remote backwater in the rear of the First Horse Army. ${ }^{66}$ Gor'ky responded with a tribute to Babel"s ability to make heroes of the Cossacks in Red Cavalry by embellishing them from within in a finer way than Gogol' had done in Taras Bul'ba. The attack on Babel', wrote Gor'ky, who had not yet resettled in Russia, was unjustified and his indisputable artistic talent was useful to the Marxist cause. ${ }^{67}$ The debate is said to have been stopped by none 
other than Stalin himself, but the controversy was resuscitated whenever Babel's name resurfaced in the Soviet press. The hardliners accused Babel' of failing to understand the revolutionary struggle, and expressing his hostility toward it through the figure of Liutov. If Budenny's initial attack had amused Babel' and boosted sales of Red Cavalry, now the question of Babel's loyalty seemed to be answered by his failure to produce ideologically suitable material. The danger in which Babel' stood was appreciated by Gor'ky, who came to the defense of "lynched" writers and Jewish authors in 1928-1929. Gor'ky tried to deflect some of the damaging ideological implications of Babel"s writing, arguing that ideological considerations could not override artistic evaluation.

In 1929, the Zamiatin and Pil'niak affairs highlighted the lack of artistic freedom in Soviet Russia. Now one risked one's reputation by residing or publishing abroad. Babel' had both of these on his record, and he faced the even more serious charge of having made anti-Soviet statements to the Polish press when, in 1930, Warsaw's Wiadomości literackie carried an interview Babel' was supposed to have given, in which he was made to sound sick of the Bolshevik regime and resigned to emigration on the sunny French Riviera. Communist rule, he was "quoted" as saying, had bred only death and disease, and the sun had last shone brightly in 1914. Since then the sky had turned red with the Bolshevik flag and human blood. Babel' had to recuperate in the South of France, but what he most needed from the doctors were injections of faith. "Have you heard of Gedali? He is superior to Lenin! Lenin formed an International of exploited people, but Gedali brought together good people. What a brilliant crazy idea - 'Good people of the world - unite!'”,69

Significantly, the reported conversation with Babel' on the Côte d'Azur was not dated, which would give the impression that Babel' was still abroad. In fact, Babel' had returned from France in 1928, and the article was a crude reworking of Babel"s Red Cavalry story "Gedali," though it was sufficiently convincing for some, despite the parodic and hysterical style uncharacteristic of the real Babel'. ${ }^{70}$ The émigré Polish Communist Bruno Jasieński seized upon the "interview" as evidence of Babel"s questionable loyalty as a Soviet writer. ${ }^{71}$ Babel' quickly sent off a letter to the editors of Literaturnaia 
gazeta pointing out that he had, of course, never given the interview, but, since Jasieński had raised the question of Babel"s right to call himself a Soviet writer, Babel' was called upon to make an immediate public statement. At the hearing before the secretariat of the writers' organization FOSP on 13 July 1930, Babel' defended himself by declaring his unquestionable allegiance. In line with his usual tactic of mystification, he repeated the story of his apprenticeship with Gor'ky and ascribed his silence to characteristically long drawn out creative work on a new book. He went on to state that he had indeed disappeared from literature since the publication of Red Cavalry and the Odessa stories, but this was because he could no longer write in his former manner. He went so far as to say he had repudiated the style of Red Cavalry, quipping, "It is a pity that Budenny did not ask me for some assistance in his attack on Red Cavalry because I do not like Red Cavalry." The present "silence" was in fact the greatest service he could offer to Soviet literature, since he had given up the comforts of life made possible by fame and gone into the country, into the collective farms, to get to know Soviet life from inside. This was something the ideological demagogues demanded, though not quite in the way Babel' had in mind. Sensing the need to disassociate himself from the "fellow travelers" whose day was over and aware that his evasive habits were incriminating in the new political climate, Babel' painted himself as someone who had been much maligned and feigned astonishment that he needed to state his innocence. He undertook to sue the Polish newspaper and was exonerated. ${ }^{73}$ Babel' reported to his family abroad that he was bearing up well to what he called a "nasty business."

In its front-page headline on 3 September 1930, Wiadomości literackie splashed across the entire page the news of the sensational Warsaw court case Babel' had brought against it. The paper summarized Jasieński's article in Literaturnaia gazeta and printed a reply by Aleksander Dan to Babel"s letter in Literaturnaia gazeta, in which he had protested that he had not been on the Riviera and had never heard of Dan. Dan explained that he had met the Russian who introduced himself as Babel' in fall 1926 (when Babel', as we know, was not in France) and later "reconstructed" the conversation after reading the German translation of Red Cavalry. The Polish 
newspaper claimed that it had fallen victim to a ruse, but also maintained that the "interview" reflected the spirit of what Babel' had actually written in Red Cavalry. Moreover, it noted the repressive atmosphere in Soviet literature, of which Maiakovsky's suicide and Jasieński's attack on Babel' were indicative. Babel' had to disassociate himself from what could be construed as a "foreign anti-Soviet campaign." ${ }^{75}$ But at least Babel' could still set the record straight and have his version published; nevertheless the book which he promised to account for his productive silence never materialized.

If his solitary existence in Molodenovo was a form of selfsacrifice intended to bring nearer the day when he would see his family again, it was to prove a sacrifice in vain. Babel' implored his mother and sister not to "jog" his hand as he wrote his way to their reunion.

My whole way of life-hard-working, solitary, single-minded-is subordinated to that end, and if you don't count my professional thoughts, then my thoughts of you engulf me entirely. Mon amie, if one is going to acquire relatives, then one should pick them from among peasants; if one is going to pick a trade-make it that of a carpenter and house painter; if one is going to marry, it should be to a pock-marked cook. But as you and I have fulfilled none of these recipes for happiness, then we must, first, develop bonne mine and second, struggle, break our way out, surmount our troubles, quand même et malgré tout. I dare to give you advice from my sublime distance because every hour, every moment, I share your misfortunes. I share them in spirit and wish for nothing so much as to share them physically. You see now what a classically Jewish "family man" I've turned into.

Still, for all his encouragement to them to follow his example and look on the brighter side of life, to decorate their houses "with gaiety and not with tsores [sorrows]," worrier than they. Babel' characterized himself as an "animal with a long period of gestation,",78 and he realized that the intensive work on new stories had yielded reams of notes and drafts, but little in the way of quantity that was actually publishable.

What Babel' did manage to publish by the end of 1931 were the promising beginnings of the book Story of My Dovecote, and 
one chapter of the collectivization book, Velikaia Krinitsa. The publication of another Odessa story, "Karl-Yankel," proved embarrassing, since the attention of the foreign press was drawn to its account of a mother on trial for having had her baby circumcised, after it was reprinted in an émigré newspaper in Paris shortly after its publication in Moscow. ${ }^{79}$ Babel' tried to play down the importance of the story, typically evading the political implications by claiming it had been printed in a distorted and uncorrected form:

Удивляюсь тому, что в зарубежной прессе пишут о таких пустяках, как “Карл-Янкель”. Рассказ этот неудачен и к тому же чудовищно искажен.... Вообще, то, что печатается, есть ничтожная доля сделанного, а основная работа производится теперь. С похвалами рано, посмотрим, что будет дальше. Единственное, что достигнуто,-это чувство профессионадизма и упрямства и жажда работы, которых раньше не было. (Собрание сочинений, IV, 300)

It is a matter of considerable surprise to me that the foreign press should be interested in such insignificant things as "Karl-Yankel." The story isn't too good to start with and, on top of that, it has been horribly distorted. ... In general, what's being published is a quite insignificant part of my work-I am writing the bulk of it only now. It is too early to shower me with praise-we'll see what there is to come. The only thing I know I have gained is the feeling of having become a professional writer and a will and eagerness for work such as I have never experienced before.

This was a time when Babel' was awaiting a decision on permission to go abroad and to be granted foreign currency, so he could not afford any further uproar like the Warsaw provocation. Yet he could be eminently impractical in his devotion to his art. Only ten days later he wrote his mother:

Yesterday and today I worked a lot and have drafted a story that strikes me as poetic and simple, and is on a quite unexpected topic. I haven't yet given a thought to practical considerations concerning it. I know I ought to have done so. But still, I've derived moral satisfaction from it. ${ }^{81}$ 
By 1932, Babel' was marking a further seven-year "silence" one that matched the first period of "going into the people" in his "Autobiography." In a revised ending of his "Autobiography," which he prepared that year, he wrote that his silence could be explained by his wandering about the country and getting up strength for his new work. ${ }^{82}$ Yet, once more, Babel' was out of tune with the ideological orthodoxy of his times. The Party was taking control of literature just as it had taken control of every other field of life. Writers were now to be required to conform to the dictates of Socialist Realism, which required unswerving allegiance to Party control (partiinost'), demonstrative recognition of the class conflict as regulating human affairs (klassovost'), and identification with the people (narodnost'). The formation of the Soviet Writers' Union set up a powerful body that could both discipline wayward members and distribute "privileges" to those in favor with the authorities. The First Congress of Soviet Writers in 1934 was to be a historic parting with any remaining pluralism in art.

In his introduction to the 1955 English translation of Babel"s Collected Stories, Lionel Trilling called Babel"s speech at the 1934 First Soviet Writers' Congress a "strange performance."

... beneath the orthodoxy of this speech there lies some hidden intention. One feels this in the sad vestiges of the humanistic mode that wryly manifest themselves. It is as if the humor, which is often of a whimsical kind, as if the irony and the studied self-depreciation [sic!], were forlorn affirmations of freedom and selfhood; it is as if Babel' were addressing his fellow-writers in a dead language. . .

Babel' went through the motions of praising Stalin. However, he then declared himself a "master of silence." ${ }^{84}$ The established convention was to laud Stalin as the leader of a nation united in the struggle for communism, and Babel' did note the unified struggle of the people, but said it was a struggle against trite vulgarity (poshlost'), which he termed "counter-revolutionary." Stalin had called writers "engineers of the human soul," but Babel' gently reminded his listeners that their profession necessitated "a difference in their feelings, tastes and methods of work." It was an exciting time-the first scaffolding was coming down from the 
building of socialism - but writers would be failing in their task if they went around shouting their happiness through megaphones, which was the usual manner of writers in the service of Stalinist propaganda. If things went on like this, he joked, declarations of love would be made over loudspeakers like announcements at a sports stadium.

Babel' won applause and laughter in his light-hearted protest against the personality cult, but he was no doubt speaking sincerely when he held the writers themselves responsible for describing adequately the historic transformation of the Soviet Union. Above all, they were responsible first of all to the reader (and by inference not to the Party). Soviet readers demanded literature, and one could not put a stone in their outstretched hands, only the "bread of art." But mass-production literature would not do, it had to be quality literature, a literature of ideas. The writer had to bowl the reader over with the unexpectedness of art. Regarding respect for the reader, Babel' declared, arousing the audience's laughter: "I suffer from a hypertrophy of that feeling. I have such unlimited respect for the reader that I am struck dumb and I fall silent" (Собрание сочинений, III, 38).

To say that the writer had to know collective farms and factories inside out and at close hand was a way for Babel' to justify his silence as being essential, since all this required much time and thought. Perhaps he was unduly optimistic or ironic in assuming that, in the Soviet Union, differences among writers could be maintained in the face of mass conformism. To this end, Gor'ky had endorsed the purpose of the Writers' Union to organize writers for collective work in construction of the new socialist culture. ${ }^{85}$ However, it was precisely collective work to which Ehrenburg was opposed, and, in his speech, Olesha insisted on being himself, pleading to be allowed the freedom to devote himself to the dreams of the new Soviet youth, since he could not describe factories. ${ }^{86}$

Babel' was probably correct in claiming that in the capitalist West no publisher cared whether he had something different or important to say, or "whether," as Ehrenburg put it, "I was a rabbit or a she-elephant" (Собрание сочинений, III, 39). However, Babel' managed to introduce irony into this situation by following 
Gor'ky in referring to the slogan coined by a previous speaker, Leonid Sobolev, "The Party and the government have given the writer everything and have taken from him only one thingthe right to write badly." Babel' concluded amid laughter, with significant double meaning: "Comrades, let us not hide the fact. This was a very important right and it is no little thing being taken away from us. This was a privilege of which we made much use" (Собрание сочинений, III, 40). The right to write badly was a privilege that writers had abused, and in giving it up they would have to be responsible for their art and freedom.

The importance to the Party of the First Congress of Soviet Writers may be measured by the fury of the embarrassed Soviet literary establishment at Max Eastman's book, which had appeared a few months before, Artists in Uniform: A Study of Literature and Bureaucratism. It presented a very different picture from the one that the Party wished to give. Describing in full the Zamiatin and Pil'niak affairs, Eastman exposed systematic repression of artistic freedom. The chapter entitled "The Silence of Isaac Babyel" lauds Babel' for not prostituting his pen to the apparatchiki and admires his silence, a treasonable act for which he risked severe punishment. Eastman guessed that Babel' survived not because of his evasiveness, but because of powerful connections and a peculiar privilege Stalin had accorded Gor'ky, Babel"s chief protector. The audience who laughed at Babel"s reference to his silence would have undoubtedly heard of Eastman's controversial book. In vain Ehrenburg defended the right of Babel', Olesha, and Pasternak to be different. For Babel', as for Mikhail Bulgakov and Nikolai Erdman, the only option was silence.

\section{The Rest Is Silence}

In 1936, the critic Isai Lezhnev marked the tenth anniversary of Babel"s "silence." ${ }^{88}$ It was made clear that silence could itself be regarded as treasonable, and writers were called upon to demonstrate their loyalty to Stalin. ${ }^{89}$ Yet Babel', like other "writers of silence," had not laid down his pen. Babel"s silence was in fact a productive one, but tragically whenever he seemed near to perfecting his work, the increasingly repressive times made publication impossible. 
In 1937, Babel' started making "a neat copy of my many years of meditation - as usual, I find that instead of weighty volumes, I have less than a sparrow's beak to show and that's sure to cause a great outcry." ${ }^{90}$

The truth of the matter is that his book on collectivization, Velikaia Krinitsa, would have been even less acceptable in the 1930s than were the frank descriptions of violence and cruelty in Red Cavalry, which were still drawing fire from Marxist critics. They would hardly be satisfied by a return to old themes such as further Odessa and Childhood stories. What interested Babel' was the extreme, the grotesque, the abnormal; what the Party required were conformism and mediocrity. A lost story, recalled by Semyon Gekht, and which Babel' read to Ehrenburg in 1938, "By the Church of the Holy Trinity" ("У троицы") tells of the loss of many illusions, "a wise and bitter story." ${ }^{\prime 1}$ Neither Kolia Topuz, Babel"s lost novella about a reformed Odessa gangster in Donbass mines and factories, ${ }^{92}$ nor his tales of Kabardino-Balkariia, based on his experiences in Nal'chik as a guest of Betal Kalmykov, were publishable. Betal Kalmykov, the legendary leader of the Kabardino-Balkariia region, fell into disgrace and was arrested, possibly because Stalin could not abide any rival cult figures, least of all one who so successfully modernized his region and transformed it into what Babel' termed a gem of the Soviet Union, a paradise, by Soviet standards, of rich harvests and abundance.

Another writing assignment took Babel' to the Don valley, a mining and industrial region at the heart of the Stakhanovite movement. There he befriended a local Communist, Benjamin Furer, a young protégé of Kaganovich. Furer committed suicide at the end of 1936, leaving a lengthy letter explaining he could no longer reconcile his loyalty to the Party and the arrests of innocent people..$^{94}$ Babel"s powerful friends from Civil War days, Yakir and Tukhachevsky, also fell, and their trials considerably upset Babel'. A deeper and more personal blow came in 1936 with the loss of Gor'ky, his chief protector and mentor. "That man was my conscience and my judge," wrote Babel' after Gor'ky's death, "an example to me. I was linked to him by twenty years of unspoiled friendship and affection. The way for me to live up to his memory now is to live and work, and to 
do both those things well." ${ }^{95}$ The deaths of his fellow Odessites, the poet Eduard Bagritsky in 1934 and the humorist Il'ia Il'f in 1937, left Babel' lonely and surrounded by mechanical loudspeakers blaring out praise for the Leader. Several writers who chose not to blare out praise were arrested-among them Osip Mandelstam, who was banished to Voronezh, and the playwright Nikolai Erdman, whose second arrest Babel' came close to witnessing when he was holidaying in the Caucasus with Pirozhkova. ${ }^{96}$

Viktor Shklovsky, associated with the condemned formalists in literary criticism and with the heresy of a "South-Western" or Odessa school of Russian literature (which included Babel', Bagritsky, Olesha, Il'f and Petrov), recanted. The internationally renowned film director Sergei Eisenstein was also in hot water, and was forced to confess his "ideological errors" in a self-critical speech on 25 April 1937. Eisenstein had worked with Babel' on a revised version of Bezhin Meadow (Бежин луг) in 1936, an adaptation of a Turgenev story that told of a boy, Stepok, who betrays his father for plotting to burn down the collective farm, as in the legend of the Soviet Komsomol member Pavel Morozov. The film was banned, and responsibility fell not just on Eisenstein's head, but also on his collaborators.

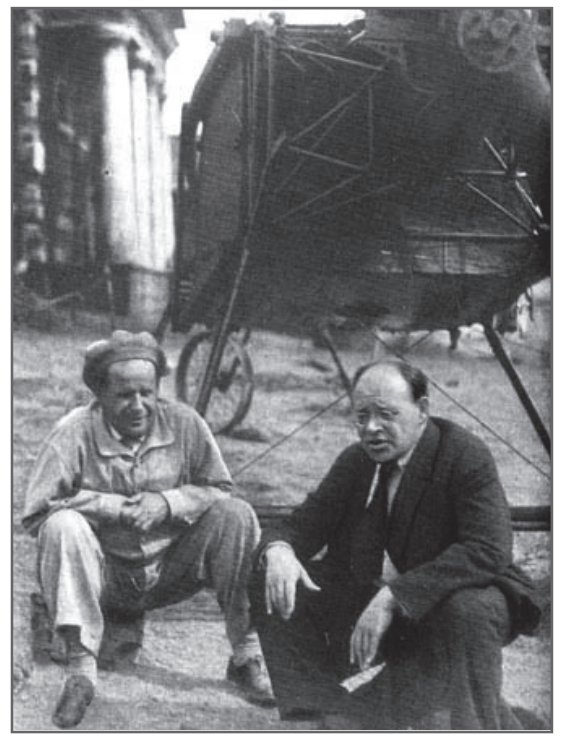

Babel' and Eisenstein, 1936 
The assassination of Leningrad Party boss Sergei Kirov in 1934, after Kirov's advocacy of reconciliation with critics of the leadership, had given Stalin an excuse for stepping up the persecution and the show trials of political enemies, including Genrikh Yagoda, Lev Kamenev, and Grigory Zinoviev. The denunciations and purges intensified, climaxing in the Great Terror of 1937. The public campaign from 1936 onwards against "Trotskyism" and "formalism" in art, fanned by Karl Radek's attack on Joyce and modernism and by the campaign against Shostakovich, provided another opportunity for settling old scores and for demanding declarations of total obedience. Babel' was not prepared to sell his soul and he behaved with maximal reticence when required to address public meetings to denounce "Trotskyists" and "formalists." speak about maintaining cultural values and human decency, knowing these were being destroyed, and he would further explain away his silence by attributing it to dissatisfaction with himself. His fastidiousness was, he said, a feature of his "difficult character" that distinguished him from others who rushed out verbose novels about life in a factory. ${ }^{99}$ Rarely is Babel"s signature found on the collective letters denouncing some "enemy of the people," which writers were pressured into signing for publication in the official newspapers.

It was becoming increasingly difficult to buy time from editors, and Babel' was threatened by bailiffs because of his accumulated debts. ${ }^{101}$ And so it continued-Babel' took advances from editors to buy time to work on his stories, but found it impossible to do so because of having to complete hack work, while pressured constantly to produce "suitable" material. Babel"s letters from Paris and Sorrento in 1932-1933 show his apprehensions that the censor might not pass his new work. ${ }^{102}$

The 1935 Paris Congress of International Writers protesting German fascism proved to be a last brief occasion for Babel' to visit his family. Babel' and Pasternak were sent only after the French left complained about their absence from the Soviet delegation. The congress was an opportunity for Soviet propaganda, but the infringement of personal and creative liberty in the USSR, as well as arguments within the Soviet delegation and the factionalism of 
the French left, largely discredited this effort. Not surprisingly (as Ehrenburg recorded in his memoirs), the impromptu addresses of Pasternak and Babel' were met with wild applause. ${ }^{103}$ Back home, the pressure to conform intensified: "I've been told," he wrote to his relatives abroad, "that I'll be able to see my family any time I have some 'output' to show. . ." ${ }^{104}$ In his eulogy for Eduard Bagritsky in 1935, Babel' regretted the poet could not realize their shared dream of retiring to sunny Odessa. ${ }^{105}$ Little did he suspect how small was his chance of living out his old age in the seaside villa he had planned.

\section{The End and After}

To what extent did the Stalinist terror shake Babel's natural optimism and idealistic faith in a better future? How did he rate his chances of survival and how much was he risking in maintaining his "silence"? What finally brought Babel' down? How much did Babel' manage to write that has been lost to us? Firstly, we must bear in mind the complete divorce made by Babel' between his writing and his private life. Few were privileged to see what lay at that moment under his pen or in his chest of manuscripts. A cartoon accompanying the 1932 publication of "Guy de Maupassant" caricatured Babel rummaging in the famous chest of manuscripts, labeled "Luggage 1919," with the caption from Pushkin's Miserly Knight: "Every time I wish to open my trunk, I fall into sweat and trembling...God knows, how many bitter exclamations, awakened passions, heavy thoughts, daily cares, sleepless nights all this has cost?" ("Я каждый раз, когда хочу сундук свой отпереть, впадаю в жар и трепет... Бог знает, сколько горьких воздержаний, обузданных страстей, тяжелых дум, дневных забот, ночей бессонных все это стоило?") ${ }^{106}$ Antonina Pirozhkova was strictly forbidden to look at the manuscripts on which Babel' was working, and her lack of a literary background was an advantage for Babel"s secretive habits, in contrast to the relative openness he had displayed in his correspondence with his Russian mistress Tamara Kashirina.

Secondly, Babel' was far from being a political creature. He was not a member of the Party. When living a hermit's existence 
at Molodenovo, he doggedly resisted attempts at conscripting him for "consultation sessions" with shock workers. Later, when offered a writer's dacha in Peredelkino, Babel' was mainly concerned that the houses be sufficiently distant from one another to assure him privacy so he could get on with his writing. ${ }^{107}$ These were times, Babel' told Il'ia Ehrenburg, when a man could only talk with his wife in bed, and then only under a blanket. ${ }^{108}$ With horror he talked of the incarceration of children of living parents in orphanages, and the recycling in a paper factory of books by banned authors.

Babel"s conversations in Moscow with the Hungarian Communist Ervin Sinkó, and in Paris with the émigré Boris Suvarin, who was writing a biography of Stalin, show how up-to-date he was on daily arrests and that he was aware of what was going on inside the Party. ${ }^{110}$ Nadezhda Mandelstam has testified that Babel"s Moscow apartment remained one of the last refuges to which the families of those who disappeared could turn for support and counsel. Babel' would go off somewhere, relates Pirozhkova, and return dejected, attempting to reassure the victim's relatives.

In 1937, he wrote to the Writers' Union complaining that his books were no longer available at bookstores or libraries; the last edition of his collected stories appeared in a heavily censored volume in 1936. In a New Year message for 1939, Babel' made a veiled protest about the withdrawal of Tolstoy's works from circulation; ${ }^{112}$ not only living writers were being repressed. Babel' held a number of editorial posts, but the ring was tightening. We now know that Babel' had been under surveillance since 1934 . About a year before Babel's arrest, the NKVD placed a plant in the Babel' household, in the person of Yakov Efimovich El'sberg, who worked for the Academia publishing house. Pirozhkova was used to finding all kinds of guests visiting or staying, so she was not suspicious of El'sberg's obsequiousness in arranging for repairmen or decorators who appeared with lightning speed. Babel' seems to have been simply amused when El'sberg accompanied Pirozhkova to the opera one night and brought her home in a smart black car. ${ }^{13}$

Ezhov, NKVD chief from 1936, suspected Babel' of having an affair with his wife, Evgeniia Solomonovna (née Khaiutin), who was an old friend of Babel' from Odessa (she apparently committed 
suicide in winter 1938 after the arrest of a close friend). Babel' was known to frequent Ezhov's home and Osip Mandelstam was moved to ask him for his motives. Did he actually want to touch death? "No," Babel' replied: "I just like to have a sniff to see what it smells like." ${ }^{114}$ Babel' wanted to understand how Yagoda and Ezhov could instigate such inhuman terror, but to satisfy his writer's curiosity he had to get dangerously close. Once he asked Yagoda what to do if arrested, and Yagoda replied he should deny everything; later he thought Yagoda was more humane than Ezhov. ${ }^{115}$

In early 1939, Babel' decided to live on his own at Peredelkino in order to work on his new book. Upon its successful completion, he intended to have Pirozhkova and their daughter Lydia join him from Moscow. There remained a couple of film scripts to finish-the completion of Gor'ky's Trilogy, which Babel' had promised Gor'ky's widow to undertake in order to ensure that the filmmakers did not take liberties with the original, ${ }^{116}$ and the script of a children's film, No. 4, Old Square (Сmapas nлощңadb, 4), about an airship, USSR 1, which Babel' wrote within the space of only twenty days. ${ }^{117}$ His last letter on 10 May 1939 announced he was now installed in his Peredelkino home and would soon "devote himself to the final polishing" of his "true work," which he intended to hand in by the fall.

At five in the morning on 15 May 1939, Pirozhkova was woken up by four NKVD officers asking for Babel'. Tat'iana Stakh, an old friend of Babel's, was staying over in the Moscow apartment and witnessed the search, which included confiscation of Babel"s manuscripts, an old saber (a weapon!), and the title pages of books, as well as inscribed dedications in them (including one from Trotsky). ${ }^{119}$ Two of the NKVD men accompanied Pirozhkova to the dacha in Peredelkino where they forced her to knock on Babel"s door and then, once they had searched him for weapons like some dangerous criminal, they arrested him.

It is estimated that of the six hundred delegates to the First Congress of Soviet Writers, at least half failed to survive the Stalin years. Some were arrested, some died prematurely or committed suicide, some simply disappeared. Stalin's megalomania tolerated no rivals, and he was suspicious of potential subversion everywhere. 
The most talented writers and artists perished or were silenced, with a few exceptions for reasons we may never fully understand. It would be only a matter of time before the discovery of a "conspiracy" of writers plotting to undermine communist rule and to carry out counter-revolutionary acts of terrorism. Babel"s arrest on 15 May 1939 was apparently carried out "preemptively"; that is to say, the NKVD had no firm "evidence" of the conspiracy, but it was hoped that Babel' could quickly be broken and made to incriminate other members of the literary fraternity. The warrant for Babel's arrest was in fact signed by Beriia thirty-five days after he was picked up. Also arrested were the journalist Mikhail Kol'tsov, a loyal supporter of Stalin and a Spanish Civil War veteran, and the theater director Vsevolod Meierhold. Fadeev was called in by Stalin and shown Meierhold's "confessions"; apparently the dictator wanted the tacit support of the Soviet Writers' Union and, consequently, their complicity (Fadeev was ordered to phone Babel' and ask him if had produced anything new or if he wanted to go away, which may have been a warning). Other potential candidates for inclusion in the "conspiracy" were Yurii Olesha, another writer of silence, and Boris Pasternak, the leading Russian poet, neither of whom were arrested.

In order to fabricate a strong case against the "conspirators," the investigators drew evidence from any contact with foreigners or persons abroad to prove espionage for a foreign power. In addition, involvement during the twenties with literary journals such as Voronsky's Krasnaia nov' or its successors Pereval and the Krug publishing house brought accusations of ideological subversion. Moreover, contact with anyone later disgraced testified to active membership in a "Trotskyist" terror organization. Extracts were read to the accused from the confessions of other prisoners indicting them in anti-Soviet activity, although, unknown to the accused, they may already have been executed (as was Pil'niak in Babel"s case). The signed "confessions" were often extracted with the persuasive help of beatings that were repeated on the most painful areas of internal bleeding. ${ }^{121}$

From the papers in the NKVD files it seems that the initial grounds for suspicion offered to substantiate Babel"s "crime" were 
association with arrested "Trotskyites" based on their testimony (or testimony that was put into their mouths). S. B. Uritsky, former editor of Krest'ianskaia gazeta, testified to meeting Babel' at Ezhov's home and hearing him express anxiety about his silence being considered an anti-Soviet act, as well as about the arrest of close friends. "A writer," Babel' was reported to have said, "must write with sincerity, but what he writes with sincerity is not publishable because it does not fit the Party line." This allegedly demonstrated Babel"s sense of his own guilt, his Trotskyite views, and his links with Ezhov, who had been arrested as an enemy of the people and who denounced both Babel' and Mikhail Kol'tsov (already arrested in December 1938) as spies for the British in collusion with his wife. ${ }^{122}$ Furthermore, the "intelligence source" (protectively unnamed in the dossier) reported remarks made by Babel' in 1934 about the Great Trials. Babel' lamented the destruction of the best talents and the lack of any real leadership (to say that innocent people were being arrested was obviously a Trotskyite plot to incite anti-Soviet feeling). By 1939, Babel' was reportedly expecting his own arrest. None of this constituted evidence that would stand up in any kind of court, so beginning on May 29, Babel' was subjected to three days of ruthless interrogation. At first, Babel' did not buckle under, but in the end a confession was extracted that incriminated him in a Trotskyite terror organization. Babel' admitted that in 1924 he had been invited by Voronsky, then editor of Krasnaia nov', to Bagritsky's reading of his new poem The Lay of Opanas, in the presence of Trotsky and Radek. Babel' denied he ever saw Trotsky again, but in the perverted logic of the interrogators the link was established both with Trotsky and an "anti-Soviet" writers' group around the disgraced Voronsky, which was at the end of the twenties a last stronghold of independent writers and "fellow travelers" who withstood the wholesale destruction of literary values. The figure of Trotsky could be shown to explain the "anti-Soviet" views expressed in Red Cavalry, where Babel' had, in the words of the dossier, deliberately ignored the role of the Party in the war and slandered one of the units of the Red Army. Subsequently, during de-Stalinization, it turned out that two of Babel"s interrogators, Schwarzman and Rodos, could not see-even 
when on trial themselves - why they should have actually read Red Cavalry.

Another count in the charges against Babel', under section 58 of the criminal code of the RSFSR, was that of spying for a foreign power. Babel' was made to confess that his contact was the French writer André Malraux, to whom he had been introduced during his stay in Paris in 1933. Babel' had also met with Malraux in Russia when Malraux visited Gor'ky in 1934 and again in 1936 (accompanied by Mikhail Kol'tsov, one of the arrested writers), ${ }^{123}$ as well as during the 1935 Anti-Fascist Congress in Paris. Malraux rated Babel' highly, and Babel' regarded him as a useful protector; in fact, he hoped that word of his arrest would get to Malraux. The information Babel' passed on to Malraux concerned, by his own admission, a critical account of the true mood of Soviet society during the show trials, the state of literature, collectivization, and items from the Soviet press on Soviet aviation. So Babel' "confessed" to being a French and Austrian spy-his former Moscow flat-mate, the Austrian Bruno Steiner, a representative of an engineering company until he left Russia in 1936, came in handy here-as did his contacts with Trotskyites and other Russians living in Paris, among them Il'ia Ehrenburg, with whom Babel' discussed the mass arrests on Ehrenburg's return to Moscow from Spain.

As if these accusations were not sufficiently absurd, the interrogators persuaded Babel' to confess that he had been involved with Ezhov's wife in a terrorist plot against Stalin and Voroshilov (a common charge against victims of the purges). Babel"s role was supposedly to undermine morale and influence public opinion, which was an admission of sorts of the danger Stalin, like the Tsars, sensed in writers-attempting to overthrow the existing system was also one of the charges Babel' claimed he had faced under the ancien régime (Собрание сочинений, I, 41). In his interrogation on 11 May 1939, Ezhov, who suspected his wife had previously had an affair with Babel', said he had thought Babel' might be working together with his wife for British intelligence. Questioned in July 1937, N. N. Zarudin, sentenced (like Ezhov) to be shot, had named Babel' along with Kataev, Pil'niak, and Vasily Grossman, as members of Voronsky's "terrorist conspiracy" against Ezhov. 
However, Voronsky, arrested in winter 1937 and later executed, did not mention Babel' at all. It could be that Ezhov was behind the idea of framing the writers, and, after he fell, gatherings of writers at his apartment could be used to implicate Ezhov himself in an antiSoviet conspiracy.

Babel' could not hope that the absurd pack of lies and insinuations would be subjected honest judgment and must have realized that his fate was sealed. In a letter to Beriia, dated 11 September 1939, Babel', full of the required contrition at his "criminal" past, asked for the confiscated manuscripts, the fruits of the past eight years' work, so that he could put them in order-these included the drafts of the collectivization book, a number of stories, a scenario and an incomplete play, as well as material for a book on Gor'ky. He presumably wished to leave his new book, so long awaited, to posterity. This was denied him.

It was established routine that, since a crime was assumed, the accused was expected to name his accomplices. In Robert Conquest's estimation, the arrest of such "accomplices," and of many who had merely come into contact with the accused, widened the scope of the mass arrests to as much as five percent of the total population. ${ }^{125}$ The interrogators were therefore eager to extract from Babel' a list of people with whom he had held "anti-Soviet" conversations: they noted down Yurii Olesha and Valentin Kataev, both of them fellow Odessites; the Yiddish actor and director of the Moscow Jewish Theater, Solomon Mikhoels, murdered in 1948; the film directors Aleksandrov and Eisenstein and other less well-known personalities.

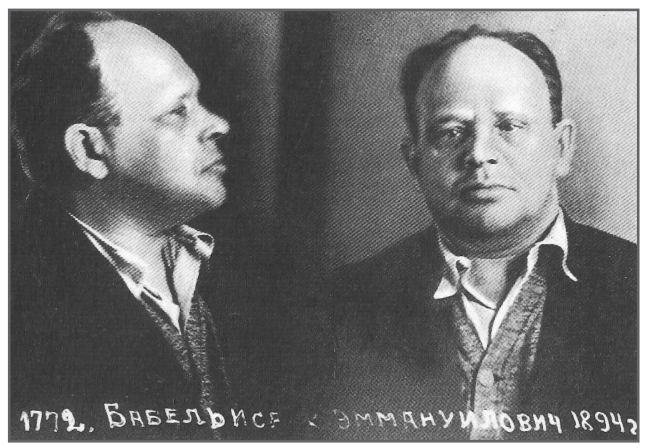

NKVD photo of Babel', 1939 
The recording of these names could later be used in evidence against them, and Babel' must have realized this when, on 19 October 1939, he retracted his confession: "I beg the investigation to note that in giving evidence I committed a crime, even while in prison: I slandered a number of persons. .." This was typical of Babel"s self-effacement up to the very end and consistent with his intellectual honesty and integrity. At the very least he did not want his friends to be harmed through their association with him; Ehrenburg was particularly implicated in the "French connection." On a scrap of paper dated 5 November 1939, Babel' scribbled an appeal to the State Prosecutor's office to be allowed a hearing before his case went to trial. Having received no reply, he wrote again on 21 November, once more asserting that he had in his confessions made false statements implicating persons who were innocent of any crime and only worked for the good of the Soviet Union. "The thought that my words not only do not help the investigation but could do direct harm to my country gives me no rest." ${ }^{126}$ A third letter on 2 January 1940 likewise went unanswered, as did an appeal to the Military Collegium of the Supreme Court, sent 25 January 1940, asking to see his case and call witnesses. ${ }^{127}$ At his trial, held the next day on 26 January 1940, Babel' protested that he was innocent of any act against the Soviet Union and that he retracted the confessions which had been forced out of him. He was given a last word, in which he requested to be allowed to finish his book, a draft version of which he had completed by the end of $1938 .{ }^{12}$ The military collegium sitting in judgment read out the death sentence. Execution was promptly carried out on 27 January 1940. Meierhold and Kol'tsov were executed shortly afterwards, on 2 February 1940.

The military tribunals would try cases and pronounce sentences on a "conveyor-belt" system: twenty minutes per victim. The trials were held secretly, behind closed doors, and no witnesses could be brought by the prisoner, who was also not allowed a defense attorney. The transcripts of the interrogation and trial of the three arrested writers-Babel', Meierhold and Kol'tsov-suggest clearly why a show-trial was never staged. None of them, even after being broken, offered the kind of material required for a public show- 
trial. Even when faced with the prospect of death they did not seem willing to turn state witness against other writers. Moreover, the great anti-Trotskyite show trials were over, and Ezhov himself had fallen. Now the removal of "enemies of the people" - that is to say, the intellectual and military elite, as well as remnants of the former opposition and old guard-was proceeding quietly and efficiently. The relatives of those executed were told that their loved ones had been sentenced to ten years without right of correspondence.

It is possible that Stalin shelved plans for a writers' trial after the Ribbentrop-Molotov pact, signed in August 1939, which brought the Soviet Union into a non-aggression agreement with the fascist regime, whose book-burning and destruction of its intellectuals had been so often attacked in the Soviet press, and with the expansion of Soviet rule to the Baltic states and eastern Poland in 1940, the secret police were required to remove intellectuals and political leaders in the newly annexed territories quietly and discreetly, which would hardly be possible if all eyes were turned on public trials of leading Soviet writers. It would certainly not make much sense for Babel' to play the role of an Austrian as well as French spy once the Reich was no longer an enemy of the USSR. We can only guess why, in August 1939, there was a changeover in Babel"s investigating team and an unexpected official request was made to extend the proceedings in order to procure more evidence, or why, after the interrogations were ended, the detention period was extended in anticipation of further orders from above. ${ }^{129}$ It has been suggested that the entire machinery of arrests and secret trial was now geared to the internal legitimation of the Soviet regime and its changing foreign policy. ${ }^{130}$ In any case, the list of persons to be executed was personally approved by Stalin himself. ${ }^{131}$

For a while, until Babel' was transferred to the Butyrsky prison for trial and execution, Pirozhkova's parcels were accepted at the Lubianka. One day she was visited by NKVD officers, who asked her to give them clothes for Babel', which she mistakenly thought a good sign. For some years afterwards former inmates or their relatives kept Pirozhkova informed of rumors that Babel' was still alive in some distant labor camp, that he lived in a hut on his 
own with plenty of writing paper, or that he had died of a heart attack in a camp. ${ }^{132}$ The authorities clearly did not wish to risk the slightest disturbance, least of all any public opposition. Even after Babel"s rehabilitation following the review of his case in 1954 by the Military Collegium of the Supreme Court, the world was told he had died (in unspecified circumstances) on 17 March 1941. This might have been in line with the general policy to postdate deaths to make them seem war casualties or to imply death from natural causes during confinement. The full truth was something that could provoke unrest, especially since the concentration camp system was still maintained and even repopulated. De-Stalinization had to be limited to excesses and abuses in the system, and could not be allowed to lead to its delegitimization.

Strangest of all, an arrested man's innocence did not suffice to clear his name. Although the investigating judicial commission could find no basis for legal action against Babel', Pirozhkova had to procure three character witnesses for the rehabilitation process. She chose Gor'ky's widow Ekaterina Pavlovna Peshkova, Il'ia Ehrenburg, and Valentin Kataev to testify to Babel's loyalty to the Soviet Union. Peshkova confirmed Gor'ky's evaluation of Babel"s talent and reliability as a Soviet citizen, while Ehrenburg asserted that Babel' was a confirmed Communist and anti-Trotskyist, though he had to explain away the appearance of Malraux in the indictment, since Malraux was now considered a Gaullist. Kataev, curiously, felt the need to voice reservations about Babel"s work, particularly Red Cavalry. Perhaps Ehrenburg and Kataev still felt jittery prior to the XX Party Congress, and may have realized their own names appeared in the NKVD files.

The times were evidently not ripe for writers to be judged by more enlightened standards, as the Siniavsky and Daniel' trial and the expulsion of Solzhenitsyn from the Writers' Union were to show. Ehrenburg managed to secure the republication of Babel's Selected Works (Izbrannoe), in 1957. Two somewhat enlarged editions followed in 1966, and some new material did appear in distant Central Asian journals through the seventies. A number of critics denied that Babel' had a place in the newly revised history of Soviet literature, since he was identified with the vacillating Liutov, who 
was hostile to the October Revolution when compared with other fictional Civil War heroes. Khrushchev turned against avant-garde art and showed there was a limit to the freedom and liberalization heralded by the Thaw: spring had not yet come. Andrei Siniavsky's arrest meant that his name did not appear in publication of expurgated archival material in 1965; L. Poliak, assigned the task of replacing Ehrenburg's preface to Babel's Selected Works (Izbrannoe) in 1966 commented with hidden irony how difficult it was to write about Babel'. ${ }^{133}$

If Babel' had been accorded a "second life" under Khrushchev, he reverted to a twilight zone during the "stagnation" under Brezhnev and the clamp-down on Jewish activism. Gorbachev's perestroika gave Babel' what Galina Belaia calls his "third life,"134 but even under glasnost' there were some who felt Babel' did not fit within the Russian national tradition, or that it would be unwise to republish his works. ${ }^{135}$ Babel"s full rehabilitation lagged behind that of Pasternak, Mandelstam, Bulgakov, Zamiatin, Tsvetaeva and other writers less favorable to the Soviet regime. At the end of the Soviet period, Pirozhkova managed to bring out a two-volume edition of Babel's stories, plays, film scenarios, memoirs, speeches and correspondence, as well as the full text of the 1920 Diary. ${ }^{136}$ What it did not include were a few minor pieces, but also fragments or incomplete works, such as the novella The Jewess, nor did the notes indicate where the text remained censored. The difficulties of reestablishing a definitive text are understandable, considering the fact that it is nearly impossible to distinguish between the very many stylistic changes which Babel' made in successive editions and the deletions made by editors. The choice of the 1936 edition as the last lifetime version prolonged the censorship; worse, it perpetuated the distortion of the corpus of Babel's work by publishing the stories, apart from Red Cavalry, in order of publication, which, due to Babel"s long "gestation," bears little relation to order of composition or their thematic and chronological sequence. It ignores Babel"s plans, whether thwarted or abandoned, to publish his work in separate books or cycles of linked narratives. In effect, despite restoration of some expurgated passages, most of the recent Russian editions have failed to fully restore what had 
been destroyed by the Soviet system. They have made available in Russia much that had been unpublishable until the end of the Soviet period, when at last it became possible to print material that was critical of the Bolshevik Revolution, such as Babel"s articles for Novaia zhizn' or his 1920 Diary. After the break up of the USSR, two further two-volume editions, in 1996 and 2002, again selected the 1936 Stalinist text, although they also (rather inconsistently) used the texts of first publication of several stories. Some stories first saw light much earlier than was previously thought, so that a false chronological order of publication effectively distorts the history of Babel"s literary career. ${ }^{137}$ In 2006, a four volume edition of Babel"s works and correspondence appeared, compiled by I. Sukhikh, idiosyncratically arranged thematically, and this remains the most complete collection to date. ${ }^{138}$

Alongside the official transcripts of Babel's interrogation there exists his own personal disposition, a handwritten self-criticism. Putting the two together we get a picture, albeit falsified by lies and half-truths, of a man who saw all around him the systematic destruction of culture, but who blamed himself for his failure to complete his life's work. He knew he had been arrested because of his "silence" and his foreign contacts. Looking back, his attempts to truthfully describe collectivization or a typical Soviet family, the Korobkins, among other projects I have already mentioned, were doomed to failure because he touched on the human interest of what was happening in Soviet Russia and could not bring himself to turn his writing into a political statement. Only too late did he realize that his fictional autobiography, that is Story of My Dovecote, had become his own indictment (that is the word used in the transcript of the interrogations), because it was the story of a man who had grown up before the Bolshevik coup in Jewish Odessa, and had tried in vain to reconcile his humanitarian beliefs with the cruelty of the Revolution. He realized how out of place was the Liutov type in the new society where there could be no doubts or individualism. Stalin could barely tolerate the living legends and enfants terribles of the October Revolution, several of whom (Schmidt, Okhotnikov, Primakov and others) Babel' knew personally and named in his interrogation. They had been what one might call Babel"s "heroes of 
our times," and their elimination was to not only help seal Babel"s death warrant, but also to considerably weaken Soviet military readiness when Hitler invaded Russia.

In 1964, Pirozhkova appealed for the return of the confiscated manuscripts. She was officially informed that the manuscripts were not preserved. This accords all too well with Solzhenitsyn's calling the airspace above the Lubianka chimney-stack the most wretched on earth, as it received the smoke of so many burning manuscripts; however, no official order for burning Babel"s papers has been located. Manuscripts do not burn, we are told in Mikhail Bulgakov's The Master and Margarita, and this sustaining hope has maintained our faith that literature can survive totalitarian regimes even if writers cannot. However, Babel"s manuscripts, notebooks, and personal papers, confiscated when he was arrested on 15 May 1939, have not been seen since. Possibly, they were destroyed at the time of the German advance on Moscow in 1941. A new collection of his work was in preparation, New Stories (Hoвble pacckazbl), which was to include stories about "heroes of our times."139 But, as Babel' was heard to say as he was being led away: "They didn't let me finish" ("Не дали закончить"). ${ }^{140}$ What was the "master of silence" working on when he was arrested? What priceless masterpieces have been lost to us? The ashes of Isaak Emmanuilovich Babel' in the mass grave of Stalin's victims in a Moscow monastery are silent. 


\section{REFERENCE AND INTERFERENCE}

\section{Inter-Reference/ Interference}

Interference has been described by Michel Serres as "interreference" because the epistemology of science resembles an encyclopedic web, which resonates with local as well as global references: "Il faut lire interférence, comme inter-référence." In Babel"s Red Cavalry story "Gedali," to introduce interference of a Jewish language (stylized Yiddish) and reference to Jewish texts (Maimonides, Rashi) is to refer to a condemned culture. Murray Baumgarten speaks of "inter-reference" in "Gedali" as a cultural cross-reference that negates the discourse of the Bolshevik Revolution and points to moral irony. ${ }^{2}$ Linguistic interference can be defined as what happens in the speech of bilinguals when the rules of equivalence between languages in contact break down: it is a deviation from the norms of the standard language in the speech of bilinguals. ${ }^{3}$ In the literary text, linguistic interference encodes a referentiality that can be deciphered by readers who are both bilingual or multilingual and versed in reading coded subtexts, as Jews were after centuries of cultural repression in various lands, mastering the languages of often hostile societies, while conversing among themselves in Jewish languages such as Yiddish, a fusion of Middle High German, Slavic, and Hebrew.

As Renate Lachmann notes in her study of intertextuality in Russian modernism, "Intertextuality demonstrates the process by which a culture continually rewrites and retranscribes itself," that is, a book culture renews its semiotic system and redefines itself through signs generated in texts that ensure the survival 
of cultural memory. ${ }^{4}$ In visual arts, and particularly in literary modernism, intertextuality offers a reinterpretation of cultural texts that make up cultural memory and identity. In this case, the repressed cultural identity can only be signified through references to a cultural memory shared by Jewish readers, but the linguistic subtext and literary interplay work in a similar way, giving pleasure to those with cultural knowledge and expanding the polysemy of the text.

The embedding of a text within the text creates a conscious and involuntary refraction of a former literary identity which is regenerated with ironic variation. It is a rewriting of past texts that at once repeats and transforms, evoking a cultural revenant in the new, or, as Anna Akhmatova put it, rendering the "profound joy of recurrence," ${ }^{5}$ but also appropriating other texts, making them one's own and satisfying what Osip Mandelstam called the "yearning for a world culture."6 Mandelstam evidently regarded the writer as, first of all, a reader, and expected his readers to share a common cultural knowledge in the reading act: ". . . The vocation of reader is no less respectable than the vocation of poet" ("Звание читателя не менее почтенно, чем звание поэта"), he wrote in 1923. ${ }^{7}$ Nabokov is another instance of a Russian modernist who makes his readers play a game of hunting literary references in order to complete the text or make sense of it, although his clues are more obtuse. But then, it was axiomatic of modernism in its post-symbolist form that authors expected readers to appreciate a web of allusions that, as Mandelstam's contemporary T. S. Eliot explained in "Tradition and the Individual Talent" (1919), made the past present and brought into play a vast array of intertextual references in a Bergsonian durée. ${ }^{8}$ Similarly, Babel"s mimicking of styles and genres and literary allusions is a form of stylization that the Russian Formalist Yurii Tynianov defined as a quotation of other texts, a game that Babel"s readers have to play. ${ }^{9}$

Context is also intertext, because to refer is to engage dialogically with the surrounding ideological and historical discourse, as well as the linguistic deep structure of word, sound, and image. To refer is to recover a cultural memory which has been destroyed by history but which is available to those readers with the linguistic tools and 
cultural knowledge to decipher the coded ethnic or ideological subtext. The resulting "quotations" will inevitably conflict with other semantic associations in the text, creating humor out of semantic multiplicity and ambiguity.

The heteroglossia of such intertextuality reorients point of view, much as Mikhail Bakhtin's "another's word" (чужое слово) introduces the word of the Other in Dostoevsky's polyphonic novels. ${ }^{10}$ In Julia Kristeva's interpretation of Bakhtin's heteroglossia, intertextuality enters into a dialogic relationship with other discourses in a Saussurean sign system. ${ }^{11}$ However, the Acmeists' dialogical relationship with subtexts in Russian culture was not noticed by the Bakhtin circle. ${ }^{12}$ The interface of such dialogization works both horizontally, that is, synchronically, introducing other voices within the text and outside it, but also vertically, that is, diachronically, referencing allusions and other texts in cultural memory. In Jakobsonian terms, paradigmatic and syntagmatic axes intersect when surface meaning meets deep meaning as a result of lexical shifts and semantic association. Zholkovsky and Yampolsky sum up how the intertextuality of Babel"s stories functions:

To a significant degree, the textuality of Babel"s prose is determined by these networks of equivalence, which posit worlds of metamorphosis, transformation, and exchange. Circulation goes on not just between phrases, but also between story-line clusters [siuzhetnye bloki] within stories (particularly between the frame and the interpolated story) and between stories of different years and series. The farthest expansion of semantic and lexical transformations regularly brings in also an intertextual sphere, where at the forefront other issues and factors are brought forward arising from mutual relations with other texts.

Marc Schreurs returns us to a Bakhtinian approach by calling Babel"s technique "intertextual montage," ${ }^{14}$ which sets up a dialogical relationship between words. This bypasses the problem of intentionality in literary allusions by positing the inherent intertextuality in semantics itself which is activated by cultural memory when two different ideological or semantic discourses are heard in an utterance, provided that the original "pre-text" can be identified. As we will see, however, readers with a minority 
cultural memory could interpret the same utterance in a parallel but divergent meaning, lending the text layers of multivalence. In the skaz stories in Red Cavalry, for example, an educated standard Russian speaker would perceive the ironic representation of the values of the Cossacks, as when Balmashev vents his indignation in "Salt" ("Соль") that the women smugglers deceive them and were not raped by the boys like the other female passengers, but a Jewish reader would recognize the humor in Balmashev's mistaking of Trotsky for a true Russian with fighting spirit and Lenin for an intellectual of doubtful origins. In "Betrayal" ("Измена"), Balmashev's blatant anti-Semitism is revealed in his attack on Dr. Jawein, while in "The Letter" ("Письмо"), a Jewish sensibility would be shocked by the callous attitude to his family when the Cossack lad first asks in his letter home about his horse and then relates how his brothers caught his father and murdered him.

\section{The Russian Jewish Polysystem}

For Babel', Yiddish was not a foreign language, but mama-loshenthe "mother tongue" intelligible to most East European Jews. Babel' edited translations by Semyon Gekht of Sholom Aleichem ${ }^{15}$ and published a screenplay based on Sholom Aleichem's novel Wandering Stars (בלאנדזשענדע שטערן). ${ }^{16}$ Babel's prefaces contain a political disclaimer in which he distances himself from this ideologically unsuitable material, but Sholom Aleichem remained close to his heart for the rest of his life. The film Wandering Stars (Блуждающце звездыl, 1926) was written for the Jewish Chamber Theater (later the State Jewish Theater, GOSET), whose star actor Mikhoels was a friend of Babel', and distributed by the All-Ukrainian Film Studios (VUFKU), which had a commercial interest in the huge Yiddishspeaking audience in Soviet Ukraine and a political interest in spreading the message of communism. In Babel's version, Rachel Monko comes to Moscow in 1912 to join her lover, who ran away from home in a Volhynian shtetl and has become a famous violinist, Leo Rogdai. Rogdai allows himself to be corrupted by fame, while Rachel learns what it means to be a Jewish illegal in Moscow and spends time in a labor camp after she took the blame 
upon herself for revolutionary leaflets found in her room in a dosshouse. Interestingly, Babel' inserted into the film a brief scene of a provincial Yiddish traveling troupe in a forsaken Galician shtetl, which plays an adaptation of Jacob Gordin's The Jewish King Lear (דער אידישע קיניג ליר (1892), which was very popular in the early twentieth century. Babel' regularly attended performances of Mikhoels' State Jewish Theater (GOSET) in Moscow. ${ }^{17}$

Babel' was commissioned to edit the complete works of Sholom Aleichem for the 80th anniversary of the writer's birth in 1939; Babel' was supposed to deliver his translation of the Tevye stories by 1 February 1939. Sholom Aleichem was "Sovietized" as a classic of Jewish folk humor, though reservations were made about his bourgeois ideology, which were reflected in Babel's apologetic preface to Wandering Stars, and in the thirties he was universalized to meet the demands of an increasingly chauvinistic Stalinism. ${ }^{18}$ Babel' met Mendel Mokher-Sforim before the "grandfather of Yiddish literature" passed away in 1917 and intended to work on a jubilee edition of Mendele's works in Russian translation. ${ }^{19}$ In addition, Babel' translated from other Yiddish authors, including the Yiddish modernist Dovid Bergelson's story about a New York tenement, "Dzhiro Dzhiro" (1929). ${ }^{20}$ Nevertheless, Babel"s affinity, in spirit rather than style, with Yiddish modernists, such as Bergelson, Peretz Markish, or Der Nister (pseudonym of Pinkhas Kahanovich), remains to be investigated. Babel' shares with Sholom Aleichem a Yiddish humoristic style and, as has been observed, the common basis of Sholom Aleichem's stories and Odessa humor may explain Babel"s stylization of his Odessa Jewish characters. ${ }^{21}$ In fact, Alexander Zholkovsky has posited a tempting thematic link between Sholom Aleichem's "My First Novel" and the erotic relationship between the story-teller and his reader in "My First Fee." 22

Here Itamar Even-Zohar's theory of polysystem, drawing on the work of the Formalists Yurii Tynianov and Boris Eikhenbaum, as well as on the Tartu School of Semiotics, is useful as a way of understanding the way the trilingual culture of Russian Jewry worked. Literary systems are heterogeneous, systems within systems, which remain dynamic and develop as long as there is conflict between 
the canonical and the minor or marginal. From the 1880s up to the Bolshevik Revolution, Yiddish competed with Hebrew for canonic status as the language of Jewish culture, while Russian served for Hebrew as a non-canonical model from which translations of classics should be made. Literary polysystems renew themselves by translation and emulation, or by importing marginal texts (folklore, devices from "cheap" or popular literature, "forbidden" material and so forth). ${ }^{23}$ In the Russian Jewish polysystem, the highly stratified hierarchy of each of the cultures in contact created a fluid and paradoxical situation; the interdependence of Hebrew, Yiddish, and Russian Jewish literary texts made not only for competition and ideological rivalry between the codified cultural systems, but also for switching codes between them, when writers wrote first in one language, then in another, but also played with references to the other cultural code by "quoting" or parodying the other language. ${ }^{24}$ This literary interference resulted in semantic shifts between different levels of cultural referentiality, sometimes for comic effect, as in Tevye's liberal quotation and reinterpretation of the Hebrew Bible or Talmudic Aramaic in Sholom Aleichem's Yiddish stories. Such interference was second nature to writers like Mendele or Sholom Aleichem, and it generated a coded play of language that resisted the ravages and destruction of history. ${ }^{25}$

Polysystem theory shows the operation of dynamic changes in bilingual cultures, whose literatures are conventionally studied separately, but it can also help us understand the relation of canonic texts to marginal or popular works, as well as the cultural hierarchy of texts in a heterogeneous cultural system. It explains the process of interference when cultural or linguistic properties are transferred from one cultural system to another. ${ }^{26}$ However, in contrast to EvenZohar's broader theory of cultural contacts, I shall apply the term interference to the borrowing or "import" of linguistic and cultural components stylistically marked as "other," "subculture," or "nonstandard" in the repertoire of the socio-cultural hierarchy. The movement is usually from periphery to center, and from the marginal to the canonic (for example, Yiddishisms marking the minority outgroup), but there are cases of "prestige" cultural markers (such as French in nineteenth-century Russian at a time when Gallicisms 
were productive in the Russian cultural polysystem and served as legitimate markers of "high" cultural status). ${ }^{27}$ A partial parallel might be Chicano speech in American popular culture, and, though the analogy of Yiddish in American English is not entirely precise, a similar ironic humor is present in the linguistic confusion of the Hyman Kaplan stories by Leo Rosten.

Yiddish was also used as a macaronic device by some Soviet Jewish poets to refer to a doomed culture. A more ambivalent example is the poetess Elizaveta Polonskaia (Movshenzon) (18901969), like Lev Lunts a member of the Serapion Brotherhood, who celebrated the romantic attraction of the revolution in her Russian verse and declared her love for Russia. Yet she never forgot her origins in an assimilated Jewish family in Lodz and her love for the Hebrew bible, and in A Stubborn Calendar (Упрямый календарь, 1929) Polonskaia suddenly bursts into Yiddish when she finds herself recognized by a half-blind old beggar-woman in the alien crowd who addresses her in the "incomprehensible" language of the Jews as a pure Jewish child ("тайр идии кинд"):

\footnotetext{
И пусть ты забыла веру и род,

А ид из имер а ид!

То кровь моя в жилах твоих поет, Чужим языком говорит.
}

And though you may forget both faith and kin, A yid iz immer a yid! My blood sings in your veins, Sings in an alien voice. ${ }^{28}$

The poetess cannot evade the ethnic markers of her sad eyes and her blood, or ignore the fact that the Russian language in her blood is alien; here the interference of a "foreign" language foregrounds the conflict of cultural identities that had been submerged in assimilation. Another example is "Kol Nidre," a poem by the Imagist Matvei Roizman (1896-1973), who believed the revolution in Russia would bring about a revival of the Jewish nation. Roizman introduces into his Russian poem the Hebrew words of the Jewish credo, Hear O Israel (שמע ישראל), which closes the Day of Atonement, 
in order to identify with the Marranos (conversos persecuted by the Inquisition as suspected crypto-Jews) in a martyrology of the pogrom victims, thus making the biblical heritage of the Land of Israel and the recently spilt blood of Jews in Russian exile relevant to Russian poetry. ${ }^{29}$

Iosif Utkin is far more satirical in "The Tale of Red-headed Motele, the Tax Inspector, Rabbi Isaiah and Commissar Bloch" (“Повесть о рыжем Мотэле, господине инспекторе, раввине Исае и комиссаре Блохе", 1924-25). By blending Yiddish in his Russian rhyme and meter, Utkin reflects the cultural and ideological transformation of shtetl Jew into communist commissar. The former victim of the Kishinev pogrom can sew a shroud for the Tsar, a poetic vengeance which marks an end to the standard resignation to their fate of the powerless Jews. The Soviet critic A. Lezhnev commented that the stylization of Yiddish works only because it is in a Russian text. In the context of the October Revolution, which has signaled the death of the milieu to which it refers, it casts doubt on the credibility of the depicted Jewish world. ${ }^{30}$ The election of Yiddish to an equal, if jocular, partnership with Russian speaks for a new hopeful pride, as in Utkin's "Sweet Childhood" ("Милое детство", 1926-1933), when the boy rejects his aunt's wish to dedicate him to God and a trade, but tells his Russian comrade he is not a Yid, he is a Jew. However, Yiddish tainted as it was with the shtetl and the underworld, was swallowed up in the Russification of the urbanized Jewish professional classes, and was repressed in the reign of fear and increasing chauvinism under Stalin.

His own knowledge of Yiddish allowed Babel' to play on semantic shifts in calqued phrases in "Shabos Nakhamu," an adaptation of a Yiddish folk-tale, which appeared with the subtitle, "From the Hershele cycle" (Из цикла Гершеле), perhaps suggesting that Babel' may have intended translating more of the Hershele stories. In his Diary (23 July 1920, Собрание сочинений, II, 258), he thought of Hershele as he watched the worshippers praying in a Dubno synagogue; in the Red Cavalry story "The Rebbe," Liutov tells the rebbe that he is putting into verse the adventures of Hershele, a cultural referent which identifies Liutov as a fellow Jew rather than a marauding soldier from the invading revolutionary forces 
(though there is some irony in the rebbe calling Odessa the star of our exile and a noble city, considering the notoriety of its secular way of life; the versification of anecdotes about Hershel Ostropoler is also not exactly a holy task).

Yiddish-speaking readers would be quite familiar with the folktales about the eighteenth-century trickster Hershel of Ostropol and would have enjoyed the playful "translation" (or calquing) into Russian of typically Yiddish expressions like אַ מאַן ווי אַ מענטש" ("a husband as a man should be," literally "a man like a man"), or ער קורמיט מיך מיט צולאָגען ("he feeds me on promises"). However, in Babel"s rendition, the phrases mean one thing in Russian, another in Yiddish. Hershele's wife complains:

“У каждой жены-муж как муж. Мой же только и умеет, что кормить жену словечками. Дай Бог, чтобы у него отнялся к Новому году язык, и руки, и ноги". (Детство, 20)

"By every woman is her husband a mentsh. Mine only knows to feed his wife with fine phrases. Please God by the New Year he should lose his tongue, and his arms, and his legs." 31

Babel' is fairly faithful to the original. ${ }^{32}$ An innkeeper tells his wife that when Shabos Nakhamu comes (that is, the Sabbath after the Fast of the Ninth of Av), he will buy her a new dress and they will go to the rebbe Motale to get a blessing so they will have a boy. Hershele persuades the incredulous innkeeper's wife that he is "Shabos Nakhamu" come from the next world. Angels, we know, do not eat, but Hershele convinces the poor simple woman that since angels don't get much to eat, her relatives are much in need; she gives the starving Hershele a hearty meal, which he wolfs down like a man from the next world, and sends him off heavily laden with clothes, food and all good things for her deceased kith and kin. When her irate husband comes in hot pursuit of the trickster, Hershele realizes the innkeeper is not much smarter than his wife and leaves him stripped naked while he makes off in the innkeeper's horse and cart.

However, Babel's characteristically rich and hyperbolic imagination transforms the anecdote, and the phrases I have quoted are apparently Babel"s own invention. The comic effect of the 
linguistic interference arises from code-switching among Russian speakers (especially those who were bilingual in Russian and Yiddish), the joke arising from semantic shifts between different levels of language usage. Stylization and "import" of foreign words and phrases add spice to Russian literature and the Russian language. ${ }^{33}$ However, for Jewish readers, Yiddish, still tolerated at least in its socialist form, and Hebrew, officially proscribed as the language of religion and politically dangerous because of its association with the banned Zionist movement, reverberated with the continuity of Jewish national existence.

Stylized Yiddish identifies Jewish speakers in Babel"s stories, such as Gedali, or the rebbe in Red Cavalry who addresses Liutov with the usual greeting between Jews, “Откуда приехал еврей?" פ" פון וענן קומט אֵייד? ("where do you come from?"), here translated literally into Russian: "from where does a Jew come?" Gedali believes in the coming of Messiah and universal justice, like all devout Jews who read Maimonides' Thirteen Principles daily. The straps he winds around the narrator are the phylacteries which bind him to Judaism and the Jewish people, but they are silken, rather than leather, perhaps because Gedali is a "silken man" (אָ זיידענער מענטש), a Yiddish expression for a diligent Talmudic scholar. Gedali's words identify him as belonging to a community of learned Jews who understand what redemption means, because they too have studied the story of the Exodus from Egyptian bondage: "And we all, learned people, we prostrate ourselves and cry out loud: woe to us, where is the sweet revolution?" (“И вот мы все, ученые люди, мы падаем на лицо и кричим на голос: горе нам, где сладкая реводюция?" [Детство, 126]). Rabbi Ben-Zechariah in Sunset remarks of the man sitting next to him that he is "as long as the exile" (לאֵֵנג ווי דער גלות), that is, very tall. The contemporary Jewish reader would have recognized the bitter-sweet nuances in which Tsudechkis introduces himself in "Justice in Parenthesis" as someone who had been blessed with being born a Jew in Tsarist Russia, and therefore-almost inevitably-being a Jew, became an Odessa broker who lives on air, a luftmentsh in the Yiddish idiom for a jack-of-all-trades who goes from town to town buying and selling, literally "a man of air." 


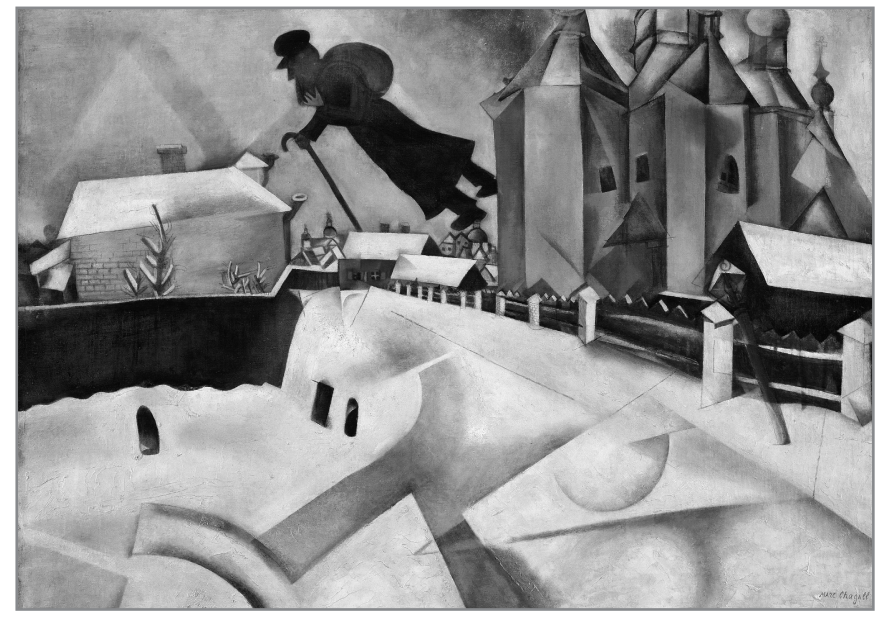

Marc Chagall, Over Vitebsk. 1915-20 (after a painting of 1914).

New York, Museum of Modern Art, New York, oil on canvas, $263 / 8$ x 36 1/2

$(67 \times 92.7 \mathrm{~cm})$. Acquired through the Lillie P. Bliss Bequest. 277.1949

(c) 2012. Digital image, The Museum of Modern Art, New York/Scala, Florence

Передо мной стоит воздух. Он блестит, как море под солнцем, красивый и пустой воздух. (Детство, 256)

Before me stands air. It glistens like the sea beneath the sun, beautiful and empty air. (Red Cavalry and Other Stories, 254; slightly revised).

And where else but in Odessa would the Menachem-Mendels of this world seek their fortune? In "Odessa," too, Babel' mentions the "people of air" ("дюди воздуха") milling around the cafés, trying to make a dime out of nothing in order to feed their families - and why, Babel' jokes, should anyone give a dime to a useless person of air? (Собрание сочинений, I, 45). Such playful use of a Yiddish subtext is familiar from Yiddish verbal jokes in Marc Chagall's paintings of this period, not least the visual pun on "luftmensh" in Over Vitebsk (1915-20), which visualizes the Yiddish idiom for living by begging, literally "he goes over the houses" ("ער גייט איבער די הי-זער ").

The literalization of the Yiddish idiom can raise laughs from Yiddish-speaking readers, and it is a key to a polyphonic Jewish reading of the text. And this is a joke Babel' apparently enjoys very much. After all, we should not take Babel"s language play too seriously as a treatise on power dynamics of Russian Jewry or 
the bourgeois respectability of gangsters. In "How It Was Done in Odessa" Benia tells stories from the history of the Jewish people during the raid on Tartakovsky, "Benia was telling stories from the life of the Jewish people" ("Беня рассказывал истории из жизни еврейского народа" [Детство, 250]), that is to say, ironically, he bemoans his hard life-מעשיות פון יידישן לעבן-and warns that the boss had better not play Rothschild or he will burn in fire. After the raid, he tells Aunt Pesia there has been a mistake, referring to the shooting of her son Iosif, but wasn't it a mistake for God to settle the Jews in Russia? Even God makes mistakes! In telling this story, Arye-Leib performs the role of Aaron to "Lisping Moses" when he speaks from on high as God spoke on Mount Sinai. In his speech at the funeral, Benia draws on Talmudic lore and Yiddish idiom to cover up his criminal complicity in the two murders by portraying this Joseph as a scapegoat for the working class. He concludes by drawing the crowd to the fresh grave of Savka Butsis, the drunken gangster wiped out for his part in the killing:

Есть люди, умеющие пить водку, и есть люди, не умеющие пить водку, но все же пьющие ее. И вот первые получают удоводьствие от горя и от радости, а вторые страдают за всех тех, кто пьет водку, не умея пить ее. (Детство, 254)

There are people who know how to drink vodka and there are people who don't know how to drink vodka, but drink it all the same. And so the former derive satisfaction from misery and joy, and the latter suffer for all those who drink vodka without knowing how to.

No less hilariously irreverent are the mock-solemn Talmudic or Yiddish-type aphorisms at Dvoira's wedding in "The King":

За стол садились не по старшинству. Глупая старость жалка не менее, чем трусливая юность. И не по богатству. Подкладка тяжелого кошелька сшита из слез. (Детство, 240)

The seating at table was not according to age. Senile stupidity is no less pitiable than the cowardice of youth. Nor by wealth. The lining of a heavy purse is sown from tears. 
Of course, the heavy purse is Eichbaum's, and it brings tears when the gangsters raid wealthy Jews. In "The End of the Old Folk's Home," Arye-Leib proceeds in typically Talmudic fashion to persuade Broidin to let the funeral guild have wood for a coffin:

Арье-Дейб начал, как всегда, с иносказаний, с притч, крадущихся издалека и к цели, не всем видимой.

Он начал с притчи о рабби Осии, отдавшем свое имущество детям, сердце - жене, страх - Богу, подать - цезарю и оставившему себе только место под масличным деревом, где солнце, закатываясь, светило дольше всего. От рабби Осии АрьеДейб перешел к доскам для нового гроба и к пайку. (Детство, 301-02)

Arye-Leib started, as always, from euphemisms, from sayings, which crept from afar to an end that not everyone could see.

He started from sayings about Rabbi Oshiah who gave all his property to his children, his love to his wife, his fear to God, what he owed to Caesar, and who left himself only a place under the olive tree which caught the sunset longest. From Rabbi Oshiah Arye-Leib proceeded to boards for a new coffin and the rations.

This might appear to be a good example of Babel"s stylization of Yiddish idiom, but the "quotation" from a second-century C.E. Talmudic sage is fake, and in fact recalls Jesus' saying "render unto Caesar what is Caesar's and unto God what is God's" in the Christian scriptures! This shows just how much Babel' created an innovative Russian prose out of Yiddish and Odessa speech, endowing them with an epic quality and a whimsical irony all of his own.

\section{The Language of Odessa}

The cafés chantants celebrated by Babel' in "Odessa" and in his two sketches "Notes from Odessa", where drag artists and con men hung out, were more popular than the literary clubs frequented by the intellectual elite, or the smart cafés, which catered for the middleclass bourgeoisie. Yet, even if they did not appreciate Akhmatova and Blok there, this was the real Odessa of Izya Kremer (1887-1956), the famous Russian and Yiddish singer, the world of eccentrics and interesting stories (Собрание сочинений, I, 48-57). It is doubtful 
whether Babel' participated in the poets' "Green Lantern" club or its successor, the "Poets' Collective," but in 1923 Babel' laid claim to an affinity between Odessa writers (including Bagritsky, Il'f, Lev Slavin, Semyon Gekht, and Valentin Kataev, among others) in a foreword to an unpublished anthology of young Odessa authors. Babel' asserted they were united by romantic dreams of exotic shores, but in reality got married and settled down:

Тут все дело в том, что в Одессе каждый юноша-пока он не женился - хочет быть юнгой на океанском судне. И одна у нас беда-в Одессе мы женимся с необыкновенным упорством. (Собрание сочинений, I, 59).

Here the whole business is that in Odessa every young fellowuntil he gets married - wants to be a boatswain's mate on an ocean liner. And our one problem is that in Odessa we get married with extraordinary stubbornness.

The paradox is that dreamy romanticism did not pay bills; recognition of talent came when these Odessites moved to Moscow or Leningrad and it was there that they contributed to the Odessa myth.

Russian as spoken in Odessa was notoriously "bad" or "ungrammatical," and, as Babel' facetiously averred in "Odessa" (1916), this made it a "very nasty place” (“Одесса очень скверный город") (Собрание сочинений, I, 43). Babel' is actually playing a familiar tune, echoing the Russian journalist Vlas Doroshevich (1864-1922), who, in an 1895 sketch on the language of Odessa, celebrates Odessites' peculiar use of Russian idiom and their carefree attitude toward the conjugation and declensions of standard Russian; such freedom, he declares, is the stuff of Odessa wit and makes so memorable the Odessites' colorful turns of phrase. ${ }^{35}$ Acknowledging the magical effect of Odessa's acacias on a Northerner, the Russian writer Kuprin complained in 1911 that the Odessites unashamedly abused the Russian language and proudly insisted on the correctness of the Odessa "zhargon."36 Zamiatin, who had high regard for Babel"s prose style, as I mentioned in the introduction, and thought provincialisms quite legitimate, was quite scathing about literary use by Southern writers of the 
Yiddish and Ukrainian that had crept into spoken Russian, "since the worst adulteration of the language has occurred in the south and particularly in Odessa." ${ }^{37}$ Deviation here is read as cultural, rather than social, deviance, but Odessa's uniquely cosmopolitan and trilingual culture demanded recognition as a "minor literature" before its demise under the detritions of war and revolution. ${ }^{38}$ Babel' and other Odessa writers turned what was originally the language of an uncultured lower class in Odessa into a literary form, which was then taken as evidence for "Odessa language" and Jewish humor, popularized by the jazz singer Leonid Utesov and the comedian Mikhail Zhvanetskii. ${ }^{39}$ Babel' stylizes Odessa idioms, grammar, and syntax, but by the time his Odessa stories appeared, these were cultural referents that were passing into memory and could signify for a Moscow reader at most a symptom of the influx of the regional, the romantic attraction of the transgressive, the folksy, and the exotic. ${ }^{40}$

The Yiddish component of Odessa's language is not surprising, given that over a third of Odessa's population before World War One were Yiddish speakers, and Odessisms have been conflated with Yiddish humor to such an extent that (notwithstanding the decimation or emigration of Odessa's Jews) Odessisms have become a kind of comic "Jewspeak." ${ }^{41}$ There is no consensus among researchers as to the status of Odessa Russian - a dialect of Russian, pidgin, a Jewish language usage/creole (a form of Jewish Russian), or a fusion of Russian, Ukrainian, and Yiddish arising from cultural contact between these groups, with interference, borrowing, and calques from Yiddish and Ukrainian, but also from Italian, German, and other languages spoken by Odessa's transient sailors, merchants, and foreign visitors. Some of its characteristics are oral (variant phonetics, irregular intonation, or non-standard grammar), and its usage in standard Russian is often anecdotal or comic. ${ }^{42}$ Unlike the wealthy Jewish maskilim who came to Odessa from Galicia in the nineteenth century and disdained Yiddish, Babel"s characters are associated with the underworld and the port, where thieves' slang, native Yiddish, and Odessa Russian mix with Ukrainian, French, and Italian. V. F. Shishov and A. A. Stetsiuchenko have analyzed the "Odessisms" of Babel"s Odessa stories and concluded that, while 
the language of the stories creates an entirely fictional world, Babel' does put into his characters' mouths Odessisms that are typical of Yiddish speakers whose Russian is inflected with German syntax or Ukrainian idioms, as well as nonstandard grammatical forms and local usage of Ukrainian words. ${ }^{43}$ Compare "Мине сдается, что у нас горит сажа" (Детство, 244; "I think something is burning") with Ukrainian мені здається. Tartakovsky's cursing Benia, "чтобы земля тебя выбросила" (Детство, 252) is apparently calqued from the Ukrainian expression Щоб тебе по смерті з землі викинуло ("may the ground throw you up after you're dead"). Yiddish speakers would easily recognize “...и вся Одесса будет от вас говорить" (Детство, 241; “...and all Odessa will talk from you")

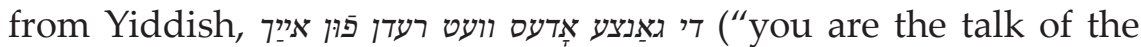
town," literally, "the whole world talks from you"). And when Tsudechkis complains, in "Liubka the Cossack," "Какая нахальства" (Детство, 266) (instead of the expected standard Russian Haxaльство), we can hear the influence of Yiddish אָזאַ חוצפּה! ("what a chutzpah!”). ${ }^{44}$

In "Elia Isaakovich and Margarita Prokof'evna," Eli Hershkovich tells the Russian prostitute,

“У нас в Одессе ... за десять рублей вы имеете на Моддаванке царскую комнату". (Детство, 17)

"By us in Odessa ... for ten rubles you have in the Moldavanka a room fit for the Tsar."

Doroshevich was of the opinion that such usage of the verb imet' originates from German, ${ }^{45}$ yet, as an Odessa Jew, Eli, like Tsudechkis, talks in the idiom of a Yiddish-speaking savvy broker. Together with underworld slang (blat) that also draws on Hebrew and Yiddish ${ }^{46}$ (such as бранжа, "a specialized trade," in "Justice in Parenthesis" and "The Father"), the Odessa gangsters speak an Odessa Russian that combines calques from Yiddish with their own idiolect. In "The King," the young man tells Benia,

...я имею вам сказать пару слов. (Детство, 239, 244) ${ }^{47}$

...I have a couple of words to say to you. 
The expression nара слов ("a pair of words") is found also in dialect and standard Russian and, idiomatically, in Ukrainian, for example in the mouth of a Kuban Cossack in the Red Cavalry story "Salt" (Детство, 172), as well as Epikhodov in Chekhov's Cherry Orchard (Act II). When Benia tells us all Iosif saw in his life was "nара пустлков" (Детство, 254; "а couple of trifles" [Red Cavalry and Other Stories, 253]), this may be an Odessism that lost its irony in passing into colloquial Russian as an expression for nothing worth speaking of, a piece of cake. ${ }^{48}$

Odessa Russian peppers the Odessa stories with its pungent aphorisms. Benia says little, but what he says, Froim Grach tells us, is savory ("смачно" [Детство, 247]). Yet often it's hard to tell where the odesskii zhargon ends and where Babel"s rich imagination begins. ${ }^{49}$ When Benia Krik applies to the Odessa mafiosi for a job, the interview goes like this,

- Кто ты, откуда ты идешь и чем ты дышишь?

- Попробуй меня, Фроим, - ответил Беня, - и перестанем размазывать белую кашу по чистому столу.

- Перестанем размазывать кашу, - ответил Грач, - я тебя попробую. (Детство, 247)

"Who are you, where are you coming from, and what do you breathe with?"

"Try me, Froim," replied Benia, "and let's stop spreading white kasha on a clean table."

"Let's stop spreading kasha," replied Grach, "I'll give you a try."

"Spreading kasha over a clean table" apparently mixes up two separate Russian idioms, for convoluted talk (размазывать кашу) and making trouble. ${ }^{50}$ Asking what kind of person you are, "what do you breathe with?" ("чем ты дышишь?"), is recognizably an Odessism, which appears also in Bagritsky's Lay of Opanas (Дyмa nро Onaraca, 1926), a ballad whose hero is a Jewish Bolshevik. ${ }^{51}$ Odessa-born Anna Akhmatova writes in a 1913 poem, "We will not drink out of the same glass" ("Не будем пить из одного стакана"): 
Ты дышишь солнцем, я дышу луною,

Но живы мы дюбовию одною. 52

You breathe the sun,

I breathe the moon,

But we live by love alone.

We might note that the expression "чем человек дышит" ("what a person breathes with") is also a stylized Yiddish expression in "Shabbos Nakhamu" (Детство, 25). In any case, Babel"s stylization of Odessa Russian characterizes the speech of Odessa gangsters; it is not characteristic of his Childhood stories. Yet, this is what is remembered when a Russian-speaker thinks of Odessa Russian and the way it has entered standard Russian. By contrast, the Odessisms of Jabotinsky's well-to-do businessmen in The Five sound different and far less memorable..$^{53}$

The Moldavanka's reputation for "Jewish" criminality in the eyes of middle-class Russians and Ukrainians gave the poverty-stricken, predominantly Jewish area an aura of adventurous promiscuity, where Jews were kings and brazenly pushed permissibility beyond the bounds of bourgeois social norms. ${ }^{54}$ The criminality of Jewish Odessa is actually a myth not borne out by the statistics, but, faced with an anti-Semitic and corrupt regime, Jewish entrepreneurs and activists in pre-revolutionary Odessa did tend to overstep communal and civic norms to get what they wanted and did not flinch from violence..$^{55}$ The myth was nevertheless strong in the popular imagination and in literature. The underworld was in any case a popular theme of Soviet Russian prose in the twenties, cultivated as literary material in Benjamin Kaverin's End of the Gang (Конеи, хазы, 1926), Leonid Leonov's The Thief (Bор, 1927), and in verse Vera Inber's “Vas'ka Svist Caught in a Trap” (“Васька Свист в переплете") and Il'ia Sel'vinski's "Motia Malkhamoves" ("Мотькэ Малхамовес"). ${ }^{56}$ It was Leonid Utesov who helped to popularize the Odessa underworld songs that had been performed in the cabaret acts of Odessa's cafés in 1917-1923, and he was much criticized (as was Babel') for romanticizing the bandits. ${ }^{57}$ Here, we see that Yiddish and Odessisms are given primacy in the cultural hierarchy, which was not true in pre-revolutionary Russian and Russo- 
Jewish writing, in which Yiddish generally had to be mediated or translated through the prism of perceived Jewish cultural inferiority, if not dismissed as despicable "zhargon" unworthy of any language status. ${ }^{58}$ After the February Revolution, a non-stereotyped Jewish milieu and a Jewish language became not just legitimate, but an entry card into a newly emancipated cultural status. In the postrevolutionary period, non-standard and dialect language was ideologically justified as characterizing proletarian speech, and the playful use of Odessisms by Bagritsky or Babel' was not unusual in the demographical and cultural flux of Soviet Russia.

Well may Benia Krik complain to Aunt Pesia, in "How It Was Done in Odessa," that God made a mistake in settling the Jews in Russia, where they were tormented worse than in hell, though behind this plea, worthy of Sholom Aleichem's Tevye, we can't help noticing it is one of Benia's own gangsters who has shot her beloved Iosif! With bathos drenched in Yiddish humor, the gangsters fire in the air in "The King," because if you don't fire in the air someone might get killed (Детство, 241), and in "How It Was Done in Odessa," "Jewand-a-Half" Tartakovsky complains to Benia as he cries over the death of Iosif Muginstein that he has picked a fine fashion-killing live people (Детство, 252). And of course Muginstein has to be shot in the stomach - for that is the meaning of his name in Yiddish ("stomach-stone") - and he dies from a "narishkeit," a "stupidity" in Yiddish ("глупость"). ${ }^{59}$

Нужны ди тут слова? Был человек и нет человека. Жил себе невинный холостяк, как птица на ветке, - и вот он погиб через глупость. Пришел еврей, похожий на матроса, и выстрелил не в какую-нибудь бутылку с сюрпризом, а в живого человека. Нужны ди тут слова? (Детство, 250-51)

Are words needed here? A person was and is no more. An innocent bachelor lived like a bird on a branch, and he dies from something stupid. Along comes a Jew looking like a sailor and shoots not at some bottle in a fairground stall but at a living person. Are words needed here?

The laughter is carnivalesque and refers us to a world of inverted social hierarchies, where Ben-Tsion Krik is "King" and raids the police-station. 
In Odessa, there was an intrinsic sense of Jewish identity that allowed a cultural hegemony despite the Jew's social and legal disabilities. Benia's Odessa speech celebrates a sovereignty that is more imagined than real but challenges the social order in which the Jew is powerless and discriminated against. The violence of history is met with violence when Benia's gang counterattacks the Slobodka pogromshchiki during the fake funeral of the local magnate, Ruvim Tartakovsky. However, power lies in language, not muscle, and Babel' has found a way of creating in his Russian prose a language that is confidently Russian Jewish in its cultural outlook, without the hyphen of pre-revolutionary Russo-Jewish polemics, which generally regarded Yiddish as a "zhargon" of a backward, traditional Jewry.

Rachel Rubin has gone so far as to assert that Babel' has himself become a linguistic "gangster" by translating illicit criminal violence into literary attacks on language. ${ }^{60}$ Actually, Benia is terrifyingly laconic, frightening out of their wits anyone who talks to him, as Tsudechkis tells us in "Justice in Parenthesis," and Babel"s own mania for laconism hardly suggests criminal assaults on language or a verbal bravado. The writer who stammers on the page and cannot shout in public (to paraphrase Arye-Leib) may envy Benia's colorful synaesthetic costume and sexual exuberance, which he shares with those other men of violence, the Cossacks in Red Cavalry. The intellectual with specs on his nose and autumn in his heart is an ironic figure of parody, distanced from anarchic criminals. Not that the gangsters are all Jewish (they are not), but Babel' presents their narrative as an intrinsically Jewish experience in Russian prose. As Ruth Wisse has noted, it is through assimilating Jewish experience and Jewish language to the literary discourse of the host society that modern Jewish culture defined itself in the twentieth century and responded to both persecution and acculturation. ${ }^{61}$

\section{Reference/ Referentiality}

If Babel' must be understood in a diachronic chronology of cultural history, the synchronic context is no less crucial for us to understand the contemporary literary and political discourse in which Babel"s sketches and stories first appeared. The revolutionary turmoil of 
1917-1918 saw a flood of periodicals in an unprecedented variety of political and cultural diversity before the crackdown on the opposition press in July 1918. While Babel' contributed to Gor'ky's Menshevik newspaper Novaia zhizn' (New Life) before it was shut down, three pieces by Babel' appeared in the Social-Democrat Petrograd newspaper Vecherniaia zvezda (Evening Star) in March 1918. Two were the "Notes from Odessa," but the first was "Shabos Nakhamu," an adaptation of a Yiddish folk-tale which would appear at first sight to have little relevance to the immediate dangers of war and starvation in besieged Petrograd.

"Shabos Nakhamu," of course, had particular significance for readers versed in Jewish tradition, for it was the name of the Sabbath following the Ninth of Av, the fast day commemorating the Destruction of Jerusalem. On that Sabbath, consolatory passages are read from the prophet Isaiah, which promise redemption from exile and captivity. After pogroms and the destruction of war and revolution, the Jews of Russia certainly had need of hope in redemption. As the war fronts disintegrated, the headlines of Vecherniaia zvezda screamed that Russia's apocalypse was near. The Germans took Kiev, Odessa fell and was briefly recaptured; antiRevolutionary conspiracies and Civil War filled the news items. Poems by Emmanuil German and M. Levidov echoed op-eds that declared the twentieth century had opened disastrously for Russia. In the 6 March 1918 edition, Osip Mandelstam wrote

На страшной высоте блуждающий огонь, Но разве так звезда мерцает?

Прозрачная звезда, блуждающий огонь, Твой брат, Петрополь, умирает.

A wandering flame at a terrifying height, Surely this is not how a star twinkles? A translucent star, a wandering flame, Your brother, Petropolis, is dying.

Blok's The Twelve (Двенадияать), published in February 1918, gave a christological aspect to revolution, which emerges out of the elemental forces of the "black evening" ("черный вечер"), while the Social Revolutionary and Social Democratic press voiced the 
apocalyptic mood of the twilight of Petersburg in the cold winter of 1917-1918 that promised no rejuvenating spring. ${ }^{63}$ Mandelstam is concerned for the death of a cultural heritage, of Russia and the Petersburg literary tradition, as well as his own fate as a poet. ${ }^{64}$

For Russian readers in starving Petrograd, who were probably as cold and hungry as Hershele proverbially was, the social and political analogy was not difficult to discern. The dying star was threatened by German advances before the conclusion of the armistice and was soon to be besieged by the Whites; the same year the capital was transferred to Moscow. Apart from stories and poetry, translations in the pages of Vecherniaia zvezda included Henri Barbusse's Under Fire (Le feu, 1916), one of the best known anti-war novels, which concludes that the mutilated frozen corpses in the trenches will not advance the cause of progress one bit. But if the translation of the Hershele story claimed literary value for a Yiddish text, raising it above a "Jewish" joke, the humor arising from the different readings of "Shabos Nakhamu" by Yiddish-speaking readers is indicative of the free movement between Russian and Jewish worlds of writers and artists who could, for the first time, express themselves freely on Jewish themes in Russian cultural venues. Liberated from the shackles of Tsarist restrictions and persecutions, those who stayed willingly in Russia looked forward to a flowering of a cultural symbiosis, as well as a cultural renascence, that had begun in 19101912 but had been disrupted by the First World War. Those hopes were pinned on a new social justice in the millennial vision of Isaiah and other Hebrew prophets, whose words seemed to be coming true as Allenby marched into Jerusalem and the Balfour Declaration offered a National Home for the Jews. In Russia, however, those hopes were to be cruelly disappointed. By the second half of the nineteen-twenties, the Jewish avant-garde in art and literature was forced into ideological conformity. The cult of Stalinism gradually outlawed all experimentation, and secular Yiddish literature itself came under suspicion of "nationalism." Nevertheless, as we shall see in the next chapter, Jews were adept at referring under adverse political conditions to their repressed culture, and the trilingual polysystem of Jewish culture in Russia lent itself to subtle referentiality and playful interference. 
"There are two sides to Odessa, the spiritual and the earthly" (Jabotinsky).

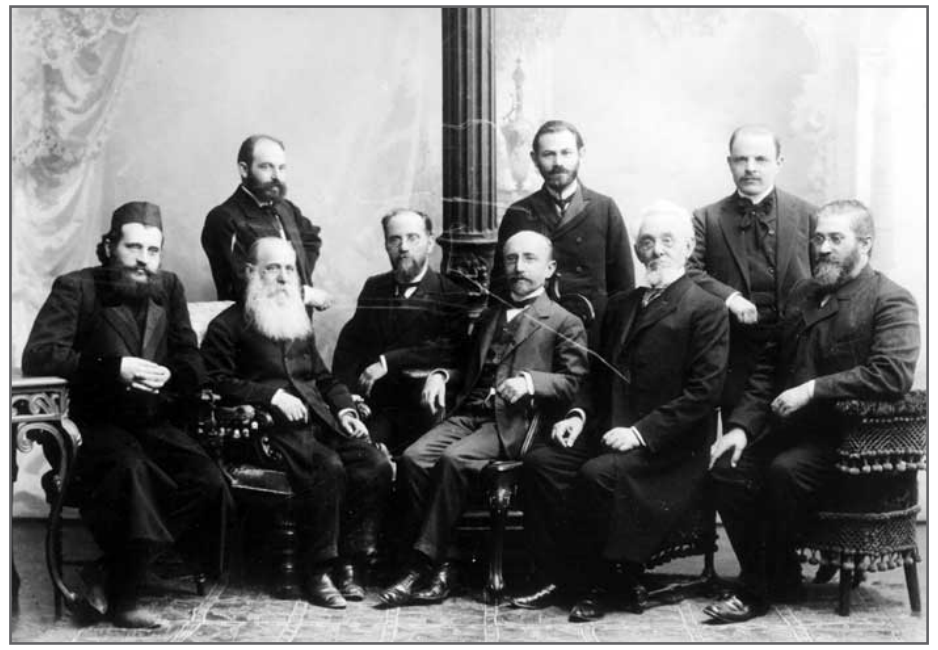

The Wise Men of Odessa

Chernowitz, Lilienblum, Ravnitsky, Akhad-Ha'am, Mendel Mokher-Sforim, and Levinsky; standing: Borokhov, Klausner, Bialik

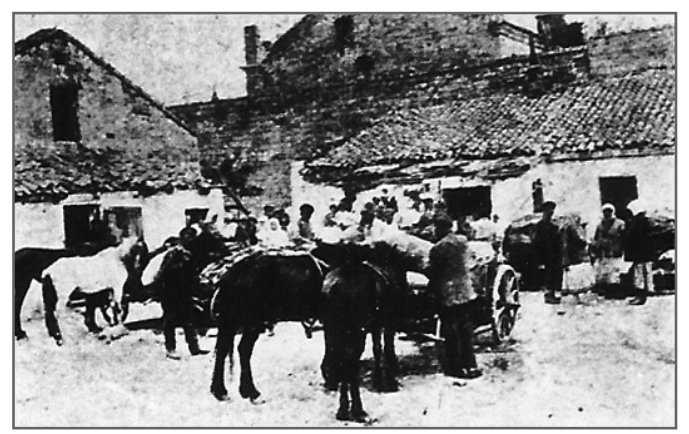

Odessa tavern, reputedly Liubka the Cossack's (ca. 1925) 
BABEL', Bialik, AND Others

\section{The Wise Men of Odessa}

The Odessa in which Babel' grew up was a thriving center of modern Jewish culture in three languages. ${ }^{1}$ Founded in 1794, Odessa grew at a phenomenal rate, encouraged by the drive to colonize the Black Sea shores of the Ukraine. As a relatively new city, it was thoroughly cosmopolitan, and was more open than any other Russian city. Its French mayor, the Duc de Richelieu, helped shape the city's Mediterranean look, with the Italian architecture of its Opera House and other public buildings, including the grand staircase leading to the seafront, and encouraged the growth of a multiethnic population, which included Russians, Ukrainians, Moldavians, Greeks, Italians, and Jews. This made Odessa in its boom years all the more attractive for Jews coming from the Pale of Settlement, where they were hemmed in by legal and economic restrictions and had little access to Western culture. In Odessa, there were no traditions of the shtetl which might inhibit modernization and secularization, and there was no need to shed Jewish identity in order to prosper and thrive. Odessa offered all the conditions for developing distinctively new forms of Jewish intellectual life, especially as Austrian Jews from Galicia brought with them the ideas of the German Jewish enlightenment. ${ }^{2}$ In 1841, a group of them founded their own synagogue, named for the town of Brody in Galicia, the Brodsky Synagogue, later rebuilt in 1863 in a fabulous Italian-Gothic style, where Pinkhas Minkovsky (1859-1924) and the famous choir of 60 boys could be heard every Sabbath. This was the same cantor and choir unlucky enough to attend Iosif Muginstein's funeral in "How It Was Done in Odessa." 
Cover page of Den'

(Odessa), June 1869

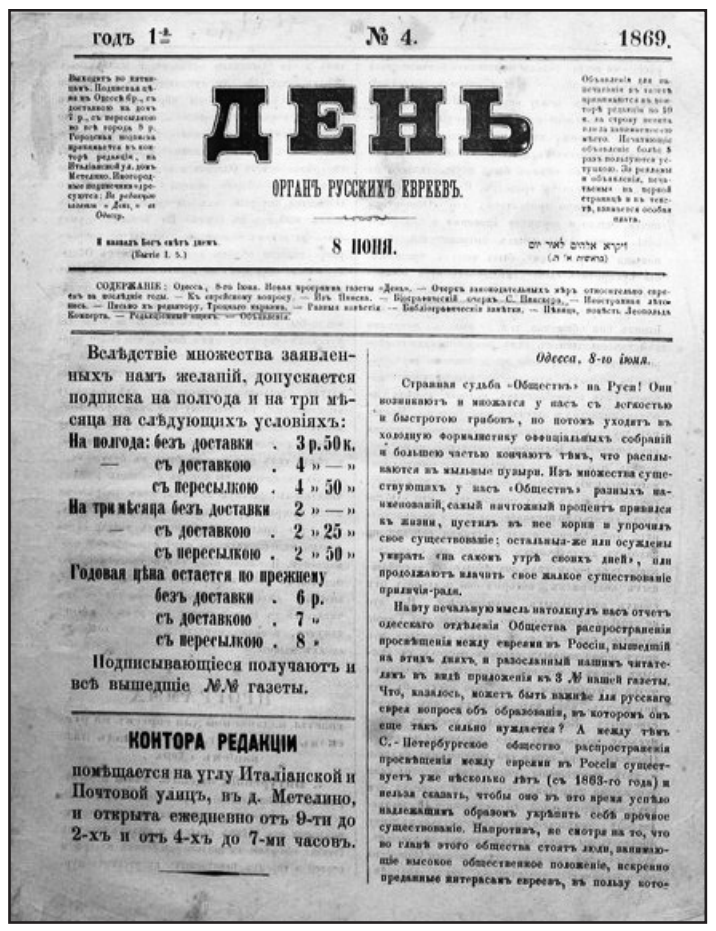

Odessa was unusual among cities of the Russian empire in that Jews were not segregated and could advance into the professional and business classes in a cosmopolitan multiethnic society. ${ }^{3}$ A group of Russian-Jewish writers catered for the assimilated Russian-speaking Jews, but also polemicized on behalf of civic rights and against what they perceived as the backward ways of traditional Judaism. Osip

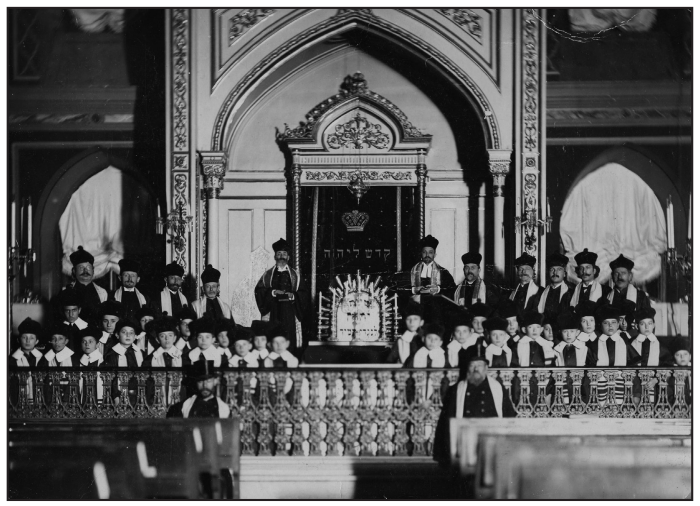

Pinkhas Minkovsky and choir, Brodsky Synagogue, around 1910. From the archives of YIVO Institute for Jewish Research, New York 
Rabinovich, a lawyer turned novelist, was one of the most prominent figures associated with the Russian-Jewish press and with the Haskalah movement in Odessa. Russian-speaking Odessa was open to upwardly mobile Jewish professionals like Osip Rabinovich who moved freely in the Russian world of letters. ${ }^{4}$ Notwithstanding inter-ethnic violence and Black Hundred anti-Semitism, Jews mixed among Odessa's different nationalities while maintaining a sense of their separate identity. This made acculturation easier, and, by the turn of the century, there was a Russo-Jewish literature centered in St. Petersburg and Odessa, where Vladimir (Zeev) Jabotinsky was writing in the local Russian press and Semyon Yushkevich was satirizing the Odessa Jewish milieu.

Odessa was the home of Moshe Leib Lilienblum, a follower of Moses Mendelssohn, the leader of the Haskalah movement in Germany, and Leo Pinsker whose Auto-Emancipation made a deep impression on the generation of Russian Jews after the 1881 pogroms. This is where, encouraged by the brief spirit of reforms, the Russian Jewish press began with Rassvet (1860-1861), Tsion (1861-1862), and Den' (1869-1871), besides the Hebrew periodical, Hamelits (1860). Khaim Nakhman Bialik fled the yeshiva in Volozhin in 1890 for Odessa, where he joined the ranks of the Wise Men of Odessa, Peretz Smolenskin, Alexander Zederbaum, Simon Dubnov, Simon Frug, and Mendel Mokher-Sforim (S. Y. Rabinovich). Mendele and the Hebrew poet laureate Bialik developed the classical Odessa style in Hebrew literature, the "nusakh Odessa." ${ }^{5}$ Along with Warsaw and Vilna (the "Jerusalem of Lithuania"), Odessa became a major center of Hebrew publications. Hebrew was now being resurrected as a modern, secular culture that drew on mishnaic strands of Hebrew fused with neologisms and innovations, although few spoke the language besides the proto-Zionist enthusiasts in their private clubs. In Odessa, Hebrew was reborn. Ben-Ami (pseudonym of I. M. Rabinovich), the critics Ravnitsky and Klausner, and the historian Dubnov, among others, were prominent in the debates over the Jewish national revival. From 1881, a nucleus of writers grew around publishing houses and periodicals, mainly associated with the Cultural Zionism of Akhad Ha'am (pseudonym of Asher Ginzberg). ${ }^{6}$ The Yiddish writer Sholom Aleichem came to live 
in Odessa in 1891-1893, though in his fiction Odessa seems to act mainly as a foil to the shtetl. When the luckless luftmensh Menakhem Mendel describes how easy it is to do business on the stock market sitting in Fanconi's, we see through his foolish delusions and recognize Odessa for what it is, a city of swindlers and scoundrels, where a Jew can pawn his last shirt and nobody will help him. To "live like God in Odessa," as the Yiddish proverb went, only confirmed the truth of the other popular Yiddish adage, that for seven miles around Odessa the fires of hell were burning. ${ }^{7}$

Many starry-eyed youngsters journeyed from provincial towns to try their luck in Odessa, hoping that a great writer, such as Bialik or Mendele, would launch them into literature and fame. In their memoirs, Odessa is painted in glorious colors. The sea, the boulevard cafés, and the literary evenings are described as a Jewish cultural Mecca in a nostalgic retrospect by Yiddish writer Peretz Hirschbein, ${ }^{8}$ Hebrew novelist Ya'akov Fichman, and the great critic Ravnitsky himself. ${ }^{9}$ The Hebrew novelist and essayist Eliezer Shteynman attributed Odessa's uniqueness to the leisurely atmosphere, the seriousness of conversations, the balmy climate, and the proximity of Odessa's Black Sea resorts. ${ }^{10}$ Odessa is remembered in a more historical perspective by Shmuel Ussishkin, son of the well-known Zionist leader, in his posthumous memoirs. ${ }^{11}$

Actually, the city was already in decline by the outbreak of the First World War, which brought thousands of impoverished refugees who were fleeing from eastern Europe, or had been deported from the front by the Tsarist authorities. By the time of the February Revolution, the Jews made up almost half the population of the city. The end of restrictions on Jewish residence rights and particularly the lifting of censorship and the ban on the Hebrew press, introduced during the war, resulted in a new spurt of frenzied cultural life. From 1917 to 1919, there was an extraordinary flourishing of publications in Hebrew, Yiddish, and Russian, reflecting the wide variety of political positions from the Jewish workers' party, the Bund, through revolutionary socialists, to Zionists. The Zionists were perhaps the strongest group and, following the Balfour Declaration and British victory in the Middle East, they turned their attention to immigration to the land of Israel 
through Odessa's sea port; however, many fled to Berlin or other European cities.

Conditions in Odessa during the revolutionary years of blockade and famine deteriorated from turmoil into chaos and anarchy. The city changed hands no less than nine times and suffered pogroms under the Whites; only in February 1920 did the Bolsheviks retake the city. The Bolsheviks tolerated only a secular Yiddish culture under increasingly strict Party control and were quick to close down independent Jewish cultural activity, mainly through the Evsektsiia, the Jewish arm of the Communist Party, though the last Zionist cells were not liquidated till the end of the twenties. In 1921, through the intercession of Gor'ky, Bialik and a group of Hebrew writers were allowed to leave Russia; they eventually settled in Tel Aviv, where they contributed to the construction of a national Hebrew culture. A chapter in Jewish cultural history had come to an end.

It is tempting to see Odessa as a transcultural space where Hebrew and Yiddish minor modernism emerged against the background of a thriving artistic and literary center in three languages (Ukrainian came a little later). However, even before war and revolution intervened, the relations of the marginal and the canonic, or periphery and center, did not quite match Deleuze and Guattari's paradigm of a deterritorialized and decentered literary movement. ${ }^{12}$ Moreover, as Shachar Pinsker has pointed out, the young writers who created a new modernist style in Hebrew fiction and experimented with miniatures or novellas that blended eroticism with tales of urban alienation shunned the closed clique of the Wise Men of Odessa, who controlled the publishing houses and journals; moreover, they abandoned the Odessa "nusakh" as well as the cultural Zionism of Akhad Ha'am for modernist form. Brenner, Gnessin, Fichman himself, did not stay long in Odessa, and it did not leave its mark on the modernist map of Hebrew literature, with the possible exception of Ya'akov Rabinowitz's Summer Resort (נווה קיץ, 1934) and Eliezer Shteynman's Esther Khayut (אסתר חיות, 1922), a novel written in Warsaw about the effect on a young woman and her sister of the smart life of Odessa's cafés. ${ }^{13}$ The Hebrew writer and First World War veteran Avigdor Hameiri (1890-1970) has, however, left an account of the turmoil in Odessa 
during the Civil War, written in fragmentary newsreel style, recording the coldblooded murder of Jews, the starvation and terror, as well as the requisitioning during the first days of Soviet rule, arrests of Zionists, and ruthless repression of Hebrew culture. ${ }^{14}$ It was left to the modernists in Russian-Babel', Il'f, and, of course, Jabotinsky - to portray Odessa for posterity; but then Odessa was no longer a center of Jewish culture, nor indeed a literary center, and was turning into a rundown provincial Ukrainian backwater.

\section{Babel's Shy Star}

After his return in 1905 from Nikolaev, where the family had been living since 1898, Babel' would likely have heard Bialik read his poetry and lecture; the years 1905-1911 were the most fruitful in Bialik's writing. Babel' certainly knew enough Hebrew to approve the Hebrew translations of Red Cavalry stories in the short-lived Soviet Hebrew journal Breshit, which means Genesis (בראשית, 1926), about which I will have more to say later. Babel"s generation would have known by heart many of Bialik's poems, particularly the Kishinev pogrom elegy "In the City of Massacre" ("בעיר ההריגה", 1904), which inspired many to join the local Jewish Defense League (as the boy in Babel"s story "First Love" imagines doing). This was a poem that drew on biblical Hebrew prophecies, but reversed the poetic paradigm of lamentation and challenged the covenantal tradition which had sustained Jewish communities through centuries of catastrophe. ${ }^{15}$ Its questioning of the manliness of the pogrom's male victims, who looked on from their hiding places while their women were raped, might explain, in the view of Ruth Wisse, ${ }^{16}$ the emasculation of Babel"s characters as well (Uncle Shoyl in "Story of My Dovecote," or Il'ia Bratslavsky in "The Rebbe's Son"). The view of Bialik and his generation that Russian Jewry was doomed is, moreover, reflected in Babel"s play Sunset (3akam, 1928).

Babel's strong-armed henchman, the Odessa gangsters were familiar in modern Hebrew and Yiddish literature as the ba' $a \mathrm{guf}^{17}$ who feared neither police nor pogromschiki. Such were the tough guys on Sholom Asch's Kola Street, or Bialik's Arye Ba'al Guf. They represented a new pride in Jewish identity and a fearless indepen- 
dence that answered centuries of persecution, not with assimilation, but with national revival and widespread support for the Zionist movement. Reb Israel's family on Kola Street are not exactly mafiosi, but their prowess is the mainstay of the community when it is in danger, while the son's dovecote is the subject of a battle with a rival dove fancier that reminds us of the boy's wish to raise doves and the fate of his pigeons in a pogrom in Babel"s "Story of My Dovecote." Babel' wrote that story in the 1920s, but was describing the formative effect of the traumatic events of 1904-1905 from the retrospective vantage point of his generation's response to anti-Semitic violence.

The contemporary Jewish readers of the Hebrew poets Bialik or Mendele (who began writing in Hebrew, switched to Yiddish, then returned to Hebrew), and Sholom Aleikhem were attuned to the playful intertextuality of Yiddish and Hebrew, which often parodied or inverted the meaning of familiar biblical verses or Talmudic phrases, that were already enriched with multiple resonances by their reworking through the ages, especially among the newly rediscovered Hebrew poets of Muslim Spain. Such referentiality measured the distance between the traditional Jewish home and the acculturated, enlightened Jews who could appreciate the full irony of the secular context of modernity. For Bialik this was the measure of poetry in Modern Hebrew. This distance measured a revolution that, in Benjamin Harshav's reappraisal of Even-Zohar's theory (discussed in chapter two), brought into being a secular polysystem that transformed religious values and codes, the semiotic system of the old traditional world that was fast vanishing in Soviet Russia; now definitions of Jewish identity were worked out according to new ideological demands and new social realities. ${ }^{18}$ Contemporary Jewish readers who had grown up before the Revolution would have easily deciphered the "double book-keeping" of Babel"s Red Cavalry stories in the context of a new polysystem in which Hebrew was a repressed class enemy and a secret code by which Jews who had severed their ties with their Jewish identities recognized their collective affinity with an officially disavowed ancestral past, silenced beneath a discourse loyal to the Bolshevik Revolution and the Party's nationalities policies. 
Babel"s generation, which had grown up speaking Yiddish, but were native speakers of Russian and might have varying competence in Hebrew, was becoming less familiar with the prayer book and with shtetl ways as acculturation took hold and many Jews moved away from the ruined, impoverished shtetls to the big cities to take advantage of rapid upward social mobility and economic stability. For these young intellectuals, Russian became the language of modernity and revolution. They were further distanced from biblical and traditional sources by the need to identify with communist internationalism and the Russian revolution. Intertextual allusions nevertheless unlocked a secret code known to the initiated who had grown up before the Revolution, but which was lost a generation later when assimilation and Stalinist terror erased the last cultural institutions of Yiddish and Judaism. ${ }^{19}$ Even the most fervent and hardened Jewish Bolsheviks knew how to read between the lines, and the many former Zionists and ex-Bundists or Mensheviks and Social Revolutionaries who joined the ranks of the Bolsheviks after Kronstadt (when all political opposition was repressed and the Reds were the only significant force fighting antiSemitism) still had fresh collective memories of Jewish suffering in the pogroms not just in Tsarist Russia, but very recently during the Civil War.

In Babel"s Red Cavalry story "Gedali," for example, interference of a Jewish language (stylized Yiddish) and reference to Jewish texts (Maimonides, Rashi) refer to a condemned culture. In "Gedali," Liutov looks around Zhitomir on a Friday evening for "the shy star" ("я ищу робкой звезды" [Детство, 125]). The "shy star" tells him the Sabbath has commenced and Jews will go to the synagogue to pray. This is a referential sign of a way of life ruined by pogroms and war. The narrator recalls his grandfather's volumes of Ibn Ezra, the medieval Spanish Jewish bible commentator, and weaves memories of his grandmother lighting Sabbath candles, shielding her eyes as she chanted the prayers as if she were telling fortunes. The enchanted waves on which his child's heart rocked were the waves of the Talmud, commonly referred to as a sea. This bittersweet return to the Jewish past bears remarkable similarity to that of Bialik's wandering intellectual in "On the Threshold of 
the Study House" ("על סף בית המדרש", 1894), who returns alone to the ruined shtetl which he had abandoned for the secular world of the city, only to find everything dead and rotting. The difference is that the attraction of the wind or light of enlightenment has been replaced by the red star of Bolshevism.

Just before sunset, Liutov finds Gedali locking up his Old Curiosity Shop, a Dickensian reference that evokes the old-fashioned romance of a by-gone age. ${ }^{20}$ In his diary for 3 July 1920 (June in the published version, which is clearly an error), Babel' does not record the name of the Jewish storekeeper with whom he had tea and who wished there was one good government (Собрание сочинений, II, 223). Yet there is a reference to the destruction of Judea in the name of Gedaliah, whose assassination around 585 B.C.E. marked the end of Jewish sovereignty after the destruction of the First Temple. The dialogue with Gedali opens a double perspective on the historical dimensions of the situation, as well as indicating the narrator's split loyalty to the Jewish past, and to the revolution which has helped destroy it. The intertext could be read by anyone who had read Bialik in the Hebrew original, or in the various Russian translations by Jabotinsky, Briusov, Viacheslav Ivanov, Sologub, and others, which were doubtlessly familiar to Babel'. To return in memory to the "rotted Talmuds of my childhood" ("истлевшие талмуды моего детства" [Детство, 125], a phrase missing from later editions and from Complete Works), is to return to the "rotting faded green parchments" ("גוילים בלים וירוקים ירקבו בחבית") of childhood memory in Bialik's "On the Threshold of the Study House." It is to return to the grandfather's Jewish bookshelf, to the dusty ancient tomes of the rotted Talmuds of the Jewish cultural past, and to seek comfort in the starry night above the cemetery in Bialik's "Before the BookCupboard" ("לפני ארון הספרים", 1910):

Вы помните? Бывало, бейт-га-мидраш

Оденет тьма; все разошлись давно,

И в тишине предела-я один;

Дрожа, слетает с уст модитва дедов,

А там, в углу, близ вашего ковчега,

Мерцает тихо вечная лампада. ${ }^{21}$ 


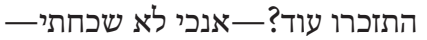 \\ בעלית קיר, בתוך בית-מדרש שומי שומם. \\ אני הייתי אחרון לאחרונים \\ על-שפתי פרפרה ומתה תפילת אבות. \\ ובפנת סתר שם, על-יד ארונכם, \\ לעיני דעך כליל נר התמיד.
}

\begin{abstract}
Do you remember? There was once a Study House Enveloped in darkness, everyone departed long ago. And in the silence, I was alone, Trembling, my forefathers' prayers dropped from my lips, And there, in the corner, near your cupboard, Splutters your Eternal Lamp.
\end{abstract}

The lamp is the "ner tamid" (eternal flame in the Temple in Jerusalem, or before the Ark housing the Torah scrolls in synagogues), but here the "cupboard" also refers to the Jewish bookshelf and the grandfather's dying culture and religious faith, abandoned by the enlightened intellectual youth who has forgotten the language of the Study House and in his melancholy despair looks to the stars for an answer.

The star had inspired Bialik with romantic longing, but it also evoked the mystical pining of the Shekhinah, as in "Sunset" ("עם דמדומי החמה", 1902). The star was, in addition, a guide through the despair of exile and alien culture, as in "A Lonely Star" ("כוכב נידח", 1899), where the poet prays to the star for his soul to be enlightened:

Озари же дух мой, опаленный срамом

Блуда по чужбинам и по чуждым храмам. ${ }^{22}$

האר אפוא, כוכב, נפשי הנואשה

מעבודה זרה ומגלות כוכב,

O star, enlighten therefore, my soul, despairing From idolatry and harsh exile.

In both Bialik and Babel', reference to the collective memory of destruction calls on cultural heritage and collective identity that the returning Jewish intellectual has lost. In "Gedali," the star is the 
object of the uprooted wandering Jew's nostalgic search for Jewish values - for Jewish tea and the pensioned-off God, which can't be had where orphans are crying. Liutov finds the "shy star," when Gedali takes him to the rebbe's on a Friday night in "The Rebbe," though later he returns to the bright lights of the propaganda train and the revolutionary future.

Like Heine, Bialik and Babel' were aware of the messianic significance of the Sabbath eve, symbolized in the Sabbath Queen or Bride, which has a central place in the Sabbath liturgy. Bialik's attempt to reconcile tradition and modernity was later affirmed by the Gedali-like "yes" to the queen Sabbath in his modern sabbath hymn, "The Sabbath Queen" ("שבת המלכה"); for Babel"s generation, the sabbath and other Jewish traditions were the price paid for the revolution's promise of "first-class rations" for every soul. However, whereas in Babel"s story the search for the shy star is a call to a lost cultural memory, the prayer to the "shy stars" ("הכוכבים הצנועים"), in Bialik's “One Summer Evening" ("היה ערב הקיץ",1908) is uttered in the sacrilegious and hedonistic context of Bialik's irony: the young man is lured from his Jewish home and spiritual values by the wanton eroticism of a Hellenistic culture (ever since the Maccabbees the epitome of the corrupting, hedonistic non-Jewish world). In the Hebrew of Bialik's poem, the term describing the stars (הצנועים) can mean both shy and modest, so that in this intertext, Babel"s "робкая звезда" reads all the more ironically as a star that beckons Liutov, a cultural sign of a dead Jewish past for which he yearns.

If Bialik responds to the imagery of Russian symbolism and reinvents modern nature poetry in the holy tongue, ${ }^{23}$ Babel"s modernist prose in Red Cavalry sets romantic summer nights in the corpse-strewn fields of Volhynia. In any case, to allude to Bialik, however obliquely, is nonetheless to speak in a "hidden language" (to adapt Sander Gilman's phrase) ${ }^{24}$ that in turn remembers the intertext of Hebrew poetry through the ages. It is to look to the renascence of Jewish cultural identity before the October Revolution from the retrospect of repression and loss of the original cultural referents.

As in "Alone" ("לבדי", 1902), Bialik's assimilated intellectual sees little but dark despair in shtetl Judaism in "On the Threshold of the 
Study House". The new spirit (or "wind") has carried away the young generation, attracted by the "light" of the secular enlightenment; the return comes when all is dead or dying, as in Bialik's "Upon My Return," a poem whose Hebrew title ("בתשובתי") plays on the Hebrew term for religious repentance. "On the Threshold of the Study House," dated the ninth day of the Hebrew month of Av, 1894 (the fast day for the Destruction of Jerusalem), was written after the closure by the Tsarist authorities in January 1892 of the famous Volozhin yeshiva, where Bialik had studied. Bialik can be said to be writing out of both personal and national bereavement, yet his attitude toward the past remains typically ambivalent. Two decades and a world war later, Liutov revisits Zhitomir, a town forever associated with Bialik's childhood, and finds the Jewish shtetl ruined and doomed. His remembrance of his own grandfather and grandmother is more nostalgic, perhaps because there can be no "return." Now the Bolshevik Revolution has claimed the loyalty of the Russian-speaking Jew, and there is no place in the new order for the Jewish past or its traditions.

Liutov's dilemma would have been familiar to readers of Bialik. Like the uprooted Jewish intellectual (talush) of turn-of-thecentury modern Hebrew literature, a cousin of Russian literature's "superfluous man" (лищний человек), the Pechorins and Bazarovs, he is torn between two worlds, "the Jewish world which he had left with no possibility of return, and the new world," the world of Russian culture, which rejected him, leaving him "isolated, dejected, and uprooted." ${ }^{25}$ The "uprooted" is a term taken from the title of a 1904 story by I. D. Berkowitz, and also appears in the work of Berdichevsky, Schoffman, and Gnessin against the background of disillusion after the 1904-1905 pogroms and frustration at the absence of an outlet for the wave of nationalism that swept East European Jewry. The question asked by M. Z. Feierberg in Whither? (לאן? had turned his back on ibn Ezra and Maimonides, but had not found a new world? This question now found a cruel expression of despair in the ex-Bundist Russian Army deserter Yosef Khaim Brenner's account of the attempt to resettle the land of Israel. His Breakdown and Bereavement (שכול וכישלון, 1920) tells of a Russian 
Jewish intellectual's displacement and disillusion, his impotence and insanity. This was the book that Kafka's Hebrew teacher, Puah Bentovim, gave him and whose title gave Kafka such troublehow could the Zionist dream be expressed in breakage and failure? ${ }^{26}$

The year of publication of Brenner's pessimistic novel was the year Babel' joined Budenny's First Horse Army in the Polish campaign, where he witnessed the destruction of the Jewish communities in Volhynia and Galicia. There he met an enthusiastic Zionist called Akiva Govrin, who has left a rather spurious memoir of this encounter, in which Babel' declaims Bialik and takes an eager interest in Modern Hebrew literature, as well as expressing admiration for Jewish youth who were training in agricultural work. ${ }^{27}$ Babel' records, in the entry for 25 August in his 1920 Diary, a meeting in Sokal' with an outspoken Zionist youth, "ein angesprochener Nationalist" (Собрание сочинений, II, 313), yet Babel"s own assessment of the aspirations of Jewish youth in Galicia and Volhynia seems to be limited to brief references in the Diary to Jewish men and women who left good Jewish homes to join the Revolution, or an ironical description in the drafts of the Red Cavalry stories of Jewish "midgets," who enlisted in the Red Army because of their convictions (Собрание сочинений, II, 363). It should be remembered that, from summer 1919, the Bolsheviks enlisted Jews from a number of political parties, from the Bund to the left Zionist Po'alei Tsion, who were ready to fight against the Whites, mainly in response to the savage pogroms sweeping the Ukraine but also out of socialist solidarity. The Jewish volunteers did not always feel welcome, however. Units consisting mainly of Jews, it was felt, might reinforce the impression that the Soviets were fighting for the Jews, and, despite Trotsky's urging that Jews should be enlisted, the First Horse Army found it difficult to absorb Jewish fighters, since anti-Semitism was so deep-rooted, especially among former soldiers of Denikin's routed forces who had joined the Bolsheviks. 


\section{Visiting the Cemetery}

The articles Babel' wrote for the front-line newspaper Krasnyi kavalerist under the pen-name of Kirill Liutov included an account of a pogrom that called on the Red soldiers to avenge the victims. ${ }^{28}$ Vengeance, however, was usually denied to the Jews. It is surely no accident that two stories of vicious Cossack vengeance should flank "Cemetery in Kozin" ("Кладбище в Козине"), a poetic vignette of the graves of unavenged Jewish victims of Budenny's Cossack predecessor, the same Khmel'nitsky who waged war in this region against the Poles and massacred a number of Jewish communities. The pogroms which swept the Ukraine, Belarus, and Galicia in 19181920 claimed some 210,000 lives. ${ }^{29}$ Shtetl Jews who had greeted the Reds as saviors from the Poles and the Whites were soon relieved of their delusions (as well as their goods and property), but were left with a simple choice of Reds or Whites: between life or death. ${ }^{30}$

The traditional Hebrew elegy suggested resignation and faith; justice for victims of crusades and pogroms was left to Divine vengeance. The "lachrymose conception of Jewish history" (in S. W. Baron's formulation) was still being expressed in responses to the pogroms of 1918-1920, which understood Jewish history as an endless progression of catastrophe. ${ }^{31}$ In Bialik's major poem on the atrocities, "In the City of Massacre" ("בעיר ההריגה", 1904; translated by Jabotinsky as "Сказание о погроме"), the poet is summoned to the cemetery only to be commanded to be hold his tongue and witness the terror in silent horror. Babel"s "Cemetery in Kozin," in the spirit of the post-Kishinev generation, emphasizes collective memory, memory of rabbinical dynasties and of the unavenged victims of four generations of persecution. As an unspoken commentary, "Cemetery in Kozin" is indeed well-placed halfway through the Red Cavalry cycle, between two tales of particularly harsh Cossack revenge. The ending echoes the Jewess's cry at the close of "Crossing the Zbrucz," when the sleeping Jew is revealed to be the corpse of a pogrom victim. The knowledgeable reader might have smiled sadly, recalling Bialik's similarly despairing cry of "until when?" in his pogrom poem, "On the Slaughter" ("על השחיטה"1903), which asked when the killing would stop, and 
which recorded the poet's outrage that no vengeance could avenge the blood of the victims: Why has death not spared the Jews once?

$$
\begin{aligned}
& \text { Проклятье,-кто местью за ужасы воздал! } \\
& \text { За кровь, за убийство младенца,-отмщений } \\
& \text { И дьявол не создал! }{ }^{32}
\end{aligned}
$$

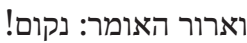

$$
\begin{aligned}
& \text { נקמת כזאת, נקמת דם ילור נקור ילד קטן }
\end{aligned}
$$

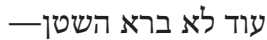

Who cries Revenge! Revenge! - accursed be he!

Fit vengeance for the spilt blood of a child

The devil has not yet compiled... ${ }^{33}$

In the Soviet period, pogroms and anti-Semitism could only be presented as part of a class struggle under the Tsarist regime, yet we can see in "Cemetery in Kozin" a mute testimony to injustice that is informed by Bialik's angry response to unspeakable atrocity in the framing of Babel"s story and in its intertextual rereading of the post-Kishinev lament in Hebrew poetry. As in Marc Chagall's "The Cemetery Gates" (1917), the October Revolution has not brought redemption to Russian Jewry and Ezekiel's prophetic promise of the resurrection of the dead has yet to be fulfilled. ${ }^{34}$

The dialectic of Liutov's stormy and ancient imagination continues throughout Red Cavalry, as we journey across the heartland of East European Jewry that had been battered by pogroms and deportations, war and revolution, and has now turned into a battleground between Poles and Bolsheviks. Throughout, Liutov is ironically unable to solve his identity crisis or resolve the contradictions between the violence of the October Revolution he follows and the humane values of his Jewish past he has abandoned. Bialik addresses the dusty ancient scrolls when he recalls the dead Jewish past (in "Before the Book-Cupboard"), but Liutov, in addressing himself in "The Rebbe's Son" to a Russian by the name of Vasily, effectively distances any Jewish viewpoint through the naming of a Russian addressee, presumably the ruthless political commissar who tells his story in "Konkin." Liutov recalls the Friday evening at the rebbe's and tells the story of Il'ia Bratslavski, whom 
he first saw there. Il'ia is Liutov's alter ego, yet the cultural referents in Il'ia's last possessions make a strong statement of the failure of Hebrew Communists to wed Judaism and communism:

\begin{abstract}
Здесь все было свалено вместе - мандаты агитатора и памятки еврейского поэта. Портреты Ленина и Маймонида лежали рядом. Уздоватое железо ленинского черепа и тускдый шелк портретов Маймонида. Прядь женских волос была заложена в книжку постановлений шестого съезда партии, и на полях коммунистических дистовок теснились кривые строки древнееврейских стихов. (Детство, 229)
\end{abstract}

Here everything was dumped together-political pamphlets and the commemorative booklets of a Jewish poet. Portraits of Lenin and Maimonides lay side by side. Lenin's nodulous skull and the tarnished silk of the portraits of Maimonides. A strand of female hair had been placed in the resolutions of the Sixth Party Congress, and in the margins of communist leaflets swarmed crooked lines of Hebrew verse. (Red Cavalry and Other Stories, 226-27; translation slightly revised)

These impossible contradictions rain down on Liutov, who receives Il'ia's last breath as a brother. The first edition of Red Cavalry closes with Il'ia's futile death, impotent and forgotten. Robert Alter calls this a quintessential response in a transition period of Jewish culture to the chasm between two worlds, recalling Berdichevsky, but aestheticized into what W. B. Yeats called "a terrible beauty." ${ }^{35}$

\title{
Genesis: The Fate of a Hebrew Communist
}

In this context, it is significant that "The Rebbe's Son" and other Red Cavalry stories, as well as "Line and Color," were selected for the Hebrew communist journal Bereshit (1926), in a Hebrew translation by Moshe Khiog (1895-1968; pen-name of Grigori-Tsvi Plotkin, né Abramson, who had taken his strange pseudonym from a novel by the Danish author Herman Bang, possibly William Høeg, the decadent protagonist of Bang's first novel Generations without Hope [Haabløse Slægter], which he could have read in Russian translation); the Hebrew translation was proofread by the author himself. The only translations in the volume, Babel's stories sum up the 
dilemma of Jews who wished to combine the ideals of the Hebrew prophets and the October Revolution, while other contributors naïvely believed they could write of the new life in biblical Hebrew without taking the path of Bialik. These real-life Il'ia Bratslavskys, like Shlomo-Ya'akov Nepomniashchi, apparently a Cheka agent, ${ }^{36}$ believed that the contradiction discernible in Il'ia Bratslavsky's last effects between Maimonides and Lenin could be resolved by rejecting the bourgeois past. Eliezer Shteynman wrote a manifesto called "The Hebrew Communist," published in Odessa in 1919, before leaving storm-battered Russia in 1921. "How they have all collapsed!" he thundered, "The self-righteous cowards-the ones who tied the fate of ancient Hebrew culture to the standards of the bourgeoisie, the aggressive, oppressive exploiters." ${ }^{37}$ By 1924, Shteynman and many like him despaired of realizing the vision of the prophets in communist Russia.

Despite the tolerant attitude of the Commissar of Education, Anatoly Lunacharsky, towards minority cultures, by 1919 Hebrew had been virtually outlawed as the language of the Jewish bourgeois and clergy, despite the fact that a number of Hebrew journals promoted socialism. The flurry of Hebrew publications after the February Revolution did not last long. After the October Revolution, Stiebel took his journal Hatekufah to Warsaw, where there was a free press and a large readership. The Hebrew poets who got together in Moscow and Kharkov were young adventurers who believed in expressing themselves in their ancient tongue, and did not generally see themselves as Zionists, but as "Hebrews," as Yocheved Bat-Miriam (who later made a name for herself as a poet in pre-state Israel) put it. ${ }^{38}$ The Hebrew Communists imitated Blok or Maiakovsky in verse that voiced enthusiasm for communist dogma, and their poetry had little to do with the land of Israel or Jewish affairs. ${ }^{39}$

Breshit appeared with the assistance of a representative of the Palestine Communist Party in Moscow, Yosef Barzilai, and through a subterfuge brought about by a couple of crazy idealists, Moshe Khiog and the Trotskyite Shimon Trebukov, who wrote as "Haboneh." Khiog, the editor, penned a strident call to rally to the communist cause and embrace the Soviet future; he cited 


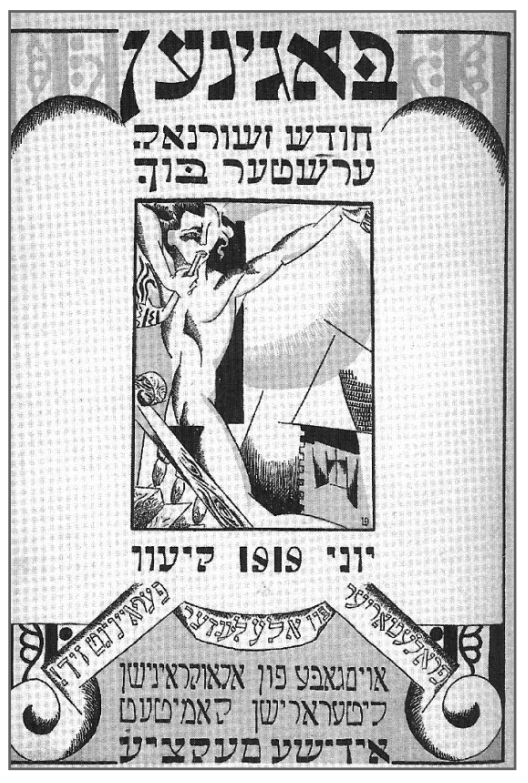

Chaikov, Baginen, Kiev 1919

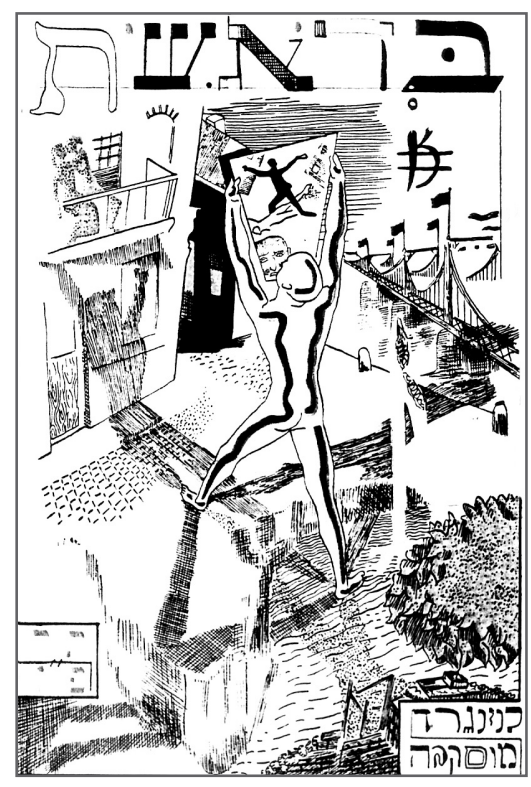

Chaikov, cover of Breshit, 1926

Berdichevsky's search for a path, rejecting that of Akhad Ha'am and Bialik, and, in lines that resound with Liutov's taunting of Gedali, declared that the October Revolution had "opened our eyes and ... they have never closed." ${ }^{40}$ Haboneh wrote an enthusiastic review of a Hebrew novella by Khaim Hazaz, From Here and There (מזה ומזה), that had appeared in Hatekufah in 1924, in which Haboneh endorsed the destruction of the old shtetl and the triumph of communist militants who looked to a new society based on universal justice, without any sympathy for what had been destroyed in the Sovietization of Jewish life. Indeed, as will be seen in chapter six, the debate in Hazaz's novella, part of a trilogy, between the shtetl's old Jews and the militant Jewish commissar chimes in with the ironic duel of Liutov with Gedali in Red Cavalry. ${ }^{41}$ Breshit appeared with the censor's approval, despite enormous bureaucratic hurdles and technical problems, such as the fact that the journal had to be printed in Berlin because of difficulties printing Hebrew in the Soviet Union, where it was denounced by the Yiddish-speaking Evsektsiia, the Jewish section of the Communist Party, who controlled the printing presses. 
Iosif Chaikov's futuristic design for the front cover recalls the one he did for a Kiev Yiddish journal, entitled Baginen (Beginnings, 1919), and expresses a similar hope for a new universal Soviet future in the modern city. Chaikov, a graphic artist and sculptor trained in Paris, was associated with the Kiev Kultur-lige, a group of avant-garde Jewish artists founded in spring 1918, which included Natan Al'tman, Issakhar-Ber Rybak, Boris Aronson, and others. Its publishing house brought out a thirty-four page collection of Babel"s stories in Yiddish. ${ }^{42}$ Later, Chaikov went over to conformist work designing posters that lauded Stalinism. The post-revolutionary hopes for a new society, which avant-garde Jewish artists invested in the Kultur-lige and elsewhere, were soon eclipsed by communist control of cultural organizations - among them the Kultur-ligeand the gradual repression of free artistic expression, culminating at the end of the 1920s in the Markish and Kvitko affairs in Yiddish literature and the Zamiatin and Pil'niak affairs in Russian literature. On the Jewish street, the internationalist dogma silenced voices still suspected of Jewish "nationalism."

What hope do Babel"s stories represent, for the post-Kishinev generation, for some realization of the prophetic vision of a just society? What hope do they carry for Soviet Jews to express social and cultural identity as Russian-speaking Jews, or as Jewish intellectuals who might move freely between Russian and Yiddish culture? Babel"s own view was clearly more conflicted than the bombastic hopes of the editors of Bereshit for a new Soviet Jew building a future for all. In his 1920 Diary, Babel' relates how he pretends to be a Russian, which does not fool local Jews, and he apparently witnesses in silence the Cossacks' pillaging of Jewish religious articles, looting, and the desecration of the sabbath on the eve of the Ninth of $\mathrm{Av}$, the fast that commemorates the destruction of the Temple. Historical sensibilities resound here, in a clear reference to a major paradigm in Hebrew poetry, as we will see later in this book. Babel', an assimilated Odessa Jew, does not conceal his identification with the collective memory of persecution and the experience of the destruction of the shtetl.

An ambiguous statement on the outcome of dual identity, Jewish and Soviet, Hebrew and communist, is found in the ending of "Karl- 
Yankel" (1931). This story tells of one of the public trials of Jewish ritual circumcision that were held in the Soviet Union until the end of the twenties as part of the campaign against religion; but it is also a trial that marks the end of the ethos of Jewish Odessa. The baby, named for Karl, for the father of Marxism, by his Communist father, concerned for his standing in the Party, and circumcised as Yankel, named in Yiddish for the Jewish patriarch Jacob, by the religious grandmother, represents that impossible fusion of the old and the new that we saw in Il'ia Bratslavsky. A Kirgiz woman nurses the child, in parody of the Brotherhood of the Soviet Peoples, and promises he will grow up to be an air pilot (the spirit of a Soviet future!). But the narrator thinks of his own childhood, growing up on the streets of Odessa:

Из окна летели прямые улицы, исхоженные детством моим и юностью - Пушкинская тянулась к вокзалу, Мало-Арнаутская вдавалась в парк у моря.

Я вырос на этих улицах, теперь наступил черед Карл-Янкеля, но за меня не дрались так, как дерутся за него... Мало кому было дела до меня... (Детство, 317).

From the window I saw running into the distance the streets traversed by my childhood and youth-Pushkin Street led to the railway station and Lower Arnaut Street ended at the park by the sea.

I grew up on these streets, now it was the turn of Karl-Yankel. But nobody fought over me as they are fighting over him... Almost nobody bothered about me.

Pushkin Street clearly speaks for the Russian literary tradition and the cultural identity of the author, but 9 Lower Arnaut Street is where Bialik lived until he left Russia in 1921. The duality of the narrator's cultural identity is an anachronism in the 1930s, since so many of the new Soviet Jewish intelligentsia had opted for "Pushkin Street," and identified with Russian culture in their revolt against the Jewish past and accommodation with the communist future. The illuminated aura of Pushkin at the end of "Di Grasso" grants the boy from Jewish Moldavanka some kind of epiphany ${ }^{43}$ (though, unlike Bagritsky and other Soviet Jewish idealists, Babel' 
himself never rebelled against his assimilated bourgeois father). "Karl-Yankel" closes with an ironic hope that the new generation will be happier than he was:

- Не может быть, - шептал я себе, - чтобы ты не был счастлив, Кард-Янкель... Не может быть, чтобы ты не был счастливей меня... (Детство, 317).

"It cannot be," I whispered to myself, "that you would not be happy, Karl-Yankel... It can't be that you wouldn't be happier than me...."

Ostensibly, the story mouths the clichéd slogans of the Party line, but the ambivalence of the authorial position is unmistakable: the Galician Hasidic rabbis come to see Judaism on trial; the old attorney for the defense, Lipking, makes a ridiculous figure in a Soviet court; the mohel (ritual circumciser) Naftula reminds the public prosecutor that he too was circumcised and born Zusmanall of this emphasizes the fate of Jewish Odessa and a final end of a thriving literary center that could be referenced only in the subtext.

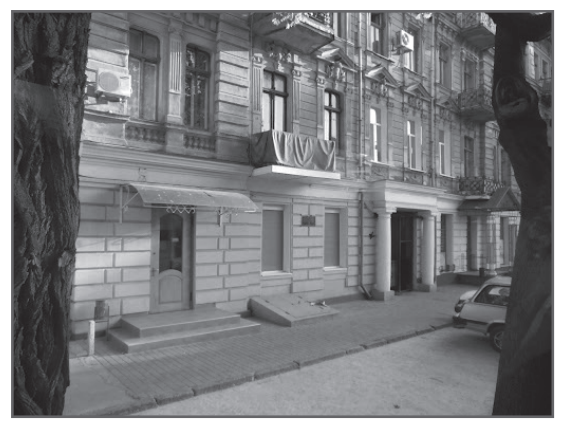

Bialik's house,

Lower Arnaut Street, Odessa

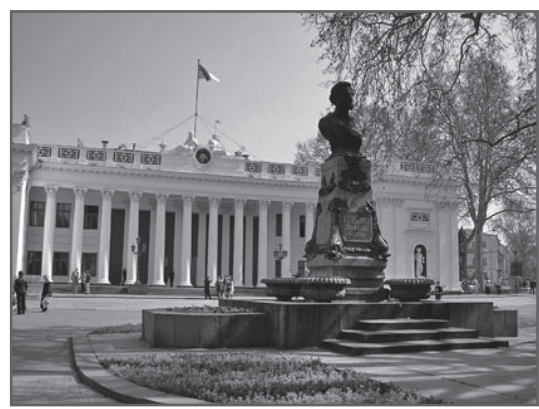

Monument to Pushkin, Odessa 


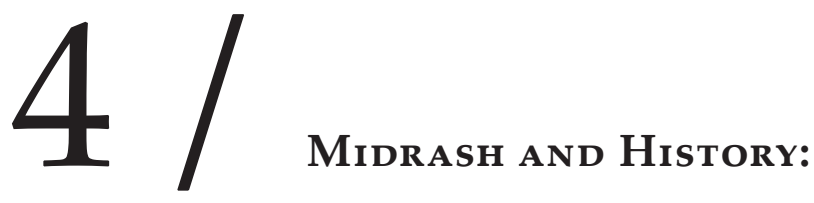

\section{A Key to the Babelesque Imagination}

\section{Myth as History}

Myth in Babel"s fiction gives an illusion of the epic while mocking it, and reads unorthodox interpretations and essential truths into history. For Babel', the myths of history and religion were a subtle medium for allegorical parallels, as well as ironic allusions to a moral message. This is an essentially midrashic approach to history, following the ancient Jewish storytelling tradition that imaginatively elaborates on biblical and historical narrative, usually for exegetic or homiletic purposes, and playfully draws on intertextual, verbal, and semantic associations. Often new, contemporary meaning is introduced into the reading of familiar stories, or biblical verses are given unexpected levels of meaning that dramatizes biblical figures as human. As Daniel Boyarin has demonstrated, midrash, the biblical metacommentary that forms part of Talmudic lore, is fundamentally intertextual and sets up a coded duality between the exegetical text and the quoted or referenced passage. When a textual moment is felt to be awkward, what Michel Rifattere terms "ungrammaticality" points to gaps that provide the key to decoding through another text. ${ }^{1}$ The midrashic mode informs the Jewish imagination at times of cultural repression (such as under the Romans or the Tsars), and characterizes the way the canon of Jewish literature has developed and renewed itself. There is something we might call midrashic in Babel's view of history. 
We may find a key to Babel"s midrashic view of history in the art of the Polish painter in Red Cavalry. The story "Pan Apolek" introduces us to the first direct encounter in the book with Western art and culture. "Pan Apolek" has been read as a key to a Christian reading of Red Cavalry, ${ }^{2}$ but in fact its attitude toward Catholicism is ironically ambivalent and repeats Russian stereotypes of the Poles and of Jesuits (who are seen as sly and conspiratorial). The story presents a picture not only of a rich Western culture unfamiliar to backward, provincial Russia, but also of ancient enmity towards Russia and a satanically heretical religion. ${ }^{3}$ In the diary which Babel' wrote while on the Polish-Soviet front in 1920, and which served as raw material for the later Red Cavalry stories, there is no mention of a Polish painter, but in the ruins of Catholic churches and in the home of the priest Tuzinkiewicz with its ancient tomes and Latin manuscripts, Babel' stumbles upon the Catholic mystery.

Pan Apolek is himself an instance of the playful use of myth that demonstrates an aesthetic credo and a singularly non-Marxist understanding of history as cyclical and repetitive. Apolek is christened Apollinarius, which identifies him with Apollo, Greek god of poetry and music, representative, in direct opposition to Dionysus, of the intellect and of civilization. ${ }^{4}$ Apollo has a confused history in Greek mythology, but out of his many functions it is as Apollo Smintheus (associated with a mouse, possibly because of a historical confusion with a dialect word for mouse) that Apolek is recognized. Apolek wanders the earth with two white mice tucked behind his shirt, here an epithet for the archetypal victim. Apolek lacks his classical forebear's lyre, but he does have the blind musician Gottfried from Heidelberg to play to him, ${ }^{5}$ and it is in Western Europe, to whose influence Babel', as an Odessa Jew, was naturally predisposed, that we must seek clues to Babel"s hagiography of Pan Apolek. ${ }^{6}$

The narrator first comes across the art of Pan Apolek in the story "Pan Apolek." In his exposition to the story the narrator takes vows to the aesthetic ideal of Apolek's art, a "gospel hidden from the world," and writes with hindsight that the saintly life of Pan Apolek "went to his head like old wine"; it later transpires that Apolek is a drunken heretic. The invented aesthetic model of the Polish painter 
expresses, in characteristically visual imagery, Babel"s concept of art and history that juxtaposes the real and the ideal. The narrator chats to Apolek about the romantic past of the Polish gentry and about Luca della Robbia, the fifteenth-century sculptor who created a spiritual beauty in his church art, but the treatise on Apolek's artistic ideal ends with the narrator returning to the gruesome reality of his plundered Jews; the story concludes with his loneliness, homelessness, and impossible idealism:

По городу слонялась бездомная луна. И я шел с нею вместе, отогревая в себе неисполнимые мечты и нестройные песни. (Детство, 120)

The vagrant moon trailed through the town and I tagged along, nurturing within me unfulfillable dreams and dissonant songs. (Complete Works, 222)

The first of Apolek's chefs-d'oeuvre to be exhibited is his portrait of St. John. This is evidently a portrait of St. John the Baptist, for his head lies on a clay dish after his execution, but it also portrays St. John the Apostle-Evangelist, for out of the mouth slithers a snake, a reference to the legend in which a snake saved St. John the Apostle's life by extracting the venom from a poisoned chalice. The dead St. John's face seems familiar to the narrator, and he has a presentiment of the truth: the severed head is drawn from Pan Romuald. Pan Romuald, we recall, was the treacherous viper of "The Church in Novograd" ("Костел в Новограде"), the runaway priest's assistant who was later shot as a spy. His venomous character is introduced in that story by the image of his cassock snaking its way through the dusk, and his soul is merciless, like a cat's. Incidentally, the association of Romuald with the serpent and the cat makes him both the natural and mythological enemy of Apollo the mouse god and slayer of the python. The monkish eunuch Romuald, who would have become a bishop had he not been shot as a spy, stands in direct contrast to the aesthetic and doctrinal heresy of Apolek. Pan Robacki, who pours anathema on the heretical painter in "Pan Apolek," is also likened to a cat, and his "grey ears" help to identify him with the "gray old men with bony ears" in "The Church in Novograd," all senile attributes of a dead world opposed to the life-giving, joyful art of Apolek. 
The narrator finds himself half-way towards solving the riddle of Apolek's iconography when he spots the Madonna hanging over the bed of Pani Eliza, the priest's housekeeper, for it is she who is portrayed as a rosy-cheeked Mary. Apolek first came to Novograd-Volynsk thirty years before, as the narrator relates in his apocryphal rendering of the coming of this questionably holy fool who sparked off a long and bitter war with the established church. Like Michelangelo in the Sistine Chapel, Apolek climbs along the walls of the Novograd church and paints into his frescoes a psychological, though ahistorical, truth. The lame convert Janek is depicted as Paulwho was disabled with blindness in the story of his conversion (Acts 9:1-19). The scene of the stoning of the adulteress (compare John 8:3-11) is referred to as the stoning of Mary Magdalene, who is appropriately depicted as the Jewish prostitute Elka, for all three are fallen women. Apolek's heresy is to elevate ordinary folk into mythical heroes with the haloes of saints, while bringing the divine, supernatural myths down to the level of comprehension of mortals. In the same way that Renaissance painters flattered their patrons, Apolek wins a smile and a glass of cognac from the old priest who recognizes himself among the Magi, and he peoples the homes of the local population with peasant Josephs and Marys. For an extra ten złoty their enemy can be depicted as Judas Iscariot. Apolek even offers to paint the narrator as St. Francis of Assisi, with a dove or a goldfinch on his sleeve, an ironical reference to the horse's head insignia on the sleeve of the narrator's Red Cavalry uniform.

Apolek realizes in ordinary folk with all their human vices their potential for spirituality and epic deeds. Above all, Apolek brings out the aesthetic beauty of human flesh, which he colors like a "tropical garden." Lush and sensuous, Apolek's paintings beatify mundane existence as if mythical, while the mythical is revitalized to reveal hidden truths. Apolek's scenes of the nativity resemble Babel's impressions of the religious paintings of Rembrandt, Murillo, and the Italian masters which he saw in a Polish church in Beresteczko. The hint at the pre-Christian and pagan origins of the Church in the "Chinese carved rosary," which the Novograd priest holds as he blesses the infant Jesus in Apolek's painting, is also clear in the description in Babel's diary entry for 7 August 1920: 
великолепная итальянская живопись, розовые патеры, качающие младенца Христа, великолепный темный Христос, Рембрандт, Мадонна под Мурильо, а может быть Муридьо, и главное - эти святые упитанные иезуиты, фигурка китайская жуткая за покрывалом, в малиновом кунтуше, бородатый еврейчик, лавочка, сломанная рака, фигура святого Валента. Служитель трепещет, как птица, корчится; мешает русскую речь с польской, мне нельзя прикоснуться, рыдает. Зверье, они пришли, чтобы грабить, это так ясно, разрушаются старые боги. (Собрание сочинений, II, 287)

magnificent Italian art, pink Paters rocking the infant Jesus, a magnificent mysterious Christ, Rembrandt, a Madonna after Murillo or perhaps a real Murillo, and the main thing is these pious, well-fed Jesuits, a weird Chinese figurine behind the veil, [Jesus is] a bearded little Jew in a crimson-colored cloak, a bench, the shattered shrine, the figure of St. Valentine. The beadle, shivering like a bird, cowers, mixes up his Russian with Polish, I mustn't touch, he sobs. The beasts, they came to ransack. It's very clear, the old gods are being destroyed. (Babel', Complete Works 432; translation revised).

The scene of the ransacking of a church, from which this extract is taken, is transformed into the desecration by the Cossacks in "At St. Valentine's Church" ("У святого Валента"). This transformation tells us much about Babel"s recognition of the power of myth to make supernatural or historical events relevant to the present day, an aesthetic concept which the author places at the center of the art of that mythical myth-maker, Pan Apolek, and which is modeled on the masters of the Renaissance. The result is an unexpected historical perspective in which the historical is seen as real and the real as legendary.

This brings us into the realm of midrash, the homiletic rereading and supranarration of Jewish history and lore. In Red Cavalry, Jewish legends of the desecration of the Temple are made appropriate to the persecution of East European Jewish communities in 1918-1920. For example, the Babylonian Talmud (Gittin 56b) relates how Titus entered the Temple and committed an obscenity on the Scroll of the Law. Then he drew a sword and pierced the curtain in front of the Holy of Holies in the middle of the Temple. By a miracle blood 
oozed out and he started to shout that he had killed the God of the Jews. (There is another version in the midrashic compilation Vayikra raba 20, 5.) In Babel"s story "At St. Valentine's Church" the curtain falls away to reveal Jesus, a bleeding, suffering, persecuted Polish shtetl Jew, who frightens a Cossack soldier in the PolishSoviet war whose comrades and ancestors have persecuted so many Jewish communities. In an excised passage, the Cossacks commit an obscenity with the brigade nurse Sashka in this holy place, and since all this takes place against the background of a further destruction of the Jewish community, the parallel with the Destruction of the Temple springs to the Jewish reader's mind. The historical parallel is, however, confounded with the appearance of Jesus as a suffering shtetl Jew, an image which was quite familiar in contemporary avant-garde Jewish art and poetry, as in Chagall's Calvary (1912). Time collapses and historical memory is reenacted in the present in a relentless cycle of persecution and pogroms.

Apolek's reweaving of the Gospelstories, likeBabel"sownimagery, transposes the sacred and the profane, rendering the supernatural grotesquely earthy and the everyday almost superhuman. As the fence and cemetery watchman Witold declares in Apolek's defense to the church dignitary investigating the local outbreak of blasphemy, Apolek's art conveys to the sinful, ignorant masses the sort of truth Jesus told, which was as unpalatable to the authorities then as now. And is there not more truth, he asks, in Apolek's paintings, which ennoble the spectator, who is also depicted as participating in them, than in the angry and condescending words of the clergy? Italian prelates and Polish priests, it would seem, are not at all out of place in nativity scenes set in the Renaissance, painted in the 1890s, and viewed by the narrator in 1920, when the Roman Catholic Church was being sacked by Slav hordes.

\section{Playing with History}

The historical parallels in Babel's stories are not without ironic paradoxes, but these in no way detract from the author's more serious intent. A good illustration of the structural function of historical myth is the narrator's apostrophe in "Church in Novograd": 
Нищие орды катятся на твои древние города, о Польша, песнь об единении всех холопов гремит над ними, и горе тебе, Речь Посполитая, горе тебе, князь Радзивилд, и тебе, князь Сапега, вставшие на час! (Детство, 104)

Hordes of beggars will converge on your ancient towns, O Poland! The song of a united proletariat is thundering above them, and woe unto you, Rzeczpospolita połska, woe unto you, Prince Radziwiłł, and you, Prince Sapieha, who have risen to rule but for an hour! (Complete Works, 206; translation revised)

Prince Janusz Radziwiłł (1880-1939/40), head of the Polish Conservatives, and Prince Eustachy Sapieha (1881-1963), Polish Foreign Minister, are continuing, as it were, their ancestors' ancient conflict with Muscovy as part of Pilsudski's plan to resurrect the Poland of the eighteenth century (Lew Sapieha, 1557-1633, planned to include Muscovy in the Polish-Lithuanian Commonwealth, and Janusz Radziwiłł, 1612-1655, sent punitive expeditions against Khmel'nitsky, the legendary forebear of Budenny). Yet in the draft manuscript, this is followed by a passage in which Babel' explicitly shows the Jews caught between the warring sides and comments that Budenny is seen by them as the contemporary Khmel'nitsky, notoriously responsible for the massacre of a number of Jewish communities in 1648, who fought the Poles. The conclusion is that history is repeating itself. ${ }^{7}$

Babel"s perceptive and often inventive use of myth calls up the historical background without need for an ideologically risky elaboration, as in "Crossing the Zbrucz," where the Red soldiers march along the "ever-memorable highway from Brest to Warsaw built on the bones of peasants by Nicholas I" ("по неувядаемому шоссе, идущему от Бреста до Варшавы и построенному на мужичьих костях Николаем Первым" [Детство, 101]). Novograd-Volynsk, taken by Soviet troops in this story, is situated on the Słucz, not the Zbrucz, a hundred miles to the south-west, and fell on 27 June 1920, at which time the rearguard could not have been strung out along the Brest-Warsaw road. What Babel' wishes to convey, however, in the succinctness of his fiction is the symbolism, historical and artistical of the crossing of the Zbrucz, which signaled the reversal of the Polish invasion of the Ukraine, as well as stressing the personal significance 
of the narrator's entry into Poland, with its East European Jewish population and Western heritage, and into the world of the First Horse Army.

The army of Cossacks and peasants, treading the path of destiny of Tsarist serfs along the road built by them, form part of the Bolshevik advance through Brest in the direction of Warsaw - the goal on the way to international revolution, which was, of course, never reached. To speak of building a road on peasants' bones is to visualize a historical memory of serfdom, specifically Peter the Great's building of St. Petersburg, but also to allude to Nikolai Nekrasov's poem "The Railroad" ("Железная дорога", 1864), which laments the suffering of the peasants who built the Moscow-St. Petersburg line at the behest of Nicholas I. These Russian cultural references prepare ironically for the symbolic crossing of a Styx by blaspheming peasants and Cossacks who are supposedly liberating the world. At the same time, this is a travesty of the Exodus story, a parting of a Red Sea that marks the passage from the promised land of socialism into the land of bondage. ${ }^{8}$ The crossing of the river suggests a road on the way to a red Calvary under apocalyptic portents in the blood-red sky. A drowning soldier defames the Virgin Mary. The fording of the river takes place amid nocturnal chaos and death.

Поля пурпурного мака цветут вокруг нас, полуденный ветер играет в желтеющей ржи, девственная гречиха встает на горизонте, как стена дальнего монастыря. ... Оранжевое солнце катится по небу, как отрубленная голова, нежный свет загорается в ущельях туч, штандарты заката веют над нашими головами. Запах вчерашней крови и убитых лошадей каплет в вечернюю прохладу. Почерневший Збруч шумит и закручивает пенистые узды своих порогов. Мосты разрушены, и мы переезжаем реку вброд. Величавая луна лежит на волнах. Дошади по спину уходят в воду, звучные потоки сочатся между сотнями дошадиных ног. Кто-то тонет и звонко порочит богородицу. Река усеяна черными квадратами телег, она полна гула, свиста и песен, гремящих поверх лунных змей и сияющих ям. (Детство, 101)

Fields of purple poppies flower around us, the noonday wind is playing in the yellowing rye, the virginal buckwheat rises on the horizon like the wall of a distant monastery. ... An orange sun is 
rolling across the sky like a severed head, a gentle radiance glows in the ravines of the thunderclouds and the standards of the sunset float above our heads. The odour of yesterday's blood and of slain horses drips into the evening coolness. The Zbrucz, now turned black, roars and pulls tight the foamy knots of the rapids. The bridges have been destroyed, and we ford the river on horseback. A majestic moon lies on the waves. The horses sink into the water up to their backs, the sonorous currents ooze between hundreds of horses' legs. Someone sinks, and resonantly defames the Mother of God. The river is littered with the black rectangles of carts, it is filled with a rumbling, whistling and singing that clamour above the serpents of ther moon and the shining chasms. (Red Cavalry and Other Stories, 91)

If the first half of the story is permeated by violation of nature (emphasized by the monastic and virginal image of the buckwheat) and death in nature, then the second part introduces unborn life embodied in the Jewish mother-to-be and future deliverance out of death and destruction. "Crossing the Zbrucz" opens with a military report of the taking of Novograd-Volynsk. But the Soviet acronymic jargon of war gives way to a poetic style whose lyrical resonances jars with the violence of a ritual passage into the world of Red Cavalry, a modernist juxtaposition that recalls a variety of texts from The Lay of Igor to nineteenth-century romanticism and symbolist poetry. ${ }^{9}$ But Babel's use of the epic, while drawing attention to the historical significance of the conflict between Russia and Poland, Bolshevism and Capitalism, the Slavs and the West, is highly ironical, and the bloody "standards of sunset" are premonitions of death, introducing a conflicting voice in the tale's polyphony. ${ }^{10}$ The resulting modernist web of cultural memory makes the past present, to paraphrase T. S. Eliot's contemporary essay, "Tradition and the Individual Talent," and it is subversive in its referencing of literary texts and historical events, which are filtered through a parody of epic, skaz and a juxtaposition of the lyrical and the grotesque. ${ }^{11}$

In fact, the story sets up an intertextual connection with a very different parallel in Russian history, the triumphant Russian victory over Napoleon, in K. N. Batiushkov's uncompleted "The Crossing of the Nieman by Russian Forces on January 1, 1813" ("Переход русских войск через Неман 1 января 1813 г.", published 1830). 
In this neoclassic description of the young tsar Alexander I and his elderly general, Kutuzov, surveying the troops at the beginning of the campaign to repulse Napoleon from the Russian empire, the sky is indeed dark and the light over the corpses somber, but the outcome is very different from the Russian repulsion of the Poles from the Ukraine and the invasion of Poland in Red Cavalry. The irony of Babel"s reversal of a poetic topos can be easily seen if we compare Batiushkov's "The Crossing of the Rhine" ("Переход через Рейн," published 1817), which celebrates the crossing into Western Europe of Russian troops, following the Roman legions, covered with glory and honor:

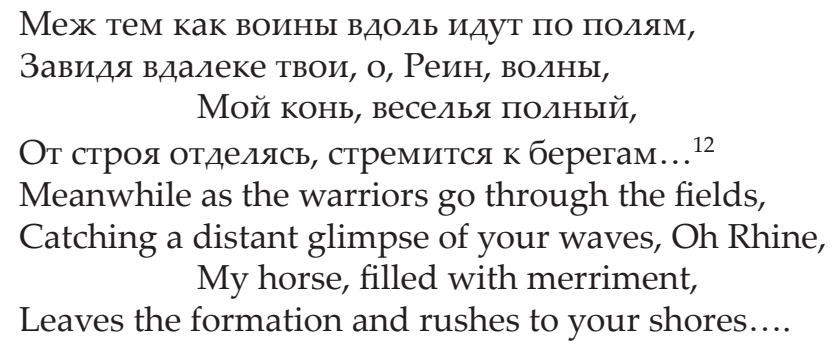

The closing scene of the shouts and curses falling silent and the heroic unison of a powerful army could not serve more of a contrast to the shouted obscenities and chaos of the crossing of the Zbrucz which is described as a violation of the virginal natural landscape. The "memorable" highway that Nicholas I used to check the abortive insurrection by Poles in 1830 is an ironic reminder of absolutist tyranny, for it is now being used to bring questionable liberation from Tsarist repression. ${ }^{13}$ Far from raising expectations of a great Russian victory, as Marc Schreurs has suggested, ${ }^{14}$ intertextual allusion subtly points to the failure of the Polish campaign and the international revolution.

\section{The Jewish Jesus}

By contrast with the semen-oozing seductive crucifixes of the established Church, described in "The Church in Novograd," the portrayal of the historical Jesus presents a rather un-messianic, earthly figure. 
Apolek's, or rather Babel's, Jesus is as aesthetically sensual and human as the virginal theology of the "winking madonnas" is ascetic and inhuman. Apolek's parable of Jesus and Deborah, in the Red Cavalry story "Pan Apolek," may have some basis in popular folklore or the rich Jewish tradition of stories denigrating the Christian messiah, such as the fourteenth-century The History of Jesus (תולדות ישו), in which Joseph sires Jesus when he disguises himself as Mary's bridegroom Yokhanan (John). Apolek not only demythicizes Jesus, but rewrites the Gospels, relating that the wedding night of the Israelite virgin Deborah ended in tears of shame when she took fright at her approaching bridegroom and vomited. Jesus takes pity on her by dressing in the clothes of her bridegroom, just as it is Jesus who sends the angel Alfred to Arina in an earlier story, "The Sin of Jesus" ("Иисусов грех", 1922). This is a hilarious tale of the drunken lust of a Russian peasant woman who crushes the angel Alfred in her inebriated sleep, then refuses to forgive Jesus for her life of incessant sex and pregnancy. It seems to derive from a tale in Boccacio's Decameron about a monk who disguises himself as the angel Gabriel in order to make visits to a Venetian merchant's wife, until he is discovered. The all-embracing love of Jesus in Apolek's parable is explicitly a union of the flesh. Lying in holy adultery with Deborah, Jesus proves his compassion more just than the law. Deborah is Hebrew for a bee, and Babel' clearly means this to refer to the "bee of sorrow" which stings Jesus:

Смертельная испарина выступила на его теле, и пчела скорби укусила его в сердце. (Детство, 120)

His body was drenched with mortal sweat, for the bee of sorrow had stung his heart. (Complete Works, 222)

Stricken by post-coital remorse, Jesus leaves unnoticed to join John in the desert.

The bee may represent here the deadliness of human passion, and also figures prominently in Afon'ka Bida's parable of the crucifixion in "The Road to Brody" ("Путь в Броды"). There the bee, by extension of the Christian virtue of industriousness essentially a proletarian creature, refuses to sting Jesus on the cross out of class solidarity, for Jesus came from a carpenter's family. 
The propensity for suffering and compassion, attributes of Jesus, are brought out in the syphilitic shepherd Sashka Koniaev in another Red Cavalry story, "Sashka the Christ" ("Сашка Христос"), whose meekness earns him the nickname "The Christ." It is by explicitly sexual compassion and an earthy acceptance of sin that Sashka, like Jesus in Apolek's parable, becomes himself something of a Jesus figure. His stepfather Tarakanych is a carpenter, like Mary's husband Joseph, but the play in his surname of "cockroach" on a slang term for fornication makes the allusion all the more amusing and profane. Sashka begs his stepfather to be allowed to become a shepherd, because "all the saints" were shepherds, but Tarakanych mocks the idea of a saint with syphilis. That night, Sashka has a vision from heaven in which he sees himself in a rosewood cradle hanging from the sky on two silver cords. A syphilitic Russian peasant, he too has aspirations to be supernaturally born. There is, however, an unstated irony in Sashka's exchange of his mother's sexual purity for permission to join the shepherds.

I will have more to say in chapter six about the Jew as Jesus in the context of the Civil War in Russia and the Ukraine, but let it be said that Babel"s use of biblical and mythical sources is, to say the least, unorthodox, and his mixture of Jewish and Christian sources is as irreverent as Chagall's nativity scenes; but then, as a non-believing Jew, he was not seriously interested in allegorical interpretations of the role of the Christian savior, such as in Blok's The Twelve, although the background of Marxist and religious messianism in prerevolutionary and revolutionary Russia is surely relevant. Babel's retelling of myth aimed to convey the contemporary mores of the Cossack and Russian masses. Matvei Pavlichenko in his saintly zhizneopisanie (biography - that is, his hagiography) in Red Cavalry differs from his patron saint in not being able to turn the other cheek (compare Matthew 5:38-39). His cheek burns with personal as well as revolutionary vengeance, and in retribution he tramples his former master to death.

Myth and mystification throw critics and scholars into confusion because Babel' disregards the niceties of geographical and historical accuracy, not to mention ideologically acceptable versions of history. Instead, the inventive fantasy of imagination vividly visualizes inner 
truths and historical parallels, in much the same way that the boynarrator of the Childhood story "In the Basement" transforms the dull, unpoetic details of a book about the life of Spinoza into a dramatic account of old Amsterdam, ending with a fantastic scene of the heretic's relentless, lonely death-struggle while Rubens (anachronistically!) stands by his bed taking a death mask. Just as the lies of the "untruthful little boy" expose hidden truths about his grandfather, so too Babel"s playful use of historical and religious myths poeticizes the narrator's view of actuality and thereby creates a novel interpretation of the contemporary meaning of legendary or supernatural events. In the transformation of myth several key devices of Babel's poetics are deployed, such as poetic parallelism or juxtaposition of the real and the ideal, the sacred and the profane, the divine and the earthly. The lurid rich colors which stream from Pan Apolek's palette are Babel's own, and in the author's taste for the heretical and the apocryphal may be sensed his belief in the potential of ordinary mortals for the epic and the spiritual. The Roman Catholic churches in Red Cavalry are as unredeemably doomed as the Jewish shtetl, yet despite the aesthetic revelations they offer, the disoriented Jewish intellectual does not feel for them the unbidden nostalgia and warm sympathy evoked by the Jewish areas he visits.

\section{A Red Elijah}

One Sabbath eve at the Zhitomir rebbe's, the narrator sees in the rebbe's son an unrecognized herald of the Messiah in a violent apocalypse. This Elijah (Il'ia) profanes the Sabbath by smoking, he has the "emaciated face of a nun" and the "forehead of Spinoza" that other Jewish heretic - and the Hasidim around him are likened to "fishermen and apostles." Like Liutov, Il'ia has tried to escape from the traditional Jewish home and ancestral past - he is described as a re-captured "runaway prisoner." Later, in "The Rebbe's Son" ("Сын рабби"), he renounces his mother (reminding us of Matthew 12:46-50) in the name of a new messianic ideology, the revolution. Il'ia dies, sexually impotent, and while the narrator, his ancient Jewish memory stirred, identifies with his spiritual brother, it is clear that the synthesis of Jewish values (Song of Songs, Maimo- 
nides, and phylacteries) with revolutionary ideals (communist leaflets, Lenin, and revolver cartridges) remains an impossible dream.

The Hasidim, for their part, seem oblivious to the destruction of their world, a building battered by history, in Gedali's phrase in "The Rebbe," which, he says, is eternal like the memory of a mother. Yet the desolation of war framed by the window provides mute comment on the timelessness of the Jews making Sabbath and sharpens the dichotomy between two worlds, two histories. There is, however, a more hidden key to Jewish cultural references. The rebbe belongs to the Chernobyl dynasty, which boasted members of the famed Twersky family, yet Babel' gives the rebbe the family name of Bratslavsky and names the rebbe's renegade son Elijah, who, in Jewish lore, will herald the messiah. The Jewish reader will immediately pick up the reference to the Bratslav Hasidim, also known as the "Dead Hasidim," so called because they had no rebbe since the death a century earlier of Nakhman of Bratslav. This was at the time the most messianic of Hasidic sects, and one of the best known Yiddish stories of Rabbi Nakhman is "The Rabbi's Son," about a thwarted messiah, widely available at the time in Martin Buber's German translation. ${ }^{15}$

There is evidence in Babel"s 1920 diary and in the drafts of the Red Cavalry stories that he wished to build the messianic theme into the framework of Red Cavalry and that he intended historical and religious myths to convey a topical message. In the draft entitled "The Death of Trunov" ("Смерть Трунова"), there is explicit mention of the coming days of the Messiah: "And I would have believed in the resurrection of Elijah, if it had not been for the airplane which was winging its way, etc." ("И я поверил бы в воскресенье Ильи, если бы не аэроплан, коротый заплывал и т.д." [Собрание сочинений, II, 352]). But in the story "Squadron Commander Trunov" ("Эскадронный Трунов"), the Elijah whose name is shouted by the quarreling Jews is Elijah the Vilna Gaon (1720-1797), the antagonist of the Hasidim: the Jews argue over old sectarian differences, in this case the rift between the "Orthodox" faction of Mekhezikei hadas (followers of the rebbe of Belz) and the proponents of accommodation with modernity (followers 
of the rebbe of Husiatyn), as if there were no war or revolution. Further evidence for the messianic theme is found in a projected story, "Demidowka" ("Демидовка"), which refers several times to Jeremiah, and was based on an incident in a shtetl on the Fast of the Ninth of Av, when Jews mourn the anniversary of the destruction of the Temple and read Jeremiah's lament over the fall of Jerusalem (Собрание сочинений, II, 335-41). As Babel' recorded in his diary, the Cossacks forced the local Jews to cook food for them on the eve of the fast, which happened to be a Sabbath when all work is prohibited. Everything was as in the days of the destruction of the Temple, Babel' wrote, and elsewhere he speaks of the "same old story," when time and again he has to witness the pillaging and torture of the long-suffering Jewish population at the hands of Poles and Cossacks. For example, the diary entry for 18 July 1920 specifies the point for point repetition of history in a description of the Jewish cemetery which has seen Khmel'nitsky (who was responsible for massacring many Jewish communities) and now Budenny (Собрание сочинений, II, 246), a parallel important for understanding the subtext of "Cemetery in Kozin" ("Кладбище в Козине").

As if to sharpen the historical analogy still further, the Cossacks marching into Beresteczko in Red Cavalry pass the watchtower of the hetman Bogdan Khmel'nitsky, where he was routed by the Poles in 1651. An old man crawls out of the Cossack burial mounds to sing of past glories. In the tradition of Khmel'nitsky, the first act of the Cossacks on entering the town is to murder a Jew. The irony is that the Cossacks marching past the memorials of their epic past are greeted by silence and shuttered windows. The Jewish quarter of Beresteczko "reeks in anticipation of a new era." The town's exmasters are a lunatic countess and her impotent son. A fragment of a letter in French, a fragment of the past dated 1820, one hundred years before the incursion of the Bolsheviks and the arrival of the narrator, recalls the Napoleonic Wars and Napoleon's death. As the narrator reads the letter, apparently from a mother to a husband long departed for war, which epitomizes the dying Polish nobility, a revolutionary council is being elected below the old Polish chateau. The historical parallel between the Napoleonic and revolutionary 
wars, between the Raciborskis' romantic past and their degenerate heirs, leads to an ironic story ending: power is supposedly being handed over to a bewildered petty bourgeoisie and to plundered Jews.

\section{Sunrise, Sunset}

Often, it must be said, Babel' needs myth for no more than a playful irony. In the scene of the Adoration of the Magi in the Odessa story "Liubka the Cossack," for example, three guests arrive from strange lands and present exotic gifts to David's mother-traditionally one of the wise gentiles is dark-skinned, although in this case he is a Malay, not an Ethiopian - and, as the three sailors dance, an orange star speeds across the sky, looking down on them (compare Matthew 2:9-12). These are not, however, gifts for a holy infant, but contraband Liubka is purchasing. If the baby apparently lacks an earthly father, then this only emphasizes Liubka's masculinity. She is, after all, a failed mother. The sleight of hand in weaning Davidka performed by Tsudechkis is, in a way, a "miracle," as perhaps implied by the Jewish dealer's name (reminiscent of the Polish word cud, miracle).

If the Odessa stories parody the language of the bible, midrash, and Yiddish idiom and celebrate the riotous and erotic exuberance of plentiful bounty and adventure, Babel"s play Sunset (3aкam, written 1926-1927) takes up the more sober note of Ecclesiastes introduced by Arye-Leib (in transliterated Hebrew) in "The End of the Almshouse," "Vanity of vanities, all is vanity." Sunrise, sunset is the way of the world. Mendel Krik, the carter, foolishly thought he could postpone the sunset of his terrible reign and cheat his sons Benia and Levka of their inheritance by selling his carter's business and running off to Bessarabia with the Gentile Marusia, who is pregnant by him. Benia is Bentsion, the "son of Zion." Benia's coup in the Krik household puts an end to the injustices of Mendel's reign of terror and reinstates the natural order of cyclical change-over from father to son, in effect applying the wisdom of Ecclesiastes that generation follows generation as the river flows into the sea.

Arye-Leib's allegory of King David's love for Batsheva in scene seven is instructive. Like David's sons, who seize the throne in their 
father's old age (compare 2 Samuel 11:1-26 and 1 Kings 1:1-40), Benia and Levka take over the carter's business and establish a new order, while in the bible it is David who restores order by ensuring the succession of Batsheva's son, Solomon. The repeated references to sunset and the coming of the Sabbath reinforce the idea that historical change is cyclical and no force can halt the setting of the sun. Mendel's desire to run off with a Russian woman and enjoy the rest of his life free from Jewish soup and Nekhama's whining is an attempt to stop the natural cycle of the succession of his sons. He wishes to prolong Friday and stall the setting of the sun that will inaugurate the Sabbath.

In the stage directions sunset coincides with the beating up of Mendel and later, in scene 8, Benia calls for the Sabbath to be a Sabbath:

Моя мысль такая: еврей не первой молодости, еврей, отходивший всю свою жизнь голый и босой и замазанный, как ссыльноселенец с острова Цахалина... И теперь, когда он, благодаря Бога, вошел в свои пожилые годы, надо сделать конец этой бессрочной каторге, надо сделать, чтобы суббота была субботой. (Собрание сочинений, I, 383)

This is my idea: a Jew no longer in the prime of life, a Jew who used to go about naked, barefoot, and filthy like a convict on Sakhalin Island! And now that, thank God, he is getting on in years, it is time to put an end to this life sentence of hard labor-it is time to make the Sabbath a Sabbath. (Complete Works, 792; revised translation)

In the play's concluding speech, the local rabbi Ben-Zechariah warns that Joshua the prophet (compare Joshua 10:12-15) and Jesus of Nazareth (a reference to Luke 23:44-55, omitted in all but the first edition of the play) were mistaken in thinking that they could alter the natural, divinely ordained course of events by symbolically stopping the sun:

День есть день, евреи, и вечер есть вечер. День затопляет нас потом трудов наших, но вечер держит наготове веера своей божественной прохлады. Иисус Навин, остановивший солнце, всего только сумасброд. Иисус из Назарета, укравший солнце, 
был злой безумец. И вот Мендель Крик, прихожанин нашей синагоги, оказался не умнее Иисуса Навина. Всю жизнь хотел он жариться на солнцепеке, всю жизнь хотел он стоять на том месте, где его застал полдень. Но Бог имеет городовых на каждой удице, и Мендель Крик имел сынов в своем доме. Городовые приходят и делают порядок. День есть день, и вечер есть вечер. Все в порядке, евреи. Выпьем рюмку водки! $!^{16}$

Day is day, Jews, and evening is evening. Day crushes us with the sweat of our labors, but evening holds in readiness the fan of its divine coolness. Joshua the Prophet, who stopped the sun, was a bit crazy. Jesus of Nazareth, who stole the sun, was an evil madman. And here is Mendel Krik, a member of our synagogue, who has turned out to be no cleverer than Joshua the Prophet. All his life he wanted to bask in the heat of the sun, all his life he wanted to stand where the midday sun stood. But God has policemen on every street and Mendel Krik had sons in his house. Policemen come and make order. Day is day, and evening is evening. Everything is in order, Jews. Let's drink a glass of vodka! (Complete Works 798-99; translation revised)

In the words of the local oracle, Rabbi Ben-Zechariah, everything is all right because day is day (a burlesque reference to Joshua 10:12-15), and Mendel's revolt against the natural order has been averted, though to say that Joshua was nothing more than a madman, and that Jesus was evil and crazy, is not so much heretical in the mouth of a rabbi (though Babel' may have been thinking of Midrash Kohelet 111:114), as inventively adapted to Babel's message in the play. It is also a justification for Benia's bloody coup, which might at first glance be read as a violent intervention like the Bolshevik revolution, but must be understood rather differently in the context of the Jewish literary tradition.

Sunset, which begins the weekly Jewish Sabbath, heralds the day of rest which is, in Jewish thought, a taste of messianic times and the world to come. In the Yiddish writer Y. L. Peretz's dramatic poem The Golden Chain (די גזאלדענע קייט, 1907-1913), the Hassidic Rabbi Shloime wants to hold on to the Sabbath as long as he can, but his son restores the mundane order of this world; nevertheless, the hope for final redemption lives on. But "it was evening, and it was morning" (in the first chapter of Genesis) and the fixed order of Creation resists the revolt of Korach. ${ }^{17}$ In placing Mendel alongside 
Joshua, who stopped the sun, and Jesus, in a radical and mischievous rereading of the bible, Babel' would be suggesting that historical change is inevitable - the play is set between the revolutions, in 1913-but also cyclical. This is a message emphasized in the allegory of King David, told by Arye-Leib, the shames (synagogue sexton), after the downfall of Mendel, under a blood-red sunset. Mendel and David both faced attempts by their sons to usurp power, both strayed from the strict path of morality, but here it is Mendel who wished to run away with Marusia and evade the succession of Benia, known as the King. As a parable of Mendel's story, AryeLeib tells of King David's rise to power, his wealth and fame, and of how he took Batsheva, the beautiful wife of Uriah the Hittite (in the bible Adoniyahu's rebellion is quashed, Solomon is declared heir and David dies in old age, warmed by Abishag). The sunset of the Jewish world would thus seem to be not so much a prelude to the messianic Sabbath - the utopian age of socialism - but to confirm that history is cyclical and Ecclesiastes was wise enough to know that there was nothing new under the sun.

Among several possible interpretations of Babel's play, the allegorical sunset of traditional Jewish society in Russia is one which fits the historical situation of 1913, when the play is set, but seen from the anachronistic view of 1928. Benia does not fulfill any mission as a savior, and while the sun literally salutes the zenith of his power in "How It Was Done in Odessa," his role as king of the gangsters is something of a comic parody. The midrashic saying that God has many policemen or emissaries (shlukhim) and Arye-Leib's lengthy quotation of the medieval commentator Rashi's allegorical commentary on Song of Songs, or his quotation from a well-known Hebrew poem by ibn Ezra, summon, not without considerable irony, a common cultural knowledge that is shared by a pre-revolutionary Jewish community, ${ }^{18}$ but that is out of place on a Russian Soviet stage in the late 1920s. The play's brief and controversial run at the Moscow Art Theater (MKhAT), in a heavily cut version, came at a time when Jewish themes and sources were being heard infrequently in Russian - soon they were to be suspect as "nationalistic."19 By the end of the 1920s, only a Marxist reading of history was acceptable, which is one reason why it is so remarkable that Sunset 
was actually staged in Stalinist Russia. The profanity of the Odessa carters, who interrupt a Sabbath eve service with vulgar gossip and talk of grain prices, and Benia's shameful treatment of his father nevertheless represent an intrinsic and vibrant ethnic Jewish world that has vanished forever.

\section{Journey to Cultural Memory}

To the end, Babel' remained preoccupied with Odessa and childhood memories. One story, which he was working on for many years and published in 1932, "The Journey" ("Дорога"), will afford us a final example of referentiality in the subtext which sets up historical parallels that inform the meaning of the story. This story, which is a reworking of "An Evening at the Empress's" ("Вечеp у императрицы", 1922), tells of the narrator's journey through war-torn Ukraine to Petrograd. From the standpoint of the date of publication, the story would seem to stake claims for the implied author's ideological allegiance, concluding as it does on a note of joy at joining the Bolsheviks and finding comradeship such as is found only in "our country".

Yet we are back in the icy uncertainties of winter 1917-1918. The story relates a vicious incident in which the narrator's ethnic identity puts him at risk more than the biting cold and hunger. Yehudah Weinberg, a teacher, and his newly wedded wife are traveling to Petersburg with documents signed by the Bolshevik Commissar for Education, Lunacharsky. The train stops in the middle of the night and a telegraphist, after checking the teacher's documents, shoots him in the face. A peasant then unbuttons the dead man's pants, cuts off his genitals and stuffs them in his wife's mouth:

- Брезговал трефным, - сказал телеграфист, - кушай кошерное (Детство, 91).

"You were too squeamish to eat tref," said the telegraphist, "So here's something kosher to eat." 
The deadpan narration does not conceal the immediate danger to the narrator, who, as a Jew, is about to become target practice, but is allowed to run away after his money is ripped out of his underwear. The peasant makes it clear he is not mistaken that he is a Jew and tells him in Yiddish to run for it.

Reaching frozen Petrograd almost at his last breath, the narrator thinks of Yehudah Halevi, the medieval Spanish Hebrew poet, who also dreamed of getting to the holy city in the Promised Land but, according to legend, was killed at the gates of Jerusalem by an Arab horseman (in all likelihood Halevi died in Alexandria, where he had fled in 1140). The narrator does get to the Bolshevik Promised Land and lands a job as a translator for the Cheka, where, incidentally, he meets Moisei Solomonovich Uritsky, chief of the Petrograd Cheka murdered by Social Revolutionaries in 1918. The association with Yehudah Halevi reminds readers versed in Hebrew poetry of the well-known Odes to Zion, in which the poet declared his heart was in the East while he stood in the farthest West. It was one of these odes that Halevi was reciting when he was killed, according to the version of the legend, half-remembered by Babel"s narrator, which Heinrich Heine immortalized in his Hebrew Melodies (Hebräische Melodien, 1851). In Heine's version the horseman kills the poet with a lance and the poet is transported to heaven, where he is greeted with the hymn that welcomes the Sabbath eve, the same hymn which moved Heine in an imaginary and skeptical return after the 1848 revolution to the Jewish past in Hebrew Melodies. This Romantic reworking of Hebrew poetical longings for the ancient Jewish homeland gets a further twist of irony in Babel"s referencing it in the context of the murder of Uritsky and his decision to join the Cheka, pledging solidarity to a communist promised land. The teacher murdered because he is a Jew is given Halevi's first name, and it is a historical irony that the descendant of the victims of two centuries of Tsarist anti-Semitism should don the Tsar's robes and smoke his cigars. The description of the majestic chambers of the Russian royal family, moreover, reads like a tragic history book of a doomed autocracy. The narrator concludes "The Journey" with an inauguration into Cheka service and a life of comradeship and loyalty, but Jewish readers will discern another history to be read here. 
Only in Babel's second play, Maria (Mapus, 1933, published 1935 but repressed while in rehearsal), is there any portrayal of a new, nascent social order, replete with marianic allusions. This is a play inspired by the Odessa-born Maria Denisova, a sculptress who did

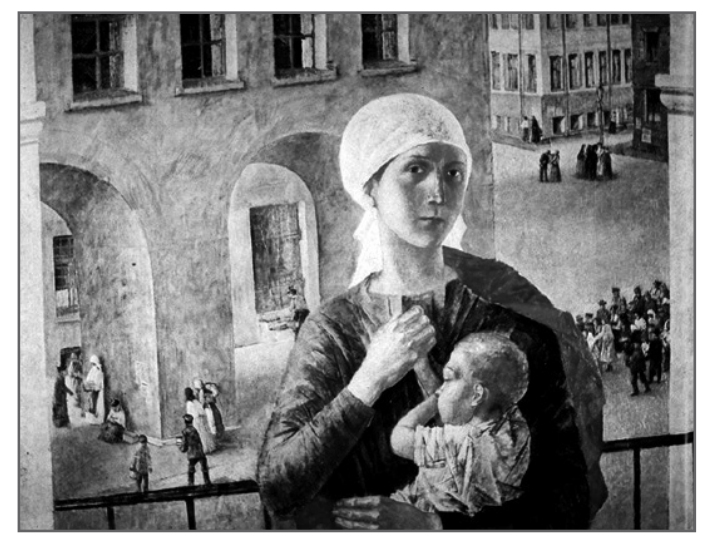

Kuzma Petrov-Vodkin, 1918 in Petrograd

(Tretiakov Gallery, Moscow)

agitprop work for Budenny's First Horse Army. It was apparently meant to form part of a trilogy called The Chekists (Чекucmol), which would presumably have spanned the Civil War years in the life of a former general's family, much like the one described struggling with the miserable conditions of revolutionary Petrograd in a sketch Babel' wrote in 1918, entitled "About a Georgian, a Kerensky Note, and a General's Daughter" (“О грузине, керенке и генеральской дочке: Нечто современное"). The final curtain falls in Maria on a scene somewhat reminiscent of Petrov-Vodkin's painting 1918 in Petrograd, in which a proletarian Madonna figure is portrayed against the background of the socialist city. In Babel's play, the worker Safonov's pregnant wife admires the apartment of General Mukovnin's family, which is now their home, while the enormous Nyusha, bathed in sunlight, cleans the windows. Elena is about to give birth in the new maternity hospital in a former palace, but she is not confident she will deliver a healthy child. The play ends on a mixed note of hope and uncertainty about the future. 


\section{A Literary Messiah}

In his programmatic essay of 1916, "Odessa," Babel' looks to the south of Russia, to sunny Odessa, as the only city which could give birth to the much needed Russian Maupassant.

...думается мне, что должно прийти, и скоро, плодотворное, животворящее вдияние русского юга, русской Одессы, может быть (qui sait?), единственного в России города, где может родиться так нужный нам, наш национальный Мопассан. (Собрание сочинений, I, 44)

Any day now, we will fully experience a fecund, revivifying influence of the Russian south, Russian Odessa-perhaps, qui sait, the only Russian town where there is a good chance our very own, sorely needed, homegrown Maupassant might be born. (Complete Works, 76).

This would be Russia's long-awaited literary messiah, who would banish the icy grip of Russia's St. Petersburg tradition (which Babel' thought evident in the later Gogol' and in Dostoevsky) ${ }^{1}$ and bring some sunshine to the provincial north, which dominated Russian prose fiction with its ethnographic sketches of everyday life. Even Gor'ky-soon to become Babel's patron and mentor-gets short shrift as a mere herald of the literary messiah who will come from sunny Odessa.

Чувствуют - надо освежить кровь. Становится душно. Иитературный Мессия, которого ждут столь додго и столь бесплодно, придет оттуда - из солнечных степей, обтекаемых морем. (Собрание сочинений I, 48) 
It is high time for new blood. We are being stifled. Literature's Messiah, so long awaited, will issue from there-from the sundrenched steppes washed by the sea. (Complete Works, 79)

Was Babel' thinking of himself as the Russian Maupassant born on Odessa's sunny shores? If so, this is a remarkable ambition for a twenty-four year old apprentice writer, eking out an existence in St. Petersburg as a student at a liberal arts college. Maupassant, though thought somewhat decadent at the time in Russia, was considered the last word in the art of the short story. Chekhov admired Maupassant's "world-wide fame and reputation" as a short-story writer, who could not be surpassed, while Tolstoy actually prefered Maupassant to Chekhov for his "joy of life". ${ }^{2}$

Babel' acquired a passion for French literature from his French teacher, a Breton by the name of Monsieur Vadon, and he got to know the French colony in Odessa, which, though not large, was influential, dating back to the first half of the nineteenth century. He began writing short stories in French at the age of fifteen. "I was writing them for two years," Babel' says, "but then I gave up. The peasants and the author's comments came out colorless; I was only good at the dialogue." ${ }^{3}$ This comment is revealing, because dialogue in Maupassant's Normandy tales is very important. Babel's did not inherit his love of France and Western culture from Russia's French-speaking aristocracy, but breathed it in with the cosmopolitan air of the Black Sea port, with its cafés chantants (described in "Notes from Odessa," 1918) and Italian opera (described in "Di Grasso," 1937). When the thirteen-year-old boy read Madame Bovary, Flaubert became his literary model; later it was to be Flaubert's pupil, Maupassant. Babel"s French translator relates:

Babel me dit qu'il a lu et relu Maupassant et Flaubert; qu'il ne connaît rien ou a peu près rien de nos auteurs contemporains. Je pense que cette formation première a de l'importance et que c'est un explication très utile ici. Au surplus, Babel, qui ne s'est jamais occupé de Proust, ni de Gide, ni de Paul Claudel, a suivi les chemins de l'esprit et de l'art français en remontant vers le passé. ${ }^{4}$ 
Babel told me he has read and reread Maupassant and Flaubert, and that he knows nothing, or almost nothing, of our contemporary authors. I think that this primal formation is significant and that it explains a lot here. On top of that, Babel, who has never been interested in Proust, in either Gide or Paul Claudel, has followed the paths of French art and the French spirit in going back to the past.

Maupassant was not then so popular in France, but was well known in Russia, where he had been introduced by Turgenev, almost simultaneously with the publication of A Life (Une vie) in 1883, as the best thing since Madame Bovary and free of the naturalism of Zola. ${ }^{5}$ In his preface to Maupassant's Complete Works, which appeared in Russian translation in 1908-11, Tolstoy praised his clarity of vision, but deplored his lack of moral judgment. Having himself embarked on a new spiritual path, and believing that the writer cannot divorce himself from moral questions, Tolstoy mistakes Maupassant's skillful detachment for uncertainty, while applauding his genuine talent for seeing through the hypocrisy of social convention. It is not difficult to understand why Tolstoy seeks moral sensitivity in the short stories of Maupassant and why they attracted Babel', who shares with Chekhov an authorial detachment combined with the deepest concern for the moral imperative of humanity. ${ }^{6}$ In his 1916 essay "Odessa," Babel' wrote,

А вот Мопассан, может быть, ничего не знает, а может быть все знает; громыхает по сожженной зноем дороге дилижанс, сидят в нем, в дилижансе, толстый и лукавый парень Полит и здоровая крестьянская топорная девка. Что они там делают и почему делают - это уж их дело. Небу жарко, земле жарко. С Полита и с девки дьет пот, а дилижанс громыхает по сожженной светлым зноем дороге. Вот и все. (Собрание сочинений I, 47)

Maybe Maupassant knows nothing, or maybe he knows everything. The carriage rumbles along the sun-baked road carrying the fat and crafty lad Polyte and a coarse, robust peasant girl. What they are doing and why they are doing it is their own business. The sky is hot and the earth is hot. Sweat pours from Polyte and from the peasant girl, while the carriage rumbles along the sun-baked road in the scorching heat. And that is all there is to it. 
This scene is taken from Maupassant's "The Confession" ("L'Aveu"), a story which Babel' translated into Russian for the three-volume collection of Maupassant's stories which he edited. ${ }^{7}$ "The Confession" figures in his own story "Guy de Maupassant" ("Гюи де Мопассан"), where it is both the intertext for the plot and the story which the narrator is translating with the seductive Raisa Benderskaia, the wife of an assimilated Petersburg Jewish magnate. "Guy de Maupassant" is set in Petersburg in 1916 and was written in the years 1920-1922, though only published ten years later.8 Maupassant, of course, was more concerned with the mother's calculating avarice than with the coachman's sexual exuberance, but then Babel' felt free to adopt and adapt as he wished. What he admires in Maupassant is the passion for, and the intimate knowledge of, life. Refusing to take a desk job, the narrator explains in "Guy de Maupassant".

Мудрость дедов сидела в моей голове: мы рождены для наслаждения трудом, дракой, любовью, мы рождены для этого и ни для чего другого. (Детство, 81)

The wisdom of my forefathers, was ingrained in me: we are born to delight in labor, fighting and love. This is what we have been born for, and for nothing else. (Complete Works, 680)

All-consuming curiosity and a passion for life, however, had their price. Babel' realized to exactly what tragic dilemma Maupassant's passion for life led, and, indeed, it was just this danger of the morbid obsession with sensuality as an ideal that Tolstoy had criticized.

The deeper he penetrated into life with this ideal, the more completely all veils were torn away, leaving bare the dark consequences and still darker realities. ... He begins to perceive the chasm between man and beast not in sexual passion alone, but in the whole fabric of life. ${ }^{9}$

Maupassant's tragedy, wrote Tolstoy, was that he perished because he could not free himself from his indulgence in life. Tolstoy pointed to the bitter irony that Maupassant could clearly see the repulsion of a view of life reduced to the pursuit of pleasure. 
Babel"s story "Guy de Maupassant" sets up a polemic between Tolstoy's and Maupassant's aesthetics, but in a way that is relevant more to the time of publication than to the time of the events in the story. The Swedish scholar Nils Åke Nilsson has emphasized the context of the story in the autobiographical theme of the writer's maturation and apprenticeship, as well as Babel's legendary silence, his noncompliance with demands to produce ideologically suitable material. ${ }^{10}$ Nilsson underscores the irony that, in an age of verbiage and long novels extolling Stalinism, Raisa pays the narrator-translator for his saving of literary capital, something that might put Babel"s Chekhovian economy in the same league as Maiakovsky's "Conversation with a Tax Inspector about Poetry" ("Разговор с фининспектором о поэзии").

Once Chekhov was caught rewriting stories by Turgenev and Tolstoy as an exercise in style. ${ }^{11}$ Babel"s translations and adaptations of Maupassant may be seen as a similar attempt at apprenticeship. This would explain Babel"s renewed love for Maupassant at a time when, after the publication of Red Cavalry, he was seeking a new simpler and sparser prose style. ${ }^{12}$ It is from Maupassant that Babel' has evidently learnt the secret of how language must grip the reader.

Фраза рождается на свет хорошей и дурной в одно и то же время. Тайна заключается в повороте, едва ощутимом. Рычаг должен лежать в руке и обогреваться. Повернуть его надо один раз, а не два. (Детство, 83)

A phrase is born into the world good and bad at the same time. The secret lies in a scarcely perceptible turn. The lever must rest in your hand and become warm. It can be turned only once, not twice.

This is how the narrator explains his art of translating Maupassant. The importance of finding the mot juste, of freeing language from clichés, is something that Maupassant learnt from Flaubert.

Quelle que soit la chose qu'on veut dire il n'y a qu'un mot pour l'exprimer, qu'un verbe pour l'animer et qu'un adjectif pour la qualifier. Il faut donc chercher, jusqu'à ce qu'on les ait découverts, ... et ne jamais se contenter de l'à peu près. ${ }^{13}$ 
Whatever may be the thing which one means, there is only one word to express it, one verb to bring it alive, and only one adjective to define it. So one has to search until one has discovered them, ... and never be content with something close.

The period that is placed at just the right moment can enter the human heart more lethally than any weapon (Детство, 83) - and it has certainly penetrated Raisa's heart. Babel"s own translations from Maupassant are characteristically fluid and occasionally inventive, emphasizing the atmosphere of sensuality and the interaction of setting with events, which Babel' was to learn to use with such laconic effect in his own stories.

Maupassant's "The Confession" provides the intertextual interreferentiality of Babel"s story, functioning in a similar manner to the way the boy introduces a reading of Turgenev's First Love in "Childhood. At Grandmother's" (discussed in chapter one). In "Guy de Maupassant" Babel"s narrator experiences Maupassant's art on two levels: the reading of Maupassant's stories and the translation of the stories into Russian by the narrator and Raisa. At both levels, the reading of Maupassant translates into his own experience of sensuality and into his theory of art. He discovers that Maupassant's fiction transcends an unappealing reality. This transcendence works like Spain does in the fantasy of his friend Kazantsev, but at some point he must return to the prosaic, sordid reality of grey St. Petersburg and discover the terrible price that the artist must pay for his insight into the extraordinary and interesting moments of human existence.

Translation, as L. Oukaderova has shown, ${ }^{14}$ works in the story as a homology in several ways. Parallel to the conversion of love into money in "The Confession," where Céleste shows her worth as a Normandy peasant and saves money by letting the coachman have his "fun," the starving narrator, like his Quixotic friend Kazantsev, is earning his keep by translating. Babel' himself apparently did the same in the hungry post-revolutionary years in Petrograd, whether for Lunacharsky's Comissariat of Education and for Gor'ky's literary projects or, possibly, for the nefarious Cheka. "Guy de Maupassant" sets up its own moral ambivalence when it plays intertextually 
with the erotic situations in the two stories, as well as playing metacritically with the aesthetic and economic value of translation from one culture to another, from one body to another. It might be added that translation was a common occupation for acculturated Jews, who functioned as mediators between Western Europe and Russia (Samuel Marshak is a contemporary example, Mandelstam another); here, the bohemian Jewish outsider enters the home of wealthy assimilated Jews to convert literary values into both erotic experience and money to pay his bills.

In his translation of Maupassant, the narrator gains a new insight into the theme and language of Maupassant's stories. He discovers the extraordinary moments of everyday life, as when the starving carpenter in Maupassant's "Idylle" sucks milk from a woman on the Nice-Marseilles express. Such moments brighten the humdrum world of mundane reality and expose extraordinary aspects of human nature which usually pass unnoticed. At the same time, Babel's narrator must learn the dangers of Maupassant's vision and confront the problematic relationship of life and art, in particular the tensions between passion and mortality. In that respect, the penniless, half-starved narrator of Babel"s story resembles the pseudo-autobiographical deictic self of the Childhood stories, who is in search of identity and the truth of life, but cannot help being the yarn-spinning boy of "Awakening," or the intellectual with spectacles on his nose and autumn in his heart in the Odessa stories.

Babel"s story opens with the contrast between, on the one hand, Kazantsev's imaginary world of Spanish castles and gardens, his bibliophilia that isolates him in his Quixotic dream world, ${ }^{15}$ and, on the other hand, the repulsion of the yellow, stinking, cold street in which he lives (Детство, 81). The contrast of the romantic fantasies of literature and imagination with the cold reality of Petrograd forms an axis on which the story's argument and plot revolve. Babel' is returning to the 1916 aesthetic thesis of "Odessa," as well as the more blatant polemic of "Line and Color," which opposes Kerensky's myopic impressionism to the bespectacled Trotsky's far-sighted line - a Party line, but also a historical vision devoid of romanticism. 
The thematic and structural opposition is developed further when the narrator comes to Bendersky's luxurious grandiose mansion on the corner of Nevsky Prospekt, overlooking the Moika, with its pink columns and the false pretentiousness of rich Jewish converts. The suggestion of debauchery and perverted sensuality in the eyes of the haughty maid is offset by the mock-antique Slavic wood carvings and the prehistoric scenes by Roerich, which speak for the decadent bourgeois identity purchased by the Benderskys. Bendersky himself is alleged to be close to Rasputin, and he is an ambiguous figure from whom reality is veiled, an example of living in illusions which the narrator does not appreciate until too late. Typically, Babel"s sense of the grotesque and the ludicrous succinctly sums up a social situation, as well as indicating something of the narrator's naivety, but Russian readers of Babel's story would have been aware that Rasputin met his grisly death just a few doors away, in Prince Yusupov's palace on the Moika during the night of 16-17 December 1916, the same month the action of the story takes place.

Passion here is the passion for life and the passion for art. It is no accident that the first translation by Raisa which the narrator must rework is Maupassant's "Miss Harriet," a tale of an artist's relationship with an English spinster that ends in death. ${ }^{16}$ However, the repeated motif of the debauched, haughty maid entering with a coffee tray offers an ironic counterpoint to the narrator's passion, while the glassy St. Petersburg sun, which lies on the worn and uneven carpet - the cold sun of Mandelstam's Petropolis - presents a disturbing contrast to the sun of France, the sun of passion that is the hero of the narrator's rendering of "The Confession" in Babel"s story "Guy de Maupassant" and in Babel"s programmatic "Odessa".

The glaring midday heat and exotic sensuality of the French sun infect the narrator's and Raisa's joint reading and translation of Maupassant's stories. Their relationship develops through the act of reading and translation, a reading and translation of desire, and reaches a climax as they act out the parts of Céleste and Polyte, but within the setting of Chekhov's "Mire" ("Тина"), where the Russian officer is trapped in the illusion and sensuality of the decadent, seductive world of an assimilated Jewess. In Babel"s story, the 
translation of carnal knowledge into erotic exuberance reveals a morbid truth. The narrator has squandered the material profits of his literary intimacy with Raisa, twenty-five rubles, in a bestial orgy of drunkenness that momentarily enlivens the hungry intellectuals' wretched garret. In his drunkenness, the narrator berates Tolstoy for taking fright at mortality and wrapping himself up in a handknitted religion. ${ }^{17}$ However, the next morning the narrator wakes up from his sexual fantasy about Katia to discover a depressing reality that underlies the dialectic between Maupassant and Tolstoy, although the bubble of the narrator's delusion does not yet burst. The drab grayness of the rundown, withered washerwoman should have alerted the narrator to his failure to recognize the truth about Raisa during their outing together on the Islands.

In Babel"s story, Raisa is wearing a ballroom dress. Her back is bare and she is drunk. There follows an initiation into the world of Maupassant, the world of women and wine, through a bottle of 1883 Muscatel. Three glasses lead him down a lane "where orange flames flickered and music played" (Complete Works, 684). Raisa's breasts move freely under her silk dress and her erect nipples intoxicate the narrator no less than the wine, while the clinking of glasses punctuates the narrator's paraphrase of "The Confession." His paraphrase argues for the force of the imagination to penetrate the essence of a situation with a few vivid details: the midday sun falling like rain, its drops forming the freckles on the cheeks of the brunette peasant girl, and its rays polishing the skin of the coachman with wine and cider (an invention of Babel"s). However, the original context of Céleste's confession to her mother is repressed, and the narrator's reading of the story becomes a confession of sexual desire to which Raisa responds, at the moment of Céleste's capitulation, by collapsing in hysterical laughter. "Raisa laughed out loud, slumping over the table. Ce diable de Polyte!" (Complete Works, 685). The scene of Céleste's intimacy with Polyte as the horse trots softly along, deaf to the coachman's call "Hue donc, Cocotte," is transformed into a celebration of sexual love, which has no place in the original matter-of-fact account of the commercial bargain between the two Normandy peasants. "The joyful sun of France embraced the buggy, shut off from the world by a faded brown cover. The young 
man and the girl-they needed no music" (Complete Works, 685). Babel"s narrator assumes the role of Polyte and kisses Raisa. "Aren't we going to have some fun today, ma belle?" ("а не позабавиться ди нам сегодня?"), echoing Polyte's proposal to Céleste. Raisa replies, "You're so funny" ("вы забавный"), a play on words not present in the original. ${ }^{18}$ Raisa appears as a seductive crucifix, an erotic, carnal Passion in keeping with the decadent taste of the furniture. "Of all the gods ever crucified, she was the most captivating" (Complete Works, 685).

However, above the head of the narrator/translator/Polyte looms the awesome fate of Guy de Maupassant in twenty-nine volumes. The artificial, lifeless sun of St. Petersburg touches "with thawing fingers" the spines of the volumes of Maupassant's works, a "splendid grave of the human heart," and they come crashing down on the intoxicated narrator.

Ночь подожила под гододную мою юность бутылку муската 83 года и двадцать девять книг, двадцать девять петард, начиненных жалостью, гением, страстью... Я вскочил, опрокинул стул, задел полку. Двадцать девять томов обрушилось на ковер, страницы их раздетелись, они стади боком... и белая кдяча моей судьбы пошиа шагом.

-Вы забавный, - прорычала Раиса. (Детство, 87-88).

Night obstructed my youth with a bottle of Muscatel '83 and twenty-nine petards crammed with pity, genius, and passion. I jumped up, knocking over the armchair and bumping into the shelf. Twenty-nine volumes came tumbling onto the carpet, falling onto their spines, their pages flying wild... and the white nag of my fate walked a slow walk.

"You're so funny," Raisa growled. (Complete Works, 685)

Now, the hints at a more somber interpretation of Maupassant's life and art are drawn together. The narrator walks home in the small hours of the morning to the cold garret on the other side of St. Petersburg. On the way, he indulges in a drunken fantasy, though he is quite sober, preferring to see the world as phantasmagoric and surreal. In the long, misty streets, he imagines monsters roaring behind steaming walls, the roadway amputates the legs 
of pedestrians. The veil of illusions in which he has been living as a writer and as a reader of Maupassant is about to rip apart. At home he finds the Quixotic dreamer Kazantsev asleep over Cervantes, and he takes up once more the life of Maupassant, this time told by Edouard de Maynial. The narrator considers the appetite he shares with Maupassant for joie de vivre, but reading of Maupassant's gruesome end in a lunatic asylum, reduced to bestial imbecility and blindness, he ponders the morbid consequences. This nascent awareness of insanity in drab surroundings recalls the madness of the Quixotic anarchist Sidorov in the Red Cavalry story "Italian Sunshine" ("Солнце Италии"), which similarly disturbs the narrator with foreboding. In Maupassant the passion for life battled with congenital syphilis and he wrote incessantly. His death at the age of forty-two, crawling on all fours, consuming his own excrement, ${ }^{19}$ is the ultimate antithesis in the dialectic of art and life. In the Chekhovian revelation that, so characteristically for Babel', closes the story, the St. Petersburg mist touches the narrator's window and suggests the foreboding of an essential truth. There could be no greater contrast to the mother's approval of her daughter's sexual barter, which, equally characteristically, closes "The Confession."

Babel"s story is a demonstration of Maupassant's technique of the short story, of Maupassant's masterly use of language, but at the same time, it offers a meditation on art and reality which is equally illustrative of Babel"s relationship to Tolstoy and Chekhov. The reading of a known literary text, which operates in the interreferentiality of Babel's story, moves the plot beyond that of the original, so that the story turns inward. It becomes a story about itself, about the process of literary creation, for the narrator is as much reading as he is writing. Like the narrator of Babel"s "My First Fee" ("Мой первый гонорар", 1922-1928), the narrator of "Guy de Maupassant" employs the acts of writing and reading to stimulate and simulate a passionate relationship with a woman "reader," who expresses her appreciation of the creative act by compassion for the narrator. In that regard, Vera is an ideal "reader," for she is moved to identify with the suffering of humanity and she comes to understand human nature, what people are capable of doing. Intimacy with Vera is the narrator's "first fee" and none have ever 
paid him as well. This "body-writing" is another kind of exchange of literary and sexual value which leads to a sexual initiation. ${ }^{20}$ Raisa, on the other hand, gains little understanding from the narrator's reading act, and it is the narrator himself who must reach an understanding of mortality and the consequences of passion.

Like Tolstoy, Babel' wishes to describe an entire world, but, as Babel' remarked in 1937, in a talk at the Soviet Writers'Union, whereas Lev Nikolayevich managed to detail everything that happened in the duration of twenty-four hours in his heroes' lives, he can only manage the most interesting five minutes-hence his preference for the short story as opposed to the epic realism of Tolstoy's novels (Собрание сочинений, III, 398). If Dostoevsky and Tolstoy represented two different modes of realism, Babel' clearly favored Tolstoyan clarity. ${ }^{21}$ Perhaps because he was an asthmatic short-story writer, it is not surprising he had time for only five minutes. This "five-minutes poetics" nevertheless penetrates essential truths, and brings Babel' within range of the realism of Maupassant and Chekhov. Indeed, lucidity of expression, the need to base oneself on experience and the understanding of the morality of the described milieu are the prerequisites laid down in Tolstoy's What is Art? (Что такое исскуство?). While Babel' admires Maupassant as master of the short story, he resembles Tolstoy in expressing his horror at Maupassant's apparent failure to reconcile art and reality in his own life. For all his abstinence from authorial commentary, there is a philosophy of life in the shortest of Babel"s stories. The cynical awareness of human avarice in the revelation that resolves the plot of Maupassant's "The Confession" is wholly different from the revelation which closes "Guy de Maupassant," but which, in a modernist epiphany worthy of Joyce, provides an insight into the narrator's own soul and pierces the truth of art. Despite his underlying pessimism that evil was rooted in the human condition, Chekhov believed in the latent dignity of mankind, which could only improve by being shown an image of itself. Maupassant, on the other hand, concealed beneath his clever pointe a mocking grin. ${ }^{22}$ As H. E. Bates, the English short story writer, put it, Maupassant and Chekhov differed not in what they wrote, but in what they were; Chekhov held the reader's intelligence in high regard and 
left unwritten implications to be understood, whereas Maupassant delighted in explicit details and colors. ${ }^{23}$

Babel' shows his understanding of these fundamental differences in his reception of both influences. It should not surprise us that one of the few faults Babel' found in Maupassant was precisely the lack of human warmth which is found in Chekhov. ${ }^{24}$ Nevertheless, at the close of "Guy de Maupassant," there is still a feeling of life's mysterious secret, of an important decision which must be made, however trivial or drab everyday life appears to be. This is quite different from the kind of melancholy resignation one finds in the inner revelation, say, in Chekhov's "The Literature Teacher" ("Учитель словесности"), or the despairing conclusion of his "The Fit" ("Припадок"), in which the student fails to communicate with the prostitute, unlike Babel"s Il'ia Isaakovich or the narrator of "My First Fee." ${ }^{25}$ Similarly, Riabovich, the spectacled misfit in a cavalry regiment in Chekhov's "The Kiss" ("Поцелуй"), who finds himself the unexpected recipient of a kiss, discovers the ordinariness of the experience and the mediocrity of life, again in marked contrast to the reaction of Babel's narrator to the same adventure in his story of the same name (published in 1937).

Riabovich, stooping and colorless, is at first lifted out of his inferiority complex by the unexpected adventure, and starts to fantasize about the erotic encounter with an unknown woman. However, in the end, he chooses not to return to von Rabbek's house with the rest of the battalion, as if to spite fate for his realization of the stupidity of it all, the pettiness of everyday life, and the insincerity of people who keep up appearances. In Babel"s story, the observation of the ordinary provincial family is mere background to rather more dramatic events. Billeted with an old paralyzed teacher and his family, the Tomlins, the narrator is told by his comrade, the Cossack Surovtsev, of the prospects of a catch, the old teacher's widowed daughter Elizaveta Alekseevna. However, whereas in Chekhov's story the soldiers' expectation of romance comes to nothing, the narrator strikes up a friendship with Elizaveta, to whom he introduces himself as a law graduate, an educated person. He then begins to draw the Tomlins out of the fear and despair instilled in them by Polish propaganda and spins a dream of future 
happiness in Bolshevik Moscow. This dream (unlike Riabovich's mediocre daydreams of marriage and a comfortable home) gives the Tomlins confidence in the unnamed narrator, but the couple's first kiss is interrupted by a telephone call from headquarters ordering an immediate withdrawal. Unlike Riabovich, the narrator does take the opportunity to return and reclaim the kiss, during the Soviet retreat from Poland in the wet, muddy autumn of the same year. They consummate their love in a potato storage shed, since the house has been taken over by the Soviet requisition commission, but Surovtsev wakes the narrator up at dawn and they gallop back to their squadron-none too soon, it turns out, as the paralyzed old teacher is dead. The freshness of the morning and the exhilaration of love are offset by the crossing of the old Polish border back into Russia. We do not need to be told that the end of the war spelt the end of both the affair with Elizaveta and the end of Bolshevik plans to make the revolution international. The Chekhovian subtext, from which self-knowledge and disillusion have been erased, is thus deeply ironic, both in its ideological opposition to the world of pre-revolutionary landowners and in its aesthetic celebration of a fleeting moment of passion.

\section{Two Suns}

The opposition between the St. Petersburg sun and the sun of France is central to "Guy de Maupassant," and it is quite clear that the glassy, cold sun of the Russian imperial capital (the eternal cold sun of Petropolis in the 1918 sketch "About Horses"), that reminds us of Mandelstam's dying sun of an apocalyptic Petropolis, is antipathetic compared with the vibrant, warm sun of France, the "hero" of Maupassant's story, which serves as an aesthetic equivalent to Babel"s idyllic Odessa sun in his 1916 manifesto. Could we see Babel', who was born the year after Maupassant's death, as a successor to the master of the short story, as no less than the Russian Maupassant and the long-awaited literary messiah? Babel' was already, in 1916, getting attention in the St. Petersburg press as an original talented author of short stories and sketches, and had not yet written his "Autobiography," which declared his entire debt to Gor'ky, as well 
as presenting ideologically clean credentials as a post-revolutionary writer. It is therefore interesting to see his amused reaction to being called a Soviet Maupassant in a friend's memoirs:

- Читади последнюю сенсацию? - И, не дожидаясь ответа, добавил: - Бабель - советский Мопассан! ... Это написал какой-то выживший из ума журналист.

- И что вы намерены делать?

- Разыскать его, надеть на него смирительную рубаху и отвезти в психиатрическую лечебницу...

- Может, этот журналист не так уже болен?..- заметил я осторожно.

- Бросьте! Бросьте ваши штучки! - ответил он, усмехаясь.Меня вы не разыграете! ${ }^{26}$

"Have you read the latest sensation?" And without waiting for an answer he added, "Babel' is the Soviet Maupassant! . . That is what some crazy journalist has written."

"And what do you intend to do about it?"

"Find him, put him in a strait-jacket and take him to a psychiatric clinic."

"Maybe that journalist is not so sick?" I remarked cautiously.

"Stop it! Stop your jokes!" he replied with a smile. "You will not pull my leg so easily!"

Babel's affinity with the French classics has been noted by many critics, especially in the mid-twenties when Western models were still acceptable, encouraged by Gor'ky, and promoted by the Serapion Brothers. ${ }^{27}$ In later years, identification with the French naturalists could provide grounds for ideological attack, and Babel' felt compelled to defend his non-Marxist view of Maupassant when asked to speak on his story "Guy de Maupassant" at the time of its publication in $1932 .^{28}$

Babel', who was well read in Western culture, was an individualist who owed allegiance to nobody. On correcting Paustovsky's prose, Babel' advised him not to borrow so much as a comma, and to trust solely his own sense of style, even if Paustovsky was influenced by Conrad, as Babel' was by Maupassant. ${ }^{29}$ Maupassant and Babel' nevertheless excelled in the same genre and the influence is unmistakable. ${ }^{30}$ For example, the one story in Babel"s series of 
sketches of the First World War, On the Field of Honor (Ha noxe честu, 1920), which was not adapted directly from Gaston Vidal's Figures and Anecdotes of the Great War (Figures et anecdotes de la Grande Guerre, 1918) and whose source has not so far been identified, ${ }^{31}$ bears a remarkable similarity to Maupassant's "Coco." Babel"s "The Quaker" ("Квакер") closes a cycle of four stories about the pointlessness of war, which undermine the illusion of honor and patriotism extolled by Vidal, very much Maupassant themes if one thinks of such stories as "Un coup d'état." Like "Coco," “The Quaker" deals with the malicious cruelty done to an innocent, defenseless horse. The horse's savior, the English Quaker Stone, is bound by the neo-Tolstoyan principles of his commandments and he carries the book of God under his arm, like the old Jewish philosopherstorekeeper in "Gedali"; his ideals are similarly doomed in a world that sends forth nought but shooting. The latter-day Don Quixote dies, stiff and upright, in his motorized steed for the sake of the horse he is trying to save. In "Coco," on the other hand, it is the horse, Coco, who dies unattended. The farm boy Isadore Duval, whom the villagers mockingly nickname "Coco-Zidore" and who is incensed at the injustice of having to feed an animal which is a financial burden, tortures the dumb creature in the same sadistic way as the groom, Baker, unleashes his resentment at Stone on the horse. The savage streak predominates in both Maupassant's peasants and in Babel's Cossacks, such as Konkin, who is of a similar age and mentality to Coco-Zidore. One might compare the vengeance in Babel"s "Prishchepa" and Maupassant's "Vendetta." Babel' matches the ironic satire of Maupassant in numerous examples of grotesque scenes of horror, even in the derivative $\mathrm{On}$ the Field of Honor, that remind us of the farcical gluttony of Walter Schnaffs or the bloody pulp of Javel's arm.

When Gor'ky read Babel"s play Mariia in 1933, the grand old man of Soviet literature concurred with critics who complained of Babel"s penchant for stark physiological details, and his "Baudelairean obsession with rotting human flesh." ${ }^{32}$ On the other hand, like Maupassant, Babel' also knew the deadly effectiveness of understatement and unadorned details. Once he read a phrase of Anatole France and changed his own description of a morgue 
because he realized it would have no effect. ${ }^{33}$ There are indeed bizarre as well as natural parallels between the brief creative lives of the two short story writers, in particular the confrontation of the artistic self faced with the moral repercussions of a view of the world, in the words of Babel"s "Story of a Horse," as a field of women and horses in May. To Babel' may be applied Maynial's estimation of Maupassant:

Raconter la vie de Maupassant c'est déjà faire l'histoire de son oeuvre. Peu d'écrivains, pourtant, ont eu plus que lui le souci de cacher leur existence aux curiosités indiscrètes, et la crainte de se laisser deviner à travers leurs livres. ${ }^{34}$

To relate the life of Maupassant is already to tell the story of his work. Few writers, however, have taken so much care as he has to hide their existence from indiscrete curiosity or have feared so much to reveal themselves through their books.

Yet despite the fastidious secrecy and divorce of writing and personal selves, equally relevant is the impossibility of escaping one's own identity, as Maupassant argues in the famous preface to Pierre et Jean. Maupassant dismisses the conventional attitude of art to objective reality and speaks not of le vrai but le vraisemblable. This mode of realism is striking in the most unexpected moments of everyday existence, the episodic, unique faits-divers that assume prophetic significance in the proper narrative setting. The curiosity about those intimate moments risks the integrity of the artistic self, and indeed Babel' shares an irresistible curiosity with Maupassant, whose sensual inquisitiveness was expressed in an almost pornographic love of the macabre..$^{35}$

While in Paris, in 1927-1928 and again in 1932, Babel' took an interest in the seamier side of Paris life, spending time and money at whorehouses and observing court cases. ${ }^{36}$ His stories "Rue Dante" and "The Trial" capture the atmosphere of Paris in the twenties with very few metaphors and little imagery. The narrator, who lodges in the Hotel Danton in Rue Dante, learns the French way of life, not by visiting the Louvre or by following the precepts of Marxist Leninism and studying the life of the proletariat, but by becoming a connoisseur of French food, wine, and women: he eavesdrops on 
a passionate affair which ends with the murder of his friend Bienal by the jealous Germaine, a glove-shop assistant. Although he is a chance bystander, the narrator feels a similar insight into passion and death to the revelation that ends "Guy de Maupassant." The story ends with the narrator sharing the view of the Paris streets below with Danton, who was guillotined in 1794 (one hundred years before Babel"s birth and the death of Maupassant) after a show trial. The visitor from Stalinist Russia may indeed ponder the gruesome proximity of erotic passion with death, but also that of revolution and corrupt power. The literary and historical allusions need little comment. While conjuring up a fairly accurate topography of contemporary Paris, Babel' takes the liberty of moving Danton's residence to a non-existent hotel, and the nearby Dante Street serves as a cultural marker (like Pushkin in "Karl-Yankel" and "Di Grasso"), which identifies the author with Western culture. Again, this juxtaposes the passion of life, the sun, which is the hero of Babel"s manifesto "Odessa," and its darker side, the grim consequences of the obsessive pursuit of love and happiness, on which the narrator of "Guy de Maupassant" also ponders at the end of that story. Dante and Danton are cultural referents, alliteratively suggestive of a larger, mythicized historical backdrop, that contrast the ideal of love in the Divine Comedy with the execution by guillotine of one of the most colorful and opportunistic leaders of the French Revolution. ${ }^{37}$ It is surely for this reason that the story ends with an aphorism not in French, but in Italian: God punishes those who do not know love (Dio castiga quelli, chi non conoscono l'amore). As Bienal's corpse is taken away, we may well wonder whether his claim that France's fame rests on the perfection of cuisine and love might not reveal unforeseen, more somber aspects of national character and history.

Whatever the extent of the purely literary influence, Babel' knew that the temperament of the Frenchman was closer to the heart of an Odessite than was Kipling. He told his fellow Odessite, Konstantin Paustovsky,

-У нас в Одессе... не будет своих Кипдингов. Мы мирные жизнелюбы. Но зато у нас будут свои Мопассаны. Потому что 
у нас много моря, солнца, красивых женщин и много пищи для размышлений. Мопассанов я вам гарантирую.

We in Odessa ... will not have our Kiplings. We are peaceful lovers of life. But we will have our Maupassants. Because we have a lot of sea, sun, beautiful women, and a lot of food for thought. I can guarantee you Maupassants. ${ }^{38}$

In the 1930s, Babel' was searching for a clearer, plainer style, but he proved inadaptable to middlebrow, mass-produced, Stalinist fiction. Both the influence of Maupassant and Babel"s aesthetic view of life were out of tune with the times. 


\section{Babel"s Civil War}

\section{Mapping the Semiotics of Red Cavalry}

Many readers and scholars have come away from reading the Red Cavalry stories (often in their censored form) confused about the author's moral and political position. Was Babel' a devout Communist who wrote ironically about his former ideological weaknesses in the war for socialism? Did he side with Liutov or Gedali? In this chapter I will argue that an analysis of semiotic mapping of ethnic identity in the Red Cavalry cycle can reveal much about the construction of ideological conflict. Moreover, if we compare other Civil War prose fiction in Russian, as well as stories of war and revolution in Yiddish and Hebrew, we will better understand the context of Babel"s portrayal of the alienated Jewish intellectual.

Yurii Lotman, in his pioneering study of the semiotics of the artistic text (including both the visual arts and literature), emphasizes the relation of ideological discourse to the structuring of plot and composition in the representation of the imagined world. The language of the text organizes the imaginary universe into a spatial model that reflects the points of view represented in the text, so that the value systems accruing to protagonists are structured in a binary opposition of near:far, enclosed:unenclosed, high:low, as well as, metaphysically, valued:valueless, good:bad, mortal:immortal, familiar:alien. ${ }^{1}$ Lotman takes his cue from the abstraction of space in physics and mathematics, but these binary oppositions are clearly derived from structural anthropology, and particularly from the work of Claude Lévi-Strauss, though Lotman also draws on the Russian Formalists Shklovsky, Tomashevsky, and Propp. The example of familiar:alien (свой:чужой)-literally, one's 
own:another's - is especially significant in the semiotics of spatial modeling, which conceptualizes identity in terms of religious, moral, and social value-systems and identity. Just as Gogol"s old-worldly landowners (in Evenings on a Farm near Dikan'ka) move in a circular space of protected domesticity, Taras Bul'ba is characterized as moving out of doors into the freedom of nature; danger comes from the inside, enclosed world and threatens the security of the world outside. ${ }^{2}$ Similarly, the conflicted world view of Liutov is organized into a binary opposition of self (своц̆) and other (чужой) between ethically and ethnically defined spatial models. The Cossacks belong to the outside world of nature, freedom, and violence, while the Jews are invariably associated with the indoor world of the intellect and culture, the dead past, passivity, and emasculation. In further developing the concept of the "semiosphere," Lotman emphasizes the universality of the boundary in cultural models, especially foundation texts, which marks space as alien or one's own in a binary opposition of up:down, top:bottom, inside:outside. It is a transitional space between conflict zones, but also acts as a filter that constructs the relation of center and periphery, self and Other, in cultural identity. ${ }^{3}$

From the beginning of the Red Cavalry cycle, the (as yet unnamed) Liutov identifies with his comrades, who are crossing a boundary, not just into the violent world of Red Cavalry, but into a conflict zone between nations and cultures. "Crossing the Zbrucz," as we saw in an earlier chapter, parodies a mythical rite de passage, but at the end it is one individual, the first-person narrator, who relates to the pogrom victims as alien, in hostile and stereotyped imagery; in fact, in a literary stereotype of Jewish death out of Taras Bu'lba or Turgenev's “The Jew” (“Жид”, 1846). ${ }^{4}$ Arriving in NovogradVolynsk late at night, Liutov fails to recognize the aftermath of a pogrom:

Я нахожу беременную женщину на отведенной мне квартире и двух рыжих евреев с тонкими шеями; третий спит, укрывшись с головой и приткнувшись к стене. Я нахожу развороченные шкафы в отведенной мне комнате, обрывки женских шуб на полу, человеческий кал и черепки сокровенной посуды, употребляющейся у евреев раз в году - на Пасху. 
- Уберите, - говорю я женщине. - Как вы грязно живете, хозяева... (Детство, 101-02)

I find a pregnant woman in my billeted apartment and two gingerhaired Jews with thin necks; a third Jew is sleeping close up to the wall with a blanket over his head. I find cupboards torn open in my billeted apartment, ripped up women's furs, human excrement, and fragments of the sacred crockery the Jews use once a year, on Passover.

"Clear this up," I say to the woman. "What a filthy way to live..."

These filthy Jews who jump around chimpanzee-fashion, "like Japs at a circus" (Детство, 102), are seen through an estranged viewpoint, as if by an anti-Semitic outsider who regards them as aliens who practice occult rites, though we soon discover that for Liutov, who has severed himself from his Jewish past, they are, whether he likes it or not, свой (his own). The poignant cry of the pregnant Jewess at the end of the story appeals for recognition of Jewish victimhood and for empathy with pogrom victims. That appeal is couched in human, rather than ethnic, terms, but the closure of the story belies Liutov's cruel indifference in turning his back on the Jewish past as inconsistent with a communist future. Whereas the story opens with a collective view, in the style of a military communiqué broken by the lyrical pathos of blood and violation, the ending mutes any response to the plea for compassion by the pregnant Jewess. Liutov's detachment from the collective shifts the weight of empathy to the victims he has misjudged. This initiating entry into Jewish space thus creates a dual perspective, which renders Liutov's point of view unreliable or ironic and introduces an ethnic perspective underlying the authorial viewpoint in the rest of the cycle, as the dialectic unfolds between the Jewish past, from which Liutov has severed himself, and the communist future, for which ignorant Cossacks and peasants are fighting, but which is also bringing about the final destruction of the shtetl. Liutov's vacillation is further complicated by his identification with western culture, which attracts him to the Polish space of Catholic churches (for example in "The Church in Novograd" and "At St. Valentine's Church"), but as a Jew from Orthodox Russia he recoils at the grotesque deception of the priests and charlatans. ${ }^{5}$ 
The verbal duel between Liutov and Gedali (in "Gedali") leaves the Jewish reader uneasy at the insensitivity to Gedali's suffering in pogroms and to his bewilderment at the injustice of the Bolsheviks' confiscation of his property. While Liutov parries the old man's Jewish suffering with dogmatic propaganda that the Revolution will open Gedali's eyes, it becomes apparent that it is Liutov who appears to be blind to Gedali's plea for universal justice in his ideal of a Fourth International of Good People. At the end, Liutov is moved by his nostalgia for the culture and traditions of his grandparents, and asks Gedali where he can find a taste of the Jewish Sabbath and the Jewish God-but it is too late, the shtetl has been destroyed, and Gedali goes to synagogue to pray, alone.

\section{Estrangement and Identity in "My First Goose"}

Liutov's conflicted self, torn between his roots in the dying Jewish past, on the one hand, and the outside world of the Cossack collective and the communist future, on the other, is presented in the spatial modeling of the text nowhere more clearly than in "My First Goose." This dilemma was typical of the young generation of Russianspeaking secular Jews in the early twentieth century, who, in the face of pogroms and discrimination, turned either to the growing Jewish national revival, or to one of the revolutionary movements. The simultaneous attraction to the sensuous non-Jewish world and moral repulsion from its murderous amorality and anti-Semitism are expressed in a binary opposition of familiar:alien (свой:чужой), associated with respectively open and closed spaces. As in the Childhood stories, the Jewish intellectual is pulled between, on the one hand, the open world of nature and sexuality and, on the other hand, the closed world of the Jewish past, ruined by pogroms, war, and revolution, from which he is forever breaking free but to which he is nostalgically drawn-a typical dilemma of the post-Haskalah Jewish intellectual.

In "My First Goose," the divisional commander Savitsky, whose powerful and sensuous body cuts across the hut, warns Liutov that guys with spectacles like him can expect to get their throats cut. Yet that murderous threat to his identity, as both an intellectual and 
a Jew, does not prevent Liutov being drawn to the towering body of the divisional commander Savitsky, which is strangely feminized, as if to reinforce the paradox of the erotic bond of the power relations between the violent Cossack and emasculated Jew: "He smelt of unobtainable scent and the sickly sweet coolness of soap. His long legs were like girls clad to the shoulders in shining jackboots" (Red Cavalry and Other Stories, 119; “От него пахло недосягаемыми духами и приторной прохладой мыла. Длинные ноги его были похожи на девушек, закованных до плеч в блестящие ботфорты" [Детство, 129]) . In Cossack space, Liutov perceives his self-image as an emasculated Jew, and he will have to overcome the humanistic scruples of a Jewish intellectual if he is to meet Savitsky's challenge and be accepted among the Cossacks. Savitsky's display of his masculine power (striking the table with a whip and issuing an order with threats to the commanding officer), as well as his obvious mockery of Liutov, makes clear that the test of acceptance will be sexual. Savitsky orders the quartermaster to find billeting for Liutov and to supply him with every pleasure, other than fullfrontal ("всякое удоводьствие, кроме переднего") - a pun on front-line rations (продовольствие). ${ }^{6}$

The dying sun and the yellow pumpkin of the road are not reassuring. The illiterate Cossacks greet Liutov by throwing out of their open courtyard his suitcase of manuscripts - the sign, along with his spectacles, of his alien identity. It is ironic that, after this impromptu symbolic expulsion from Cossack space, the narrator has Liutov emphasize his own degradation and admire the face of the young peasant lad making obscene gestures at him. Liutov's hunger and loneliness intensify the sense of his otherness. The smoke from the Cossacks' pot, in which they are cooking unkosher pork, is likened to smoke from a village home (“она дымилась, как дымится издалека родной дом в деревне" [Детство, 131]), thus spatializing the opposition between Liutov's rejected ethnic identity and the Cossack ethos to which he aspires.

However, his adherence to the communist future, referenced synecdochally by Lenin's address to the Second Comintern, is also in conflict with the value system of Cossack space. Liutov gives up reading Lenin's speech in Pravda and takes the quartermaster's 
earlier advice to "mess up a lady" if he wants to be accepted by the Cossacks. The violation is symbolic: he treads into dung the virgin white neck of a goose and sabers the landlady's sexual surrogate with "someone else's sword" ("чужую саблю"). The killing of the goose is a ritual initiation carried out in travesty of kosher slaughter, and in desecration of the Jewish ethical code. The landlady whom Liutov victimizes is half-blind herself, and wears the spectacles which identify the educated intellectual with the victim (an identification denied in "Crossing the Zbrucz," despite the fact that it is Liutov's brethren who are being slaughtered in pogroms across the Ukraine and the Polish borderlands); both Liutov and the Polish landlady belong to the closed, non-Cossack, indoor world. Only when he behaves like the Cossacks, killing, swearing, and hitting a woman's breasts, do they accept him into their ritual communion. They sit around their cooking pot like priests ("жрецы") and invite him to eat with them while the landlady's goose is (literally) being cooked.

Only then does the Cossack lad who first insulted the narrator so vulgarly allow him to regain his role of bespectacled intellectual and read to them Lenin's speech at the Second Comintern congress. This speech, which emphasized the role of the Third International in the world-wide struggle for communism (and the Soviet-Polish War was meant to be a first stage in exporting the Bolshevik Revolution), would have been read by workers and soldiers in any copies of Pravda which reached them. In this case, the Cossacks are only willing to accept the intellectual's role in mediating the words of Lenin after he has compromised his ethics; only an indoctrinated, dedicated Bolshevik reader would fail to sense the unacceptability of the act of moral and physical violation. ${ }^{7}$ The context of publication of the story in Maiakovsky's LEF, moreover, in an issue that carried articles extolling Lenin's language, indicates a travesty of correct ideological presentation of the role of Lenin, ${ }^{8}$ thus undermining Liutov's role as a puppet spokesman for the régime.

Typically, Babel' uses nature imagery to infer irony: the moon dangles like a cheap earring, the evening presses a maternal palm to Liutov's feverish head, while he exalts over the oxymoronic "mysterious curve" of Lenin's line of thought ("таинственную 
кривую ленинской прямой" [Детство, 132]). The Cossacks let Liutov sleep with them, their legs intertwined as they warm each other's' bodies. ${ }^{9}$ However, acceptance has come at a price. As the last line tells us, at heart he cannot accept the Cossack ways. The Cossack world remains morally and topographically Other (chuzhoi), and the story ends with the echo in the narrator's dreams of his crushing of the goose's neck: "I dreamed and there were women in my dreams, and only my heart, stained by murder, squealed and bled" ("Я видел сны и женщин во сне, и только сердце мое, обагренное убийством, скрипело и текло" [Детство, 132]). Despite the sexual and social communion of the Cossacks, the narrator cannot silence the moral Jewish voice within him, and even though he has gained communion in food and body with the Cossacks, his conscience squeals, in words that recall the sound of the goose's neck on which he trampled ("треснула и потекла"). His heart is not easy at the moral betrayal of the values of the Jewish indoor world - it bleeds with the bloodshed he has committed and squeals at his complicity with the larger rape and murder around him.
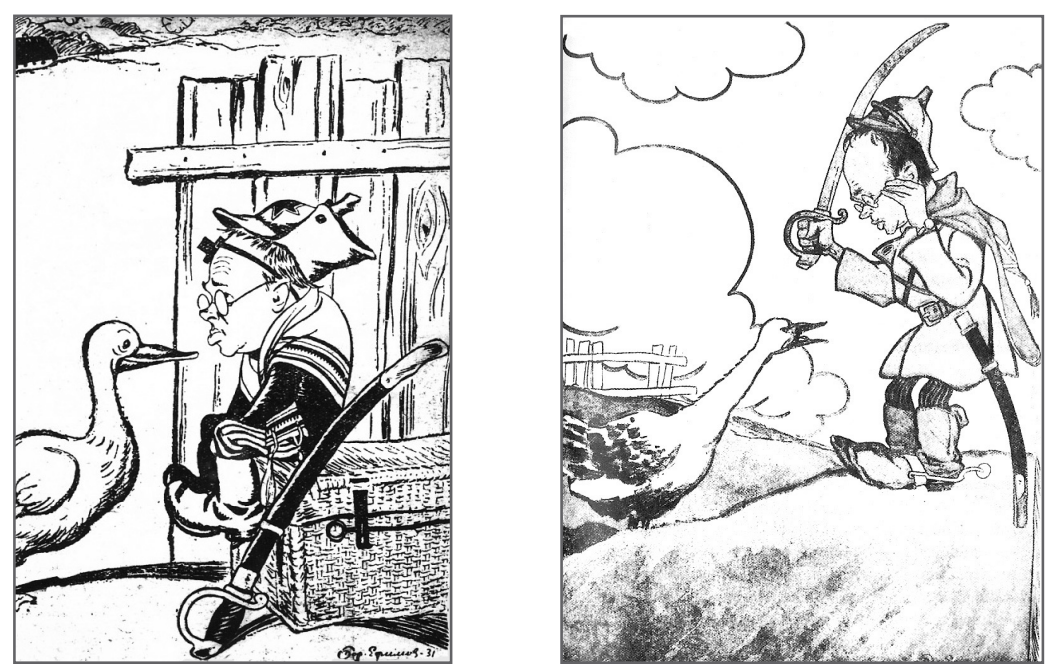

Two versions of Boris Efimov's caricature based on "My First Goose"; the "Jewish" reading (on the left) was never published (Russian State Archives of Literature and Art, Moscow) 


\section{Ethnic Identity and Ethical Dilemma}

In the following story, "The Rebbe," Liutov returns to the indoor Jewish world and meets his soul brother, his alter ego Il'ia Bratslavsky, who has tried to fuse Hebrew messianism with communist revolution. The description of the rebbe's room is thoroughly ambivalent, unlike the description of the Zhitomir rebbe in Babel"s diary, and reflects Liutov's post-Haskalah and post-revolutionary attitude towards his Jewish identity. Following Gedali's prophetic assessment of the eternal survival of the Hassidic movement and the Jewish people amid universal destruction, Liutov enters the rebbe's long, stone house, which he describes as cold and empty like a morgue. The scene which meets his eyes seems true to the characterization of Jewish space as lifeless, false, closed, and grotesque. Yet when the rebbe asks for Liutov to identify himself, he does so as a Jew from Odessa who has studied the Bible and is putting into verse Hershel Ostropoler stories. Outside the window lays the chaotic reality of the history which this Jewish space has denied and the hostile Cossack world which directly threatens it: "Outside the window, horses neighed and Cossacks shouted. The desert of war yawned outside the window" ("За окном ржали кони и вскрикивали казаки. Пустыня войны зевала за окном" [Детство, 135]). The rebbe blesses the Sabbath bread (obviously, in lieu of the unobtainable wine) and praises the God of Israel for choosing the Jewish people-the victims whose suffering in the reality outside of the window is all too evident. Nevertheless, the indoor Jewish space is imbued with the ambivalence of Christian associations: "Jews who looked like fishermen and apostles"; "with the emaciated face of a nun"; "refectory meal" ("евреи, похожие на рыбаков и на апостолов"; “с чахлым лицом монахини”; “за трапезу") which foreground the role of Il'ia as a latter-day Jesus or Spinoza, an apostate who has forsaken Judaism for the revolution (like many young Jews in this period), but displays the emaciated features of the emasculated Jew. The story ends with Liutov making a choice-leaving the dying Jewish space for the bright lights and technology of the agitprop train and his work for the propaganda newspaper Krasnyi kavalerist. The juxtaposition of the two spaces 
could not be sharper, but we cannot miss the detached irony with which Liutov's choice is narrated.

The next story, "The Road to Brody" ("Путь в Броды”), opens with Liutov mourning the loss of bees in Volhynia. But it could well be that behind this melancholic litany lies a real-life ethical dilemma. The day before Babel' noted in his diary his sorrow for the destruction of a beehive and for the more general destruction of war, he was witness to a massacre of Polish prisoners which he records in his diary for 30 August 1920. The prisoners are undressed in order that the Bolsheviks cannot pick out the officers, who were likely to be shot. One of them is a limping, terrified, bald Jew, probably an officer. The soldiers want to kill them all, but the squadron commander sees the opportunity for making off with some of the prisoners' clothes. A Putilov worker rages and threatens to kill all the bastards (Complete Works, 460; Собрание сочинений, II, 321). The account of that massacre forms the basis of a story never published in Babel"s lifetime, "And There Were Nine" ("Их было девять"), a title which appears in this diary account. In the story, the I-narrator is confronted by a Jewish prisoner who claims ethnic kinship with him and pleads to be saved.

Девяти пленных нет в живых. Я знаю это сердцем. [...] Всего вышло девять номеров. И четвертым из них был Адольф Шульмейстер, лодзинский приказчик, еврей. Он притирался все время к моему коню и гладия мой сапог трепещущими нежащими пальцами. Нога его была перебита прикладом. От нее тянулся тонкий след, как от раненой охромевшей собаки, и на щербатой, оранжевой лысине Шульмейстера закипал сияющий на солнце пот.

- Bы Jude, пане, - шептал он, судорожно лаская мое стремя. Вы - Jude, - визжал он, брызгая слюной и корчась от радости.

- Стать в ряды, Шульмейстер, - крикнул я еврею, и вдруг, охваченный смертоносной слабостью, я стал ползти с седла и сказал, задыхаясь: - Почем Вы знаете?

- Еврейский сладкий взгляд, - взвизгнул он, прыгая на одной ноге и волоча за собой собачий тонкий след. - Сладкий взгдяд Ваш, пане...

Я едва оторвался от предсмертной его суетдивости. Я опоминался медленно, как после контузии. (Собрание сочинений, II, 212-13) 
Nine prisoners of war are no longer alive. I know that in my heart. [...]All in all there were nine names. The fourth name was Adolf Shulmeister, a clerk from Lodz, a Jew. He kept snuggling up to my horse and caressing my boots with tender, trembling fingers. His leg had been shattered by a rifle butt and he left behind him a thin track, like a lame, wounded dog. The sun boiled the sparkling sweat on his orange, pockmarked, bald pate.

"You Jude, pane," he whispered, frantically caressing my stirrup. "You Jude!" he whimpered, dribbling spittle, writhing with joy.

"Get back into line, Shulmeister," I yelled at the Jew, and suddenly, seized by deathly numbness, slipped off my saddle.

"How come you know?" I asked him breathlessly.

"Your eyes, their sweet Jewish look," he yelped, hopping on one leg, leaving his thin dog's track behind him. "Your sweet Jewish look, pane!"

I barely managed to extricate myself from his condemned man's frenzy. I came back to my senses slowly, as after a concussion. (Complete Works, 357-58)

The ethical dilemma here divides the narrator's loyalties between his people and his comrades. The doomed prisoner appeals to him as a fellow Jew, who denies his identity but is clearly unable to resist the identification. On the other hand, his Jewish humanitarian ethical position is evident when the squadron commander Gorlov, a Russian from the Putilov steel works, sticks to his sense of proletarian justice and rejects the narrator's insistence on following Trotsky's orders that prisoners of war must be sent to headquarters for questioning. Clearly, such a direct depiction of divided loyalties could not be worked into Red Cavalry, where the dilemma is distanced in the complex figure of Liutov.

In "Squadron Commander Trunov," we can find a coded transformation of this dilemma. After Trunov is given a hero's funeral, Liutov relieves his grief by wandering around the town of Sokal' and generally behaves as an outsider. Seliverstov accuses him of doing an injustice to Trunov, yet Liutov can only comment that Trunov has no more judges in this world and he is his last judge ("нет больше судей в мире, и я ему последний судья из всех" [Детство, 190]). He then proceeds to relate the story of his quarrel with Trunov over Liutov's refusal to delete the shot prisoner from the list. As in "And There Were Nine," a Cossack soldier wants to make off with the 
prisoners' clothing, which arouses the commander's rage at such "betrayal." However, despite Trunov's steadfast decision to sacrifice himself to save the squadron from the American aeroplanes, not to mention Andrei Vosmiletov's solidarity in dying with him, Liutov sticks to his humanistic principles and the Cossacks ridicule him. But if we read this story as a rewriting of "And There were Nine" and compare the actual shooting of prisoners on which it is based, we can better understand the erasure of Liutov's own personal dilemma, making the clash of Jewish intellectual and Cossack values all the more stark and irreconcilable.

Liutov a fictional persona who embodies a figure of alienation rather different from the diarist on the Soviet-Polish front, should not be confused with the author, even if Babel' did pretend to be a Russian, and took the same pseudonym of Kirill Vasil'evich Liutov. Clearly, Babel' never wanted to be a Cossack, and his cover of a Russian identity did not fool local Jews, but then Liutov was an ironic composite portrayal of the Jew on horseback, who could not see how deluded was the ideal of welding communism and Jewish messianism, a delusion only too apparent in retrospect.

The binary opposition embedded in the imagery drives the dialectic throughout the Red Cavalry cycle. The values and characteristics of the Cossack skaz narrators are ideologically and ethnically hostile to those of closed areas with which they associate the intellectual in specs, the Jew who does not fight, the scribbling theoretician and administrator. By this logic, Balmashev in "Salt" thinks of the Bolshevik leader Lenin as a Jewish Communist and Trotsky, the commissar for war and a Jew, as the son of a Tambov governor who went over to the proletariat! This was, incidentally, a common confusion, as Trotsky commented on reading Babel"s story. ${ }^{10}$

The first edition of Red Cavalry (1926) ends with Liutov's identification with his alter ego, Il'ia Bratslavsky, who has triedand failed - to fuse Judaic values with communism, romance with killing.

Он умер, не доезжая Ровно. Он умер, последний принц, среди стихов, филактерий и портянок. Мы похоронили его на забытой станции. И я-едва вмещающий в древнем теле бури 
моего воображения,-я принял последний вздох моего брата. (Детство, 230)

He died before we got to Rovno. He died, the last prince, among poems, phylacteries, and foot-bindings. We buried him at a forgotten station. And I- who am barely able to accommodate the storms of my imagination within my ancient body - I received my brother's last breath. (Red Cavalry and Other Stories, 227)

The dialectic ends without resolution, and it is unclear whether Liutov will overcome his own weaknesses or whether the ideal is doomed from the beginning. Nevertheless, it is from this Jewish Communist that Liutov draws inspiration for the unruly imagination that rages within his "ancient" Jewish consciousness. However, in a later story, "Argamak," added to editions of Red Cavalry in 1933, the narrator does learn how to ride a horse with the Cossacks without drawing their enmity, but not before he has angered them for wanting to live without enemies.

In Babel"s stories, the narrator constantly seeks to escape the stifling confines of his native Jewish world, its ghetto mentality enforced by the territorial, economic, and social restrictions of the Tsarist Pale of Settlement. This theme of flight from the shtetl, from the traditional Jewish community, is a favorite theme of Jewish literature following the nineteenth-century secular Jewish enlightenment (Haskalah), but so often there is nowhere safe and secure to run to, despite the Zionist solution. The Novograd-Volynsk novelist M. Z. Feierberg indicated this dilemma (as I already noted) in the title of his novella, Whither? (לאן?, 1899). The Jew who has broken from his roots inside the Jewish home remains an outsider with no place in gentile society. Just as the child-heroes of Mendele, Sholom Aleichem, and Bialik are drawn to the realm of nature, to the gentile Marinka beyond the forbidden fence, in Babel"s Childhood story "Awakening," the boy yearns to flee beyond closed boundaries into the open space of the non-Jewish world, to abandon his violin for the lessons of nature:

В детстве, пригвожденный к Гемаре, я вел жизнь мудреца, выросши - стал лазать по деревьям (Детство, 71)

As a child nailed to the Gemara I led the life of a sage, when I grew up I started climbing trees. 
The boy is fighting the hydrophobia induced, according to him, along with bookishness and emotional hysteria, by the indoor urban Jewish life; he wants to swim, to break out of the traditional enclosed Jewish world into the unfamiliar non-Jewish world of nature outside. We have seen how this conflict is resolved with ironic ambiguity in "Karl-Yankel," and we will see an example of a Soviet Jew without Liutov's complexes in The Jewess. The choice made by so many Soviet Jewish intellectuals followed the path of acculturation begun before the October Revolution, ${ }^{11}$ a process completed with the disappearance of the traditional Jewish world after the Revolution and Civil War. The disassociation from Jewish group identity in the name of political solidarity and ideological acceptance was not always devoid of a nostalgic backward look, but the break was final.

\section{The Soviet Civil War Novel}

What characterized the Civil War novel most, in Soviet Russian literature of the 1920s, was the immediacy of the raw experience, conveyed through fragmentary episodes that reflected the chaos of lawless disorder and the difficulty of understanding what was happening, though from the retrospective standpoint of final Bolshevik victory. The legendary communist hero knew that power and might, and an appeal to peasants' and Cossacks' thirst for vengeance, were more likely to win battles than ideology. The class consciousness demanded by hard-line Marxist critics in portrayal of revolutionary heroes was not always in evidence in the fluid, but increasingly oppressive atmosphere of the mid-twenties (the Party declared its unwillingness to interfere in literary wrangles in 1925, leaving RAPP free to harass fellow travelers like Babel'). ${ }^{12}$

Red Cavalry appeared alongside other Civil War novels that also depicted conflicted intellectuals, ${ }^{13}$ and its graphic depiction of apparently senseless violence committed in the name of the Bolshevik Revolution was hardly unique, though Babel's irony tended to make it difficult to pinpoint his ideological position; the modernist detachment with which shocking scenes are delivered cannot be labeled "revolutionary romanticism." 14 However, when 
laid side by side with classics of Soviet prose fiction of the twenties, the artistic and ideological differences are clear. Voronsky, the eminent Soviet critic who published the work of Babel' and other fellow travelers in his journal Krasnaia nov', remarked upon reading the first Red Cavalry stories to appear in Moscow that he was struck by their departure from the experimental prose of Russian Civil War novels. Babel', he averred, captured the essence of a scene in all its realness with a Tolstoyan sense of vividness infused with deep understanding of the world, yet he gave it an epic quality that was very modern. ${ }^{15}$ Voronsky is probably correct that the kind of dialect speech and fragmentary impressionism we find in Vsevolod Ivanov's Armored Train 14-69 (Бронепоезд 14-69, 1922) ${ }^{16}$ would not have suited Babel's purposes. Ivanov's tale of earthy Siberian peasants fighting Kolchak and the Japanese insurgents was typical of the Zolaesque naturalism then in vogue, and which Voronsky thought Babel' avoided. But Ivanov's dispassionate recording of body parts spilling over neat pressed uniforms delivers the kind of shock which Babel' succeeds in achieving in his own detached narration, all the more effective because it comes within an intense lyricism:

Ночь детела ко мне на резвых дошадях. Вопль обозов оглашал вселенную. На земле, опоясанной визгом, потухади дороги. Звезды выползди из прохладного брюха ночи, и брошенные села воспламенялись над горизонтом. Взвалив на себя седло, я пошел по развороченной меже и у поворота остановился по своей нужде. Облегчившись, я застегнулся и почувствовал брызги на моей руке. Я зажег фонарик, обернулся и увидел на земле труп поляка, залитый моей мочой. Она вылилась у него изо рта, брызгала между зубов и стояла в пустых глазницах. Записная книжка и обрывки воззваний Пилсудского валялись рядом с трупом. В тетрадке поляка были записаны карманные расходы, порядок спектакдей в краковском драматическом театре и день рождения женщины по имени Мария-Дуиза. Воззванием Пилсудского, маршала и главнокомандующего, я стер вонючую жидкость с черепа неведомого моего брата и ушел, сгибаясь под тяжестью седла. (Детство, 198)

Night flew towards me on swift horses. The wail of the transports filled the universe. On the earth, girded round with screams, the 
roads were dying. The stars crept out of the night's cool belly, and abandoned villages flared up above the horizon. Carrying my saddle on my back, I walked across a havoc-torn boundary field and at the turning stopped to attend to a call of nature. Having relieved myself, I did up my flies and felt splashes on my hand. I switched on my flashlight, turned round and saw on the earth the corpse of a Pole, drenched in my urine. It was pouring out of his mouth and collecting in his empty eye-sockets. A notebook and fragments of the proclamations of Pilsudski lay beside the corpse. In the Pole's notebook there were notes of minor expenses, the order of the shows at the Krakow Theatre and the birthday of a woman named Maria-Louisa. With one of the proclamations of Pilsudski, marshal and commander-in-chief, I wiped the stinking liquid from the skull of my unknown brother and walked away, bent under the weight of the saddle. (Red Cavalry and Other Stories, 193)

The lyricism of nature descriptions here and in similar passages underscores the unseen danger looming out of the dark and the unbearable inhumanity of war, as seen by Liutov, who, distanced from his own near-encounters with death, must cope besides exhaustion and despair, with his complicity in what is done to his brother (a serious ideological error, of course).

In Fadeev's The Rout (Разгром, written 1925-26, published 1927) there is indeed a Jewish commander of a Red partisan company, Osip Abramovich Levinson, but he shares none of Liutov's inner struggles. In fact, his Jewishness is quite invisible, as was the case with many dedicated Jewish Communists. Levinson is the model communist leader, who passes on his life experience to his inferiors and suppresses his own weaknesses. Shrewd and cool-headed, he captivates the surly unruly ex-miner Morozka with the deep pools of his eyes, and while he does not let anything distract him from the task in hand and does not chase after women, he can nevertheless be warm and human in his relations with those under his command.

С той поры как Левинсон был выбран командиром, никто не мог себе представить его на другом месте: каждому казадось, что самой отличительной его чертой является именно то, что он командует их отрядом. Если бы Девинсон рассказал о том, как в детстве он помогад отцу торговать подержанной мебелью, 
как отец его всю жизнь хотел разбогатеть, но боялся мышей и скверно играл на скрипке, - каждый счел бы это едва ли уместной шуткой. Но Левинсон никогда не рассказывал таких вещей. Не потому, что был скрытен, а потому, что знал, что о нем думают именно как о человеке “особой породы” ... 17

From the day Levinson had been elected commander, nobody could imagine him in any other capacity; it seemed to everyone that the distinctive thing about him was the fact that he was in command. If he had told them how, in his childhood, he had helped his father to sell second-hand furniture, how his father had dreamed all his life of becoming rich, and was afraid of mice and played his fiddle rather badly, all of them would have thought it a bad joke. But Levinson never spoke of such things. Not that he was reticent, but because he knew that everybody regarded him as "a man of a special breed" ... 18

Even at the end, when only nineteen combatants survive the White Cossack ambush and Baklanov has been killed, Levinson masters his tears and knows that a man has to do his duty, that there is a life worth living and work to be done in the fields. It is Metchik who is the urban intellectual beset by doubts, invoking Morozka's resentment at the outset for being one of those educated "clean people" whom he does not understand or trust. Morozka, who saved Metchik's life when he was left behind wounded in a field, has only contempt for such types and suspects that Metchik is having an affair with his wife, the nurse Varya. Metchik, like Liutov, is not good at horsemanship, but this is because he neglects his horse. He is also similarly terrified of battle, but, in Metchik's case, this is due more to his inability to prove his manliness and become a fighter than to pricks of conscience about killing, or despair at the senseless violence of the revolution. It is also clear that, in comparison with Babel', Fadeev has more sympathy for the rough, undisciplined peasants and miners, bound by tribalism rather than politics, and shares their nostalgia for the simple and hardworking life of the village, evoking the colors and shades of the pastoral landscape, the shrill giggles of the women, and the busy harvest that goes on despite the war.

Even when he is unsure how to act, Levinson commands the men's fear and respect, yet he remains an outsider, and they do not 
feel the same about his ransacking of peasants' grain and produce as they do about Morozka's theft of melons. ${ }^{19}$ Levinson is actually pleased he did not see Morozka on his drunken rampage (there is no Prishchepa wreaking vengeance for his family in Fadeev's novel). However, it sometimes seems as if Liutov's quandary of the conflict between humane values and his wish to join the Cossacks, as in "My First Goose," is reflected in the polarity of Levinson and Metchik. Levinson has to overcome his own doubts and exhaustion, has to prove his ability to save a fighting force and feed his men, but the weak-willed, cowardly Metchik cannot come to terms with the killing of Frolov or the Korean farmer's pig; he remains revolted at the necessary cruelty of the revolutionary war and upset at his own inaptitude..$^{20}$ Levinson, by contrast with both Metchik and Liutov, was long ago won over to the right cause and left behind the skinny little Jewish boy he once was, no longer taken in by promises of spiritual salvation or provincial photographers' tricks of pretty little birds. ${ }^{21}$ Mathewson suggests that Levinson's solitude and physical deformity are bound up with his Jewishness: he is the lone leader, set apart from his men, who cannot imagine he has a private life and cannot see through his deceptive self-control to guess that he might be too distressed to know what to do. ${ }^{22}$ His authority rests on the exercise of his will, not ideological persuasion, but he maintains an uncompromising faith in a Leninist vision of a new kind of humanity that denigrated the old, weak-kneed humanism as an impediment to building the new world. In contrast to Liutov, Levinson's moments of weakness, not least his exhaustion and despair towards the final retreat at the end, emphasize the human dimension of the survival of the nineteen and the sacrifice that makes possible the formulaic closure of an uplifting perspective of the future. ${ }^{23}$ In Odessa-born Yurii Libedinsky's Commissars (Комиссары, 1926), Iosif Mindlov is a similar example of the Jewish Communist who sacrifices his feelings, despite his wife's death, for the cause and is not fazed by ideological confusion.

Of course, Babel"s primal sin was to allow the dialectic that runs through Red Cavalry to end without resolution, for Liutov's doubts about the justification of violence in the name of revolution when carried out by half-educated peasants and Cossacks are never 
answered. There is none of the conviction in the Bolshevik cause that is basic to the narration of Furmanov's Chapaev (Чanaeb, 1923), for all its careful noting of the anarchic freedom of the peasants, which had to be repressed, or the fact that some of the finest communist fighters were shot by Red Army men. The poor coordination between the grain producing areas and the starving industrial towns, the looting, rape, and the general lack of direction-all are duly noted in his diary by Klychkov the political commissar (an autobiographical stand-in for Furmanov himself), but these are always put in a more favorable perspective, aberrations that were corrected by the firm hand of the Party. Indeed, the misdemeanors of the Red Army are minor compared with the vicious atrocities of Kolchak's officers and their scorched earth policy. The local population usually greets their Red liberators joyously, especially the Jews of Ufa, who complain of their mistreatment at the hands of the Whites and vow to join the Bolsheviks if they have to retreat. There is never any doubt of the collective will to defeat the Whites, and the solidarity among Red volunteers, including Kirghiz Muslims, to save Soviet Russia remains always unquestionable. It is all a matter, quite simply, of political work among the masses; in fact, Furmanov's novel is unashamedly a record of the success of propaganda as a political weapon and a declaration of faith in its effectiveness in changing social behavior, as well as putting an end to "errors" and "shortcomings" in order to achieve complete political control over the anarchic forces unleashed by revolution. In Red Cavalry, none of the political commissars seem to have any impact on the illiterate peasants and Cossacks, and Liutov's work for the front-line newspaper on the agitprop train serves mainly as a foil to the Jewish past he is drawn back to in "The Rebbe."

Reading Red Cavalry side by side with Chapaev, one is struck by the absence of enthusiasm for the Bolshevik cause among the masses that is so prevalent in Furmanov's novel, illustrated by the letters from soldiers and peasants. Babel's skaz treatment of Cossack tales reads ironically, with a sense of history that does not always match the Party line. The ignorance of peasants and Cossacks was to be corrected by political commissars of the ilk of Klychkov through cunning and manipulation; it could not be the subject of irony, as in 
Red Cavalry, where the official discourse of the Party is appropriated for their own purposes by Pavlichenko or Balmashev and twisted to their mentality. ${ }^{24}$

Chapaev himself is introduced as a self-willed, adventurous Sten'ka Razin, or another Pugachev, a folk hero rising from the common people to fight exploitation and injustice, with a streak of unruly peasant anarchism and a reputation for a violent temper. His story is quite ordinary, like that of the Cossack commander Apanasenko, on whom Babel' modeled Pavlichenko in Red Cavalry, but it is presented as a sincere tale of protest and awakening political consciousness, ripe for Klychkov's indoctrination, even if he has only a general idea of the tenets of communism and mistrusts intellectuals, as well as having only scorn for the officers who give out orders at headquarters. The idealism of the early days of Bolshevik rule is evident in these local legends, and the victory goes to hardened commissars like Klychkov, who steel themselves to overcome their initial squeamishness and cowardice in order to harness the military skills and leadership of Chapaevs. Without the Chapaevs, the masses would not follow. The angry dismay Budenny felt on encountering himself depicted as much less than an epic hero, in the first Red Cavalry stories to appear in 1923-1924, is thus understandable. In the journal publication of "Commander of the Second Brigade" ("Комбриг 2"), for example, Budenny is described smoking with his eyes closed, ignoring the persistent reports of the advancing Polish cavalry (Детство, 374-75; Red Cavalry and Other Stories, 332-33); there could not be a stronger contrast with Furmanov's Chapaev.

The only revolutionary heroes not beset by doubt in Red Cavalry are the doomed idealists Il'ia Bratslavsky and Sidorov (the inveterate anarchist in "Italian Sunshine"), but also Liutov's colleague on the Krasnyi kavalerist, wall-eyed Galin in "Evening," who has no patience for the driveling, bespectacled Jewish intellectual. As Vasily woos Irina, Galin's unrequited love, he explains in endless detail the convolutions of history and the intricacies of Party doctrine, justifying the bloody violence of the revolution (a reference later removed). The story closes with a description of the Russian Galin curiously at odds with the opening mock-heroic glorification of 
the Party for driving the language of regulations through the bitter dough of Russian fiction and sending on the agitprop train dubious coworkers with the "faces of Ryazan Jesuses" (Детство, 174). Missing in later editions, this ending likens the Party worker Galin to Jesus on the cross: "His eyelid trembled over his wall-eye and blood dripped from the lacerated palms of his hands" ("Веко его билось над бельмом, и кровь текла из разодранных ладоней" [Детство, 177]). It seems that the distanced narrator, like Apolek, wishes to sacralize these grotesque figures, in an ironic inversion of history and myth (as we saw in a previous chapter), but the narrator gives no clue as to his own ideological position beyond deprecating his own weakness and despair. Instead, he is attracted to the mystique of Cossack leaders such as Kolesnikov, Savitsky, or Trunov, whose prowess he so much admires, but he sees through the motivation of the men who follow them. Already in his 1920 diary, Babel' was expressing serious doubts about the justification of violence, and he also saw clearly the gap between ideology and practice on the ground, between orders and the Cossacks' pilfering and savagery.

Что такое наш казак? Пласты: барахольство, удальство, профессионализм, революционность, звериная жестокость. Мы авангард, но чего? Население ждет избавителей, евреи свободы-приезжают кубанцы... (21.VII.20. Пелча - Боратин) (Собрание сочинений II, 252)

What kind of men are our Cossacks? Many-layered: rag-looting, bravado, professionalism, revolutionary ideals, savage cruelty. We are the vanguard, but of what? The population is waiting for liberators, the Jews for freedom-but who arrives? The Kuban Cossacks. (Complete Works, 403)

Описать ординарцев-наштадива и прочих - Черкашин, Тарасов,-барахольщики, лизоблюды, льстецы, обжоры, лентяи, наследие старого, знают господина. (Белев. 13.VII.20). (Собрание сочинений II, 237)

Describe the orderlies, the divisional chief of staff and the othersCherkashin, Tarasov-rag-looters, lickspittles, fawners, gluttons, loafers, products of the past, they know who their master is. (Complete Works, 390-91) 
Получен приказ из югзапфронта, когда будем идти в Галициюв первый раз сов[етские] войска переступают рубеж-обращаться с населением хорошо. Мы идем не в завоеванную страну, страна принадлежит галицийским рабочим и крестьянам и только им, мы идем им помогать установить сов[етскую] власть. Приказ важный и разумный, выполнят ли его барахольщики? Нет. Новоселки.-Мал[ые] Дорогостай. 18.VII.20). (Собрание сочинений II, 245)

We receive an order from the Southwestern front, when we cross into Galicia - it will be the first time that Soviet forces will cross the border-to treat the population well. We are not entering a conquered nation, the nation belongs to the workers and peasants of Galicia, and to them alone, we are only there to help them set up a Soviet power. The order is important and sensible-will the raglooters stick to it? No. (Complete Works, 398)

There is, as in "Squadron Commander Trunov," no judgment since Liutov himself is (in the eyes of the Cossacks) compromised for his failure to sacrifice himself as these revolutionary heroes, for all their flaws, have done. As we have seen, Liutov is forced to admit the ambiguity of his own moral position compared with the self-assurance and strong will of the Cossacks, against whom he measures himself. In this, Liutov is as captivated by the mystique of the Cossacks as Olenin is in Tolstoy's The Cossacks, but both Tolstoy and Babel' see beyond the myth of the Cossack ethos and know that it is not attainable. ${ }^{25}$ When Gor'ky defended Babel' from ideological criticism, he declared that Babel' had rendered the Cossacks beautiful from within, as Gogol' had done, he missed the Tolstoyan irony that Liutov can no more become a Cossack than Yankel in Taras Bul'ba. ${ }^{26}$

Liutov's performance of his moral weakness in "The Death of Dolgushov" ("Смерть Долгушова") likewise serves to dramatize, without authorial comment, Afon'ka's callous mercy killing of Dolgushov, whose innards are dripping in his death agony. Afon'ka is infuriated by Liutov's cowardice, which he takes as evidence of the bespectacled intellectual's lack of mercy for Cossacks like him. Liutov's concern, however, seems to be that he has lost Afon'ka's friendship 
- Афоня, - сказал я с жалкой улыбкой и подъехал к казаку, а я вот не смог.

-Уйди, - ответил он, бледнея,-убью. Жалеете вы, очкастые, нашего брата, как кошка мышку...

И взвел курок.

Я поехал шагом, не оборачиваясь, чувствуя спиной холод и смерть.

-Вона,-закричал сзади Грищук,-не дури!-и схватил Афоньку за руку.

-Холуйская кровь! - крикнул Афонька.-Он от моей руки не уйдет...

Грищук нагнал меня у поворота. Афоньки не было. Он уехал в другую сторону.

-Вот видишь, Грищук,-сказал я,-сегодня я потерял Афоньку, первого моего друга... (Детство, 144)

"Afonia," I said with a pathetic smile and rode over to the Cossack. "You see, I couldn't do it."

"Go away," he replied, turning pale, "or I'll kill you. You foureyed lot have as much pity for us as a cat has for a mouse."

And he cocked his trigger.

I rode off quickly, without turning round, my spine sensing coldness and death.

"Get out of here!" Grishchuk shouted from behind. "Stop playing the fool!" And he grabbed Afon'ka by the arm.

"That damned lackey," Afon'ka barked, "he's not going to get away from me..."

Grishchuk caught up with me at the turning. There was no sign of Afon'ka. He had ridden away in the other direction.

"You see, Grishchuk," I said, "Today I have lost Afon'ka, my best friend." (Red Cavalry and Other Stories, 115)

Liutov's identification with the Cossack warriors has been exposed as a delusion, and it is the bespectacled intellectual's fellow victim, Grishchuk, who stays Afon'ka's murderous hand and offers Liutov the peace offering of an apple, an act of charity which Liutiov accepts (though this acceptance was later erased from the story so that it did not end with any indication of reconciliation, regret, or reverence for the simplicity of Grishchuk's soul). Later in Red Cavalry, Liutov again plays the peace-loving weakling who, inexplicably, goes into battle with an unloaded gun in "After the Battle" ("После боя"). After he is assaulted by the epileptic Akinfiev (whom Liutov failed 
to prevent tormenting the prisoner Ivan in "The Two Ivans"), Liutov prays to be granted "the simplest of abilities - the ability to kill a man" (Red Cavalry and Other Stories, 222; "простейшее из умений-уменье убить человека" [Детство, 225]). Liutov's humanist principles are juxtaposed with the native justice and honor code of the Cossack fighter, and yet Liutov's position as a political commissar or war correspondent is always left ambiguous. Is he the bystander observing the horror of war or a complicit participant? The reader is left with no moral compass to orient the scenes of remorseless violence or shocking behavior (as in the treatment of the dead Shevelev's wife in "The Widow"). The weight of judgment is moved outside the narrative space of the story.

Unlike Alexander Serafimovich's Iron Flood (Железный поток, 1924), there is no impression in Red Cavalry of a stream of armed men forged into a fighting force by the iron will of a charismatic leader. A hard-line Marxist, Serefimovich was one of the leading Proletarian writers and himself descended from Don Cossacks. Serafimovich's raw prose captured the primal, savage outburst of popular wrath and despair in a Cossack village that goes over to the Bolsheviks and is trapped by the advancing Whites. In Red Cavalry, the Cossacks may be professional fighters, but their pillage of the local population cannot be contained, and no iron-jawed leader captivates the masses into obedience or channels their vengeful hatred for the enemy as in Chapaev and The Iron Flood.

For the simple masses, as for the intellectuals who supported the ancien régime, the revolution had unleashed mysterious and unknowable forces that turned their lives upside down and made the world suddenly menacing and unfamiliar. Mikhail Bulgakov's The White Guard (Белая гвардия, written 1923-1924; first published in serial form 1926) evokes the dream-like reality of Kiev in 19181919, when it passed from the German-sponsored rule by Hetman Skoropadsky, and when, amid rumors and uncertainty, terror and death stalked the streets. As in a dream, fragmentary, unconnected episodes piece together the story of the Turbins, a Russian family of loyalists caught up in seemingly random events that make their beliefs and values hollow and empty. The haunting dream sequences play out the protagonists' worst fears and fantasies. 
In Red Cavalry, too, the events seem uncontrollable, though more due to incompetence and disorder than to strange disappearances and inexplicable happenings. Liutov similarly encounters death as an absurd accidental interruption of normal life as he wanders through fields strewn with corpses, fleeing death in "The Road to Brody." In The White Guard, the murder of Yakov Feldman, the Jewish businessman, by Petliura's advanced guard entering $\mathrm{Kiev}^{27}$ is as sudden and shocking as the slaughter of the old Jew in Babel"s "Beresteczko," and the authorial distance makes it look no less unjustified. As pawns in a battle that takes no account of them, individuals suddenly find their previous lives irrelevant and meaningless. Defamilarization mirrors the incomprehension that all this is happening to them and can kill them. Nikolka, looking up at the swaying dentist's sign and hearing the windowpane smash, does not associate this with the lethal danger he is in, and does not fully understand he is the one being shot at. ${ }^{28}$ Similarly, fleeing Kiev in 1918, the narrator of "The Journey" is curiously detached from his own position as a Jew when anti-Semitic partisans board the train, cut off the teacher Yehuda Weinberg's penis and stuff it in his wife's mouth. The narrator is left to flee barefoot after being mugged in the freezing snow.

The modernist prose of Red Cavalry reflects the inexplicably aesthetic power of a violent world - the effervescent moment that Joseph Conrad spoke of in the preface to Nigger of the Narcissusand the juxtapositions of images resemble the modernist montage techniques of Soviet cinema of the period (Eisenstein once said that he found all he needed as a movie director in Babel"s stories). ${ }^{29}$ In a mock-epic description of the invasion of Poland, the orange sun in "Crossing the Zbrucz" reflects the bloody deeds of mortals, just as the sun suddenly bursting through the clouds at Petliura's inauguration in The White Guard is likened to pure blood.

От шара, с трудом сияющего сквозь завесу облаков, мерно и далеко протянулись полосы запекшейся крови и сукровицы. Солнце окрасило в кровь главный купол Софии, а на площадь от него легла странная тень, так что стал в этой тени Богдан фиолетовым, а толпа мятущегося народа еще чернее, еще гуще, еще смятеннее. ${ }^{30}$ 
Streaks of clotted blood and plasma flowed steadily from that distant globe as it struggled to shine through the screen of clouds. The sun reddened the dome of St. Sophia with blood, casting an orange shadow from it on to the square so that in that shadow, Bogdan turned violet, and made the seething crowd of people look even blacker, even denser, even more confused" ${ }^{\prime 31}$

However, in a weird parody of Pushkin's Bronze Horseman, the statue of Khmel'nitsky shakes off Petliura's men and furiously gallops off into the distance. Similarly, in Red Cavalry, Babel' has an ironic insight into the coalescing wheels of history as Budenny follows in the wake of Khmel'nitsky. The modernist prose speaks for the indifference and relentless cruelty of a world where human life is cheap. Lyricism only reinforces the shocking effect and brings an erotic charge (as we saw in the description of the virgin fields in "Crossing the Zbrucz").

The death of the Civil War hero of Eduard Bagritsky's The Lay of Opanas (Дyмa nро Onaraca, 1926), Iosif Kogan, at the hands of Makhno's partisans is a martyrdom envied by the Red soldier at the end of the elegy, and it serves as an example of unswerving loyalty and dedication with no trace of the irony and ambiguity of the death of the failed Jewish revolutionary Il'ia Bratslavski, which closes the first edition of Babel"s Red Cavalry, published the same year. Kogan is one of several token Jews among the countless Civil War heroes in Soviet literature of the 1920s. This token Jewish presence is perceived as "positive" because all traces of Jewishness have been washed out from it. If the recent pogrom experience is mentioned, as it is in Nikolai Ostrovsky's Civil War classic How the Steel Was Tempered (Как закалялась сталь, 1935), this is simply one more reason to fight the counter-revolutionary forces, rather than poetic justice that the Jew is fighting his former enemies. Certainly, there was no room in communist ideology for ethnic loyalties or personal crises of identity. Allegiance to the revolutionary cause was to be unswerving and total, and the individual was supposed to overcome any moral qualms or physical weaknesses. 


\section{Modernism on Two Fronts}

Henri Barbusse's Under Fire (Le feu, 1916 translated into Russian as Оzонь, 1918) and Erich Maria Remarque's All Quiet on the Western Front (Im Westen nichts Neues, 1928) did much to dispel any remaining idealistic patriotism which idealized brave young men who had enlisted in a haze of glory to die for their king and country. Babel' had briefly served on the Rumanian front and published his ironic response to tales of valor and glory in On the Field of Honor (На поле чести, 1920). But his experiences on the Soviet-Polish front shocked him into reviewing his attitudes toward the revolution and war in general. The killing and destruction was taking place, moreover, in an area densely populated by Jews, who had suffered both from bombardment and pogroms by successive occupying armies. This was an era perceived as apocalyptic, and Jewish poets and artists in particular took up the image of the crucifixion in response to catastrophe - an image of dread for persecuted Jews but one that had been used by Jewish artists and writers to symbolize the suffering of the Jewish people. For Chagall and other modernist artists, the crucifixion became an autobiographical statement of artistic and ethnic identity, and, in Calvary (1912), it was re-imagined against the background of the crucifixion of the Jewish people in the pogroms, complete with a boat of refugees. However, the crucifixion was also a common image used in anti-war satire. George Grosz has Jesus wearing a gas mask on the cross in "Maul halten und weiter dienen" ("Shut up and keep on soldiering," from Hintergrund, 1924), an image borrowed by Fridrikh Ermler in his film Fragment of an Empire (Обломок империи, 1929), set partly in the Civil War. The figure of Jesus, however, also inspired Blok, in The Twelve, against the background of the revolutionary apocalypse, and both the crucifixion and Golgotha are carnivalized in Maiakovsky's Cloud in Pants (Облако в штанах, 1918).

The crucified Jew in Babel"s "At St. Valentine's Church" draws on a trope of the anti-Jewish violence that accompanied war and revolution, the irony being that the crucifixion of the pogrom victim in Apolek's art now instills fear in the superstitious Cossacks. 


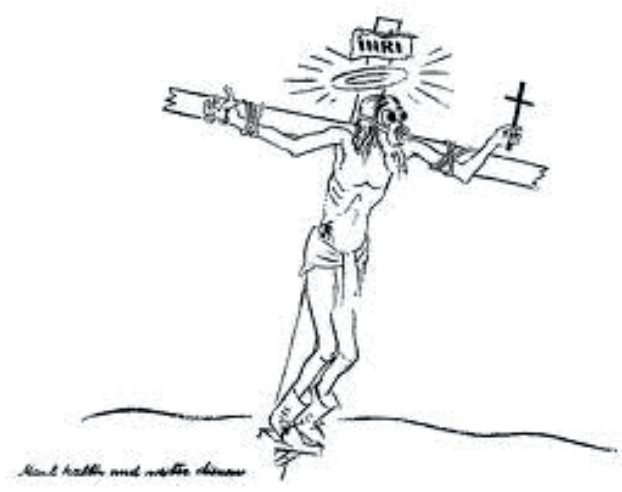

George Grosz, “Maul halten und weiter dienen"

(c) Estate of George Grosz, Princeton, NJ / VG Bildkunst, Bonn 2012

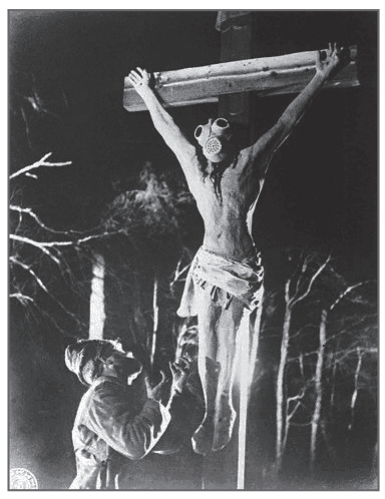

Fridrikh Ermler, Fragment of an Empire, 1929

Я видел: человека в оранжевом кунтуше преследовала ненависть и настигала погоня. Он выгнул руку, чтобы отвести занесенный удар, из руки пурпурным током вылилась кровь. Казачонок, стоявший со мной рядом, закричал и, опустив голову, бросился бежать, хотя бежать было не от чего, потому что фигура в нише была всего только Иисус Христос - самое необыкновенное изображение бога из всех виденных мною в жизни.

Спаситель пана Дюдомирского был курчавый жиденок с клочковатой бородкой и низким, сморщенным лбом. Впалые щеки его были накрашены кармином, над закрывшимися от боли глазами выгнулись тонкие рыжие брови.

Рот его был разодран, как губа лошади, польский кунтуш его был охвачен драгоценным поясом, и под кафтаном корчились фарфоровые ножки, накрашенные, босые, изрезанные серебристыми гвоздями. (Детство, 187)

I looked again: the man in the orange caftan was being pursued by hatred and was being overtaken by his pursuer. He raised his hand in order to ward off the blow that was being aimed at him, and the blood was flowing from his hand in a purple flood. The little Cossack who was standing beside me began to shout and, lowering his head, started to run off, even though there was nothing to flee from, because the figure in the niche was only Jesus Christ-the most unusual depiction of God of any I have seen in my life.

Pan Ludomirski's savior was a curly-headed little Yid with a small tufted beard and a low, wrinkled forehead. His sunken 
cheeks were touched with carmine, and above his eyes, closed in pain, curved thin, ginger eyebrows.

His mouth was lacerated, like the lip of a horse, his Polish caftan was gathered in by a precious belt, and below the caftan writhed porcelain feet, painted, naked, cut to pieces by silver nails. (Red Cavalry and Other Stories, 181)

In Avigdor Hameiri's novel The Great Madness (השיגעון הגדול, 1929), a Hungarian $\mathrm{NCO}$ in the Austrian army describes an actual crucifixion of a Jewish prisoner-of-war on the Galician front on Christmas Day, perpetrated before his eyes by drunken Cossacks who torment captured Jewish soldiers and rape local Jewish women. The virulent anti-Semitism of the Austrian officers drives the Jewish captain to a Zionist resolution of his identity crisis, whereas Liutov's alienation from his Jewish identity brings him to wish to be accepted by the men of violence, the Cossacks.

On the other side of the Polish-Soviet front, there was another modernist, Israel Rabon, who published a Yiddish novel The Street (די גאֵס) in Warsaw in 1928. The narrator, a down-and-out discharged soldier, has found casual labor in a circus after wandering the streets cold and hungry, and, waking from nightmares, he relates memories of the Soviet-Polish front. The cross is a source of terror, from which the narrator has always recoiled in superstitious dread, but when he is wounded in the foot and wanders deliriously in the frozen waste, he finds warmth and shelter in a dying Belgian drafthorse. After killing the horse, which emits a human cry, he empties its entrails and, covered in blood, crawls inside the dead beast. Only in the morning, to his horror, does he discover that he has frozen to the spot, his arms outstretched as a cross:

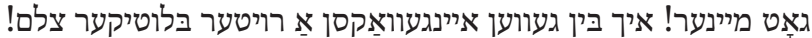

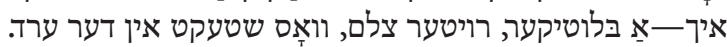 איך- אֵַ בַּוטיקער צלם אויף אַ וויס-רוסישער סטעפע! 32}

My God, I was rooted to the earth like a bloody red cross. I was a bloody cross on the Belorussian steppe. ${ }^{33}$

Having been metamorphosed into a terrifying symbol of negation of Jewish identity, the crucified soldier breaks free from his macabre 
imprisonment, but then realizes that the dead horse's eyes are accusing men of bestiality, and that he has become part of that bestiality.

The modernist literalization of metaphor here has welded the narrator to the frozen landscape that is totally bereft of any redemption, Christian or communist, and the novel closes with the narrator, who has despaired of finding work or love in Łódź, descending into the coal mines as snow covers the earth in a naturalistic ending befitting Zola. Rabon expresses the Kafkaesque estrangement of his self from a world of death and despair in the manner of Knut Hamsun's Hunger (Sult, 1890). Liutov has a similarly surrealistic experience on the Bolshevik side of the PolishSoviet front when he is dragged in his sleep by his horse to the front line. He has an erotic dream of his own death in which the mysterious Margo prays to Jesus to receive his soul, but when he awakes, he finds himself a few steps away from the front line, next to an anti-Semitic peasant, watching a pogrom in the town below, who prophesies the extinction of the Jewish people. He manages to extricate himself with difficulty, but then, as in "My First Goose," he behaves violently towards a Polish landlady in order to force her to feed him, before he has to flee Polish machine gunners who have taken up positions in the village. That premonition of death (as happened in "Crossing the Zbrucz") has brought him to witness a pogrom, but he has strangely distanced himself from his own death and that of his fellow Jews. Both Babel' and Rabon express despair and defeat on different sides of the Soviet-Polish front with modernist images of paralysis and estrangement that distance the self from any human identity.

If Bialik's elegy for the Kishinev victims In the City of Massacre ") 1904") presumed some kind of communal integrity that would survive the pogroms, or if Chernikhovsky reactivated the historical heroes and martyrs of the Jewish nation, then the estimated 200,000 victims of the massacres in 1918-1920, amid the general devastation of world war and civil war, seemed to preclude the possibility that the shtetl would flourish again. As Peter Kenez has shown, the scale and pathological intensity of the pogroms were unprecedented in history prior to the Holocaust, which was to take 
place in this region two decades later. ${ }^{34}$ The destruction of Jewish communities in Russia and the Ukraine reached such proportions that a primeval scream of atheistic nihilism could not suffice to express the collective anguish. The personal experience of the Yiddish and Hebrew expressionist poet and self-styled heir of Bialik, Uri Tsvi Greenberg (1894-1981), on the Serbian front and in a Polish pogrom in 1918 took on mythological proportions in his Golgotha ("גלגלתא", 1920): "Each morning I am nailed up again on a burning red crucifix" ("אלע אין דער פרי ווער איך אויפן ברענענדיקן רויטן צלם אויפגעשלאגןן").". Jesus joined other false messiahs in the poet's new historiography of the Jewish people, which rejected Europe as the "Kingdom of the Cross" where the dead Jews were so many crucifixions. ${ }^{36}$ His one-man protest took the typographical form of a cross, ${ }^{37}$ while his feet acted on the poet's call to a new destiny in the Land of Israel. That option was rejected by those who remained in Bolshevik Russia or emigrated to America, like Lamed Shapiro, who has left his response to war and revolution in two notorious short stories.

The hero of Shapiro's "The Cross" ("דער צלם", 1909) discovers that the pogrom has literally left the mark of the cross on the victim, who, by violence and rape, has been wrenched from the traditional ways of the shtetl. "The Cross" narrates the story of how a young revolutionary acquired the sign of the cross between his eyes, carved by a peasant when a pogrom mob broke into his home and raped his mother. The sign between the eyes is a modernistic parody of the phylacteries which are signs of the Jew's faith, the "sign between your eyes" prescribed in the Bible. The primitive brutality with which the sign of the cross is cut into his flesh marks his own transformation into a $b a^{\prime} a l-g u f$, a man of action more savage than the Benia Kriks or the tough guys in Sholem Asch's Kola Street, who likewise react with their fists to anti-Jewish violence. He becomes a bestial creature, who vengefully rapes his Russian revolutionary comrade and finds riding the roof of the railroad cars through the wild expanses of America an appropriate expression for the brute strength that, for him, can be the only way to rebuild a destroyed world. The modernist theme and style were felt sufficiently appropriate for a Russian translation to appear in the same post-revolutionary anthology of Jewish culture, Evreiskii mir, 
in which Abram Efros published his call for a Jewish modernism "Aladdin's Lamp," alongside Vaisenberg's iconoclastic story of the 1905 Revolution, A Shtetl. .8

Another story set in the years of war and revolution, Shapiro's well-known "White Sabbath-Bread" ("ווייסע חלה", 1919), is told through the eyes of a demented Russian peasant conscript, Vasily, who has been incited by anti-Semitic propaganda and has run amok together with thousands of fellow soldiers with the break-up of the Russian army in 1917. Confronting the white breast and shoulder of a Jewish woman, he is driven wild by the white khallah he once tasted, and now recognizes as the flesh of the Jews who crucified the Christian god and who are responsible for all Russia's troubles. He attacks the woman and bites into her white "khallah" - bread and flesh, in a parody of the Christian transubstantiation. The shock and horror at the desecration of the ultimate divine image (tselem elokim)-man-is reinforced by the human sacrifice at the end of the story, but it also rereads the midrash of the heavenly altar on which Jewish martyrs were sacrificed as a travesty of divine mercy and justice. "White Sabbath-Bread" ends with a blasphemous liturgy of blood sacrifice that approaches an erotic fusion of the blood of perpetrator and victim:

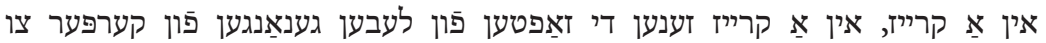
קערפער-

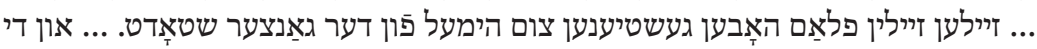
צאֵַרטע טיילען, שענקעל און ברוסט, האָט געקראָּנען דער כהן.

In a circle, in a circle, coursed the juices of life from body to body. . . Pillars of smoke and pillars of fire rose to the sky from the entire town.... And the tender parts, thighs and breasts, were the portion of the priest. ${ }^{40}$

Such an atavistic burst of what can only be described as an animal Passion symbolized for Shapiro the final meaning of the pogroms; in other stories by Shapiro, instead of heroic acts of revenge by Jewish revolutionaries, there is bestiality and suicide. In "The Kiss" "(דער קוש") a Jew bites off the toes of his attacker, while in another story, "The Jewish Government" ("די יודישע מלוכה"), Shapiro shows how the primitive wave of animal hatred and violence against 
the Jews awakens heretical rebellion in a modernist inversion of traditional patterns of redemption and martyrdom.

The impact of the pogroms in the Ukraine on Jewish modernist writers is felt acutely in the long poem The Heap (די קופע, 1921) by Peretz Markish. This is an obscene montage of the 'aqeda (Binding of Isaac), Golgotha, and (as in one of Issakhar Ber Rybak's Pogrom Series of 1918) giving back the Tablets of the Law at Mount Sinai. The stinking heap of bodies piled up, one on top of the other, in the marketplace of the Ukrainian town of Horodysche (Horodishtch in Yiddish) the morning after the Day of Atonement in 1919, overshadows all images. The Jews prayed for Divine mercy on this holiest day in the Jewish calendar, but the poet sees in the bloody corpses the next day neither the redemption of the paschal sacrifice nor the covenantal blood of circumcision. The Jews killed in the name of Jesus are sold, as Jesus was, for a purse of silver:

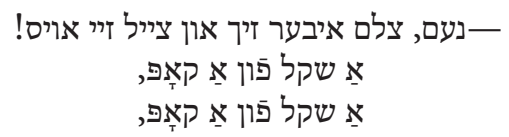

Come! cross yourself and count them.

A shekel a head,

A shekel a head.

The irresolvable paradox is that this kaddish (which almost anticipates the modernity of Allen Ginzberg's unorthodox mourners' prayer), written in the style of Maiakovsky, is addressed to a God whose divinity is denied. ${ }^{42}$ Markish repudiated the martyrology of centuries of Hebrew and Yiddish responses to catastrophe, and went further than Bialik's mocking tone in his Kishinev dirge, "On the Slaughter," for the ritual slaughter is here emptied of all meaning of the sacrifice of holy innocents in the cynical description, in the prologue of Markish's poem, of "heavenly tallow" ("הימלשער חלב"): the animal fat offered on the altar has become a modernist image of indifferent skies. The aesthetics of modernism fragmented the mythological texts into a new poetic sense of language and existence in a post-apocalyptic world, where, as in T.S. Eliot's The Waste Land (1922), theology could be both destructive and deconstructive, both confessional and despairing. As Amelia Glaser has shown, 
much more than the dead of Horodishtch is being summoned up in the black heap of bodies in the sacrilegious "tabernacle" of the marketplace, where the corpses are all the merchandise there is; an entire world has been turned upside down in the devastation that swept Russia and the Ukraine in 1918-1920.43

In Babel"s "Gedali" the marketplace is empty except for old Jews with prophetic rags.

Вот передо мной базар и смерть базара. Убита жирная душа изобилия. Немые замки висят на дотках, и гранит мостовой чист, как дысина мертвеца. (Детство, 125)

Here before me is the bazaar and the death of the bazaar. Slain is the rich soul of abundance. Mute padlocks hang on the stalls and the granite of the paving is as clean as the bald pate of a dead man. (Red Cavalry and Other Stories, 116)

The economic life of the Jews, desperate as it was under Tsarist oppression, has now been wiped out by communist "justice" and by pogroms on an unprecedented scale perpetrated by Whites, Poles, and Ukrainians.

Red Cavalry shared its theme of the price Jews paid for Bolshevik victory with Khaim Hazaz's Hebrew tale of a shtetl during the Civil War, From Here and There (מזה ומזה, 1924), which, as I have noted in an earlier chapter, was lauded in the Soviet Hebrew communist journal Breshit for its description of the rejection of old shtetl ways by the young Jewish commissar. ${ }^{44}$ On the face of it, Liutov makes no allowances for the fate of the old Jewish world in his mouthing of dogmatic propaganda, but he ignores a plea for justice that questions the violence of the revolution:

- Революция - скажем ей “да", но разве субботе мы скажем “нет"? - так начинает Гедали и обвивает меня шелковыми ремнями своих дымчатых глаз. - “Да”, кричу я революции, “да", кричу я ей, но она прячется от Гедали и высылает вперед только стрельбу...

- В закрывшиеся глаза не входит солнце, - отвечаю я старику, - но мы распорем закрывшиеся глаза...

- Поляк закрыл мне глаза, - шепчет старик чуть слышно. Поляк - злая собака. Он берет еврея и вырывает ему бороду, ах, пес! И вот его бьют, злую собаку. Это замечательно, это - 
революция! И потом тот, который бил поляка, говорит мне: Отдай на учет твой граммофон, Гедали... - Я люблю музыку, пани, - отвечаю я революции. - Ты не знаешь, что ты любишь, Гедали, я стрелять в тебя буду, тогда ты это узнаешь, и я не могу не стрелять, потому что я - революция...

- Она не может не стрелять, Гедали, - говорю я старику, потому что она - революция...

- Но поляк стрелял, мой ласковый пан, потому что он контрреволюция; вы стреляете потому, что вы - революция. А революция - это же удовольствие. И удоводьствие не дюбит в доме сирот. Хорошие дела делает хороший человек. Революция - это хорошее дело хороших людей. Но хорошие люди не убивают. Значит, революцию делают здые люди. Но поляки тоже здые люди. Кто же скажет Гедали, где революция и где контр-революция? Я учил когда-то талмуд, я люблю комментарии Раше и книги Маймонида. И еще другие понимающие июди есть в Житомире. И вот мы все, ученые люди, мы падаем на дицо и кричим на-голос: горе нам, где сладкая революция?.. (Детство, 126)

"The revolution - we will say yes to her, but will we say no to the Sabbath?" Thus begins Gedali entwining me in the silken throngs of his smoked eyes. "Yes, I hail the revolution, yes, I hail it, but it hides from Gedali and sends ahead of it naught but shooting."

"The sun does not enter eyes that are closed," I reply to the old man, "but we will rip open those are closed eyes."

"The Pole closed my eyes," the old man whispers, barely audibly, "the Pole, the vicious dog. He takes a Jew and tears out his beard, ugh, the dog! And now he is being beaten, the vicious dog. That is wonderful, that is the revolution. And then he that has beaten the Poles says to me, 'Hand over your gramophone to be registered, Gedali...' 'I love music, pane,' I reply to the revolution. 'You do not know what you love, Gedali. I will shoot at you, and then you will find out. I cannot do otherwise than to shoot, because I am the revolution..."'

"It cannot do otherwise than to shoot, Gedali," I say to the old man, "because it is the revolution."

"But the Pole shot, my dear sir, because he was the counterrevolution: you shoot because you are the revolution. But the revolution-that is pleasure. And pleasure loves not orphans in the house. Good deeds are done by a good man. But good men do not kill. That means that the revolution is being made by bad men. But the Poles are also bad men. So who will tell Gedali where is the 
revolution and where is the counter-revolution? Once upon a time I studied the Talmud. I love the commentaries of Rashi and the books of Maimonides. And there are also other men of understanding in Zhitomir. And so we all, we learned men, fall upon our faces and cry aloud, 'Woe to us, where is the sweet revolution? ...'" (Red Cavalry and Other Stories, 117-18; slightly revised)

Liutov's mimicry of revolutionary discourse opposes the justice of the revolution to the blindness of the bourgeoisie, but the irony is that he cannot see what the old Jewish shopkeeper blinded by Poles in a pogrom sees: the contradictions of a violent revolution that dispossesses the liberated Jews in the name of communism. Inspired perhaps by the more down-to-earth idealism of a Jewish storekeeper, whom Babel' met in Zhitomir, who wished for one government that would do good (Собрание сочинений II, 223), Gedali's homespun philosophy is the Judaic version of utopian messianism - an impossible "International of Good People," that will distribute first-class rations to everybody. Yet when Gedali departs alone for the synagogue, this is a direction Liutov does not take. Gedali is unable to understand why the Jews are suffering at the hands of both Revolution and Counter-Revolution. Why are the Jews, who welcomed their delivery from the hands of the Poles and White Cossacks, treated as enemies and subjected to looting and requisitions by the Reds? Where is the universal salvation promised by the Communists? Liutov gives Gedali no answer, and the historical injustice done to the Jews, needless to say, cannot be detailed, given the circumstances of publication in Soviet Russia in the mid-1920s.

In Hazaz's novella, however, the young Jewish commissar holds to a more relentless ideological position in his verbal duel with the pious old Jew. Reb Natan-Netta Cohen has reached his wit's end trying to feed his family in a world turned upside down, where the shtetl has been divided between bourgeoisie and proletariat, fathers and sons, and it is difficult for former tradesmen like him to make a living. Turning to Motl Pikeleni, the Cheka agent, his plea rebutted as "Counter-Revolution" and threatened with prison. The traditional Jew can no longer count on solidarity among Jews, their flesh and blood, when an internationalist ideology decrees the Jews have no separate rights as a people: 


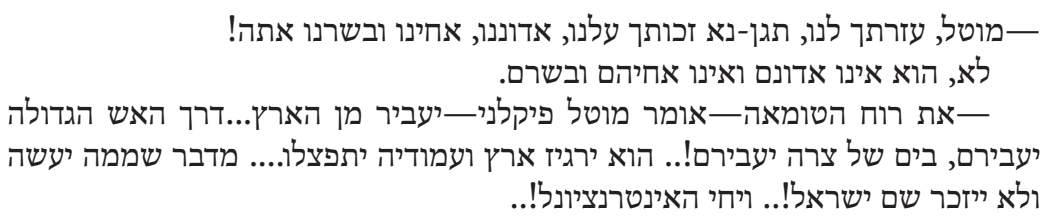

"Motl, help us, we beseech you to cast your protection over us, our lord and master, you are our brother!"

No, he is no lord and master, and he is no brother of theirs.

"The impure forces of a rotten system," says Motl Pikeleni, "will be swept from the world... by means of a great fire, in a sea of distress! It will shake the world and its pillars will split asunder... It shall become a desolate wilderness, and the name of Israel shall be heard no more! Long live the International!..." 45

The young commissar Motl Pikeleni is all-powerful, armed with a pistol, and vengeful. The religious celebration of Passover that greets the Red Army cannot postpone the passing of the shtetl's traditional way of life. And yet it is Motl who is greeted as a hero when he saves the shtetl from the pogromshchiki, and the story ends with Reb Natan-Netta's son Henekh, the head of the local Revolutionary Committee, being given a funeral befitting a communist fighter, to the accompaniment of the International; the old man is left outside the cemetery, saying kaddish.

Yiddish novels of the Civil War, such as Peretz Markish's epic poem Brothers (ברידער, 1929) and the first volume of his novel, Generation Goes, Generation Comes (דור אויס, דור אין), can be compared with Babel"s descriptions of the Soviet-Polish front, and a similar skaz narrative is found in Dovid Bergelson's descriptions of bestial savagery during the pogroms in the Ukraine. As Harriet Murav explains, in contrast to the ethos of socialist ideals of forging a new self in Soviet Civil War fiction, these works blurred the distinction between the political and the personal and were burdened by Jewish memory of war and revolution, of the thousands massacred, so that "the trope of the festering wound, the open, flowing body, and the 'mound' overwhelm all boundaries to become dominant elements of the artistic text. It is not only the destruction of the past they lament but, in addition, the failure of the revolution to give birth to something new." ${ }^{46}$ So, while Markish shows a 
Jewish Bolshevik reforming himself into an internationalist in Brothers and identifying with the new Soviet land, he cannot help mourning the destruction of the Jewish communities of the Ukraine in the same Civil War which made him what he is. Ultimately, the body and nature overflow in excessive, grotesque images reminiscent of Red Cavalry, postponing any celebration of a new beginning. ${ }^{47}$

In the novella "Civil War" ("בירגערקריג") by Dovid Bergelson, in his collection Storm Days (שטורמטעג, 1927), a modernist narrative tells of two Bolshevik fugitives from Petliura, Botchko and Zeek. ${ }^{48}$ While the focus moves away from the Jewish perspective to a stream of consciousness of rapacious Russian deserters, there is no mistaking the ominous atmosphere of dread and terror that grips the Jews of Zvil and Aleksandrovka. When, at the end of the novella, the renegade Jewish son of the shtetl, Leyzerka, reappears with Bolshevik insurgents, expressing only hatred for his former fellow Jews, we understand how far the Jewish Communists have cut themselves off from their suffering brethren. The distancing from any moral perspective on rape and murder of Jews - a stance supposedly in favor of a communist internationalism - is similar to Babel"s somewhat more shocking, but no less sanguine, rendering of a Cossack lad's attitude toward a gang-raped Jewish woman in "At Bat'ko Makhno's" ("У батьки нашего Махно," 1924), in which Kikin is more interested in his prospects in the partisan band and fooling around than Rukhle's feelings; her point of view is totally muted. The reader's judgment, however, is manipulated from the outset when the narrator declares that he wanted to see what a woman raped by six of Makhno's men looked like and proceeds to describe her in bestial terms, likening her odorous, corpulent body to the fertile earth of the Ukraine:

Это была толстуха с цветущими щеками. Только неспешное существование на плодоносной украинской земле может налить еврейку такими коровьими соками, навести такой сальный глянец на ее лицо. Ноги девушки, жирные, кирпичные, раздутые, как шары, воняли приторно, как только что вырезанное мясо. (Собрание сочинений III, 113-14) 
She was a fat girl with blooming cheeks. Only a tranquil life on fertile Ukrainian soil can douse a Jewish girl in such bovine juices, lend her face such a lusty gloss. The girl's legs, fat, brick-red, bulging like globes, gave off the luscious stench of freshly carved meat... (Complete Works, 337)

This amoral detachment (worthy of Maupassant's Normandy tales), which assimilates the viewpoint, though not the language, of the peasant soldiers, focuses on the unflinching gaze of the voyeura gaze that Babel' used to explore his fascination with human nature, as in a 1915 story later entitled "Through the Fanlight" ("B щелочку"), or another Civil War story "Tale of a Hardworking Woman" (“Старательная женщина"). However, instead of erotic arousal, "At Bat'ko Makhno's" delivers only moral outrage.

The apocalyptic vision was commonplace in Yiddish and Hebrew prose and poetry that responded to the catastrophe which struck East European Jewry in these years of war and revolution, ${ }^{49}$ but the influence of European modernism was also prevalent, and in Babel"s Red Cavalry we can recognize similar stylistic turns and a similar aesthetic temperament that (along with the influence of Turgenev and Chekhov) would later characterize the clash of ideals and violence in Hemingway and other American modernist classics. ${ }^{50}$ Babel' remained the literary voyeur who achieved aesthetic distance without compromising the unspoken moral stance. In the 1930s, he attempted to restrain the stylistic exuberance and stark juxtapositions of Red Cavalry in order to convey the human cost of one of the most grandiose and cruel experiments in human history, the collectivization campaign of 1929-1933. 


\section{7 \\ A Voyeur on a Collective Farm}

\section{Closely Observed Farms}

In1920, Babel' went to war, suggests Odessajournalist Elena Karakina, much like Josephus Flavius, as Leon Feuchtwanger portrayed the Jewish general who went over to the Romans, as a correspondent to history, in order to witness the most terrifying cruelty without flinching, without betraying his empathy and kinship with the victims. ${ }^{1}$ However, Josephus' ethical position remains controversial. There can be little doubt as to Babel"s sympathies when writing his 1920 Diary, nor should we mistake the moral position of the author in Red Cavalry. But the stories Babel' wrote about collectivization (which were to form part of a book, Velikaia krinitsa) ${ }^{2}$ and about industrialization - of which we have only one, "Oil" ("Нефть", 1934) - do leave us with disturbing questions about the ethics of narration, not least the apparent absence of an authorial position. By the onset of the campaign of forced collectivization, Babel' could have no delusions, for all his idealism. And yet there is scarcely any evidence in these stories that he ever betrayed his misgivings or his personal feelings about what was done in the name of the building of socialism.

Babel' had the opportunity to observe collectivization at close hand in Molodenovo, where his life was idyllic, both because of its proximity to Gor'ky and the quiet it afforded to get on with his work uninterrupted, not to mention bathing in the Moskva River in the summer. Sometimes he would take a scythe and help with the harvesting. ${ }^{3}$ The peasants affectionately called him Isai Imuilovich, and he worked for a while as secretary of the village council, as 
well as observing breeding on the stud farm. ${ }^{4}$ On 16 February 1930, Babel' informed his family abroad that he was leaving for an area of intense collectivization in the Borispol' district in the Kiev region, which was transforming Soviet agriculture and village life. He would never forgive himself, he wrote, if he missed seeing this process with his own eyes "both because it is interesting in itself and because it has a significance transcending anything we have seen." ${ }^{5}$ To his schoolfriend from Odessa, Isai Livshits, he wrote from Borispol' on 20 February 1930, that he found this area of intensive

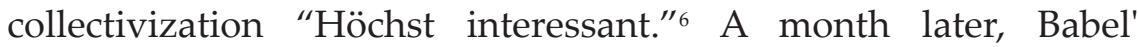
returned to Kiev sick and exhausted. His friend M. Y. Makotinski, who worked with him at the VUFKU film studios, was at this time expecting NKVD agents to arrest him and was frightened out of his wits by a furious pounding on the door of his apartment in the middle of the night. Only after some time did he open the door to discover Babel' covered in snow, shivering with cold. He had been following the collectivization process and was shaken by what he saw in village after village: You cannot imagine! It is inexpressible, what I have observed in the village! And not just in one village! It is impossible to even describe! I do not understand an-y-thing!" (“Вы себе представить не можете! Это непередаваемо-то, что я наблюдал на селе! Инев одном селе! Это и описать невозможно! Я ни-че-го не по-ни-маю!" $)^{7}$

After observing the collectivization campaign, and before he returned to Moscow in April, Babel' visited the construction site of the huge industrial complex on the Dnieper and in later years he travelled round mines, farms, and factories all over the country. Later he was to tell Ervin Sinkó, his Hungarian émigré neighbor in Moscow, of the eerie silence of villages where no dog dared bark. ${ }^{8}$ And this is how "Gapa Guzhva," the first chapter in Babel"s projected book, Velikaia Krinitsa, ends:

Безмолвие распростерлось над Великой Криницей, над плоской, могильной, обледенелой пустыней деревенской ночи. (Собрание сочинений, III, 158)

Silence spread over Velikaia Krinitsa, over the flat, sepulchral, frozen desert of the village night. (Complete Works, 651) 
Nevertheless, in his letters to his family abroad, which were filled as always with financial and family anxieties and were written with the censor in mind, Babel' effused praise for the success of collectivization in the Caucuses, which was bringing unprecedented economic benefits and limitless vistas on an impressive scale (such as the largest poultry farm in the world), despite the "hardships" suffered. ${ }^{9}$ After going down a mine in Gorlovka (in the Don Valley) he enthused about industrialization: "The spirit of hope and triumph here now is greater than at any time during the sixteen years since the Revolution." ${ }^{10}$ On another trip to the area, collecting facts for work in progress at the height of the Stakhanovite movement, he spoke of "the mighty energy and vigor seething in this region, which is the real steel, coal, and electric heart of our great country." ${ }^{11} \mathrm{He}$ also visited the Jewish agricultural colonies in the Ukraine and Crimea under the auspices of OZET, the Jewish agricultural settlement program. However, Babel' does not seem to have written anything about his impressions, although other writers commissioned for such trips did produce glowing accounts of the remarkable phenomenon of Russian Jews working the land, or the resettlement of Jews in Birobidzhan and the Sovietization of the Tat (Mountain) Jewish farmers. ${ }^{12}$ On a tour of the Kiev region in fall 1935, Babel' admired the transformation of a wilderness into modern farmland with electricity. ${ }^{13}$

Later, he worked on the glossy propaganda magazine USSR in Construction, distributed around the world in several languages, and helped to produce an entire issue devoted to the sugar beet harvest in the Kiev region. ${ }^{14}$ Besides the special issue on Gor'ky, which he planned and edited, ${ }^{15}$ Babel' helped produce (according to Usher Spektor) an issue on industrialization in the Donbass in 1939, but is not mentioned in the credits, possibly because by then he was a "non-person". ${ }^{16}$ The associate editor of USSR in Construction was an old friend from Odessa, Evgeniia Khaiutina (who had married a White officer and lived in Berlin, and was now the wife of Ezhov, the secret police chief, who suspected Babel' of having an affair with her). USSR in Construction presented an idyllic picture to the West and helped prevent sympathizers and celebrities abroad guessing at the reality of forced collectivization and industrialization. 
De-kulakization of peasants in the Donetsk region, 1930s
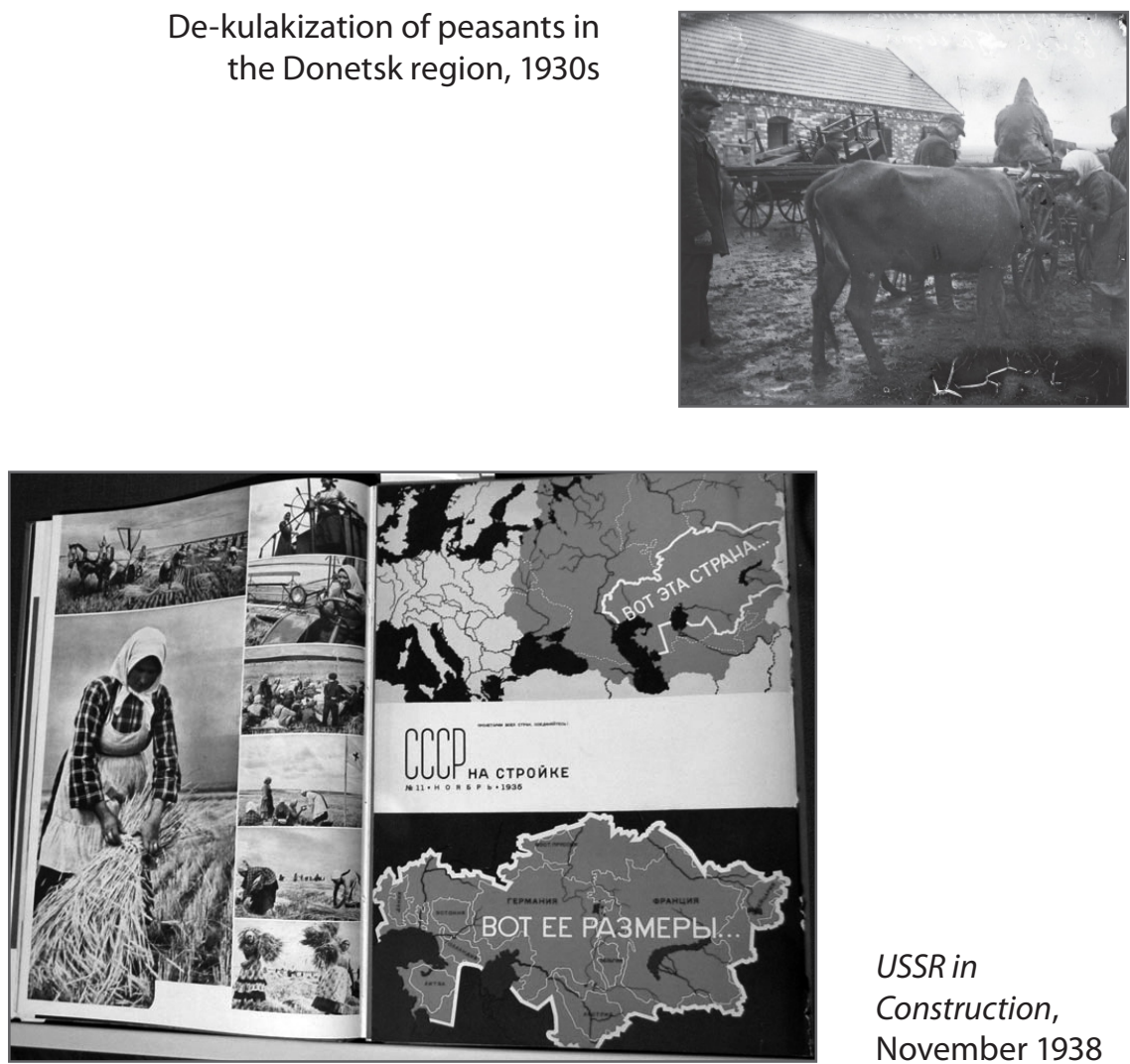

USSR in

Construction,

November 1938

Few foreigners ever got the chance to see the rotting corpses, the orphanages and penal colonies for children whose parents had been taken away, or the hard-labor convicts. When an important delegation visited, a Potemkin village was organized, the horror hidden away. ${ }^{17}$ We shall never know how uneasy Babel' was about collusion with the covering up of the harrowing truth.

The intense collectivization which began in 1929 came with the consolidation of Stalin's power, after the defeat of Trotsky on the left and the crushing of Bukharin and rightist opposition. Political pressure, administrative measures, and forced requisition of grain to meet shortfalls in production were effective in ensuring that peasants voted for collectivization of their villages. The targets for collectivization set by the Five Year Plan were grossly inflated and repeatedly increased, while, in the absence of a strong Party base 
locally, officials were sent to enforce production quotas accompanied by mobilized Party activists, who were not given adequate agricultural training and many of whom had little familiarity with peasant life. The activists were told they were being sent into the countryside for a month or two and they were not to be afraid of taking extreme measures in procuring grain:

\begin{abstract}
"You must assume your duties with a feeling of the strictest Party responsibility, without whimpering, without any rotten liberalism. Throw your bourgeois humanitarianism out of the window and act like Bolsheviks worthy of Comrade Stalin. Beat down the kulak agent wherever he raises his head. It's war-it's them or us! The last decayed remnant of capitalist farming must be wiped out at any cost!"18
\end{abstract}

The unrealistic targets of mass industrialization and collectivization were, moreover, based on political aims (many economists were forced to recant or lost their positions).

In the next stage of forced collectivization, announced by Stalin in November 1929, whole villages and districts were to be collectivized. It is not clear whether the Soviet leadership foresaw the disastrous results of the crippling of peasant leadership and the destruction of the most efficient elements of agriculture, but what Robert Conquest has termed the "terror-famine" was horribly effective in establishing total Party control over the country and also wiping out remaining Ukrainian aspirations for independence. ${ }^{19}$ Together with the elimination of the Ukrainian cultural and intellectual leadership, the forced collectivization of the Ukraine destroyed an entire way of life. Babel"s story "Gapa Guzhva" tells of how the village, whose real name Babel' prudently changed, celebrates for the last time its almost forgotten traditional lifestyle and rhythms. ${ }^{20}$ The story opens with the village whore, Gapa Guzhva, a kind of local Liubka the Cossack, gallivanting and carousing at the celebration of six weddings. But the gaiety and abandon vanish overnight with the coming of enforced collectivization. The church bells are taken down, the grain is requisitioned, and Rakhivna, a wandering seer, takes refuge at Gapa Guzhva's, warning her of the impending visit of priests from the free church in Antioch, who are coming to spread 
the news of the end of Soviet power and its punitive destruction. She is later arrested and presumably deported or executed. Rakhivna reports that the Voronkov judge collectivized his village overnight and put nine kulaks in the cooler, who were found hanged the next morning. When Gapa faces the Voronkov judge, who has come to impose deportations and confiscation in the name of the authorities, she goes to the village council and jokes about collective life requiring everyone to sleep under one blanket. She has, apparently, been persuaded to un-sign herself from the collective farm by the other villagers. Later, she asks Judge Osmolovsky whether there will be any place for whores in the new order.

- Житье будет блядям или нет?

- Будет, - сказал судья, - только другое, лучшее. (Собрание сочинений, III, 157)

"Won't the whores be allowed to earn their living?"

"They will," the judge said, "But in a different, better way." (Complete Works, 651)

She goes out, fingering her necklace, and the icy night throws itself down on her. The equivocal ending leaves a chilling sense of foreboding about the future, and it is not clear whether Gapa Guzhva's spirited defiance has been muted into resignation, or (as Carol Avins infers) accommodation. ${ }^{21}$ The deathly predatory silence that envelops the village does not leave room for a redemptive ending which would fit a Soviet clichéd makeover into the new life, or an Easter-time renewal of life.

The definition of "kulaks" as a class enemy could include wealthy peasants (even Communists who had prospered during the NEP years) and anyone resisting the requisition of property. Individual kulaks had been exiled from Ukrainian villages and Cossack settlements throughout 1929, but, in February 1930, a decree was issued ordering the elimination of the kulaks as a class. ${ }^{22}$ Although tax lists were cited, the kulaks were mostly impoverished and yet condemned as kulaks. Henceforth the class enemy was to be identified ideologically, not economically, and once designated as a kulak, the peasant's fate was sealed, often also that of his family. The first category of hard-core kulaks (including former White 
soldiers) was to be arrested and executed or imprisoned; the second group included the families of those executed or imprisoned who were to be deported to remote areas; the last group was to be evicted and conscripted to labor or settled elsewhere, but was liable to imprisonment on the slightest infraction or on suspicion of opposing collectivization. Despite the pretense of voluntary association, many peasants were banished for refusing to join the collective farm; after witnessing a brutal round-up of recalcitrant peasants, one Party activist realized that the violent extortion and coercion were being abetted by the regional Party committee: "So this was the liquidation of the 'kulaks as a class'! A lot of simple peasants being torn from their native soil, stripped of all their worldly goods, and shipped to some distant lumber camps or irrigation works." ${ }^{23}$ Party activists had to be mobilized to help the GPU with the mass arrests. Resistance was useless in the face of armed officials, but there were reports of peasants selling or destroying their cattle and property and running away, many fleeing to factories in the cities in the hope of earning a crust of bread and escaping detection. An estimated thirteen million were deported. ${ }^{24}$ This is Babel"s description in his story "Kolyvushka" of Kolyvushka after he has been informed he will be deported:

Кобыла подтащила к нему розвальни, высунула язык и сложила его трубочкой. Дошадь была жереба, живот ее оттягивался круто. Играя, она ухватила хозяина за ватное плечо и потрепала его. Иван смотред себе под ноги. Истоптанный снег рябил вокруг пня. Сутулясь, Кодывушка вытянул топор, подержал его в воздухе, на весу, и ударил лошадь по лбу. Одно ухо ее отскочило, другое прыгнуло и прижалось; кобыла застонала и понесла. Розвальни перевернулись, пшеница витыми полосами разостлалась по снегу. Лошадь прыгала передними ногами и запрокидывала морду. У сарая она запуталась в зубьях бороны. Из-под кровавой, льющейся завесы вышли ее глаза. Жалуясь, она запела. Жеребенок повернулся в ней, жила вспухла на ее брюхе.

- Помиримось, - протягивая ей руку, сказал Иван, помиримось, дочка... (Собрание сочинений, III, 160)

The mare came over to him dragging a sledge behind her. She hung out her tongue and then curled it up. She was with foal and her belly 
was heavily swollen. She playfully nudged and nuzzled her master's shoulder. Kolyvushka looked down at his feet. The trampled snow lay in ripples around the tree stump. Hunching over, Kolyvushka grabbed the axe, held it up high in the air for an instant and brought it down on the horse's forehead. One of her ears lunged back, the other fluttered and then slumped. She moaned and bolted to the side, the sledge toppling over and wheat flying in curved ribbons over the snow. She reared her forelegs into the air, tossing back her muzzle, and got caught in the spikes of a harrow by the shed. Her eyes peered out from under a streaming curtain of blood. She sang out in lament. The foal turned within her. A vein puffed up on her belly.

"Forgive me," Ivan said, stretching out his hand to her, "forgive me, my one and only." (Complete Works, 653-54)

This scene, which Avins likens to the almost religious frenzy with which the peasant Mikolka kills the mare in Crime and Punishment, ${ }^{25}$ expresses the utter despair that was released in the violence omitted from the official record of collectivization, as well as the powerlessness of subjugation and humiliation, and yet Babel"s precise observation nevertheless injects a human pain into the suffering of the animal: "She curled back her upper lip in despair" (Complete Works, 654; “Верхняя губа ее запрокинулась в отчаянии" [Собрание сочинений, III, 160]). As in the description of Afon'ka Bida's dying horse in Red Cavalry, cruelty is deflected into the response of a dumb animal. Observation is dispassionate, judgment is reserved. When Kolyvushka's relatives stop him smashing up the farm machinery, he puffs and pants as if he had been working hard. His hair has turned white. Kolyvushka is excluded from the meeting as a kulak and tries to rouse support from the rabble. Adrian Morinets, the village council committee member who accompanies the officials requisitioning Kolyvushka's home, voices his willingness to let him stay. Yet when the hunchback Zhitniak, the collective farm chairman, threatens to go and get Timish's gun and shoot him, Kolyvushka leaves the village, never to be seen again.

Those who "voluntarily" handed over their grain and joined the collective farm evidently "decided to face starvation at home rather than banishment to the unknown." ${ }^{26}$ The decisions were generally 
made by outsiders (regional Party officials, Komsomol members, soldiers, and workers) under directions from Moscow. In Mikhail Sholokhov's Virgin Soil Upturned (Поднятая целина, 1932), Semion Davidov, a Putilov metal worker mobilized to set up a collective farm on the Don, Gremiachii log, cites Stalin's speech in Pravda to refute the local village council chairman's Leninist position and, overcoming Nagulnov"s more strong-arm methods, uses his powers of persuasion to win over the middle and poor peasantry and liquidate the kulaks. Anti-Soviet intrigue simmers, but enemies are clearly identified and revolt quelled with cunning and skill. The pretentious and treacherous former White officers scheming to bring back the ancien régime, pale next to the hearty farm workers who, like the amiable ex-sailor Davidov, are excited at any prospect of manual labor, and relish bringing in rich harvests. Under the caring and thoughtful guidance of the representative of the regional Party committee, comrade Nesterenko, an old fighter ready to sacrifice himself for the cause, Davidov uses the authority of the Party to get the laborers to comply with his orders, under threat of being branded subversive counter-revolutionaries, and former friends and neighbors are treated as class enemies. He gets them to work on rest days and to desist from bringing a priest to pray for rain, he drags the women back from going to church, and takes care of hunger and want. Faced with the parched virgin earth, he never despairs or gives up. As a dedicated Communist and respected chairman of the collective farm, he knows he must extricate himself from the snares of Lushka, a wanton young woman in the village estranged from her husband, the communist nucleus secretary Nagulnov, and secretly in love with the banished kulak's son Timofei, who has returned from exile to wreak vengeance. Betrayal is everywhere.

There is little mistaking the jubilation in Sholokhov's novel with which the kulaks are evicted from their homesteads and every single piece of property requisitioned. There is no sympathy for the dispossessed families, and resistance serves to legitimize arrests and deportation. Not all Party activists could stomach unflinchingly the heart-wrenching scenes of families being thrown out of their homes and all their goods confiscated (sometimes even clothes they were 
wearing). At one point in Sholokhov's novel, Andrei Razmetnov refuses to turn out any more kulaks:

- Я не обучен! Я... Я... с детишками не обучен воевать!.. На фронте - другое дело! Там любому шашкой, чем хочешь... И катитесь вы под разъэтакую!.. Не пойду! ... У Гаева детей одиннадцать штук! Пришли мы - как они взъюжались, шапку схватывает! На мне ажник волос ворохнуяся! Зачади их из куреня выгонять... Ну, тут я глаза зажмурил, ухи заткнул и убег за баз! Бабы по-мертвому, водой отливали сноху... детей... Да ну вас в господа-бога!.. ${ }^{27}$

"I am not trained. I... I... I haven't been trained to fight children. It's a different matter on the front. You can cut down who you like there! You can all go to hell! But here-I'm not going on. ... Gayev has eleven children. When we came they all began to scream and shout in wild terror. My hair stood on end! We began to turn them out of the house, but then I had to shut my eyes and my ears, and run away. The women lying in a faint, pouring water over them... the children... you can all go to hell!" 28

He is silenced by Davidov's reminder that there was no pity for workers before the Bolshevik Revolution, when his mother had to sell her body to buy bread, and there can be no pity for class enemies now. But when women revolt and seize the grain, Davidov is beaten and the grain is only returned after the use of force.

Discipline was strict, and chairmen of village councils or officials who did not comply with de-kulakization quotas, or who helped the victims, were replaced (as is Ivashko, the regional Party committee representative, in Babel"s story "Kolyvushka"). Bukharin testified how much the collectivization campaign brutalized Party workers, inuring them to any humanity as they became efficient parts of the same killing machine that was to destroy so many lives in the Great Terror; those who participated "became professional bureaucrats for whom terror was henceforth a normal method of administration." ${ }^{29}$ Some, it is true, were stunned by the revelation that "excesses" were not local incidents but part of the system, yet were consoled by the overall achievements of modernization of agriculture and industry in the first Five Year Plan (no mean feat given Russia's backwardness). In any case, they had no way 
of communicating what they had seen in the village. ${ }^{30}$ Very often, insubordination or non-compliance would mean trouble for both themselves and those they were trying to help. Yet most of the Party activists obeyed orders unquestioningly, having been told that this was a war against a cunning enemy sabotaging collectivization and the necessary modernization of agriculture. Some were sincerely enthusiastic about doing their bit for the communist cause, as if it were the civil war again, and some were filled with hatred for the peasantry.

I became a member of the Party activist committee too. The activist committee included all kinds - those who believed the propaganda and who hated the parasites and were on the side of the poorest peasantry, and others who used the situation for their own advantage. But most of them were merely anxious to carry out orders from above. ... And the worst were not those who really believed the destruction of the kulaks would bring about a happy life. ... The most poisonous and vicious were those who managed to square their own accounts. They shouted about political awareness - and settled their grudges and stole. ${ }^{31}$

Those who followed their conscience and resigned from the Party were denounced in Pravda, and some were tried for sabotage. There was nevertheless some peasant opposition, occasionally violent, and sporadic revolts, which were ruthlessly repressed. ${ }^{32}$

In the face of resistance, Stalin called a tactical retreat in his article "Giddy from Success" in Pravda, 2 March 1930, in which he blamed local officials for excesses and distortions which threatened the loyalty of the peasants to the state. However, Stalin was not to be deterred from putting an end to the freedom of the peasantry, who began to regard themselves as Soviet serfs. As a concession, peasants were allowed a private allotment, but the option to leave the collective farm was restricted and unattractive. When peasants opting out of the collective farm demanded the return of livestock and equipment, they were offered an inferior exchange or were told they belonged to the fund of the collective farm. When, in Sholokhov's Virgin Soil Upturned, Naglunov, whose expulsion from the Party has been reduced to a reprimand for misdemeanors, argues they are better off without those who want to opt out, he is told his 
political growth is incomplete and he should not shoot his mouth off about the "excesses" and "deviations" of the regional committee. ${ }^{33}$ Tools and machinery were in the hands of the state, and the MTS tractor stations were poorly equipped, so that the high targets of grain procurement in 1932, enforced severely by draconian laws that included punishment by death for minor offences, caused real hardship and mass famine. ${ }^{34}$ Moreover, despite the propaganda line about the dire necessity for the transformation of Soviet agriculture, and for this new social revolution, there was no plan of how goals were to be achieved. Stores were neglected and provisions left rotting. Millions were starving to death or subsisting on nettles, rodents, and horse manure (there were also reports of cannibalism), while grain was being shipped out and milk turned into butter for export. After Stalin's jubilant declaration that collectivization had been completed in 1933, Party activists were once more mobilized to force the remaining peasants, many barely able to walk, to bring in the harvest, this time under the surveillance of the secret police, who hampered efforts to feed local peasants bringing in the harvest and threatened activists with expulsion from the Party or arrest if they did not obey orders. ${ }^{35}$ Some seven million are thought to have perished in the Ukrainian mass famine.

The starving people were left to themselves. The state has abandoned them. In the villages people went from house to house, begging from each other. ... And occasionally they were given a handful of bran or a couple of potatoes. But the Party members gave nothing. Not out of greed, nor because of viciousness. They were just very afraid. ${ }^{36}$

\section{The Disappearance of an Author}

Answering questions at a reading of his stories in September 1937, Babel' said that he was writing about the transformation of the village, about the people in the collectivization campaign, in which he had "more or less" participated in 1929-1930 (Собрание сочинений, III, 392). As Babel' acknowledged, this was an event of the greatest importance in Russia since the October Revolution, and 
he clearly wished to penetrate the meaning of the contradictions and conflicts behind what was happening. Both "Gapa Guzhva" and "Kolyvushka" deal directly with the victims of collectivization. The force of the description is bound up with a monumental restraint that allows no emotional involvement, no partisan faltering in the relentless detachment of vision. No blame is apportioned. There is no justification. The final confrontation between Ivan and the hunchback chairman of the new collective farm becomes something of a religious procession, a half-hearted and hopeless popular uprising that resembles the Brueghelesque scenes of the crowd descending on the monastery in "The End of St. Нypatius" ("Конец Св.Ипатия"), not in pilgrimage, but to reclaim the place for the textile workers. ${ }^{37}$ One recalls also the ragged old men besieging the cemetery gates in "The End of the Old Folk's Home" ("Конец богадельни"). However, even if some of the villagers are prepared to speak up for him, Ivan, whose hair has turned white overnight, is forced to flee alone and is never seen again. The enormous snowy plains wedged tight against the jeweled skies and the stars falling down the well of the night make for a desperate vision of desolation and finality. In "Kolyvushka," Babel' described the village council meeting where the chairman seeks to win over the peasants with the promising consequences for the economy of the fundamental transformation of village life (the new collective farm "Awakening" will engage in dairy farming and market gardening, taking advantage of the profitable proximity of Kiev), but the enormous human price is only too apparent.

This time there was no diary, and no intermediary peripatetic narrator who could mediate the moral shock of what was happening. Not only was the scale of the mass deportations and forced starvation nationwide, but all was orchestrated by the state, efficiently and under strict ideological control. There was no room here for ambiguity or irony. How was it to be conveyed without compromising the writer's integrity?

An earlier story, "The SS Cow-Wheat" ("Иван-да-Марья"), had been ambivalent about the men who were sent to the Volga on grain procurement expeditions, and the narrator remains a fairly neutral observer (though does not fail to note drunkenness and 
anti-Semitism). Those were the years of War Communism, when the peasantry openly opposed the Bolsheviks, and the struggle to feed starving Petrograd required heroic efforts. Now, there was no space for neutrality, there could be no deviance from the Party line (even if it changed course), and if the job could only be done through force, this was justified by an ideology that rejected humanitarian principles as weak-kneed whimpering. If the narrator of the Velikaia krinitsa stories was to be an outsider, he could not be a detached observer. And yet, if he was a Party activist, how could he evoke empathy with the victims of unprecedented horror? In contrast to the Red Cavalry and Childhood stories, Babel' seems to have eschewed an I-narrator, erasing any authorial position and robbing the reader of any moral guidance in facing the harsh facts of collectivization. The regional Party officials and activists are portrayed as only too human, not as callous monsters. Ivashko, whom the village has given a rough time, cannot risk showing any familiarity to Gapa or the other villagers.

Положив на стол руки, Ивашко сидел перед мятой, обкусанной грудой бумаг. Кожа его возле висков сморщилась, зрачки больной кошки висели в глазницах. Над ними торчали розовые голые дуги. (Собрание сочинений, III, 151)

He was sitting in front of a pile of crumbled, tattered papers, his hands resting on the table. The skin on either side of his forehead was wrinkled, and in his eyes hung the pupils of an ailing cat. Above them bulged the arches of his bare pink eye sockets. (Complete Works, 646)

The Voronkov judge, who replaces him, is a legend in his time, and has been nicknamed "216 per cent" for his rigor in obtaining grain requisitions. He is depicted as a weary older man, chewing bread and onions and poring late at night over a copy of Pravda, instructions from the regional committee, and the bulletins of the Ministry of Agriculture department in charge of collectivization (Собрание сочинений, III, 157; Complete Works, 650). He has taken off his spectacles and is partly covering his eyes with the palm of his hand. Judgment is left to the reader, while the setting (in contrast to the tranquil, luscious scenery of the steppe in Virgin Soil 
Upturned) brings home the unrelenting effects of a brutal reality. Kolyvushka's family flees without waiting for their deportation into the inhospitable, icy desert outside the village,

Ветер мял снизу и стонал в этой пустыне, рассыпая голубые валы. Жестяное небо стояло за ними. Алмазная сеть, блестя, оплетала небо. (Собрание сочинений, III, 162)

The wind spiraled in this desert, pummeling and moaning, scattering its blue waves behind which a mesh of diamonds wound sparkling. (Complete Works, 655)

After Kolyvushka bangs his keys down on the table at the village council meeting, from which he is excluded as a kulak, he storms out, leaving the committee members alarmed about his intentions:

Ночь была дилова, тяжела, как горный цветной камень. Жилы застывших ручьев пролегали в ней; звезда спустилась в колодцы черных облаков. (Собрание сочинений, III, 163-64)

The night was lilac and heavy, like a bright mountain crystal. Veins of frozen rivulets lay across it. A star sank into a well of black clouds. (Complete Works, 656)

The world of Velikaia Krinitsa is stark, merciless, and uncompromising. There is no positive socialist hero here like Sholokhov's Davidov, and no guiding ideology framing the narrative (though, when pressed to name influences and allegiances among contemporary Soviet writers, Babel' said he approved of the direction Sholokhov was taking in neo-Tolstoyan realism [Собрание сочинениน̆, III, 396-98]). In fact, information is sparse and must be gleaned from the few words of dialog. No room, however, is left for ambiguity.

"Gapa Guzhva" (dated Spring 1930) appeared in Novyi mir in 1931, but "Kolyvushka" seems to have been unpublishable and was first published abroad in 1963; it first appeared in the Soviet Union in a remote central Asian journal in 1967. Other parts of Velikaia Krinitsa were announced for publication in Novyi mir in 1931-1932, but never appeared: these were "Adrian Morinets" ("Адриан Моринец”), “Ноnеу” (“Мед”), and “Spring” (“Весна”). A story "Sulak" ("Сулак"), set in 1928, which had been announced in 1932 
and published in 1937 in a collectivization movement magazine, might relate to the Velikaia krinitsa sequence, or it may belong to a long-standing project about the capture of anti-Bolshevik partisans in the Ukraine; at one point, someone felt the story needed updating, and the archival manuscript is given the title "The Spy" ("Шпион"), more in keeping with the paranoiac mood of the times. We cannot know what harrowing accounts the lost or planned chapters may have contained. It is also difficult to imagine how Babel' maintained his optimistic hope for a socialist future after what he had personally seen in Ukrainian collective farms in the Kiev region at the height of the collectivization campaign in 1930. Since openly siding with deported kulaks would have been considered treacherous and outsiders would have been identified with the authorities, it is hard to imagine how Babel' could maintain the stance of an observer. This was surely more difficult than in the First Horse Army, where Babel' seems to have acted as translator at interrogations of prisoners and taken on other tasks beyond that of military correspondent. Certainly, writers were expected to participate in the brigades of Party activists and not accompany them as mere tourists. ${ }^{38}$ Did Babel' record the painful scenes and still side with the Party activists? Or perhaps he reacted like Lev Kopelev, an enthusiastic Party activist sent to the Ukraine in the final grain collection of 1933:

I heard the children ... choking, coughing with screams. And I saw the looks of the men: frightened, pleading, hateful, dully impassive, extinguished with despair or flaring up with half-made daring ferocity. ... It was excruciating to see and hear all this. And even worse to take part in it. No, it was worse to be present without taking part than when you tried to persuade someone, to explain something... And I persuaded myself, explained to myself, I mustn't give in to debilitating pity. We were realizing historical necessity. We were performing our revolutionary duty. We were obtaining grain for the socialist fatherland. For the five-year plan. ${ }^{39}$

We believed, despite what we ourselves had seen, learned, experienced..$^{40}$

Or did Babel' intend, as Platonov did in The Foundation Pit (Котлован, written 1929-1930, but published in Russia only in 
1987), to imbue the utopian vision of socialism with sadness and despair $?^{41}$ In Platonov's fantastic allegory, Nastia dies at the end, and the hope which the shock workers who were conscripted to the collective farms had invested in the USSR is laid to rest. The triumph of collectivization in bringing mechanization and a new life was celebrated in propaganda films like Alexander Dovzhenko's Earth (Земля, 1930), or Vladimir Kirshon's play Bread (Хлеб, 1930), both of which emphasized the threat from dispossessed kulaks. I have already noted the fate of Eisenstein's Bezhin Meadow, which was banned in March 1937 for deviating from the correct ideological treatment of collectivization, although it too shows the kulaks' vengeance; in this case a father murders the son who denounced him for planning to wreck the collective farm. ${ }^{42}$ Hand in hand with the purges, the collectivization and industrialization campaigns were ruthlessly implemented in the name of Soviet power. Their success and benefits were officially sanctioned myths, and the only criticism permitted was that from the mouth of Stalin. However, apart from Sholokhov's Virgin Soil Upturned, which was serialized in Novyi mir just a few months after "Gapa Guzhva" appeared in that journal and which marked the official parameters for depiction of collectivization, ${ }^{43}$ the subject was generally taboo in fiction until after Stalin's death. Later, after reading (in samizdat) Vasily Grossman's Forever Flowing (Все mечеm, 1970), or Solzhenitsyn's Gulag Archipelago (Apxunerar ГУЛАГ, 1958-68; published abroad 1973), diehard believers like Lev Kopelev wrote in their memoirs of their disillusion, wondering how they could have been part of all this.

Babel' did not succeed in publishing other collectivization stories and the book he had promised in his self-defense at the public hearing at FOSP in 1930 did not materialize. Two stories, "Sulak" and "Oil" seem on the surface to describe a triumphant Bolshevik position on wiping out the vestiges of Ukrainian nationalist resistance, on the one hand, and celebrating Soviet achievements in the oil industry, on the other. Yet in "Sulak" the narrator, who appears to be on the side of the Bolsheviks and speaks as part of a hit team hunting down the fugitive, does not actually take an ideological position, while in "Oil" the boisterous woman writing 
about her life manages (in the first, uncensored publication of the story) to report, alongside her unflagging zeal for her work in the oil refining industry, mass arrests of specialists and overinflated production targets. The seething bustle in Moscow of a socialist society under construction is nevertheless exciting:
вся разрыта, в окопах, завалена трубами, кирпичами, трамвайные линии перепутаны, ворочают хоботом привезенные из-за границы машины, трамбуют, грохочут, пахнет смолой, дым идет, как над пожарищем....(Собрание сочинений, III, 134)
[Moscow] is all dug up and full of trenches, pipes and bricks everywhere, a tangle of tram lines, machines imported from abroad are banging, tumbling rumbling, swinging their cranes, there's the stench of pitch, and there's smoke everywhere, like at a wildfire... (Complete Works, 692)

The conclusion seems to be that the ideal of the revolution remains untarnished and the battle for it continues. Yet it is still a tale of individuals, of Zinaida, a hysterical woman in the office who gets pregnant by Max Solomonovich, a Jew who is only interested in her because she is a shiksa with Russian aristocratic origins, and of Claudia herself, who persuades her to have the baby and who speaks out fearlessly at a meeting to defend a colleague daring to protest the impossible demands of Party officials. Claudia is the principled idealist who refuses to have anything to do with Shabsovich when he is promoted and has access to privileges. It is a tale of dedication to an ideal and to hard work.

Babel', we know, was attracted to the Chekists, and the ending of "The Journey" (as I have suggested) could be read as a wishfulfillment of empowerment by the Jewish intellectual who had been liberated from Tsarist oppression. In "Froim Grach," the old gangster is killed in cold blood, and the agent sent down from Moscow understands nothing of old Odessa, which has been brought to an end. There is a voyeuristic fascination with what makes these men tick in Babel's interest as a writer in those who wielded the power of death. Babel' may in fact have been a habitual voyeur, if we are to judge by an early story later entitled "Through the Fanlight" (1915), the abortion scene in "Mama, Rimma, and Alla" 
(1916), and a draft of a Red Cavalry story describing a Red Army man having intercourse wth a woman dressed in a man's uniform in a hotel room, which Babel' thought would provide material for a social analysis of Russian sex (Собрание сочинений, II, 361). The editor of Novyi mir, V. P. Polonsky, who published the collectivization story "Gapa Guzhva" in 1931, recorded his impression from Babel"s reading of the story that he had described a village, as in Red Cavalry, full of "blood, tears, sperm" (“кровь, слезы, сперма"). ${ }^{44}$ Polonsky found he had to deal with a painstaking craftsman and a fellow traveler anxious about his reputation, who would not be persuaded to hand over manuscripts until he was satisfied with them. All this was explained, Polonsky noted in his diary, by Babel"s tendency to become fixated with the extreme, with the extraordinary and grotesque side of human nature:

Бабель работал не только в Конной, он работал в Чека. Его жадность к крови, к смерти, к убийствам, ко всему страшному, его почти садическая страсть к страданиям ограничида его материал. Он присутствовал при смертных казнях, он наблюдал расстрелы, он собрал огромный материал о жестокости революции. Слезы и кровь - вот его материал. Он не может работать на обычном материале, ему нужен особенный, острый, пряный, смертельный. Ведь вся Конармия такова. А все, что у него есть теперь, - это, вероятно, про Чека. Он и в Конармию пошел, чтобы собрать этот материал. А публиковать сейчас боится. ${ }^{45}$

Babel' worked not only in the First Horse Army, he worked in the Cheka. His thirst for blood, for death, for killings, for all that was terrifying, his almost sadistic passion for suffering limited his material. He was present at executions, he observed shootings, he collected an enormous amount of material on the cruelty of the revolution. Tears and blood, this is his material. He cannot work on ordinary material, he needs the peculiar, the sharp, the pungent, the deathly. But then all of Red Cavalry is like that. And everything that he has now is, no doubt, about the Cheka. He went into the First Horse Army, too, to collect this material. But he is afraid to publish it.

The voyeuristic interest in rape in "At Bat'ko Makhno's" (discussed in the previous chapter), prostitution ("Through the Fanlight"; 
"The Chinaman"; “Tale of a Hardworking Woman"), and murder ("Beresteczko"; "The Journey") betrays no subject position, and yet a humanizing vantage point is introduced into the everyday banality of life, exposing what is both grotesque and extraordinary in the human condition.

The play on historical and religious myth was to become muted in Babel's prose of the late twenties and thirties, when Babel' drew on his colorful metaphors and sensuous imagery more sparsely and thus more devastatingly in his search for a new style and form. He nevertheless remained aware of the effect of the detached view of individual fates in an overbearing historical reality, as we see in the fragment that has survived of the novella The Jewess, which draws a poignant picture of the final demise of the Jewish shtetl and the move of a Jewish Red Army officer's family to Moscow. Boris Ehrlich has none of the complexes of Liutov, and his self-assured integration into the Soviet military elite contrasts with the shoddy, broken lives of his relatives, former Jewish traders ruined by the Bolshevik Revolution. Nor does his confidence in the future dispel his widowed mother's anxieties - traveling in the comfortable modern railway carriage, she cannot help worrying that someone will have to pay for this luxury. And while she assumes her maternal position by the samovar when Boris's comrades-in-arms come to visit, the smell of Jewish cooking in their new communal apartment in Moscow is not well-received.

Babel', who knew the truth about Stalinism, confided in very few friends (among them Ehrenburg and Boris Suvarin in Paris). ${ }^{46}$ Possibly, we will never know how much of that truth he managed to tell in the stories that have been lost to us. What is clear is that the collectivization book was conceived of as a multi-voiced tale that would give the viewpoint of both activists and dispossessed, without giving away an authorial position. Such a book could not be published in Stalin's Russia. 


\section{Bibliography of Works by Babel' and Recommended Reading}

This bibliography of the works of Isaak Babel' attempts to present as complete a picture as possible of the surviving corpus of Babel's work. This is no easy task. At the time of his arrest in May 1939, Babel"s manuscripts were seized by the secret police and have not been recovered; Babel' was heard to say as he was led away, "They did not let me finish." A new collection of stories, New Stories (Новые Рассказы), about "heroes of our times," was planned for publication by the state-run publishing house Sovetskii pisatel' in a print run of 20,000 copies, and during the 1930s Soviet magazines had announced publication of stories we know only by their titles. How much Babel' had produced and stowed in his famous chest of the Miserly Knight we may never know. The conditions in which Babel' wrote and his own mischievous dealings with editors make any claim about the extent of his unpublished work speculative. Moreover, censorship, both during his life and after his death in the Soviet Union and elsewhere, resulted in the distortion or suppression of texts. Even after Babel"s posthumous rehabilitation in 1954, it cost Ehrenburg much effort to have a selected works published in 1957. An enlarged selected works appeared in 1966, as the clampdown on dissidents stepped up (Siniavsky was arrested in 1965). A slightly larger selection was published the same year in Kemerovo, instead of Odessa (as planned), because of fear that it would give the impression of an independent Odessa Jewish voice. All uncensored editions of Red Cavalry (that is, through 1931) were still on the list of banned books in the USSR in 1973. The repression of dissident and Jewish cultural activity and the reactionary atmosphere of the Brezhnev years made further publication seem 
unlikely in the USSR and Babel' entered a gray zone, relieved only by sporadic publication of material in Central Asian journals, far from Moscow's vigilant eyes. Perestroika eased some restrictions and new collections were published in Moscow starting in 1989, though there was some opposition on nationalist and ideological grounds; only at the end of the Soviet period did a two-volume collected works appear. This, like the following post-Soviet collections published in Russia, was based on the expurgated last collection of Babel"s stories to appear in his lifetime, in 1936, with restoration of some cuts. These collections generally organize the stories, apart from Red Cavalry and the Odessa stories, chronologically, though not always according to actual date of composition. The 2006 fourvolume edition, however, regroups the work thematically. The bibliography of Babel"s works that follows attempts to restore the corpus by reconstructing the cycles and books Babel' planned, thus giving a clearer idea of the development of his writing.

\section{First Publication of Works by Isaak Babel'}

\section{Early Prose (1913-1918)}

Babel" did not republish his early work, and in his "Autobiography" he presented a more politically correct literary career.

“Старый Шлойме”, Огни [Киев] 9 февраля 1913, 3-4.

“Три часа дня". Incomplete and undated MS in pre-revolutionary orthography. Edited version: Филологический сборник [Алма-Ата] 10 (1971): 46-47.

“Детство. У бабушки". Incomplete MS, dated Saratov, 12 December 1915. Published Литературное наследство 74 (1965): 483-88. Seе related Childhood stories in the section "История моей голубятни" below.

“Мама, Римма и Алла", Аетопись 11 (1916): 32-40.

“Элья Исаакович и Маргарита Прокофьевна", Аетопись 11 (1916): 41-44. Most republications give the title as "Илья Исаакович и Маргарита Прокофьевна".

“Шабос-нахаму (Из цикла Гершеле)”, Вечерняя звезда [Петроград], 16 марта 1918, 2-3. A Russian adaptation of the Yiddish folktale, "די מעשיה מיט שבת-נחמו", one of many oral anecdotes about the 
legendary Hershel Ostropoler, an eighteenth-century jester at the court of a Hasidic rebbe.

\section{2. Мои дистки}

Sketches under the pen-name "Bab-El'" in the Petrograd press, 19161917.

“Публичная библиотека”, Журнал журналов 48 (1916): 11-12.

“Девять", Журнал журналов 49 (1916): 7.

“Одесса", Журнал журналов 51 (1916): 4-5.

“Вдохновение”, Журнал журналов 7 (1917): 11-12.

“Мои листки: Рассказ И.Бабеля”, Журнал журналов 16 (1917): 11. An early version of "В щелочку", probably composed in 1915. This story was originally to appear in Gor'ky's Aemonucb in 1916 but was banned by the Tsarist censor.

“Дуду", Свободные мысли 2 (13 марта 1917). A publication of Журнал журналов after the February Revolution.

“Аистки об Одессе I”, Вечернял звезда 19 (6) марта 1918.

“Аистки об Одессе II”, Вечерняя звезда 21 (8) марта 1918.

\section{3. Дневник}

Sketches under the pen-name "Bab-El'" in the Petrograd press, 1918. The following dates are New Style, with Old Style in parenthesis.

“Первая помощь”, Новая жизнь 9 марта (24 февраля) 1918, 2.

“О лошадях", Новая жизнь 16 (3) марта 1918, 2. Signed "И.Б."

"Недоноски”, Новая жизнь 26 (13) марта 1918.

“Битые”, Новая жизнь 29 (16) марта 1918.

“Дворец материнства”, Новая жизнь 31 (18) марта 1918.

“Эвакуированные”, Новая жизнь 13 апреля 1918.

“Мозаика”, Новая жизнь 21 (5) апреля 1918.

“Заведеньице”, Новая жизнь 25 (12) апреля 1918, 1-2.

“О грузине, керенке и генеральской дочке: Нечто современное”, Новая жизнь 4 мая (21 апреля) 1918.

"Слепые", Новая жизнь 19 (6) мая 1918.

“Вечер”, Новая жизнь 21 (8) мая 1918.

"Петербургский дневник: Я задним стоял", Новая жизнь (Московское издание) 7 июня (25 мая) 1918. 
Bibliography of Works by Babel' and Recommended Reading

“Зверь молчит”, Новая жизнь 9 июня (27 мая) 1918.

“Финны”, Новая жизнь 11 июня (29 мая) 1918.

“Новый быт”, Новая жизнь 20 (7) июня 1918.

“Случай на Невском”, Новая жизнь 27 (14) июня 1918.

“Святейший патриарх", Новая жизнь 2 июля (19 июня) 1918.

“На станции: Набросок с натуры”, Эра 13 июля 1918. This sketch is similar in style to the previous pieces but describes an earlier incident during the First World War.

“На Дворцовой площади”, Жизнь искусства 11 ноября 1918. A sketch oif the first anniversarty of the Bolshevik coup.

“Концерт в Катериненштадте", Жизнь искусства 13 ноября 1918. A sketch about a German colony on the Volga that forms the background to the story "Иван-да-Марья".

\section{4. На поде чести}

Four stories published in the short-lived Odessa journal Лaвa in June 1920 under the heading "На поле чести." Babel"s introductory note explained that these were the beginning of his notes on war and were based on a book by Gaston Vidal, Figures et Anecdotes de la Grande Guerre (Paris, 1918). All but one of the stories ("Квакер") may be traced to Vidal's book.

“На поле чести", Лава 1 (1920): 10.

“Дезертир", Лава 1 (1920): 10-11.

“Семейство папаши Мареско", Лава 1 (1920): 11-20.

“Квакер", Аава 1 (1920): 12-13.

\section{5 Красньй кавалерист}

Articles by Babel' under the pseudonym K. Liutov for the First Red Cavalry frontline newspaper in 1920.

"Побольше таких Труновых", Красный кавалерист 13 августа 1920, 3. On the death of Trunov, described also in the Red Cavalry story "Эскадронный Трунов".

“Рыцари цивилизации”, Красный кавалерист 14 августа 1920, 2. Signed "K.Л."

“Героиня санитарка", Красный кавалерист 31 августа 1920, с. 3. Signed $\lambda$-в. Ascribed to Babel' by Stiv Levin.

“Экспедиция, подтянись”, Красный кавалерист 11 сентября 1920, 4. A letter addressed to the editor. 
Bibliography of Works by Babel' and Recommended Reading

“Недобитые убийцы”, Красный кавалерист 17 сентября 1920, 2.

“Ее день”, Красный кавалерист 19 сентября 1920, 2.

\section{6. Письма из Батума; Письма из Абхазии.}

Articles written in 1922 for the Tbilisi newspaper Зарл Востока as a special correspondent. A number of sketches appeared under Babel"s First Cavalry Army pseudonym, "K. Liutov." One unsigned piece "Столица Абхазии" has been attributed to Babel' by Usher Spektor, И. Бабель. Пробуждение (Тбилиси: Мерани, 1989), 407.

“В доме отдыха", Заря Востока 24 июня 1922.

"Камо и Шаумян: Письмо из Батума", Заря Востока 31 августа 1922.

“Столица Абхазии: Письма из Абхазии”, Заря Востока 6 сентября 1922. Unsigned.

"Мадресе и школа: Письма из Аджарии", Заря Востока 14 сентября 1922.

“Без родины: Письмо из Батума”, Заря Востока 14 сентября 1922.

“Гагры: Абхазские письма", Заря Востока 22 сентября 1922.

“Табак: Письма из Абхазии”, Заря Востока 29 октября 1922.

"В чакве”, Заря Востока 3 декабря 1922. Revised version: Известия Одесского губисполкома, губкома и губпрофсовета КП(б) Украины 25 марта 1923. Under the heading “Кавказский дневник."

"Ремонт и чистка: Абхазские письма", Заря Востока 14 декабря 1922.

"Паризот и Юлия", Известия Одесского губисполкома 17 марта 1924 (evening edition), signed "Баб-Эль". An account of ships returned to Russian ownership similar to that in "Камо и Шаумян."

\section{7. Конармия (in sequential order) (1920-1925)}

Most of the 34 stories included in the first edition of Конармия (1926) first appeared in Odessa and in Moscow in 1923-1924 under the heading "Из книги Конармия" and some were republished in Moscow journals and collections of Babel"s short stories in 1923-1926. The journal versions often vary from the text of the first edition published in 1926. Besides the stories included in the first edition, there were a few stories published in journals connected thematically with the cycle that were never included in the cycle by the author; evidence that a larger cycle may originally have been conceived is found in the drafts and plans published partially 
in Аитературное наследство 74 (1965) and in full in Аитературное обозрение 2 (1995): 49-66.

"Переход через Збруч", Правда 3 августа 1924, 4, with the subtitle “Из дневника"; republished Красная нива 3 (1925). Dated Novograd-Volynsk, 1 July 1920.

"Костел в Новограде", Известия Одесского губисполкома 18 февраля 1923; republished Красная нива 39 (1924).

"Письмо", Известия Одесского губисполкома 11 февраля 1923. Dated Novograd-Volynsk, June 1920. Republished: Леф 4 (августдекабрь 1923): 63-66.

“Начальник конзапаса", Һеф 4 (август-декабрь 1923): 69-70, under the title "Дьяков". Dated Belev, July 1920.

"Пан Аполек", Известия Одесского губисполкома [январь 1923], dated Novograd-Volynsky, June 1920. Republished: Красная новь 7 (декабрь 1923).

“Солнце Италии”, Красная новь 3 (апрель-мая 1924): 8-10, under the title "Сидоров". Dated Novograd, July 1920.

"Гедали", Известия Одесского губисполкома 29 июня 1924. Dated Zhitomir, June 1920. Republished: Красная новь 4 (июнь-июль 1924): 13-15.

"Мой первый гусь", Известия Одесского губисполкома 4 мая 1923. Republished: Лeф 1 (1924). Dated July 1920.

“Рабби", Красная новь 1 (январь-февраль 1924): 68-69. Also Известия Одесского губисполкома 9 марта 1924. Dated June 1920.

“Путь в Броды”, Известия Одесского губисполкома 17 июня 1923. Republished Прожектор 21 (1923). Dated Brody, August 1920.

“Учение о тачанке", Известия Одесского губисполкома 23 февраля 1923. Republished Прожектор 21 (1923).

"Смерть Долгушова", Известия Одесского губисполкома 1 мая 1923. Dated Brody, August 1920. Republished in Moscow: Огонек, 9 мая 1923; Леф 4 (август-декабрь 1923): 66-68.

"Комбриг два", Леф 4 (август-декабрь 1923): 70-72 under the heading "Колесников". Dated Brody, August 1920.

"Сашка Христос", Известия Одесского губисполкома 10 февраля 1924; Красная новь 1 (январь-февраль 1924): 64-67.

“Жизнеописание Павдиченки, Матвея Родионыча", Шквал [Одесса] 8 (декабрь 1924). Republished: 30 дней 1 (1925). 
“Кладбище в Козине”, Известия Одесского губисполкома 23 февраля 1923. Republished: Прожектор 21 (1923).

"Прищепа", Известия Одесского губисполкома 17 июня 1923; Леф 4 (август-декабрь 1923): 72. Dated Demidowka, July 1920.

“История одной иошади”, Известия Одесского губисполкома 13 апреля 1923 under the title "Тимошенко и Мельников." Republished: Красная новь 3 (апрель-май 1924): 10-13. Dated June 1920.

"Конкин", Известия Одесского губисполкома 6 апреля 1924. Republished: Красная новь 3 (апрель-май 1924): 21-23. Dated Dubno, August 1920.

"Берестечко", Известия Одесского губисполкома 1 марта 1924. Republished: Красная новь 3 (апрель-май 1924): 19-21. Dated Berestechko, 1920.

“Соль", Известия Одесского губисполкома 25 ноября 1923; Леф 4 (1923): 73-75.

"Вечер", Красная новь 3 (апрель 1925): 127-128 under the title "Галин". Republished: Шквал 15 (1925). Dated Kovel, 1920.

"Афонька Бида", Красная новь 1 (январь-февраль 1924): 60-64; Известия Одесского губисполкома 1 марта 1924. Dated Beresteczko, August 1920.

“У святого Валента", Красная новь 3 (апрель-май 1924): 13-16. Dated Beresteczko, August 1920.

“Эскадронный Трунов”, Красная новь 2 (февраль 1925): 3-8; Шквал 13 (март 1925).

“Иваны”, Русский современник 1 (1924): 151-156.

"Прододжение истории одной иошади", Известия Одесского губисполкома 13 апреля 1923 under the title "Тимошенко и Мельников". Republished: Красная новь 3 (апрель-май 1924): 2829. Dated Galicia, September 1920.

“Вдова", Известия Одесского губисполкома 15 июля 1923, under the title "Шевелев". Republished: Красная новь 3 (апрель-май 1924). Dated Galicia, August 1920.

“Замостье”, Красная новь 3 (апрель-май 1924): 26-28. Dated Sokal', September 1920.

"Измена", Известия Одесского губисполкома 20 марта 1923. Republished: Красная газета 13.3.1926; Пролетарий [Харьков] (1926). Dated 1920. 
Bibliography of Works by Babel' and Recommended Reading

“Чесники", Красная новъ 3 (апрель-май 1924): 23-26.

"После боя", Прожектор 20 (октябрь 1924); Известия Одесского губисполкома 2 ноября 1924. Dated Galicia, September 1920.

"Песня", Красная новь 3 (апрель 1925): 125-127, under the title “Вечер". Dated Sokal', 8.20.

“Сын рабби", Красная новь 1 (январь-февраль 1924): 69-71; Известия Одесского губисполкома 9 марта 1924. Dated Berdichev, September 1920.

\section{Other Red Cavalry stories}

"Грищук", Известия Одесского губисполкома 23 февраля 1923. Related to "Учение о тачанке", alongside which it was published; omitted from all editions of Конармия.

“Их было девять", Новый журнал (Нью Йорк) 95 (июнь 1969): 16-20; republished with a fragment of an earlier version "Их было десять" in И.Бабель. Петербург 1918. Ann Arbor: Ardis, 1989, 246-47; and in Огонек 4 (1989). Related to the shooting of prisoners incident in "Эскадронный Трунов" and dated 1923 in the MS.

“Старательная женщина”, Перевал: Альманах 6 (1928): 188-190.

“У батьки нашего Махно”, Красная новь 4 (1924): 12-13.

“Аргамак”, Новый мир 3 (1932): 125-127. Dated 1924-1930. Added to the cycle in the 1933 edition as the new conclusion of Конармия.

"Поцелуй", Красная новь 7 (1937): 49-51. Sometimes regarded as an alternative ending to Конармия, but never included in the cycle by Babel".

\section{Odessa Stories (in sequential order) (1920-1932)}

In Babel"s lifetime, only four stories were grouped together in this cycle in collections of his work, and this practice continued until the end of the Soviet period, but also in some post-Soviet Russian editions. An unsigned manuscript of a story about Odessa in the Civil War years, not directly linked with the rest of the cycle, entitled "Кольцо Эсфири: Рассказ" was published by Antonina Pirozhkova, who ascribes it, on the evidence of testimony, to Babel', in Cлово/Word [New York] 35-36 (2002): 3-5; and in Bопросы хитературы 2 (2003): 283-286. The original manuscript, given by Babel' to a typist in the editorial offices of the Odessa journal Mopя 1 , is not extant and so it is not possible to conclusively authenticate the text, which probably dates from around 1923. 
“Король", Моряк [Одесса], 23 июня 1921. Republished with revisions: Известия Одесского губисполкома 14-16 мая 1923; Леф 4 (август-декабрь 1923): 76-80.

“Как это делалось в Одессе”, Известия Одесского губисполкома 5 мая 1923. Republished: Леф 4 (август-декабрь 1923): 81-88.

"Справедливость в скобках", На помощь! [Одесса], 15 августа 1921. This was the only issue of a charity newspaper.

“Любка Казак", Красная новъ 5 (август-сентябрь 1924): 3-7; Шквал 1 (сентябрь 1924): 4-6.

“Отец”, Красная новь 5 (август-сентябрь 1924): 36-42.

“Закат", Аитературная Россия 20 ноября 1964, 22-23. MS dating from 1923-1925 in the collection of Babel"s son, M. V. Ivanov, on the headed notepaper of the firm of E.I. Babel'. Related to the play of the same name. The last lines of the MS are missing.

“Фроим Грач”, Воздуиные Пути [Нью Йорк] 3 (1963): 29-34. In 1933, Gor'ky recommended this story, probably composed in the late twenties, for publication in $\Gamma o \partial X V I$, but it remained unpublished in Babel's lifetime. First Soviet publication, 3намя 8 (1964).

“Конец богадельни”, 30 дней 1 (1932): 21-25. Dated 1920-1929.

“Карл-Янкель", Звезда 7 (1931): 55-60; reprinted: Последние новости [Paris] 3929 (декабрь 1931): 3-4.

\section{0. Петербург 1918}

Stories written in 1919-1923 about revolutionary Petrograd, evidently a project that evolved from the journalism of 1918.

“Вечер у императрицы (Из петербургского дневника)", first published as "В гостях у императрицы" in a one-day newspaper Раненный красноармееи signed "Liutov", Odessa, March 1921; republished Силуәты [Одесса] 1 (декабрь 1922): 7. An early version of "Дорога".

“Ходя (Из книги Петербург 1918)", Силуэты [Одесса] 6-7 (1923): 5. Republished in Moscow, Перевал 6 (1928).

\section{Oфорть (1921-1924) and other stories of the twenties}

"Иисусов грех", Нахлеб 29 августа 1921. One-day charity newspaper in aid of famine-victims, Odessa. Republished in Moscow, Kpyz 3 (1924).

“Сказка про бабу", Силуәты [Одесса] 8-9 (1923): 5-6. A variant of "Иисусов грех". 
“Баграт Оглы и глаза его быка”, Силуэты [Одесса] 12 (1923). Under the heading: "Из книги Офорты". Republished in Moscow, Краснал новь 4 (1924): 11-12.

"В щелочку", Силуэты [Одесса] 12 (1923): 5. Under the heading: Из книги Офорты. Another version of "Мои листки: Рассказ" in the “Мои листки" series. Revised version: Перевал 6 (1928).

“Аиния и цвет”, Красная новь 7 (декабрь 1923): 108-110 with the subtitle: "Истинное происшествие". Published under the heading: "Миниатюры", together with "Пан Аполек", a Red Cavalry story that deals with a similar artistic theme.

“Ты проморгал, капитан!”, Известия Одесского губисполкома 9 февраля 1924 (evening edition), signed “Баб-Эль”. Another version, dated Odessa, 27 January 1924, the day of Lenin's funeral, appeared in the Moscow journal Красная нива 39 (сентябрь 1924): 937.

“Конец святого Ипатия (Из дневника)”, Правда 3 августа 1924, 4. Dated Kostroma, 20 October 1923. Slightly revised version: 30 дней 5 (1925).

“Иван-да-Марья", 30 дней 4 (1932): 13-17. Dated 1920-1928. Originally announced at the end of 1931 for publication in Hobsiŭ мup. Connected with Babel"s experiences in 1918 on grainrequisition expeditions.

“Мой первый гонорар". Published posthumously, Воздушные пути [Нью Йорк] 3 (1963): 35-44. Dated in the manuscript 1922-1928. A later version, "Справка", first published in English translation, International Literature [Moscow], 9 (1937): 86-88; posthumously in И. Бабель. Избранное. Кемерово: Кемеровское книжное издательство, 1966, 320-323. Based on a story told by Petr Storitsyn (Kogan), whom Babel' knew in Petrograd in 1919, and set in Tbilisi, where Babel' published his Caucasian sketches in 1922.

\section{2. История моей голубятни (in sequential order)}

This was the title of Babel's planned book of related Childhood stories. The first story that is thematically connected appears in a manuscript, "Детство. У бабушки", dated 1915 (see Early Prose above). The last story published in the series was "Ди Грассо" in 1937, but sequentially it precedes "Гюи де Мопассан" and "Дорога", both begun in the early twenties. "Дорога" brings the story of the Odessa youth up to the Bolshevik Revolution and the Civil War.

“История моей голубятни”, Красная новь 4 (1925): 33-40. Dedicated to Gor'ky and accompanied by an editorial footnote indicating that 
this was the beginning of an autobiographical novella (nовесть). Babel" had intended the story to appear together with "Первая июбовь". Republished in Шквал 17 (май 1925); Красная газета 18, 19, 20.5.1925.

“Первая дюбовь”, Альманах Красная новь 1 (Москва-Денинград, 1925): 62-69. Also in Шквал 18 (1925), under the heading: "История моей голубятни"; Красная газета 23, 25.6.1925.

“В подвале", Новый мир 10 (1931): 21-25, under the heading: Из книги История моей голубятни. Dated 1929.

“Пробуждение", Молодая гвардия 17-18 (сентябрь 1931): 13-16. Under the heading: "Из книги История моей голубятни". Dated in later editions 1930 .

“Ди Грассо”, Огонек 23 (20 августа 1937): 1.

“Гюи де Мопассан", 30 дней 6 (1932): 34, 36-38. Dated 1920-1922.

“Дорога", 30 дней 3 (1932): 41-43. Dated 1920-1930. A reworked version of "Вечер у императрицы".

13. На биржу труда (1927)

“Большие пожары”, Огонек 9 (1927): 8-9. Chapter 9 of a collective novel by twenty-five authors.

\section{Paris Stories (1927-1933)}

Babel"s stay in Paris in 1927-1928 and 1932, and a brief visit in 1935 provided much material for sketches and stories. In 1927 Новый мир announced a story called "Мария Антуанетта", which may be connected with a project Babel' was working on in the Bibliothèque Nationale on the subject of the French Revolution, which he mentioned in correspondence from Paris to Anna Slonim.

“У дица Данте (Из парижских рассказов)”, 30 дней 3 (1934): 40-44.

“Суд (Из записной книжки)”, Огонек 23 (1938): 8. See also the journalistic sketch "Путешествие во Францию".

15. Еврейка (1927-?)

"Еврейка", fragment of a larger prose work on which Babel' worked from about 1927 onwards. Undated MS published in the New York emigré Новый журнал 95 (June 1969): 5-16. First Soviet publication: Год за годом: Аитературный ежегодник 4 (1988): 295-306.

\section{6. Великая Криници аnd other stories of the thirties}

Babel' was planning a book of stories under the title Великая Криница about the collectivization he had witnessed in the Kiev region. 
Judging from the two chapters that have appeared in print, there is little chance this book would have been publishable in the conditions of Stalinist Russia. Other parts of this book about collectivization were announced for publication in Новый мир in 1931-1932, but never appeared ("Адриан Моринец", “Мед", “Весна"), as well as "У троицы", which Babel"s friends Gekht and Ehrenburg recall Babel' reading to them. Other lost works of the thirties include a novella (повесть) about a former gangster on collectivized farms and in heavy industry "Коля Топуз" and stories about KabardinoBalkariia, whose charismatic leader was purged by Stalin.

"Гапа Гужва", Новый мир 10 (1931): 17-20. Under the heading: "Первая глава из книги Великая Криниц̧а". Dated Spring 1930.

"Колывушка", MS of another chapter from Великая Криница, dated Spring 1930, probably composed 1931-1935, first published in the New York émigré journal, Воздушныле пути 3 (1963): 45-51. First Soviet publication: Звезда Востока 3 (1967).

“Нефть”, Вечерняя Москва, 14 февраля 1934. A story about an oil production plant. Later versions are censored.

"Сулак", Молодой колхозник 6 (1937): 14. This story, set in 1928, about the capture of a fugitive Ukrainian nationalist may conceivably be connected to the Collectivization book. An alternative title in an archival typescript is "Шпион".

\section{7. СССР на стройке / USSR in Construction (1936-1937)}

This Soviet propaganda magazine appeared in different languages. Babel" seems to have collaborated on it with a former Odessa friend, then married to the secret police chief Ezhov. U. Spektor also attributes to Babel' a contribution to the issue on the Donbass, СССР на стройке 6 (1939); presumably, Babel"s name was dropped because of his arrest.

“Колхозы на Киевщине”, СССР на стройке 3 (1936). Layout and text by Babel". An issue devoted to collectivization in the Kiev district.

"М.Горький”, СССР на стройке 4 (1937). Special issue dedicated to Gor'ky, planned and edited with a foreword by Babel".

\section{Plays}

Babel"s career in the theater was brief and none too successful. In the 1930s, however, Babel' was working on a Gogolian satire about a town that went mad. 
“Закат", Новый мир 2 (1928): 5-35. In book form with some distortions: Закат. Москва: Артель писателей "Круг", 1928. Premiered at the Baku Workers' Theater, 23 October 1927, directed by V. F. Fedorov. Two days later the play opened in Odessa under the direction of A. Gripich in the Odessa Theatre of Russian Drama; in December it was also produced at the Odessa Theatre of Ukrainian Drama. From February through December 1928 the play was included in the repertoire of the Second Moscow Arts Theater, but proved unsuccessful and was dropped.

"Мария", Театр и драматургия 3 (1935). Repressed while in rehearsal at the Moscow Jewish and Vakhtangov theaters. Part of a Civil War trilogy, of which the second part was to be called Чекисть.

“Мама, Римма и Алла", undated MS of first and beginning of second scene of unpublished dramatization of the short story of the same name.

\section{Filmography}

Babel"s film work was undertaken mainly to pay off debts, but some of the projects Babel' was involved in apparently never materialized or were completed by others. In 1925, for example, Furmanov asked Babel' to help with a film version of his novel, Chapaev, but his collaboration is uncertain. Babel' was apparently not involved in Sergei Eisenstein's screen adaptation with Grigori Aleksandrov and Yakov Bliokh of Конармия in December 1924 as part of a film about the Civil War to be shot at the Moscow Sevzapkino studios. Mentioned in the film press in January-February 1925, work on the screenplay was interrupted in March 1925 for lack of budget. In 1927, motifs from the film were transferred to an unrealized sequel to Eisenstein's Октябрь. A French company was interested in a film version of Конармия in 1933, but nothing seems to have come of it. In 1933, Babel' negotiated with Mosfilm for a script based on Конармия, but abandoned the idea.When Eisenstein returned to the USSR in 1932, Babel' helped him get hack-work until Malraux proposed a movie version of La Condition humaine in June 1934. Babel' had a contract with the Mezhrabprom studio to work as an expert advisor for the film version, to be directed by Albert Gendelstein. After the First Soviet Writers' Congress, Eisenstein traveled to the Crimea with Malraux and Babel' to work on the script but the film was not made. In 1937 Babel' conceived a film, or drama, about the Civil War hero Kotovskii, whom he knew. The film was made in 1942, based on a script by Alexei Kapler, directed by Alexander Fainzimmer, with music by Prokofiev. As in Babel"s work on a movie version of Gor'ky's trilogy, 
he was not credited for his participation in projects released after his arrest.

Coль. Scenario for a film directed by P. Chardynin at the Odessa studios of the Ukrainian state film Company (VUFKU), July 1925. Based on the Red Cavalry story of the same name. Released 1925 on the Ukrainian screen as part of the short-lived cinematic magazine Маховик.

Еврейское счастье. Adapted from the Menakhem Mendel stories of Sholom Aleichem by G. Gricher, B. Leonidov and I. Temeromo, reworked by A. Granovsky; directed by G. Gricher. Camera: Eduard Tisse. Starring the famous Yiddish actor Mikhoels and filmed on location with members of a Jewish troupe. Babel' supplied the titles, which stirred up a controversy in the press. Released 1925. Later, the titles were changed to Yiddish and English in a New York release.

Блуждающие звезды. Scenario adapted from Sholom Aleichem's novel of the same name. Directed by G. Gricher. Released 1927. Published Москва: Кинопечать, 1926; prose narrative excerpts appeared in Шквал 3 (1925) and 30 дней 1 (1926): 52-59; Советский экран 7 (1926).

Беня Крик. Scenario based on the Odessa stories. Directed by V. Vilner in 1926 in VUFKU's Odessa studios and put on general release early 1927. Published Красная новь 6 (1926): 3-42; prose narrative excerpts appeared in Шквал 22-27 (1926) in six parts; in book form, Беня Крик: Киноповесть. Москва: Артель писателей “Круг”, 1927.

Китайская мельнициа. Film comedy written by Babel' in 1927, based on a sketch in Комсомольская правда. Directed by L. Levshin. Released 1928. MS subtitled "Пробная мобилизация" published by Nathalie Babel, Ulbandus Review 1, 2 (1978): 99-156.

Джими Хигинс. Adaptation of Upton Sinclair's novel Jimmy Higgins, co-scripted with G. Tasin. Directed by G. Tasin, 1928.

Пьиика. Screen adaptation of Maupassant's "Boule de Suif," VUFKU studios, 1930. Babel' received an advance for the scripts, but decided he was more interested in investigating collectivization in the Kiev region and apparently did not complete the assignment. The film was written and produced by Mikhail Romm in 1934.

Documentary on the Dnieper construction project, scripted by Babel' in 1930. 
Азе $\oint$. During his stay in France in 1932 Babel' was commissioned to script a film on the infamous double-agent Y. F. Azef. Babel' wrote two scenes together with Olga Eliseevna Kolbasina, who had known Azef, but the project was abandoned, probably because someone offered the film company a completed script. However, in 1934 Babel' was still working on a film called Азеф in the Soviet Union.

Дума про Опанаса. Screen adaptation of Bagritsky's ballad of the same name. Babel' was commissioned to write the script by Ukrainfil'm studios in Kiev in 1934 as a posthumous tribute to the poet. Babel"s work was apparently interrupted by editorial assignments for Gor'ky.

Летчики. Babel' participated in making this film in 1934-1935, rewriting the original script about a flying school with the stipulation that his name should not appear in the credits, as he did not expect the film to be a success. To the amusement of Babel' and those in the know the film turned out to be a hit. Directed by Iu. Raizman, Mosfil'm, 1935.

Odecca. Script for a documentary film about the city by Jean Lods, 1936.

Бежин луг (Mosfil'm, 1935-37). Babel' and Eisenstein jointly reworked Rzhevsky's original script. Babel' joined the set on location in Yalta, but the second version got Eisenstein into further political trouble and he was forced to recant. Scenario published in C. Эйзенштейн, Избранные произведения. Том 6. Москва: Искусство, 1971, 129152. The film was apparently destroyed during German bombing of Moscow during World War Two, but in the seventies a short version was recreated from stills and set to music by Sergei Prokofiev.

Как закалялась сталь. Screen adaptation of Nikolai Ostrovsky's novel of the same name. Excerpts published Аитературнал газета, 30 октября 1938. Revised version: Красноармееи 9-10 (1938): 40-41 and 12 (1938): 16-17. Babel' worked on the script with Julia Sol'ntseva. The film was to be directed by B. Barnet, but was actually made in 1942 by M. Donskoi, who is credited as a script writer.

Мои университеты. Screen adaptation of part of Gor'ky's famous autobiographical trilogy. Script by I. Babel' and I. Gruzdeva. Directed by M. Donskoi, Soiuzdetfil'm, 1939. As a result of Babel"s arrest, the scenarists were not credited when the film came out in 1940. 
Старая площадь, 4. Sound film about the building of an airship USSR 1. MS dated Leningrad 20 April 1939 in the archives of Gosfil'mofond. Published, Искусство кино 5 (1961): 59-78. Babel' worked on this film for Soiuzdetfil'm together with V. Kreps and apparently completed it hurriedly.

\section{Translation work}

Like Babel"s work on filmscripts, translation was initially a means to get the necessary funds to pay off debts, including paying back advances on stories not delivered, and to support his family abroad. However, despite the disclaimers he issued, there is little doubt that his work on translations from Sholom Aleichem was a labor of love, as were his translations from Maupassant, the short story writer he most resembles and after whom Babel' entitled his short story about translating and the secret of style, "Guy de Maupassant." (For Babel"s movie adaptation of Sholom Aleichem, Блуждающие звезды, see filmscripts above.) In 1936, Babel' was commissioned by the Academia publishing house to edit a jubilee edition of Sholom Aleichem, to appear in 1939. In the second half of the thirties, Babel' was translating Sholom Aleichem stories that had not appeared in Russian, as well as works by Mendel MoikherSforim, but no trace has been left of these translations. In 1935, Babel' translated a story from Yiddish by Binyomin Rifkind, which was subsequently read on Soviet radio.

Guy de Maupassant, Собрание сочинений. Под ред. И.Э.Бабеля. Москва-Ленинрад, 1926-27. Three volumes. The translations of "Idylle," "L'Aveu," and "Le mal d'André" are by Babel'. They are republished in Е.Погорельская, "И.Э.Бабель-редактор и переводчик Ги де Мопассана (материалы к творческой биографии писателя)." Вопросы хитературы 4 (2005): 338-351.

Sholom Aleichem, Избранные произведения. Под ред. И.Э. Бабеля. Москва-Денинград, 1926-27. Two volumes. Translated by S. Gekht.

Dovid Bergelson, “Джиро-Джиро”. Trans. I. E. Babel'. Красная новь 1 (1936). Reprinted in Д.Бергельсон, Рассказы. Москва: Журнально-газетное объединение, 1936 (Библиотека “Огонек" № 42). Republished (with the author's name given as translator, instead of Babel') in Д.Бергельсон, Избранные произведения. Москва: Дер Эмес, 1947. This translation seems to have been revised by Bergelson. Executed in 1952, Bergelson was rehabilitated after the death of Stalin and the story was reprinted in the first posthumous edition of his work, Д.Бергельсон, Избранное. Москва: Государственное издательство художественной дитературы, 1957, 296-310. 


\section{Essays, Memoirs and Prefaces}

Not included are letters to the press and inclusion in collective signatures, as in the 1925 petition to the Central Committee from fellow travelers for relief from attacks by Marxist critics, or denunciations of enemies of the state, such as "Дожь, предательство, смердяковщина". Аитературная газета, 26 января 1937. Collective signature of such denunciations was not always voluntary.

"Автобиография", in Писатехи: Автобиографии и портреть современных прозаиков. Под ред. В. Аидина. Москва: Н.А.Столияр, 1926, 27-29. Dated Sergiev Posad, November 1924. MS of 1932 version published in И. Бабель, Детство и другие рассказы. Иерусалим: Алия, 1979, 7-8.

“В Одессе каждый юноша...". Preface to an unrealized anthology of Odessa writers, Семь молодых одесситов (1923). First published Аитературная газета 1 января 1962, 3.

“Стихи Багрицкого полны ритмом большевизма”, Аитературная газета 18 февраля 1934, 1. A posthumous tribute to Bagritsky co-authored with fellow Odessites Valentin Kataev, Olesha, Il'f and Petrov.

“Багрицкий”. In Эдуард Багрицякий: Альманах. Под ред. В. Нарбута. Москва: Советский писатель, 1936. 160-61.

“Путешествие во Францию”, Пионер 3 (1937): 8-17. Notes on Babel"s visit to Paris in 1935.

"Начало", Год XXI (1938): 79-81. A memoir of Babel"s meeting with Gor'ky in 1916, based on an interview which Babel" gave to S. Tregub, "Учитель: Беседа с тов. И.Бабелем", Комсомольская правда 27 июля 1936, 3. A different version appeared in Аитературная газета 18 июня 1937, 3; also under the title "Из воспоминаний", Правда 18 июня 1937, 3.

“М.Горький”: see СССР на стройке above.

“Памяти А.Г. Малышкина", Известия 4 августа 1938, 4. Also published as "Прекрасный товарищ”, Аитературная газета 5 августа 1938, 2. A tribute to the author of Fall of Dair, signed by Babel' and thirty others.

"Литературные мечтания", Аитературная газета 31 декабря 1938, 5. Brief contribution to a page of hopes for the new year by Soviet writers. Babel"s wish is for a new edition of Lev Tolstoi. 
Foreword to the Odessa actor and musician Leonid Utesov's Записки актера, written 1939 but unpublished because of Babel"s arrest. It appeared as a preface to pre-publication excerpts of Utesov's reminiscences, "Моя Одесса," Аитературная Россия 21 августа 1964, 16; republished, Москва 9 (1964): 120. Reprinted as an afterword to Leonid Utesov, Моя Одесса. Одесса: OKFA, 1995.

\section{Public addresses and interviews}

“И.Э.Бабель о себе”, Вечерний Киев 31 марта 1927. Interview on the occasion of Babel"s public readings of the play 3aкam.

“И.Э.Бабель о новой картине Эйзенштейна: Выступление в Колонном зале Киевского Института народного хозяйства", Вечерний Киев 31 марта 1927. Babel"'s remarks on Eisenstein's The General Line.

In Spring 1927, Babel' gave a very guarded interview to Известия Одесского губисполкома.

Speech made by Babel' in his defense at a meeting of the secretariat of the writers' organization FOSP, Moscow, 13 July 1930. Transcript published, Памир [Душанбе] 6 (1974): 86-87.

Discussion with young writers in which Babel' talked about his story "Гюи де Мопассан" and promised to read the collectivization stories: Ольник, "Писатель И.Бабель в Смене", Смена 17-18 (1932): 25. Another account by the same author, "Я рад закрепить нашу дружбу-Бабель у комсомольцев", Аитературная газета 5 сентября 1932, 3.

"Soirée antifasciste: Allemagne, Perse, Chine, URSS vues par des écrivains révolutionnaires". Meeting held by the Association des Écrivains et Artistes Révolutionnaires, Paris, 16 June 1933. Speakers included Babel', Lev Nikulin, Egon Erwin Kisch, Louis Aragon, and Paul Vaillant-Couturier.

"40-ème annivérsaire de la vie littéraire de Maxime Gorki." Meeting held by the Association des Écrivains et Artistes Révolutionnaires, Paris, first half of 1933. Speakers included Babel', Jean-Richard Bloc, and Paul Vaillant-Couturier.

"На западе", Вечерняя Москва 16 сентября 1933. Babel"s impressions of his 1932-1933 visit to France and Italy, based on a talk given in Moscow, 11 September 1933. Excerpts from the transcript of the talk published by S. Povartsov in Bопросы литературы 4 (1974): 244-248; 4 (1979): 163-65. 
"Глазами писателя: Бабель о заграничной поездке", Аитературный Аенинград 26 сентября 1933. A further account of Babel"s trip abroad.

Public reading of Мария, 1934. Reported in Е.Пельсон, "Новая пьеса Бабеля: На авторской читке в Литературном музее”, Литературная газета 4 марта 1934, 4.

“Работа над рассказом: Из беседы с начинающими писателями”, Смена 6 (1934): 14.

Address at the First Soviet Writers' Congress, 1934. Published as И.Э.Бабель, “Речь на Первом всесоюзном съезде советских писателей, 23.8.1934." In Первый всесоюзный съезд советских писателей: Стенографический отчет. Ред. И.Аупполь, и др. Москва: Государственное издательство художественной литературы, 1934, 278-280. Reprinted Москва: Советский писатель, 1990. Edited version: “Содействовать победе бодьшевистского вкуса", Аитературная газета 24 августа 1934. A different version is "Пошлость-вот наш враг", Правда 25 августа 1934, 4. Later publications are censored.

Address to youth parade on Red Square, 1 September 1934. Published in "Музыка лозунгов: Писатели на площади”, Комсомольская правда 2 сентября 1934, 2.

Two-hour talk in the House of Soviet Writers, Moscow, 26 April 1935 on his contribution of stories about Kabardino-Balkariia to Gor'ky's planned anthology devoted to the second Five-Year Plan. Reported in Я.Э., “Встреча с Бабелем ", Литературнал газета 5 May 1935, 6.

Speech at a memorial meeting for the late Eduard Bagritsky, House of Soviet Writers, Moscow, 16 February 1935. Published in Эдyapd Багрицкий: Воспоминания современников. Под ред. А.Г.Багрицкой. Москва: Советский писатель, 1973, 400-01. Differs slightly from the memoir listed above.

Address to the Congress in Defense of Culture, Paris, summer 1935. Babel' and Pasternak, not included originally in the Soviet delegation, arrived late and delivered impromptu speeches, summarized by Ehrenburg and Savich in their memoirs. On his return to Moscow, Babel' attended a public debriefing on the congress, reported by Del'man, “Широким фронтом против фашизма: Товарищи И.Бабель, В.Киршон и К.Аупполь о Конгрессе защиты культуры", Аитературная газета 15 августа 
1935. See also Ehrenburg's report from the congress "Письмо с конгресса, 5: Последнее заседание." Известия 27 июня 1935, 2; and Pour la défense de la culture: Les textes du congrès international des écrivains, Paris, juin 1935. Ed. Sandra Teroni and Wolfgang Klein (Dijon: Editions universitaires de Dijon, 2005). The text of Babel"s extemporized address to the congress has not been preserved.

Speech at a conference of young writers in the Donbass, 1935, reported in Социалистический Донбасс 5 декабря 1935.

Speech on the centenary of the birth of the Yiddish writer Mendel Mocher-Sforim at a commemorative meeting, Moscow 1936. Reported by И.Эйдельман, “Менделе Мохер-Сфорим: На торжественном заседании в Доме союзов", Аитературная газета 5 марта 1936, 6.

Speech on the tenth anniversary of the death of Dmitri Furmanov, 5 March 1936. Partly published in "О Фурманове: Строгость и страсть писателя", Москва 4 (1963): 219-22.

Speech at the All-Moscow assembly of writers against "formalism" in art, 26 March 1936. Expurgated version, “О работниках новой культуры", Аитературная газета, 31 марта 1936, 1. Edited stenographic version published by I. V. Litvinenko in Встречu с прошлым , 2. Revised edition. Москва: Советская Россия, 1985, 209-13.

"Прощанье с Ильфом: Гражданская панихида", Литературная газета 20 апреля 1937, 5. Report of speeches of Babel' and others at Il'f's funeral.

Public reading of "Ди Грассо", "Справка", and other stories at the Soviet Writers' Union, 28 September 1937. Edited excerpts of a transcript of Babel"s remarks published as "О творческом пути писателя", Наш современник 4 (1964): 96-100. Further excerpts cited by С.Поварцов in Bonросы хитературь 4 (1979): 165-67.

Address to a working conference of young writers from the national republics, 30 December 1938. Unpublished transcript in IMLI f. 43, opis' 1, no. 944/2b, 33.

\section{Diary}

Babel"s 1920 Diary, written during the Soviet-Polish War, was preserved by friends in Kiev. It was quoted by Ehrenburg and others and excerpts were first partially published in Аитературное наследство 74 (1965); a censored version appeared as “Ненавижу войну: Из дневника 
1920 года Исаака Бабеля", Дружба народов 4, 5 (1989): 238-52; 24760. A full edited version appeared in Конармия. Рассказы. Дневники. Публицистика. Москва: Издательство “Правда", 1990. It then appeared in editions of Babel"s collected works from 1990, beginning with the two-volume Сочинения. In separate book form: Дневник 1920. Москва: МІК, 2000.

\section{Archival materials and correspondence}

Archival materials are kept in RGALI, Moscow, the manuscript division of IMLI, Moscow, and in the I.T. Holtzman collection, Hoover Institution, Stanford. There are letters to Babel"s friends the Slonims in the manuscript division of the Russian State Library. Babel's private correspondence has been published over the years in excerpts, in journals and his selected works. Letters to his family abroad have appeared in English, French, and Italian, and appear in truncated form together with letters to friends in volume four of Babel"s Собрание сочинений в 4-x томах. Москва: Время, 2006. Letters to his friend Isai Livshits have been brought together by E. I. Pogorel'skaia from the Livshits family archives in the Litera turnyi muzei in a volume of letters and archival material, Письма другу: Из архива И.Л.Аивщица. Сост. Е.Погорельская. Москва: Государственный дитературный музей / Три квадрата, 2007.

\section{Biographies and criticism}

Александров, Ростислав (А.Ю.Розенбойм). Волшебник из Одессы: По следам Исаака Бабеля. Одесса: Пласке, 2011.

Белая, Г., Добренко, Е., Есаулов, И. Конармия Исаака Бабеля. Москва: Российский гуманитарный университет, 1993.

Collection of three essays on Red Cavalry.

Bloom, H., ed. Modern Critical Views: Isaak Babel'. New Haven: Chelsea House, 1987.

Collection of critical essays on Babel', with an introduction by Harold Bloom and a new article by Victor Erlich.

Bloom, H., ed. Modern Short-Story Writers: Isaac Babel. Philadelphia: Chelsea House, 2004.

Student guide to four short stories, based on excerpts from the critical literature.

Carden, P. The Art of Isaac Babel. Ithaca: Cornell University Press, 1972. First book-length study in English on Babel"s poetics. 
Bibliography of Works by Babel' and Recommended Reading

Charyn, J. Savage Shorthand: The Life and Death of Isaac Babel. New York: Random House, 2005.

Biography by an author of popular fiction.

Ehre, M. Isaac Babel. Boston: G. K. Hall, 1986.

Twayne's series monograph on Babel"s life and works.

Ен, Аи-Су (Yeon, Lee Su.) Исаак Бабель, Конармия и Одесские рассказы: Поэтика ицикла. Санкт-Петербург: Міръ, 2005.

Monograph in Russian by a Korean scholar on the structural and aesthetic unity of Babel"s Red Cavalry and Odessa stories.

Falen, J. Isaac Babel: Russian Master of the Short Story. Knoxville: University of Tennessee Press, 1974.

Scholarly study of Babel"s life and works. With bibliography.

Freidin, G., ed. The Enigma of Isaac Babel: Biography, History, Context. Stanford, CA: Stanford University Press; 2009.

Collection of studies in biography and criticism.

Hallett, R. Isaac Babel. Letchworth: Bradda Books, 1972. Introduction to life and works.

Krumm, R. Isaak Babel: Eine Biographie. Norderstedt: Books on Demand $\mathrm{GmbH}, 2005$. Russian version: Исаак Бабель. Биография. Москва: РОССПЭН, 2008.

Певин, Ф. И. Бабель: Очерк творчества. Москва: Художественная литература, 1972.

Short account of the life and works, the first such book-length study in the USSR.

Либерман, Я.Л. Исаак Бабель глазами еврея. Екатеринбург: [n.p.], 1996. A supposedly "Jewish" reading of the work.

Luck, C. D. The Field of Honour: An Analysis of Babel"s "Na pole chesti". Birmingham: University of Birmingham, 1987. Birmingham Slavonic Monographs, 18.

Monograph on the "Na pole chesti" stories.

Luck, C. D. Figures of War: Two Cycles of Stories by Isaak Babel'. Oxford: Oxon Publishers for Essays in Poetics, 1992.

Study of the genesis of the Red Cavalry stories.

Luck, C. D. Figures of War and Fields of Honour: Isaak Babel's Red Cavalry. Keele: Keele University Press, 1995.

A further study of the genesis of the Red Cavalry stories. 
Bibliography of Works by Babel' and Recommended Reading

Luplow, C. Isaac Babel's Red Cavalry. Ann Arbor: Ardis, 1982. Monograph on the Red Cavalry stories.

Mann, R. The Dionysian Art of Isaac Babel. Oakland, CA: Barbary Coast Books, 1994.

A Nietzschean study.

Mendelson, D. Metaphor in Babel's Short Stories. Ann Arbor: Ardis, 1982. Study of poetic imagery in the stories.

Пирожкова, А.; Юргенева, Н. (ред.). И. Бабель: Воспоминания современников. Москва: Советский писатель, 1972. New unexpurgated edition: Воспоминания о Бабеле. Москва: Книжная палата, 1989.

Memoirs, with a preface by Fazil' Iskander, some new material, letters from Babel' to his family, and the account of Babel"s arrest by Antonina Pirozhkova.

Pirozhkova, A. N. At His Side: The Last Years of Isaac Babel. Trans. A. Frydman and R. Busch. South Royalton, Vermont: Steerforth Press, 1996.

Russian version of the memoir by Pirozhkova, partly published in воспоминания о Бабеле.

Пирожкова, А. Семь лет с Исааком Бабелем. New York: Слово, 2001. Republished with minor revisons in Собрание сочинений в 4-x mомах. Москва: Время, 2006. IV, 357-360.

Поварцов, С. Причина смерти-расстрел: Хроника последних дней Исаака Бабеля. Москва: Terra, 1996.

The full account of Babel"s arrest and death.

Rougle, C., ed. Red Cavalry: A Critical Companion. Evanston: Northwestern University Press, 1996.

Collection of critical essays on Red Cavalry and teaching guide.

Schreurs, M. Procedures of Montage in Isaak Babel's Red Cavalry. Amsterdam: Rodopi, 1989. Studies in Slavic Literature and Poetics, 15.

Study of cinematic techniques in the Red Cavalry stories.

Sicher, E. Style and Structure in the Prose of Isaak Babel'. Columbus, $\mathrm{OH}$ : Slavica, 1986.

Study of narrative structure and imagery in the short fiction of the twenties.

Смирин И.А. И.Э. Бабель в литературном контексте: Сборник статей.

Под ред. Н.А. Петровой. Пермь: Пермский государственный педагогический университет, 2005.

Collection of Smirin's essays on Babel'. 
Bibliography of Works by Babel' and Recommended Reading

Stora-Sandor, J. Isaac Babel': L'homme et l'oeuvre. Paris: Klincksieck, 1968. A pioneering study of life and works, in French.

Тынянов, Ю.; Казанский, Б. (ред.). И.Э.Бабель: Статьи и материаль. Аенинград: Академия, 1928. Reprinted Letchworth: Bradda Books, 1973. Hereafter И.Э.Бабель: Статьи и материальь.

Collection of essays in the formalist series "Masters of Contemporary Literature". Contents: И.Бабель, "Автобиография"; Н.Степанов, "Новелла Бабеля"; П.Новицкий, “Бабель"; Г.Гуковский, "Закат".

van Baak, J. The Place of Space in Narration: A Semiotic Approach to the Problem of Literary Space. With an Analysis of the Role of Space in I. E. Babel's Konarmiia. Amsterdam: Rodopi, 1983.

Wolf, I. Tertium non datur: Ideologie und Soziologie in Isaak Babel"s Konarmija. Frankfurt: Peter Lang, 2001.

Monograph on Red Cavalry stories in German.

Жолковский, А.К., Ямпольский, М.Б. Бабель/Babel'. Москва: Carte Blanche, 1994.

Coauthored book on intertextuality in the short stories. Two chapters preprinted, Новое литературное обозрение 4 (1993): 197-227.

Жолковский А.К. Полтора рассказа Бабеля: "Гюи де Мопассан" и "Справка/Гонорар": Структура, смысл, фон. Москва: КомКнига, 2006. A structuralist study of intertextual relations with Maupassant, Sholom Aleichem, and Gor'ky. 


\section{Notes}

\section{Introduction}

1 Quoted in Савва Голованивский, "Великий одессит”, Воспоминания o Бабеле, сост. А. Пирожкова, Н.Юргенева (Москва: Книжная палата, 1989), 213.

2 "Introduction," Great Jewish Short Stories, ed. Saul Bellow (New York: Dell Publishing Co., 1963), 16.

3 Г.Белая, "Конармия И.Бабеля: Вчера и сегодня", in her Дон Кихоты 20-x годов: "Перевал" и судьба его идей (Москва: Советский писатель, 1989), 149-69; revised version: Дон Кихоть революичии - опыт побед и поражений, изд. 2-е, допол. (Москва РГГУ, 2002); С. Гандлевский, “Гибель с музыкой (о Бабеле)", Знамя 9 (2009): 187-97.

4 И.Яркевич, “Бабель как Маркиз де Сад русской революции”, Независимая газета 16 марта 1994. English version: "Babel' as the Marquis de Sade of the Russian Revolution," trans. A. Bromfield, Glas 8 (1994): 227-30.

5 W. Cukierman, “Новый документ”, Глагол 3 (1981): 298-99.

6 Ростислав Александров, Волшебник из Одессы: По следам Исаака Бабеля (Одесса: Пласке, 2011), 22-24. Aleksandrov's account gives no documented sources and is partly based on hearsay and memoirs.

7 For anecdotes about such pranks see А.Пирожкова, “Семь лет с Исааком Бабелем", Собрание сочинений, IV, 466-67. Ehrenburg recalls Babel"s compulsive secretiveness in his memoirs, И.Эренбург, Аюди, zоды, жизнь: Воспоминания (Москва: Советский писатель, 1990), I, 469.

8 Пирожкова, “Годы, прошедшие рядом (1932-1939)”, Воспоминания о Бабеле, 272. He also introduced Semyon Gekht to the Russian poet Esenin as his son (С.Гехт, "У стены Страстного монастыря в летний день 1924 года", Воспоминания о Бабеле, 54).

9 Letter to A. G. Slonim, 7 December 1918, Собрание сочинений, IV, 5.

10 Bellow, “Introduction," 15-16. 
11 David Theo Goldberg and Michael Krausz, "The Culture of Identity," in Jewish Identity, ed. David Theo Goldberg and Michael Krausz (Philadelphia: Temple University Press, 1993), 1.

12 Moss, Jewish Renaissance in the Russian Revolution (Cambridge, MA: Harvard University Press, 2009). See also David Shneer's account of literary politics in Yiddish secular culture, Yiddish and the Creation of Soviet Jewish Culture, 1918-1930 (Cambridge: Cambridge University Press, 2004).

13 See Steven J. Zipperstein, The Jews of Odessa: A Cultural History, 17941881 (Stanford: Stanford University Press, 1985).

14 See early assessments of Odessa's cosmopolitan traditions in А.M.деРибас, Из прошлаго Одессь:: Сборник статей (Одесса: Маразди, 1894); А.Кирпичников, “Из истории умственной жизни Одессы”, Очерки по истории новой русской литературы (Санкт-Петербург, 1896), 383-420.

15 "A Port, Not a Shtetl: Reflections on the Distinctiveness of Odessa," Jewish Culture and History 4, 2 (2001): 173-78; see chapter three.

16 Mordecai Altshuler, Soviet Jewry on the Eve of the Holocaust: A Social and Demographic Profile (Jerusalem: Centre for Research of East European Jewry, Hebrew University of Jerusalem, 1998), 14, 36, 40, 225.

17 See Steven J. Zipperstein, "Remapping Odessa," in his Imagining Russian Jewry: Memory, History, Identity (Seattle: University of Washington Press, 1999), 63-86.

18 See Jarrod Tanny, City of Rogues and Schnorrers: Russia's Jews and the Myth of Old Odessa (Bloomington: Indiana University Press, 2011). Tanny identifies Ostap Bender's coded Jewishness as indicating a criminality associated with Odessa (104-07).

19 Maurice Friedberg has attempted to reconstruct Odessa's social life based on interviews with Soviet emigrants in How Things Were Done in Odessa: Cultural and Intellectual Pursuits in a Soviet City (Boulder, CO: Westview Press, 1991).

20 Robert A. Rothstein, "How It Was Sung in Odessa: At the Intersection of Russian and Yiddish Folk Culture," Slavic Review 60, 4 (2001): 781-801. For Odessa underworld songs that became popular see Boris Briker, "The Underworld of Benia Krik and I. Babel"s Odessa Stories," Canadian Slavonic Papers 36, 1-2 (1994): 124-28.

21 В.Шкловский, “Юго-Запад”, Аитературная газета 5 января 1933, 3. 
22 "Some Themes and Archetypes in Babel"s Red Cavalry," Slavic Review 53, 3 (1994): 653.

23 Rebecca Stanton, "Identity Crisis: The Literary Cult and Culture of Odessa in the Early Twentieth Century," Symposium 57, 3 (Fall 2003): 117.

24 Е.Каракина, По следам того-запада (Новосибирск: Свиньин и сыновья, 2006). For a polemical repudiation of these claims see О.Кудрин, "Уроки одесской шкоды и гребни одесской волны", Bопросы литературы 3 (2012): 9-64.

25 А.Воронский, "И. Бабель", Аитературные типь (Москва: Круг, 1925), 101; translated by James Karambelas as "Isaac Babel'," in Twentieth-Century Russian Literary Criticism, ed. V. Erlich (New Haven: Yale University Press, 1975), 182.

26 Замятин, Аиц्а (New York: Chekhov Publishing House, 1955), 252.

27 Замятин, Аица, 225; translated as “On Literature, Revolution, and Entropy," in A Soviet Heretic: Essays by Yevgeny Zamyatin, ed. and trans. Mirra Ginsburg (Chicago: University of Chicago Press, 1975), 121-23.

28 “И.Бабель: Критический романс", Леф 2 (1924): 152-55.

29 Shneer, Yiddish and the Creation of Soviet Jewish Culture, 1918-1930, 231, n1.

30 Moss, Jewish Renaissance in the Russian Revolution, 69-70.

31 Harriet Murav, Music from a Speeding Train: Jewish Literature in PostRevolution Russia (Stanford: Stanford University Press, 2011), 3-5. See chapter six.

32 Quoted in Victor Erlich, Modernism and Revolution: Russian Literature in Transition (Cambridge, MA: Harvard University Press, 1994), 120.

33 Nakhimovsky, Russian-Jewish Literature and Identity: Jabotinsky, Babel, Grossman, Galich, Roziner, Markish (Baltimore: Johns Hopkins University Press, 1992), 106.

34 Maxim Shrayer, in his pioneering study of Bagritsky, argues for a much wider definition of the poet's Jewishness (Russian Poet/Soviet Jew: The Legacy of Eduard Bagritskii [Lanham MD: Rowman \& Littlefield, 2000]). See Gregory Freidin, “Eduard Bagritsky: Soviet Poet/Russian Jew. Review essay of Maxim D. Shrayer. Russian Poet/Soviet Jew: The Legacy of Eduard Bagritsky," Russian Review 62, 3 (July 2003): 446-49.

35 The Bnei 'akiva (Sons of Akiva) are the youth movement of the religious Zionist party Po'el mizrakhi (founded 1929); considering their ideological 
orientation and the persecution of Zionist activity in the Soviet Union, the reference is surprising, and Babel' might have really meant Rabbi Akiva himself, the famous sage of Talmudic times, who was martyred by the Romans for his dedication to Judaism.

36 See Zvi Gitelman, Jewish Nationality and Soviet Politics: The Jewish Sections of the CPSU, 1917-1930 (Princeton: Princeton University Press, 1972).

37 See Sander L. Gilman, Jewish Self-Hatred: Anti-Semitism and the Hidden Language of the Jews (Baltimore: Johns Hopkins University Press, 1986).

38 See Sicher, Jews in Russian Literature after the October Revolution (Cambridge: Cambridge University Press, 1995), 112-64; А. Дежнев, Современники: Аитературно-критические очерки (Москва: Круг, 1927), 95-118.

39 Maurice Friedberg, "The Jewish Search in Russian Literature," Prooftexts 4, 1 (1984): 93-105. Sicher, Jews in Russian Literature after the October Revolution, 27-29.

40 История моей жизни (Москва: Советский писатель, 1936), 214.

41 See Sicher, Jews in Russian Literature after the October Revolution, 65-70; Judith G. Wechsler, "El Lissitzky's 'Interchange Stations': The Letter and the Spirit," in The Jew in the Text: Modernity and the Construction of Identity, ed. Linda Nochlin and Tamar Garb (London: Thames and Hudson, 1995), 187-200.

שמואל ווליץ, "מנחם מנדל" של שלום-עליכם כרובד ב'שנים-עשרה כסאות' של אילף 42

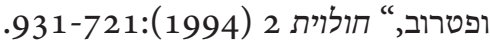

43 See Gabrielle Safran, "Isaak Babel"s El'ia Isaakovich as a New Jewish Type," Slavic Review 61, 2 (2002): 253-72.

44 М.Семанова, Чехов и Советская литература, 1917-1935 (Советский писатель: Ленинград, 1966), 165-69. See chapter five.

\section{Chapter One}

1 Of twenty-five agricultural machinery firms, five were in the hands of Jews in 1912 ("Одесса," Еврейская энцциклопедия [St. Petersburg: Brockhaus-Efron, 1913], XII, 60). More common was the Jewish middleman, or broker, like Tsudechkis who jokes about this in "Justice in Parenthesis" ("Справедивость в скобках"). In "Story of My Dovecote" we are told that the Jewish brokers instilled fear in peasants and landowners, who could not get away from them without buying something. 
2 Letter of 14 October 1931, Собрание сочинений, IV, 297; translated by Andrew R. MacAndrew and Max Hayward in Isaac Babel, The Lonely Years, 1925-1939: Unpublished Stories and Private Correspondence, ed. Nathalie Babel (New York: Farrar, Straus, 1964), 189. See Nathalie Babel, "Introduction," in Lonely Years, ix-xxviii.

3 Charles King, Odessa: Genius and Death in a City of Dreams (New York: Norton, 2011), 156.

4 King, Odessa, 157.

5 Babel' met Jabotinsky only once, in Paris in 1935, according to his testimony during interrogation by the NKVD, and he had little in common with the revisionist leader about to break from the mainstream Zionist movement (М.Соколянский, “Общие корни: Владимир Жаботинский и Исаак Бабель," Егупец̧/יעהופץ"К [Київ] 10 [2002]: 248-64 [in Russian]).

6 See Alice S. Nakhimovsky, Russian-Jewish Literature and Identity; Barry P. Scherr, "An Odessa Odyssey: Vladimir Jabotinsky's The Five," Slavic Review 70, 1 (2011): 94-115. See also Michael Katz, "Odessa's Jews: The End of Assimilation," Southwest Review 87, 2-3 (2002): 271-82.

7 Roshanna P. Sylvester, Tales of Old Odessa: Crime and Civility in a City of Thieves (DeKalb, IL: Northern Illinois University Press, 2005).

8 According to his sister Meri, quoted in Judith Stora-Sandor, Isaac Babel': L'homme et l'oeuvre (Paris: Klincksieck, 1968), 18-20.

9 М.М.Берков, “Мы были знакомы с детства,” Воспоминания о Бабеле, 203.

10 On the possible influence of Pater on Babel' see Philip Bullock, "The Cruel Art of Beauty: Walter Pater and the Uncanny Aestheticism of Isaak Babel"s Red Cavalry," Modern Language Review 104, 2 (2009): 499-529.

11 Берков, “Мы были знакомы с детства,” 204.

12 Roman Katzman, Poetics of Becoming: Dynamic Processes of Mythopoesis in Modern and Postmodern Hebrew and Slavic Literature (Frankfurt am Main: Peter Lang, 2005), 20-22. See also J. van de Stadt, "A Question of Place: Situating Old Shloime in Isaac Babel's Oeuvre," Russian Review 66, 1 (2007): 36-55.

13 Gor'ky used the paper to voice his belief in the role of the intelligentsia in the revival of moral values and to plead for a cessation of violence in politics, as well as, after October, for the restoration of individual freedom. See Maxim Gorky, Untimely Thoughts: Essays on Revolution, Culture and the Bolsheviks, 1917-1918, trans. H. Ermolaev (New York: Paul S. Erikson, 1968). 
14 Lonely Years, xiv. See Stora-Sandor, Isaac Babel, 25-26.

15 Babel' implied that he had been more or less boycotted by Russian émigrés in Paris as a Cheka agent in the speech he made in his defense at a meeting of the secretariat of the writers' organization FOSP, Moscow, 13 July 1930 (transcript in IMLI, f. 86 op. 1 no. 5, 1). There is evidence Babel' was writing a novel about the Chekists in the 1930s; see note 63 below.

16 “И.Бабель: Критический романс," Аеф 2 (1924): 152-55.

17 See Efraim Sicher, "Art as Metaphor, Epiphany, and Aesthetic Statement: The Short Stories of Isaak Babel'," Modern Language Review 77, 2 (1982): 387-96.

18 Seе Е.САивкин, “Евреи безоружные и вооруженные (опыт паралиельного чтения Конармии и Одесских рассказов Исаака Бабеля)," Вестник Еврейского университета 15 (1997): 137-46.

19 The original manuscript, given by Babel' to a typist in the editorial offices of the Odessa journal Moriak, is not extant and so it is not possible to conclusively establish authorship of the text, which probably dates from around 1923.

20 И. Н. Шкляев, "Мишка Япончик," in his Odeсcа в смутное время (Одесса: Негоциант, 2004), 17-29. For some of the legends surrounding Misha Yaponchik, see Boris Briker, "The Underworld of Benia Krik and I. Babel"s Odessa Stories," 129-31; Tanny, City of Rogues and Schnorrers, 76-78, 160-67; Виктор Ковальчук, “Михаил Яковлевич ВинницкийБеня Крик: Война в цилиндрах," www.pseudology.org/Babel/ BenyaKrik.htm; Аркадий Кравец, "Кородь Молдаванки," Зеркало недели 12-18 июля 1997; http://www.zn.ua/3000/3150/12354/.

21 See Carol Avins, "Jewish Ritual and Soviet Context in Two Stories of Isaac Babel'," in American Contributions to the XII International Congress of Slavists, ed. Robert A. Maguire and Alan Timberlake (Bloomington: Slavica, 1998), 11-20; Anna Shternshis discusses the case of a failed circumcision trial held in Odessa's Opera House in 1928 (Soviet and Kosher: Jewish Popular Culture in the Soviet Union, 1923-1939 [Bloomington: Indiana University Press, 2006], 95).

22 See C. D. Luck, Figures of War and Fields of Honour: Isaak Babel's Red Cavalry (Keele: Keele University Press, 1995).

23 Diary, Zhitomir, 5 July 1920 (the dates in the manuscript are generally given in Roman numerals, and Babel' seems to have mistakenly written VI for VII; historical facts and the calendar corroborate the date of the first extant entries from July 1920, not June). 
24 Lesniów, July 26, 1920, Собрание сочинений, II, 264. Babel', 1920 Diary, trans. H. T. Willetts, ed. Carol Avins (New Haven: Yale University Press, 1995), 38.

25 Quoted in Дeтство, 362.

26 This gives credence to Furmanov's testimony that Babel' told him of his original plans to write something like fifty chapters (Д. Фурманов, Собрание сочинений [Москва: Государственное издательство художественной дитературы, 1961], IV, 240). The drafts were first published in censored, abridged form by Smirin and Siniavsky in 1965 and appeared in full in 1995; seе Собрание сочинений, II, 335-66.

27 See chapter two.

28 “Рыцари цивилизации," Красный кавалерист 14 августа 1920, 2; "Недобитые убийцы," Красный кавалерист 17 сентября 1920.

29 О.В.Будницкий, Российские евреи между красными и белыми (19171920) (Москва: РОССПЭН, 2005), 438-93.

30 See Carol Avins, "Kinship and Concealment in Red Cavalry and Babel"s 1920 Diary," Slavic Review 53, 3 (1994): 694-710.

31 “Бабизм Бабеля из Красной нови," Октябрь 3 (1924): 196-97.

32 G. Reavey and M. Slonim, eds., Soviet Literature: An Anthology (1933), quoted in E. H. Carr, A History of Soviet Russia: Socialism in One Country, 1924-1926 (London: Macmillan, 1959), II, 77. Emphasis in the original.

33 “Бабизм Бабеля," 196-97.

34 Budenny's remark that Babel' was hostile by nature might possibly be a sly reference to his Jewish identity.

35 On the place of Red Cavalry in the struggle for freedom in literature see Г.Белая, “Конармия И.Бабеля: Вчера и сегодня," Дон-Кихоть 20-х годов: Перевал и судьба его идей (Москва: Советский писатель, 1989), $149-69$.

36 “Письмо в редакцию," Октябрь 4 (1924): 228.

37 Letter to the editor of Krasnaia nov', 4 July 1924, RGALI f. 602, op. 1, ed. khr. 1718. Incidentally, Mel'nikov's letter, which sought to correct a detail in the story (he never resigned from the Party), not only corroborated Babel's version of events in the Polish-Soviet campaign, but complained that Babel' had not shown the looting of Rovno (Równe) by Red troops.

38 Letter to D. A. Furmanov, 4 February 1926, in Собрание сочинений, IV, 50. On Babel"s relations with Furmanov see Л.Куванова, “Фурманов и Бабель," Аитературное наследство 74 (1965): 500-12. 
39 Lonely Years, 65.

40 В.Вешнев, “Поэзия бандитизма," Молодая гвардия 7-8 (1924): 274-80.

41 Г.Горбачев, “О творчестве Бабеля и по поводу его,” Звезда 4 (1925): 270-86.

42 А.Лежнев, “Литературные заметки, 3: И.Бабель," Печать и революция 4 (1925): 149-51; “И.Бабель,” Печать и революцчия 6 (1926): 82-86.

43 Gor'ky, letter to V. Vishnevsky of April 3, 1930 in Литературное наследсвmo 70 (1963), 48. Vishnevsky had written a play about Budenny's First Horse Army, An Optimistic Tragedy (Onmuмuстическал mрагедия).

44 Lonely Years, 61; Собрание сочинений, IV, 22.

45 Carol Luplow, "Isaak Babel' and the Jewish Tradition: The Childhood Stories," Russian Literature, 15, 3 (1984): 255-78; Hamutal Bar-Yosef, "On Isaac Babel's 'The Story of My Dovecot'," Prooftexts 6, 3 (1986): 264-71.

46 Slezkine, The Jewish Century (Princeton: Princeton University Press, 2004), 105-203.

47 In the original Turgenev text, the boy later dreams his father strikes Zinaida on the forehead, but Babel' has the father strike the girl on her cheek.

48 Slezkine records several examples of this literary rite de passage (a substitute for the bar mitzvah reading) and of the conscription of Russian literary figures as an entry ticket into Russian culture (Jewish Century, 131-36).

49 К.Паустовский, Время больших ожиданий (Москва: Советский писатель, 1960), 151-52.

50 Letter to Gor'ky, June 25, 1925, Собрание сочинений, IV, 32.

51 In the first publication of "My First Love" the narrator's father is addressed as "Babel'," thus sharpening the personal crisis and emphasizing the boy's estrangement from his identity.

52 This significant phrase was removed from later editions, presumably in order not to give the impression that anti-Semitic troubles of Tsarist times continued to affect the writer after the Revolution.

53 See Sander L. Gilman, The Jewish Body (New York: Routledge, 1991).

54 IMLI f. 86, op. 1, ed. khr. 6. 
55 Letter to Isai Livshits, 10 January 1928, Письма другу: Из архива И.Л.Аивщица, сост. Е.Погорельская (Москва: Государственный литературный музей / Три квадрата, 2007), 28.

56 Letter to his mother, 20 October 1928, Lonely Years, 106; Собрание сочинений, IV, 244.

57 As shown by an application for a writer's apartment, dated 19 January 1930, IMLI f. 86, op. 1, ed. khr. 8. See letter of 26 May 1930, Lonely Years, 140. Babel' departed on his own ostensibly because Zhenia had to look after her mother in Paris after her brother left for America.

58 See Babel"s letters to Kashirina, Собрание сочинений, IV, 11-256.

59 Пирожкова, “Семь лет с Исааком Бабелем," Собрание сочинений, IV, 453.

60 Пирожкова, “Годы, прошедшие рядом (1932-1939),” Воспоминания о Бабеле, 272.

61 Letter of 31 July 1928 from St. Idelsbad, Belgium, Собрание сочинений, IV, 231.

62 Despite the failure on the stage at MKHAT, in 1936 Dovid Bergelson made a Yiddish translation for Solomon Mikhoels' State Jewish Theater. Mikhoels, the leading Yiddish actor and director and for many years a friend of Babel', was cast for the role of Mendel; a different translation was used for the Belorussian Jewish Theater production which was performed in 1935.

63 Sergei Povartsov writes on the basis of Dmitri Furmanov's diary records of meetings with Babel' in 1925-1926 and interviews with Babel"s contemporaries that this was a novel, from which Babel' read excerpts at a private gathering in 1937; as Povartsov notes, the Cheka had been a prohibited literary theme since 1930, but this apparently did not deter Babel' even at the height of the Purges (С. Поварцов, Причина смерти-расстрел: Хроника последних дней Исаака Бабеля [Москва: Terra, 1996], 2-22). The play about Kotovsky was written in 1937 but has been lost (see Babel"s note to Isai Livshits empowering him to receive a fee, 17 May 1937, Письма другу, 99).

64 See chapter seven.

65 М.Горький, “Рабселькорам и военкорам о том, как я учился писать," Правда, 30 сентября 1928, 3.

66 С.Буденный, “Открытое письмо М.Горькому," Правда 26 октября 1928,4 . This letter was actually written by S. Orlovsky, former secretary 
of the Revolutionary-Military Council of the First Horse Army. It is quite possible that Budenny's original attack on Babel' had also been penned by a Party hack.

67 М.Горький, “Ответ С.Буденному,” Правда 27 ноября 1928, 5. The MS of this letter in Gor'ky's archive uses much sharper language, but the editors of Pravda persuaded Gor'ky to tone it down. Babel' thought Gor'ky had been too soft in his reply (letter of 29 November 1928 to Anna Slonim, Собрание сочинений, IV, 255).

68 М.Горький, "Механическим гражданам СССР: Ответ корреспондентам," Правда 7 октября 1928, 3-4; "О трате энергии," Известия 15 сентября 1929, 2.

69 Aleksander Dan, “Izaak Babel," Wiadomości literackie, 21 (1930), 2.

70 The interview was featured in the Parisian Dernières nouvelles, $13 \mathrm{Ju}$ ne 1930 and published the same year as if it were the author's own confession in the Hebrew literary magazine Ketuvim. The Israeli poet Avraham Shlonsky apparently took it seriously enough to publish it without commentary in his translations of Babel"s stories,

יצחק באבל, סיפורים (מרחביה: ספרית פועלים, 1963), 343-342.

71 “Наши на Ривьере," Аитературная газета 10 июля 1930, 2. Jasieński was later arrested in Stalin's purge of the Polish Communist Party on 31 July 1938. He was sentenced to fifteen years and died of typhus in the Vladivostok transit camp (Robert Conquest, The Great Terror: Stalin's Purge of the Thirties, revised edition [Harmondsworth: Penguin Books, 1971], 585).

72 Аитературная газета, 15 июля 1930, 1.

73 Transcript of the meeting, IMLI, f. 86 op. 1 no. 5, 1; Собрание сочинений, III, 360-63.

74 Letter of 22 July 1930, Lonely Years, 144.

75 See his letter to the editor of Иитературнал газета, 17 июля 1930, Собрание сочинений, IV, 282.

76 Letter from Molodenovo, 8 February 1931, Lonely Years, 160.

77 Letter from Kiev, 15 December 1928, Lonely Years, 112.

78 Letter from Molodenovo, 16 December 1931, Lonely Years, 200.

79 Последние новости 3929 (декабрь 1931): 3-4.

80 Letter from Moscow, 2 January 1932, Lonely Years, 202. 
81 Letter to his mother from Molodenovo, 12 January 1932, Lonely Years, 205.

82 MS in RGALI f. 1559, op. 1, ed. khr. 3, published in Детство, 7-8.

83 "Appendix," in Red Cavalry and Other Stories, 343.

84 Первый всесоюзный съезд советских писателей: Стенографический отчет, ред. И.Дупполь, и др. (Москва: Государственное издательство художественной дитературы, 1934), 279.

85 Первый всесоюзный съезд советских писателей, 225-26.

86 Первый всесоюзный съезд советских писателей, 234-36.

87 Lionel Trilling seems to have understood this expression differentlythat the right to write badly was itself a right not to be given up easily ("Appendix," Red Cavalry and Other Stories, 343).

88 “Вакханалия переизданий," Правда 15 декабря 1936, 3.

89 В. Перцов, “Новая дисциплина,” Знамя 12 (1936): 238-41.

90 Letter of 11 March 1937, Lonely Years, 335.

91 И.Эренбург, Аюди, годы, жизнь: Воспоминания (Москва: Советский писатель, 1990), II, 486; С.Гехт. “У стены Страстного монастыря в летний день 1924 года," Воспоминания о Бабеле, 59-60.

92 For an account of this novella see Пирожкова, “Семь лет с Исааком Бабелем," Собрание сочинений, IV, 477-78.

93 See letter from Nal'chik, the provincial capital, 8 November 1933, Lonely Years, 242; Пирожкова, “Семь лет с Исааком Бабелем," Собрание сочинений, IV, 375-95. Babel' gave a two-hour talk in the House of Soviet Writers, Moscow, on 26 April 1935 on his contribution of stories about Kabardino-Balkariia to Gor'ky's planned anthology devoted to the second Five-Year Plan (Я.Э., "Встреча с Бабелем," Аитературная zазета, 5 мая 1935, 6). Babel' intended to use this material for a commission from the Party publishing house Politizadat, where his friend Isai Livshits worked (see letter to Isai Livshits, 29 December 1933, Письма другу, 91).

94 Пирожкова, "Семь иет с Исааком Бабелем," Собрание сочинений, IV, 396-402; Vadim Zakharovich Rogovin, Stalin's Terror of 1937-1938: Political Genocide in the USSR (Sheffield: Mehring Books, 2009), 143.

95 Letter of 19 June 1936, Lonely Years, 309.

96 Пирожкова, “Семь иет с Исааком Бабелем," Собрание сочинений, IV, 370. 
97 See letter of 25 October 1936, Lonely Years, 322-24; Пирожкова, “Семь лет с Исааком Бабелем," Собрание сочинений, IV, 442-50..

98 For example, see the transcript of Babel"s speech of 26 March 1936, IMLI f. 41, op. 1, nо. 228, 87-93; Собрание сочинений, III, 364-69.

99 Edited transcript of Babel"s remarks made at an evening arranged by the young writers' journal Literaturnaia ucheba at the Union of Soviet Writers, 28 September 1937, Собрание сочинений, III, 392-404.

100 A rare example is "Ложь, предательство, смердяковина," Литературная газета, 26 января 1937, 4 (special issue dedicated to the show trials and including articles signed by many Soviet writers).

101 Letter to Efim Zozulia of 14 October 1938 from Peredel'kino, Собрание сочинений, III, 353-54. Fortunately for Babel', the bailiffs were instructed to leave essential furniture such as a writing table; one of the assessors happened on one occasion to be the poet Boris Slutsky, then a budding law student, who has left a memoir of the incident in which he recalls that Babel' had not left any other assessable furniture in his apartment and the bailiffs were disappointed (Slutsky, Things That Happened, ed. G. S. Smith [Moscow: Glas, 1999], 53-56).

102 Of the five stories he sent back with Gor'ky hoping they would restore him to favor in Russia, two ("Froim Grach" and "My First Fee") were not published in Babel"s lifetime. A variant of "My First Fee" did however appear in English translation in a Soviet publication, "A Reply to an Inquiry," International Literature 9 (1937): 86-88.

103 On his return to Moscow, Babel' attended a public debriefing on the congress, reported in "Широким фронтом против фашизма: Товарищи И.Бабель, В.Киршон и К.Аупполь о Конгрессе защиты культуры," Литературнал газета, 15 августа 1935. Babel' noted the care and attention Soviet writers visiting abroad received from the Motherland, doubtlessly a hint that his movements were restricted and he was under surveillance.

104 Letter of 13 November 1935, Lonely Years, 294.

105 “Багрицкий,” Эдуард Багрицุкий: Альманах, под ред. В.Нарбута (Москва: Советский писатель, 1936), 160-61.

106 “Скупой дитератрный рыцарь,” 30 дней 6 (1932): 35.

107 Letter to mother of 16 April 1938, Lonely Years, 359; Собрание сочинений, III, 352.

108 Эренбург, Аюди, годь, жизнь: Воспоминания, II, 158.

109 Эренбург, Аюди, годь, жизнь: Воспоминания, I, 471. 
110 Ervin Sinkó, Roman eines Romans: Moskauer Tagebuch (Köln: Verlag Wissenschaft und Politik, 1969); Б.Суварин, "Последние разговоры с Бабелем," Континент 23 (1980): 343-78.

111 Н.Мандельштам, Воспоминания (New York: Chekhov Press, 1970), 341; Пирожкова, “Семь лет с Исааком Бабелем," Собрание сочинений, IV, 472-75.

112 "Литературные мечтания," Аитературная газета 31 декабря 1938,5 .

113 Пирожкова, “Семь лет с Исааком Бабелем," Собрание сочинений, IV, 511-13. After the Thaw, El'sberg's role in the arrest of writers was investigated and he was thrown out of the Writers' Union in 1962, though he was later reinstated. El'sberg even wrote an appreciation of Babel"s "underrated" talent (Я.Эльсберг, “Об исследовании формообразующих факторов и их соотношений," Проблеми художественной формы социалистического реализма. [Москва, 1971] I, 162-65).

114 Н.Мандельштам, Воспоминания, 341; translated by Max Hayward, Hope Against Hope (Harmondsworth: Penguin Books, 1975), 385.

115 Пирожкова, “Семь иет с Исааком Бабелем," Собрание сочинений, IV, 427,

116 Seе Пирожкова, “Семь иет с Исааком Бабелем," Собрание сочинений, IV, 481, My Universities was released in 1940, but Babel"s name was dropped from the credits as he was by then a "non-person."

117 Letter to family from Leningrad, 20 April 1939, Lonely Years, 377. Babel' had gone to Leningrad to tie up some loose ends in his film work, but characteristically found time for visiting friends and sightseeing, summoning Pirozhkova to join him on the pretext of a sudden attack of asthma. James Falen interprets the film as containing anti-Stalinist insinuations ("A Note on the Fate of Isaac Babel'," Slavic and East European Journal 11 [1967]: 398-404); however, this children's film seems to be yet another routine assignment which Babel' wished to get over as quickly as possible.

118 Lonely Years, 379.

119 Unpublished memoir in the Odessa literary museum, published in Алена Яворская, “'Ну, писал там какой-то Бабель, и не стало его-делов!'” Мигдаль Times 52 (2004), accessed online http://www. migdal.ru/times/52/4803/; Iavorskaia's title refers to the song by Alexander Galich, "I too have gone gray" (“Вот пришли и ко мне седины..."). 
120 Пирожкова, "Семь лет с Исааком Бабелем," Собрание сочинений, IV, 481-84. The story of Babel"s fate at the hands of Beriia's henchmen, suppressed at the time of his rehabilitation during the Thaw, was first told in the Soviet Union in 1988 thanks to Gorbachev's policy of "openness." Excerpts from the dossier of NKVD Case No. 419 against I. E. Babel', opened 16 May 1939, in В.Шенталинский, Рабъ свободы: В литературных архивах КГБ (Москва: Parus, 1995), 26-81. Another description of Babel"s secret police dossier is to be found in С.Поварцов, Причина смерти-расстрел: Хроника последних дней Исаака Бабеля (Москва: Terra, 1996). The following account is based on these sources and on Arkadii Vaksberg's report on the "writers' conspiracy," “Процессы," Аитературная газета, 4 мая 1988, 12; as well as Pirozhkova's memoirs and her conversations with the present author in 1977. It should be pointed out that while Shentalinsky and Povartsov gained access to the original dossier, they do not always cite sources. Povartsov also improvises some imaginary reconstructions of "what it must have been like" without substantial documentation. Moreover, Shentalinsky was only too aware from his experiences trying to open up arrested writers' archives back in 1988 during glasnost' that the KGB had probably taken prophylactic measures to clean up some of the documents, that they were not going to readily reveal the identity of informers, and that cooperation depended on orders from above (Шенталинский, Рабы свободы, 23-25). Povartsov, who was told that prison and other records had not been preserved, believes that totalitarian habits die hard (sее Поварцов, Причина смерти, 47 n. 2). Both Shentalinsky and Povartsov vouch for the incredible order in which the pseudo-judicial process was documented, even in trivial details, but no credible explanation is given for missing material such as confiscated manuscripts, notebooks, and private correspondence. To this must be added the atmosphere in which Shentalinsky and Povarstov were writing, between the collapse of the communist system and the chaotic restructuring of Russian society, as well as against the background of revision of the Russian heritage and open anti-Semitism.

121 Povartsov states there is no firm evidence that Babel' was subjected to torture as was Meierhold (Поварцов, Причина смерти, 48), but it would be difficult to imagine Babel' assenting to the fabrication of nightmarish accusations against him without physical and psychological pressure.

122 Marc Jansen and Nikita Petrov, Stalin's Loyal Executioner: People's Commissar Nikolai Ezhov, 1895-1940 (Stanford: Hoover Institution Press, 2002), 186. 
123 Gor'ky was being increasingly isolated and he was irritated by the uncouth behavior of Stalin and his associates, as confirmed in Pirozhkova's memoirs and Babel"s own remarks when under interrogation (Шенталинский, Рабы свободы, 364-65). From the photograph of one of these meetings in 1936 showing Malraux talking to Babel', Kol'tsov, and Gor'ky, one can clearly see Gor'ky's dejected look (reproduced in Шенталинский, Рабъ свободь, facing p. 144). His son Maksim had died suddenly in mysterious circumstances, possibly poisoned by the secret police, and Stalin may have wanted the old man out of the way.

124 Why Ehrenburg was not arrested may have to do with services the French police suspected he was performing for Moscow, and he was useful as a Soviet propaganda tool to deny repression of other writers, especially during the anti-Cosmopolitan campaign after the war; ultimately it is a matter of speculation, though a question that preoccupies Ehrenburg himself in his memoirs. See Joshua Rubenstein, Tangled Loyalties: The Life and Times of Ilya Ehrenburg (New York: Basic Books, 1996).

125 Robert Conquest, The Great Terror: Stalin's Purge of the Thirties (London: Macmillan, 1968); revised edition, The Great Terror: A Reassessment (New York: Oxford University Press, 1990); the chapter entitled "On the Cultural Front" shows the extensiveness of the repression of Soviet writers from the twenties on in the context of secret police practice. See also Conquest, Inside Stalin's Secret Police: NKVD Politics, 1936-1939 (London: Macmillan, 1985).

126 Archive of the State Military Prosecutor's Office 39041-39, quoted Поварцов, Причина смерти, 170.

127 Ibid, 172.

128 Protocol of the session of the Military Collegium of the Supreme Court of the USSR, 26 January 1940, ibid, 175-76.

129 Povartsov dismisses this hypothesis (Поварцов, Причина смерти, 76).

130 Jonathan Brent comes to this conclusion after comparing the secret police files of Voronsky and Ezhov (Inside the Stalin Archives: Discovering the New Russia [New York: Atlas, 2008], 182-200).

131 Seе С.Поварцов, “Арест Бабеля: Расследование не закончено," Bonросы литературы 3 (2010): 400-15; Б.Сарнов, “Сталин и Бабель," Октябрь 9 (2010): 135-60.

132 Пирожкова, “Семь лет с Исааком Бабелем,” Собрание сочинений, IV, 506-10. 
133 Поляк, “И.Бабель," in И.Бабель, Избранное (Москва: Художественная дитература, 1966), 3. A different version of the preface appeared as "Бабель - новеллист," Известия Академии наук СССР: Аитература и язык 25, 4 (1966): 313-28.

134 Г.Белая, “Третья жизнь Исаака Бабеля," Октябрь 10 (1989): 185-97. For a post-Soviet perspective see her "На новый уровень исследования," Вопросы хитературы 1 (1995): 96-97.

135 Galina Belaia presumably has circles close to Pamiat' in mind when she describes the refusal by Moscow journals to publish Babel's 1920 Diary in summer 1987. It was eventually published after expurgation of expressions that might be considered derogatory of the Russian national character (““...Ненавижу войну': Из дневника 1920 года Исаака Бабеля," Дружба народов 4, 5 [1989]: 238-52; 247-60). Shentalinsky reports typical responses to his publication of Babel"s NKVD dossier that identified Babel' as a Russophobe and accused Shentalinsky of fanning anti-Semitism because Babel' had "betrayed" friends and colleagues under interrogation (Шенталинский, Рабы свободы, 300).

136 Сочинения (Москва: Художественная дитература, 1990).

137 Сочинения в 2-х томах (Москва: Теrra, 1996); Собрание сочинений в двух томах (Москва: Издательский дом Альд-Иитература, 2002).

138 Собрание сочинений в 4-х томах (Москва: Время, 2006).

139 The plan for this publication by the publishing house Sovetskii pisatel' speaks of a small print run $(20,000)$ and an original publication date set for November 1938, which could have been delayed as much by Babel"s characteristic prevarications as by political difficulties (archives of the Soviet Writers' Union, RGALI f. 631, opis' 15, no. 315).

140 Пирожкова, “Семь иет с Исааком Бабелем," Собрание сочинений, IV, 482.

\section{Chapter Two}

1 Michel Serres, L'interférence (Paris: Editions de Minuit, 1972), 157.

2 Murray Baumgarten, City Scriptures: Modern Jewish Writing (Cambridge, MA: Harvard University Press, 1982), 154-55.

3 Uriel Weinreich, Languages in Contact: Findings and Problems (Mouton: The Hague, 1967), 1. See also V. Ju. Rozencweig, Linguistic Interference and Convergent Change (Mouton: The Hague, 1976). 
4 Renate Lachmann, Memory and Literature: Intertextuality in Russian Modernism, trans. Roy Sellars and Anthony Wall (Minneapolis: Minnesota University Press, 1997), 15-16.

5 Quoted in Lachmann, Memory and Literature, 17.

6 Ibid.

7 Осип Мандельштам, Собрание сочинений, ред. Г.П.Струве и Б.А.Фидиппов (Вашингтон: Международное содружество 1967), 2-ое испр. изд., II, 619-620; Mandelstam, "An Army of Poets," The Complete Critical Prose and Letters, ed. Jane Gary Harris (Ann Arbor: Ardis, 1979), 193. On subtextual intereferentiality in Acmeist poetry, see В.Н.Топоров и Т.В. Цивьян, “О нервальском подтексте в русском акмеизме (Ахматова и Мандельштам)", Russian Literature 5, 15 (1984): 29-50, and В.Н.Топоров, “Еще раз о акмеистической цитате", in Miscellanea Slavica: To Honour the Memory of Jan M. Meijer, ed. B. J. Amsenga et al. (Amsterdam: Rodopi, 1983), 467-486.

8 On the Bergsonian influence on the Acmeists' understanding of time and space, see Lachmann, Memory and Literature, 242-46. I am not suggesting Babel' should be read as an Acemist, though his Odessa friend, the poet Vladimir Narbut, once thought he should (Nadezhda Mandelstam, Hope Abandoned: A Memoir, trans. Max Hayward [Harmondsworth: Penguin Books, 1976], 71-72).

9 Tynianov quoted in A. Крученых, Заумный язык у Сейфуллиной, Иванова, Леонова, Бабеля и других (Москва: Издание Всероссийского союза поэтов, 1925), 46.

10 Mikhail M. Bakhtin, The Dialogic Imagination: Four Essays, trans. Caryl Emerson and Michael Holquist (Austin: University of Texas Press, 1981); idem, Problems of Dostoevsky's Poetics, trans. Caryl Emerson (Minneapolis: University of Minnesota Press, 1984).

11 Julia Kristeva, "Word, Dialogue, and Novel" [1967], in The Kristeva Reader, ed. Toril Moi (New York: Columbia University Press, 1986), 34-61. See Lachmann, Memory and Literature, 101-21. For a survey of different approaches to intertextuality from Kristeva and Prague School structuralism to deconstruction and hypertext see Graham Allen, Intertextuality (London: Routledge, 2000); Heinrich E. Plett, ed., Intertextuality (Berlin: Walter de Gruyter, 1991). On intertextuality in Babel"s "Guy de Maupassant" see chapter five.

12 Lachmann, Memory and Literature, 27.

13 А.К.Жолковский; М.Б.Ямпольский, Бабель/Babel' (Mосква: Carte Blanche, 1994), 7. 
14 Marc Schreurs, Procedures of Montage in Isaak Babel"s Red Cavalry (Amsterdam: Rodopi, 1989), 96-99.

15 Избранные произведения, под ред. И.Э.Бабеля (Москва-Денинград, 1926-27).

16 Блуждающие звезды (Москва: Кинопечать, 1926).

17 “Семь лет с Исааком Бабелем”, Собрание сочинений, IV, 441-42.

18 Геннадий Эстрайх, “Советская карьера Шолом-Алейхема," Новое Питературное Обозрение 2 [114] (2012): 113-133.

19 Babel"s speech on the centenary of the birth of Mendel Mocher-Sforim at a commemorative meeting, Moscow 1936, is quoted in И.Эйдельман, "Менделе Мохер-Сфорим: На торжественном заседании в Доме союзов", Аитературная газета, 5 марта 1936, 6.

20 See details in the bibliography above.

21 А.Белов, “Когда герои Шолом-Алейхема объясняются на языке Моддаванки...", Мастерство перевода (1970): 457.

22 А.К.Жолковский, "Роман с гонораром (Бабель и ШоломАлейхем)", Полтора рассказа Бабеля "Гюи де Мопассан" и "Справкаа Гонорар": Структура, смыслл, фон (Москва: КомКнига, 2006), 149-67.

23 Itamar Even-Zohar, Papers in Historical Poetics (Tel-Aviv: Porter Institute for Poetics and Semiotics, Tel-Aviv University, 1978), 11-20, 57-59. For a critique of Even-Zohar's historical poetics, see Chana Kronfeld, On the Margins of Modernism: Decentering Literary Dynamics (Berkeley: University of California Press, 1996), 83-92.

24 Uriel Weinreich gives examples of Yiddish jokes about false equivalences between languages and a macaronic song based on code-switching (Languages in Contact, 68).

25 David G. Roskies, Against the Apocalypse: Responses to Catastrophe in Modern Jewish Culture (Cambridge, MA: Harvard University Press, 1984), 163-82.

26 Itamar Even-Zohar, "Polysystem Theory," Poetics Today 1, 1-2 (1979): 287-310; revised in "Polysystem Theory," Poetics Today 11, 1 (1990): 9-26.

27 Ibid, 23-25. See idem, "System, Dynamics and Interference in Culture: A Synoptic View," Poetics Today 11, 1 (1990): 85-96. For a critical introduction to polysystem theory, see Philippe Codde, "Polysystem Theory Revisited: A New Comparative Introduction," Poetics Today 24, 1 (2003): 91-126. 
28 Елизавета Полонская, "Встреча", Упряльй календарь: Стихи и поэм⿻ 1924-1927 (Денинград: Издательство писателей в Ленинграде, 1929), 88 (italics in the original). Seе М.Слоним, “Писатели-евреи в советской литературе", Еврейский мир [Нью Йорк], 2 (1944): 151; Leslie Dorfman Davis, Serapion Sister: Elizaveta Polonskaia (Evanston: Northwestern University Press, 1999).

29 Матвей Ройзман, “Коль Нидрэ”, Хевронское вино (Москва: Всероссийский союз поэтов, 1923), 3-12. Seе Галина Синило, Танах и мировая поэзия (Минск: Экономпресс, 2009), 675-98; and see the biographical note on Roizman in Поэты-имажинисты, сост. Э.М.Шнейдерман (Санкт-Петербург: Петербургский писатель, 1997), 367-69. On the identification of Jewish poets with the Marranos see the Introduction above.

30 А. Дежнев, Современники: Аитературно-критические очерки (Москва: Круг, 1927), 95-118.

31 Yiddish curses typically wish ill-health on various parts of one's נחום שטוטשקוף, דער אוצר פון דער אידישער שפּראָר 639-635, (ניו-יארק: ייווֹ, 1952)

[Hershel Ostropol: the world הערשעלע אָסטרופולער, דער ועלט בערימטער ויצטונג 32 [1, renowned trickster] (New York: Hebrew Publishing Company, [1925]), 63-66. These folk-tales would probably have been known to Babel' from their oral retelling, but a version of the story had appeared in an anthology of anecdotes about Hershel of Ostropol published in Russian in 1897 (מירון ואיסמן, "בּאַבּבעל און הערשעלע אָסטרופּולער," סובייטיש היימלאֵנד, 3 [1989]: 129-125).

33 Seе Ефим Эткинд, “О поэтическом 'импорте' и, в частности, о еврейской интонации в русской поэзии двадцатых годов", Cahiers du monde russe et soviétique 26, 2 (1985): 193-217.

34 Ziva Amishai-Maisels, "Chagall's Jewish In-Jokes," Journal of Jewish Art 5 (1978): 76-93; Benjamin Harshav, "The Role of Language in Modern Art: On Texts and Subtexts in Chagall's Paintings," Modernism/ Modernity 1, 2 (1994): 51-87.

35 Влас Дорошевич, “Одесский язык”, in Ю. Кушак, ред., Одесский Юмор: Антология сатирь томора России ХХ века (Москва: Эксмо, 2007), 35-37.

36 А.Куприн, Собрание сочинений (Москва: Издательство художественной литературы, 1972), V, 475.

37 Zamiatin said this in a lecture which he gave at Petrograd's House of Art in 1920-1921, "About Language" ["О языке"], A Soviet Heretic, 180. 
38 See Walenty Cukierman, "The Odessan Myth and Idiom in Some Early Works of Odessa Writers," Canadian-American Slavic Studies 14, 1 (1980): 36-51.

39 On Zhvanetskii's use of a repressed Odessa "Jewish" humor see Alice Nakhimovsky, "Mikhail Zhvanetskii: The Last Russian-Jewish Joker," in Forging Modern Jewish Identities: Public Faces and Private Struggles, ed. Michael Berkowitz, Susan L. Tananbaum, and Sam W. Bloom (London: Vallentine Mitchell, 2003), 156-79; Tanny, City of Rogues and Schnorrers, 145-50.

40 Sее А.Селищев, Язык революиионной эпохи: Из наблюдений над русским языком последних лет, 1917-1926 (Москва: Работник просвещения, 1928).

41 Inna Kabanen, "Johdatus Odessan Kielen Erikoispiirteisiin (Введение в особенности одесского языка)", Masters Dissertation, University of Helsinki, 2008. www.helsinki.fi/venaja/opiskelu/graduja/kabanen.pdf, pp. 39-40.

42 Kabanen, "Johdatus Odessan Kielen Erikoispiirteisiin"; Є.М.Степанов, Російське мовлення Одеси: Монограбія (Одеса: Одеський національний університет ім. І.І.Мечникова, 2004); Н.Б.Мечковская, "Русский язык в Одессе: Вчера, сегодня, завтра", Russian Linguistics (2006): 263-81.

43 В.Ф.Шишов и А.А.Стецюченко, "Одессизмы в рассказах Бабеля", Язык и стиль произведений И. Э. Бабеля, Ю. К. Олещи, И. А. Ильфа и Е. П. Петрова: Сборник научных трудов, ред. Ю.Карпенко и др. (Киев: УМКВО, 1991), 28-34.

44 Ibid, 33.

45 Дорошевич, “Одесский язык”, 37.

46 В. М. Попов, Словарь воровского и пристанского языка (Киев, 1912); С.Потапов, Блатная музыка (Москва, 1927).

47 Cf. Kabanen, “Johdatus Odessan Kielen Erikoispiirteisiin," 41, 42-3.

48 Селищев, Язык революичионной эпохи, 40. Cf. Yiddish פֵַ (“a few”) and standard napa ("a pair of"), a Petrine borrowing from Middle High German through Polish.

49 Jarrod Tanny seems to understand the "odesskii iazyk" as the language of Yiddish-speaking tricksters, and thus privileges its use in fiction and in the myth of "Old Odessa" over its usage in real life (City of Rogues and Schnorrers, 40, 45, 71). 
50 Rachel Rubin is surely not correct when she connects the Russian word for buckwheat porridge to the Aramaic expression for an irresoluble legal problem arising from an apparent contradiction in the text of the Talmud, kashia (Jewish Gangsters of Modern Literature [Urbana: University of Illinois Press, 2000], 41). Here and elsewhere Rubin seems to have taken Yiddish and Odessa idioms literally.

51 Дума про Опанаса (Москва: Издательство художественной иитературы, 1975), 51.

52 Четки (Берлин: Эфрон, 1920), 20.

53 М.Соколянский, “Общие корни: Владимир Жаботинский и Исаак Бабель": 260-62.

54 Roshanna P. Sylvester, Tales of Old Odessa, 79-80.

55 И.В.Герасимов, “'Мы убиваем только своих’: Преступность как маркер межэтнических границ в Одессе начала XX века (19071917 гг.)", Ab Imperio (January 2003): 209-60. In the ethnic breakdown of statistics in the pre-Revolutionary period, Jews stand fairly low in incidents of reported crime. The middle-class press, on the other hand, represented the Moldavanka bandits as a threat to bourgeois property and decency; see Rochelle Sylvester, Tales of Old Odessa.

56 See Vera von Wiren-Garczynski, "Language and Revolution: The Russian Experience of the Twenties," Canadian-American Slavic Studies 2, 2 (1968): 195.

57 Boris Briker, “The Underworld of Benia Krik and I. Babel"s Odessa Stories," 127 note 21.

58 A similar point is made by Rubin (Jewish Gangsters of Modern Literature, 43).

59 Other names are also meaningful in the Odessa Stories - in Yiddish, Liubka Shneeveis is "Snow White" and in the early publications of the story she is nicknamed "Ко́зак" (not Казак), which in Yiddish resounds with the associations of the Cossack as a figure of brutal strength and menace, out of place in a Jewish milieu (see История моей голубятни [Москва-Денинград: Земля и фабрика, 1926], 43-55). In Russian, Levka Byk is an ox, and Froim Grach is a rookie. "Peace has departed from the house of the Kriks" ("Покой ушел из дома Криков" [Детство, 287]) in the story "Sunset" because they are literally a family of shouts and yells (Крики); the equivalent Shrayer in Yiddish is a not uncommon family name; appropriately, Madame Golubchik has difficulty raising a yell from Mendel once he is knocked down flat on the ground by his sons: "shout something, Mendel!" ("Кричи чтонибудь, Мендель!" [Детство, 285]). Another Yiddish in-joke might 
be the innkeeper's name in "Pan Apolek," Shmerel' (a traditional Jewish name), who rushes after Apolek like a "shmerel" (a hasty, precipitous person in Yiddish) when he realizes he has not been paid. Apolek himself might be named for the Yiddish term for a Pole in the pejorative sense of an untrustworthy drunkard; see Maurice Friedberg, "К вопросу о прототипе героя рассказа Бабеля 'Пан Аполек', Bопросы литературы 5 (1996): 324-34; idem, "Yiddish Folklore Motifs in Isaac Babel"s Konarmiia," in Modern Critical Views: Isaac Babel, ed. Harold Bloom (New Haven: Chelsea House, 1987), 191-98.

60 Rubin, Jewish Gangsters of Modern Literature, 24.

61 The Modern Jewish Canon: A Journey Through Language and Culture (New York: Free Press, 2000), 93-119.

62 A version with significantly different punctuation appears in Осип Мандельштам, Собрание сочинений, I, 70.

63 See Dmitri Segal's survey of Mandelstam's and other poets' contributions to the daily press, "“Сумерки свободы': о некоторых темах русской ежедневной печати 1917-1918 гг.", Минувщее: Исторический алманах 3 (1991): 131-96. See also Nils Åke Nilsson, ed., Art, Society, Revolution: Russia, 1917-1921 (Stockholm: University of Stockholm, 1979).

64 As is clear in another poem published in Vecherniaia zvezda on 15 March 1918, “В Петрополе прозрачном мы умрем" (Сегаль, “'Сумерки свободы'", 184). However, despite the coincidence of the star in the newspaper's title and the topicality of events, it is evident Mandelstam had penned his verse some time earlier. The cold yellow sun of mythical Petropolis was an important cultural referent (see chapter five).

\section{Chapter Three}

1 See Zipperstein, The Jews of Odessa.

2 John Klier, "A Port, Not a Shtetl: Reflections on the Distinctiveness of Odessa," in Port Jeww: Jewish Communities in Cosmopolitan Maritime Trading Centres, 1550-1950, ed. David Cesarani (London: Frank Cass, 2002), 173-78.

3 See Zipperstein, Imagining Russian Jewry, 63-87.

4 Bella Vernikov, "Russian-Jewish Writers of Odessa in the Second Half of the $19^{\text {th }}$ and the Beginning of the $20^{\text {th }}$ Century: Toward a Definition of Russian-Jewish Literature as a Socio-Cultural Phenomenon," Ph.D. dissertation, Hebrew University of Jerusalem, 2001.

יעקב פיכמן, "נוסח אודסה," סופרים בחייהם (תל אביב: מצדה, 1942), 8-5. 
6 Ezra Spicehandler, "Odessa as a Literary Center of Hebrew Literature," in The Great Transition: The Recovery of the Lost Centers of Modern Hebrew Literature, ed. Glenda Abramson and Tudor Parfitt (Totowa, NJ: Rowman \& Allanheld, 1985), 75-90.

7 Shachar Pinsker, "Spatializing the Margins: Hebrew Modernism and the Urban Experience-Odessa and Warsaw: A Tale of Two Centers?" in his Literary Passports: The Making of Modernist Hebrew Fiction in Europe (Stanford: Stanford University Press, 2011), 39-48.

8 פרץ הרשביין, אין גאנג פון לעבן: זכרונות (ניו-יאָרק: ציקא, 1948)

י"ח רבניצקי, דור וסופריו: רשימות ודברי-זכרונות על סופרי דורי (תל אביב :דביר, 9 .(1937-1926

אליעזר שטיינמן, "דבש באודסה," מזניים 14 [37], 2 (1962): 173-166; 14 [37], 4210 $258-251:(1962)$.

שמואל אוסישקין, אמא אודיסה: זכרונות ילדות ונעורים, 1904-1919 (ירושלים: הפדרציה 11 הציונית, 1984).

12 See Chana Kronfeld, On the Margins of Modernism, 5-13.

13 Pinsker, "Spatializing the margins," 47-48.

אביגדור המאירי, בין שני האדם; ראינוע-אודיסה תרע“ט-תר"ף (ירושלים: ועד הכתב/ 14 תל אביב: השחר, 1929).

15 Alan Mintz, Hurban: Response to Catastrophe in Hebrew Literature (New York: Columbia University Press, 1985), 8.

16 Ruth R. Wisse, The Modern Jewish Canon: A Journey Through Language and Culture (New York: Free Press, 2000), 109-10.

17 On the Odessa gangsters' affinity with the Yiddish and Hebrew character of the 'ba' al guf' see Walenty Cukierman, "Isaak Babel"s Jewish Heroes and Their Yiddish Background," Yiddish 2, 4 (1977): 15-22.

18 Benjamin Harshav, Language in Time of Revolution (Berkeley: University of California Press, 1993), 33-39. Harshav has in mind mostly the secular polysystem in Modern Hebrew literature in the Land of Israel, but refers also to the situation in Soviet Russia and eastern Europe.

19 Leonid Katsis, for example, has found reverberations of Bialik in the poem "February" ("Февраль") by Babel"s fellow Odessite Eduard Bagritsky (“Одесская ветвь русско-еврейской литературы как 'PortJewish Literature'," in Русско-еврейская культура, под редакцией О.В. Будницкого [Москва: РОССПЭН, 2006], 115-26). 
20 On the thematic structuring of this story, see Zsuzsa Hetényi, "Лавка вечности -к мотивной структуре рассказа Гедали И. Бабеля,," Studia Slavica Academiae Scientarum Hungaricae 36 (1990): 187-92.

21 Khaim-Nakhman Bialik, Стихи и поэми [1922], new edition (Tel-Aviv: Dvir, 1964), 56; Hebrew original: 207, שירים (תל אביב: דביר, 1996.

22 Стихи и поэмы 13 שירים, 86.

23 See Hamutal Bar-Yosef, “Х.Н.Биалик и русская поэзия," Ariel (Russian edition) 3 (1990): 24-49; idem, "Romanticism and Decadence in the Literature of the Hebrew Revival," Comparative Literature 46, 2 (1994): 146-81.

24 See on the "hidden language" of German Jews, Sander Gilman, Jewish Self-Hatred: Anti-Semitism and the Hidden Language of the Jews (Baltimore: Johns Hopkins University Press, 1990).

25 Nurit Govrin, Alienation and Regeneration, trans. John Glucker (Tel Aviv: Ministry of Defense, 1989), 22; See Hamutal Bar-Yosef, "Reflections on Hebrew Literature in the Russian Context," Prooftexts 16 (1996): $127-49$.

26 Wisse, The Modern Jewish Canon, 87.

"פגישות עם יצחק בבל, " מאזניים 38, 2-1 (49-42: 27 (1973-1974).

28 "Рыцари цивилизации," Красный кавалерист 14 августа 1920. A similar angry description of a pogrom by White Cossacks in Komarów is “Недобитые убийцы” (Красный кавалерист 17 сентября 1920).

29 Лидия Миликова; Ирина Зюзина, “Из погромной хроники Гражданской войны," Еврейская Книгоноша 1 (2005): 34-39; И.Чериковер; И.Б.Шехтман, История погромного движения на Украине, 1917-21г2., 2 тт. (Berlin: Ostjüdisches historisches Archiv, 1923-32).

30 О.В.Будницкий, Российские евреи между красными и белыми (19171920) (Москва: РОССПЭН, 2005), 479-91; Steven Brown, “Communists and the Red Cavalry: The Political Education of the Konarmiia in the Russian Civil War, 1918-20," Slavonic and East European Review 73, 1 (1995): 82-99.

31 See, for example, Shimon Branfeld's three-volume litany from the Romans to Kmel'nitsky, ספר הדמעות (ברלין: אשכול, 1923).

32 "О резне," Стихи и поэмыь, 23; 152 שירים.

33 Bialik, Complete Poetic Works, ed. Israel Efros (New York: The Histadruth Ivrith of America, 1948), I, 128. 
Notes

34 I will return to modernist responses to Jewish catastrophe in chapter six.

35 Robert Alter, “The Jewish Voice," Commentary (October 1995): 41-42.

36 Zvi Gitelman, Jewish Nationality and Soviet Politics, 283-84.

37 Quoted in Ruth Karton-Blum, "Hebrew Communist Literature in Soviet Russia," in The Great Transition: The Recovery of the Lost Centers of Modern Hebrew Literature, ed. Glenda Abramson and Tudor Parfitt (Totowa NJ: Rowman \& Allanheld, 1985), 105.

38 Karton-Blum, "Hebrew Communist Literature in Soviet Russia," 103.

39 See Jehoshua Gilboa, A Language Silenced: The Suppression of Hebrew Literature and Culture in the Soviet Union (Rutherford, NJ: Fairleigh Dickinson University Press, 1982); Gitelman, Jewish Nationality and Soviet Politics; Karton-Blum, "Hebrew Communist Literature in Soviet Russia."

40 Quoted in Karton-Blum, "Hebrew Communist Literature in Soviet Russia," 106.

41 See discussion in chapter 6 and Rina Lapidus, Between Snow and Desert Heat: Russian Influences on Hebrew Literature, 1870-1970 (Cincinnati: Hebrew Union College Press, 2003), 134-54.

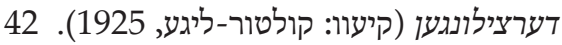

43 Slezkine, The Jewish Century, 135-36, 210, 242.

\section{Chapter Four}

1 Daniel Boyarin, Intertextuality and the Reading of Midrash (Bloomington: Indiana University Press, 1990), 57.

2 Seе И. Есаулов, “Этическое и эстетическое в рассказе Исаака Бабеля 'Пан Аполек'," Russian Literature 37, 1 (1995): 39-48; Zsuzsa Hetényi, “Библейские мотивы в Конармии Бабеля," Studia Slavica Academiae Scientarum Hungaricae 27 (1981): 229-40.

3 See Zsuzsa Hetényi, “Эскадронная дама, возведенная в мадонну: Амбивалентность в Конармии Исаака Бабеля," Studia Slavica Academiae Scientarum Hungaricae 31 (1985): 161-69; D. Tolczuk, “Crossing into Poland: On the Projection of Cultural Stereotypes in the Narration of Isaac Babel's 'The Church at Novogad,'” Polish Review 35, 3-4 (1990): 241-47; Judith D. Kornblatt, "At Home with Pani Eliza: Babel's Polish Encounters," in Polish Encounters, Russian Identity, ed. David L. Ransel and Bozena Shallcross (Bloomington: Indiana University Press, 2005), 160-71. 
4 This is something he has in common with another Pole, the French avant-garde poet Apollinaire, born Kostrowicki of a Polish mother and unknown father. See on this connection Maurice Friedberg, "Possible Interpretations for Babel's 'Pan Apolek'," in Depictions: Slavic Studies in the Narrative and Visual Arts in Honor of William A. Harkins, ed. Douglas M. Greenfield (Dana Point, CA: Ardis, 2000), 6-13. Robert Maguire traces Apolek's lineage to Appolinarius the fourth-century heretic ("Ekphrasis in Isaak Babel'," in Depictions, ed. Douglas M. Greenfield [Dana Point, CA: Ardis, 2000], 17).

5 The prototype of the blind musician who plays Heidelberg songs can be traced back to Windermeier, the blind musician from Túbingen in "A Concert in Katerinenstadt" (“Концерт в Катериненштадте," 1918).

6 The Nietzschean influence, quite strong in Russia at the beginning of the twentieth century, should not be discounted, but I feel it is fundamentally contrapuntal to Babel's concept of art and his aesthetics. See Robert Mann, The Dionysian Art of Isaac Babel' (Oakland, CA: Barbary Coast Books, 1994); Gregory Freidin, "Revolution as an Aesthetic: Nietzschean Motifs in the Reception of Isaac Babel' (19281932)," in Nietzsche and Soviet Culture: Ally and Adversary, ed. Bernice Glatzer Rosenthal (Cambridge: Cambridge University Press, 1994), 149-73.

7 РГАЛИ, ф. 1559, оп. 1, ед. хр. 13.

8 See Gareth Williams, "The Rhetoric of Revolution in Babel"s Konarmiia'," Russian Literature, 15, 3 (1984): 292; Nils Åke Nilsson, “Isaak Babel"s 'Perekhod cherez Zbruch',' Scando-Slavica 23 (1977): 63-71; Renate Lachmann, "Notizen zu I. Babel's 'Perechod čerez Zbruč,", in Voz'mi na radost': To Honour Jeanne van der Eng-Liedmeier, ed. W. Westeijn et al. (Amsterdam: Rodopi, 1980), 183-92; Wolf Schmid, "Das nicht erzählte Ereignis in Isaak Babel's 'Übergang über der Zbrucz'," Wiener Slawistischer Almanach 14 (1984): 117-38.

9 Marc Scheurs, Procedures of Montage in Isaak Babel's Red Cavalry (Amsterdam: Rodopi, 1989), 96-133.

10 Scheurs, Procedures of Montage, 102-03.

11 See Janet Tucker, "Skaz and Oral Usage as Satirical Devices in Isaak Babel"s Red Cavalry," in Against the Grain: Parody, Satire, and Intertextuality in Russian Literature, ed. Janet G. Tucker (Bloomington: Slavica, 2002), 101-12.

12 К.Н.Батюшков, Сочинения, ред. А.Д.Благого (Москва: Academia, 1934), 158-59. 
13 Charles Rougle, "Introduction: Isaac Babel and his Odyssey of War and Revolution," in Red Cavalry: A Critical Companion, ed. Charles Rougle (Evanston: Northwestern University Press/AATSEEL, 1996), 20.

14 Schreurs, Procedures of Montage in Isaak Babel's Red Cavalry, 175-76.

15 Efraim Sicher, Jews in Russian Literature: Writers and Artists Between Hope and Apostasy (Cambridge: Cambridge University Press, 1995), 55-57; Maurice Friedberg, "Yiddish Folklore Motifs in Isaac Babel"s Konarmiia," in American Contributions to the 8th International Congress of Slavists, Zagreb-Liubliana, 1978, ed. V. Terras (Columbus, OH: Slavica, 1978), II, 192-203.

16 Бабель, Закат (Москва: Круг, 1928), 95-96.

17 The reference is to the biblical story of creation and the divine division of day and night, which the midrash on the response of Moses to the revolt of Korach cites as an argument for the established divinely ordained order (Midrash Tankhuma, $\mathrm{P}^{\prime}$ Korakh, 5).

18 Zholkovsky notes that the Hebrew quotations serve as a counterpoint to the grotesque love theme in the play, leading up to the mock wedding feast, in a way reminiscent of Sholom Aleichem ("Роман с гонораром").

19 Sunset was revived in the Soviet Union only in 1988. Previous attempts to stage it by Jewish dramatic groups met with opposition to its "nationalistic" (i.e. Jewish) content, for example in 1966 (communication to the present author by Hersh Levinson, a former actor of the Moscow Jewish Theatre, 6 August 1976). The play was, however, published in book form and included in Babel"s selected works.

\section{Chapter Five}

1 Emma Lieber argues that Babel' gives a highly impressionistic and inaccurate presentation of Gogol"s "sunny" Ukraine ("Where is the Sweet Revolution?': A Reconsideration of Gogol and Babel," Slavic and East European Journal 53, 1 [Spring 2009]: 1-18).

2 Chekhov and Tolstoy quoted in Z. Rukalski, "Maupassant and Chekhov: Similarities," Canadian Slavonic Papers 11, 3 (1969): 346.

3 “Автобиография," Избранное (Москва: Издательство художественной дитературы, 1966), 23.

4 Maurice Parijanine, "Introduction," in Isaac Babel, Cavalerie rouge (Paris: Editions Rieder, 1928), 9-10. 
5 Lily Denis, "Permanence de Maupassant en Russie," Europe 482 (June 1969): 163-72. See Emile Haumant, La culture française en Russie (17001900), $2^{\text {nd }}$ revised edition (Paris: Libraire Hachette, 1913), 480, 487, 521.

6 On Tolstoy's misreading of Maupassant and the Tolstoy-Maupassant opposition in Babel"s own story, see Alexander Zholkovsky, "How a Russian Maupassant Was Made in Odessa and Yasnaya Polyana: Isaak Babel' and the Tolstoy Legacy," Slavic Review 53, 3 (1994): 683-93; А.К.Жолковский и М.Б.Ямпольский, Бабель/Babel', 30-56 ; reprinted in Жолковский, Полтора рассказа Бабеля, 19-41.

7 The three-volume collection of stories by Maupassant which Babel' edited in 1926-1927 included three of his own translations, "L'Aveu," "Idylle" and "Le mal d'André"; see bibliography above. Babel"s translations are reproduced in Е.Погорельская, "И.Э.Бабельредактор и переводчик Ги де Мопассана (материалы к творческой биографии писателя)," Вопросы литературы 4 (2005): 323-51. Babel' also received an advance in 1930 for a film version of Boule de Suif (directed by M. Romm, 1934) but did not complete the assignment (М.Макотинский, "Умение слушать," Воспоминания о Бабеле, 105).

8 Babel' quoted in Ольник, “Писатель И.Бабель в Смене," Смена 17-18 (1932): 25.

9 Lev Tolstoy, "Guy de Maupassant," in Documents of Modern Literary Realism, ed. George J. Becker (Princeton, NJ: Princeton University Press, 1963), 422-23.

10 "Isaac Babel"s Story 'Guy de Maupassant'," in Studies in Twentieth Century Russian Prose, ed. N.Å. Nilsson (Stockholm: Almqvist \& Wiksell, 1982), 212-27.

11 David Magarshack, Chekhov: A Life (London: Faber, 1952), 111.

12 Lev Slavin quoted in Е.Погорельская, “И.Э.Бабель-редактор и переводчик Ги де Мопассана": 325.

13 Guy de Maupassant, "Le roman," Oeuvres complètes (Paris: Louis Conard, 1909), IV, xxiv-xxv.

14 "Money, Translation, and Subjectivity in Isaak Babel"s 'Guy de Maupassant'," Yearbook of General and Comparative Literature 50 (20022003): 161-68.

15 The model for Kazantsev would appear to be Kudriavtsev, a fellow contributor to Gor'ky's Novaia zhizn' in 1918, who was the proud owner of a rare edition of Don Quixote (Babel', letter to Gor'ky, June 25, 1925, Собрание сочинений, IV, 31-32). 
16 "Miss Harriet" is the one story mentioned in "Guy de Maupassant" that was not included in Babel"s three-volume edition of Maupassant's stories.

17 Charles Rougle takes this to be opting for a more Nietzschean outlook ("Art and the Artist in Babel"s 'Guy de Maupassant'," Russian Review 48 [1989]: 171-80).

18 Maupassant uses "rigolade" (having fun, joking) which Babel' translates "потеха" (festivity, fun; Babel', Собрание сочинений, III, 41718). On similar stylistic and factual changes in Babel"s translations of Maupassant, see Е.Погорельская, “И.Э.Бабель-редактор и переводчик Ги де Мопассана. For a comparison of Babel"s translation of "The Confession" with previous Russian versions, see idem, "Рассказ Ги де Мопассана 'Признание' в переводе Исаака Бабеля," Тургеневские чтения 5 (Москва: Книжница, 2011), 332-50.

19 Babel' quotes from comments of Dr. Blanche (Maynial, La vie et l'oeuvre de Guy de Maupassant [Paris: Societé de Mercure de France, 1907], 282), but typically gives his own version of Maupassant's life. Maynial's book had been translated into Russian in 1910. Maynial takes the phrase Monsieur Maupassant "est en train de s'animaliser" from Edmond de Goncourt's diary for January 1893, but asserts that it is a true report of what Dr Blanche said.

20 Alexander Zholkovsky, "How a Russian Maupassant Was Made in Odessa and Yasnaya Polyana," 679.

21 One of Babel"s last appearances in print was a plea for republication of Tolstoy ("Литературные мечтания," Аитературная газета, 31 декабря 1938, 5). In the period 1918-1941, Tolstoy actually ranks lower than Dostoevsky in the number of copies published of their works (Maurice Friedberg, Russian Classics in Soviet Jackets [New York: Columbia University Press, 1962], 187-89). Publication of Tolstoy's Complete Works was authorized in August 1939.

22 J. Lavrin, "Chekhov and Maupassant," Slavonic Review 5, 13 (1926): 1-24.

23 H. E. Bates, The Modern Short Story, 2nd edition (London: Michael Joseph, 1972), 72-94.

24 I. Ehrenburg, in Babel, You Must Know Everything (New York: Farrar \& Straus, 1969), 231.

25 On the prostitution theme see A.К.Жолковский и М.Б.Ямпольский, Бабель/Babel', 317-68.

26 А.Нюренберг, "Встречи с Бабелем," Воспоминания о Бабеле, 195-96. This conversation is supposed to have taken place in Moscow in 1922, 
a suspiciously early date, when Babel' was working on a newspaper in the Georgian capital, Tbilisi, and had not yet moved to Moscow.

27 For example, A. Lezhnev spoke of the impression that Babel's stories were translated from the French and concluded that Babel' learnt story structure from Maupassant, but sentence structure from Flaubert (A. Лежнев, Современники: Литературно-критические очерки [Москва: Круг, 1927]), 127-128; А. Лежнев, Литературные будни [Москва: Федерация, 1929], 265). In the West, too, Maupassant's influence is often acknowledged (for example, R. Poggioli, The Phoenix and the Spider [Cambridge, MA: Harvard University Press, 1957], 229-38; A. Yarmolinsky, The Russian Literary Imagination [New York: Funk \& Wagnalls, 1969], 131-85).

28 Babel' cited in Ольник, “Писатель И.Бабель в Смене,” 25.

29 К.Паустовский, Повесть о жизни (Москва: Советская Россия, 1966), II, 530.

30 See on the organizational function of color imagery, Р.Назарян, “Мопассановские новеллы И.Бабеля: К вопросу ассоциативноконтекстовой колористичности," Труды Самаркандского университета: Вопрось теории и истории литературь 320 (1977): 5162. See also Nils Åke Nilsson on the imagery and structure of "Guy de Maupassant," "Isaac Babel's Story 'Guy de Maupassant," , 212-27; and Nilsson, "Tolstoj-Čechov-Babel': 'Shortness' and 'Syntax' in the Russian Short Story," Scando-Slavica 28 (1982): 91-107.

31 И.Смирин, “У истоков военной темы в творчестве И.Бабеля: И.Бабель и Гастон Видаль," Русская литература 1 (1967): 203-04. See also C. D. Luck, Figures of War: Two Cycles of Stories by Isaak Babel' (Oxford: Oxon Publishers for Essays in Poetics, 1992).

32 Аитературное наследство 70 (1963): 44.

33 А. Сейфулдина, Собрание сочинений (Москва: Художественная питература, 1969), IV, 291. The reference may well be to the 1918 piece "Evening," which appeared in Gor'ky's Novaia zhizn'.

34 Maynial, La vie et l'oeuvre de Guy de Maupassant, 7.

35 See Patricia Carden, The Art of Isaac Babel (Ithaca: Cornell University Press, 1972), 207-09.

36 According to Lev Nikulin in his Годь нашей жизни (Москва: Московский рабочий, 1966), 216-29.

37 Е.Погорельская, “'В дыму и золоте парижского вечера...': Исторический и литературный контекст рассказа И.Бабеля 'У лица Данте,'" Bonросы литературы 1 (2010): 277-302. 
38 Babel' quoted in К.Паустовский, Время больших ожиданий (Москва: Советский писатель, 1960), 128.

\section{Chapter Six}

1 Ю.М.Лотман, Структура художественного текста (Providence, RI: Brown University Press, 1971), 265-66. On binary opposition in Russian cultural modeling systems seе Вячеслав В. Иванов, Славянские языковые моделирующие системы: Аревний период (Москва: Наука, 1965), 156-75; see also Efraim Sicher, “Binary Oppositions and Spatial Representation: Towards an Applied Semiotics," Semiotica 60, 3-4 (1986): 211-24.

2 Лотман, Структура художественного текста, 278-79.

3 Lotman, Universe of the Mind: A Semiotic Theory of Culture, trans. Ann Shukman (Bloomington: Indiana University Press, 1990), 131-42. For a summary of Lotman's theory of the modeling of fictional space and its philosophical context see Katharina Hansen-Löve, The Evolution of Space in Russian Literature: A Spatial Reading of 19th and 20th Century Narrative Literature (Amsterdam: Rodopi 1994), 29-45. For a narrative text model of space in Red Cavalry, see Jan van Baak, The Place of Space in Narration: A Semiotic Approach to the Problem of Literary Space, with an Analysis of the Role of Space in I. E. Babel's Konarmiia (Amsterdam: Rodopi, 1983).

4 Gary Rosenshield, The Ridiculous Jew: The Exploitation and Transformation of a Stereotype in Gogol, Turgenev, and Dostoevsky (Stanford: Stanford University Press, 2008), 200-04.

5 Mirja Lecke has pointed out that in Red Cavalry, the Ukrainian perspective is almost entirely absent, while the Polish view is mainly stereotyped from a Russian cultural point of view ("The Deconstruction of Galicia in Babel"s Red Cavalry," in Krajina bez vlastností: Literatura a Střední Evropa / Landschaft ohne Eigenschaften: Literatur und Mitteleuropa: Festschrift für Peter Demetz zum 85. Geburtstag, ed. Petr Bílek and Tomáš Dimter [Prague, 2010], 118-25).

6 See translator's note, Complete Works, 231.

7 On the "dirty ethics" of "My First Goose," see Val Vinokur, The Trace of Judaism: Dostoevsky, Babel', Mandelstam, Levinas (Evanston, IL: Northwestern University Press, 2008), 60-92.

8 Carol J. Avins, unpublished paper, "Babel"s First Goose, the Third International, and the Language of Lenin," annual meeting of the AAASS, 4 November 2005. On the political and ideological context of 
the Soviet-Polish War see Norman Davies, White Eagle, Red Star: The Polish-Soviet War, 1919-20 (London: Macdonald, 1972).

9 Joe Andrew believes this indicates homoeroticism, which would suggest a rather different interpretation of the ending ("'Spoil the Purest of Ladies': Male and Female in Isaac Babel"s Konarmiia." Essays in Poetics 14, 2 [1989]: 1-27).

10 Leon Trotsky, My Life (Harmondsworth: Penguin, 1975), 376.

11 See Gabriella Safran, Rewriting the Jew: Assimilation Narratives in the Russian Empire (Stanford: Stanford University Press, 2000).

12 Rufus W. Matthewson, The Positive Hero in Russian Literature. 2nd edition (Stanford: Stanford University Press, 1975), 179-82.

13 For a comparison of Red Cavalry with contemporary depictions of the revolution and civil war, see Robert Maguire, Red Virgin Soil: Soviet Literature in the 1920s (Princeton: Princeton University Press, 1968), 32748; В.Перцов, "Какая была погода в эпоху гражданской войны?" Новый Леф 7 (1927): 36-45.

14 Victor Peppard, "The Problem of Revolutionary Violence in Isaac Babel"s Stories," in Times of Trouble: Violence in Russian Literature and Culture, ed. Marcus C. Levitt and Tatyana Novikov (Madison: University of Wisconsin Press, 2007), 163-73. See also H. Marder, "The Revolutionary Art of Babel," Novel 7 (1973-1974): 54-61; Peter Stine, "Isaac Babel and Violence," Modern Fiction Studies 30, 2 (1984): 237-55; Frank O'Connor, "The Romanticism of Violence," The Lonely Voice: A Study of the Short Story (New York: Bantam, 1963), 187-201.

15 А.Воронский, “И. Бабель," Аитературные типь (Москва: Круг, 1925), 102-05.

16 Translated by Frank Miller as "Armored Train 14-69," in Evgeny Zamiatin, Islanders, and Vsevolod Ivanov, Armored Train 14-69 (Ann Arbor: Trilogy Publishers, 1978), 48-109.

17 Разгром (Ленинград: Прибой, 1928), 56-57.

18 The Rout (Moscow: Foreign Languages Publishing House, 1957), 50.

19 Ibid, 110-11.

20 Ibid, 112-17.

21 Ibid, 147-48.

22 Mathewson, The Positive Hero in Russian Literature, 192.

23 Ibid, 198-99. 
24 See Michael S. Gorham, "Writers at the Front: Language of State in the Civil War Narratives of Isaac Babel' and Dmitri Furmanov," in The Enigma of Isaac Babel: Biography, History, Context, ed. Gregory Freidin (Stanford: Stanford University Press, 2009), 100-15.

25 Patricia Carden, The Art of Isaac Babel, 127-28.

26 М.Горький, “Ответ С.Буденному,” Правда 27 ноября 1928, 5.

27 Bulgakov, The White Guard, trans. Michael Glenny (London: Collins Harvill, 1971), 128-29.

28 Ibid, 159-60.

29 Sergei Eisenstein, Selected Works, Volume 1: Writings, 1922-1934, ed. R. Taylor (London: British Film Institute / Bloomington: Indiana University Press, 1988), 95, 98; see Marc Schreurs, Procedures of Montage in Isaak Babel's Red Cavalry (Amsterdam: Rodopi, 1989).

30 Белая гвардия, Театральный роман, Мастер и Маргарита (Денинград Художественная литература, 1978), 231-32.

31 The White Guard, 253.

ישראל ראַבאָן, די גאַס (ווארשע: ל. גאָלנפּאַרב, 1928), 113. 32

33 Israel Rabon, The Street, trans. Leonard Wolf (New York: Schocken, 1985), 72 (translation slightly corrected).

34 Peter Kenez, "The Pogroms of 1919-1921," in Pogroms: Anti-Jewish Violence in Modern Russian History, ed. John D. Klier and Shlomo Lambroza (Cambridge: Cambridge University Press, 1992). 291-313. For historical documentation of atrocities committed against Jews, see О.В.Будницкий, Российские евреи между красньми и бельми (19171920) (Москва: РОССПЭН, 2005); И.Чериковер, И.Б.Шехтман, История погромного движения на Украине, 1917-21г2. (Berlin: Ostjüdisches historisches Archiv, 1923-1932).

געזאמלטע ווערק (ירושלים: הוצאת מאגנס, 1979), באַנד א', 30535.

אורי צבי גרינבערג, "אין מלכות פון צלם, “ געזאַמלטע ווערק, באַנד ב', 472-457. 36 First published in the Yiddish journal Albatross [Berlin], 3-4 (1923): 15-24. See Roskies, Against the Apocalypse, 267-74.

אורי צבי גרינבערג, ”אורי צבי פארן צלם, “ געזאמלטע ווערק, באַנד ב', 432. 37 First published in the Yiddish journal Albatross [Warsaw] 2 (1922): 3-4; reproduced in Roskies, Against the Apocalypse, 265.

38 See Mikhail Krutikov, Yiddish Fiction and the Crisis of Modernity, 19051914 (Stanford: Stanford University Press, 2001). 
ל. שֵַפּירא, די יודישע מלוכה און אַנדערע זאַַען (ניו-יאָרק: אידיש לעבען, 1929), 81-82. 39

40 "White Challah," The Jewish Government and Other Stories, trans. Curt Leviant (New York: Twayne, 1971), 64.

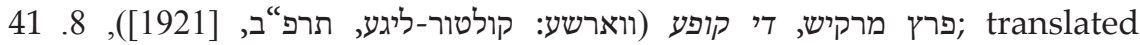
as "The Mound" in The Literature of Destruction: Jewish Responses to Catastrophe, ed. David G. Roskies (Philadelphia: Jewish Publication Society of America, 1988), 364. Another, slightly different, Yiddish edition appeared in Kiev, published by the Kultur-Lige, in 1922, with a cover design by Iosif Chaikov that recalls El Lissitzsky's famous "Beat the Whites with the Red Wedge" poster, derived from the anti-Semitic slogan "Beat the Jews, Save Russia!"

42 Seth Wolitz, "A Yiddish Modernist Dirge: Di Kupe of Peretz Markish," Modern Jewish Studies Annual VI (1987), 56-72; Roy Greenwald, "Pogrom and Avant-Garde: Peretz Markish's Di kupe," Jewish Social Studies 16, 3 (Spring/Summer 2010): 65-84. See also Roskies, Against the Apocalypse.

43 Amelia Glaser, "The End of the Bazaar: Revolutionary Eschatology in Isaac Babel"s Konarmiia and Peretz Markish's Di Kupe," Jews in Russia and Eastern Europe 2 [53] (2004): 5-32.

44 For a comparison of Khaim Hazaz's novel with Red Cavalry see א“ב יפה, "בין יצחק באבל לחיים הזז," בתוך: חיים הזז: מבחר מאמרי ביקורת, ערך הלל ברזל (תל אביב: עם עובד, 1978), 318-316.

חיים הזז, "מזה ומזה," התקופה 21 (1923-24): 11. 45

46 Murav, Music from a Speeding Train: Jewish Literature in Post-Revolution Russia (Stanford: Stanford University Press, 2011), 26.

47 Music from a Speeding Train, 29, 33, 34.

48 An English translation has been published as "Civil War," trans. Seth Wolitz, in Ashes out of Hope: Fiction by Soviet Yiddish Writers, ed. Irving Howe and Eliezer Greenberg (New York: Schocken, 1977), 84-123.

אברהם נוברשטרן, קסם הדמדומים: אפוקליפסה ומשיחיות בספרות יידיש 49 (ירושלים: מאגנס, תשס"ג [2003]).

50 See for example, Myler Wilkinson, "Appendix: Hemingway and Babel'," Hemingway and Turgenev: The Nature of Literary Influence (Greenwood, CN: UMI Research Press, 1986); Б.Гиленсон, "Бабель-Хемингуэй," Сюжет и время: Сборник трудов (Коломна, 1991), 156-59; Max Apple, "History and Case History in Red Cavalry and Day of the Locusts," Nathanael West: The Cheaters and the Cheated, ed. D. Madden (Deland, FL: Everett \& Edwards, 1973), 235-47. 


\section{Chapter Seven}

1 Е.Каракина, По следам юго-запада, 155.

2 On Babel"s collectivization stories and their place in his work, see И. Смирин, "И. Бабель в работе над книгой о коллективизации," Филологический сборник 6-7 (1967): 104-09; С. Поварцов, "Мир, видимый через человека: Материалы к творческой биографии Исаака Бабеля," Воспоминания о Бабеле, 326-28; В.Ковский, “Судьба текстов в контексте судьбы," Вопросы литературы 1 (1995): 47-51; א. אהרוני, "יצחק בבל והקולקטיביזציה, "שבות 3 (1975): 125-123.

3 Lonely Years, 145.

4 Lonely Years, 151, 158.

5 Letter of 16 February 1930 sent from Kiev, Lonely Years, 136.

6 "Extremely interesting" (German); Письма другу: Из архива И.Я.Аивщица, сост. Е.Погорельская (Москва: Государственный дитературный музей / Три квадрата, 2007), 73.

7 М. Макотинский, "Умение слушать," Воспоминания о Бабеле, 105; in the uncensored version, published posthumously in Hebrew, Makotinsky claims that Babel' refused a large fee for a commission to write about collectivization and went to the villages in the Kiev region on his own impetus:

"מזיכרונותיי על יצחק בבל," בתוך: יצחק בבל, להמשך אל השמש, תרגם אברהם

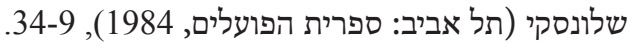

8 Roman eines Romans: Moskauer Tagebuch (Kőln: Verlag Wissenscraft und Politik, 1962), 293-97.

9 Letters from a Cossack settlement, Prishibskaia, 13 December and 19 December 1933, Lonely Years, 245-46, 247.

10 Letter of 20 January 1934, from Gorlovka, Lonely Years, 249.

11 Letter from Stalino, 9 December 1936, Lonely Years, 296.

12 See letters of 19 February and 15 March 1931, Lonely Years, 161-62, 164-65. The Jewish collective farms were later liquidated; see Jonathan DekelChen, Farming the Red Land: Jewish Agricultural Colonization and Local Soviet Power, 1924-1941 (New Haven: YaleUniversity Press, 2005). Seealso אסקאר סטרעליץ, דער באלשעוויסטישער פרילינג: פארצייכענונגען פון קאלינינדארפער ראיאן (מאָסקווע: דער עמעס, 1930).

13 Letter of 12 September 1935, Lonely Years, 288.

14 СССР на стройке 3 (1936). Layout and text by Babel'. 
15 СССР на стройке 4 (1937).

16 СССР на стройке 6 (1939).

17 Robert Conquest, Harvest of Sorrow: Soviet Collectivization and the TerrorFamine (New York: Oxford University Press, 1986), 308-21.

18 Victor Kravchenko, I Chose Freedom: The Personal and Political Life of a Soviet Official (New York: Scribner's Sons, 1946), 91.

19 Conquest, Harvest of Sorrow, 115-16.

20 See Carol Avins, "Isaak Babel"s Tales of Collectivization: Rites of Transition in the New Soviet Village," Slavic Review 64, 3 (2005): 560-79. Avins notes, however, that in setting the story at Shrovetide (maslenitsa), Babel' may not have been aware that in the Orthodox calendar weddings were not permitted at this time, which, significantly, is marked by forgiveness and reconciliation (566-67).

21 Avins, “Isaak Babel”s Tales of Collectivization," 567-68.

22 Conquest, Harvest of Sorrow, 117.

23 Kravchenko, I Chose Freedom, 104.

24 Conquest, Harvest of Sorrow, 118-27.

25 Avins, “Isaak Babel”s Tales of Collectivization," 571-72.

26 Kravchenko, I Chose Freedom, 106.

27 Поднятая цеелина, 2-е изд. (Москва: Федерация, 1932), кн. 1, 65.

28 The Soil Upturned: A Novel [no translator given] (Moscow: Co-Operative Publishing Society of Foreign Workers in the U.S.S.R., 1934)

29 Quoted in Conquest, Harvest of Sorrow, 234.

30 Victor Kravchenko, I Chose Freedom, 107-08.

31 Vasily Grossman, Forever Flowing, trans. Thomas P. Whitney (New York: Harper \& Row, 1972), 143.

32 Conquest, Harvest of Sorrow, 146-63. See Lynne Viola, Peasant Rebels under Stalin: Collectivization and the Culture of Peasant Resistance (New York: Oxford University Press, 1996).

33 Поднятая изелина, кн. 1, 338-39; Soil Upturned, 438-39.

34 Conquest, Harvest of Sorrow, 217-73. See also R. W. Davies, The Soviet Collective Farm, 1929-30 (London: Macmillan, 1980).

35 Kravchenko, I Chose Freedom, 110-131. 
36 Grossman, Forever Flowing, 155.

37 See Avins, "Isaak Babel"s Tales of Collectivization," 572-73.

38 С. Третьяков, “Построимся в бригады”, Аитературная газета, 6 января 1930, 1; cited in Avins, "Isaak Babel"s Tales of Collectivization," 566.

39 Kopelev, The Education of a True Believer, trans. Gary Kern (New York: Harper \& Row, 1980), 235.

$40 \mathrm{Kopelev,} \mathrm{The} \mathrm{Education} \mathrm{of} \mathrm{a} \mathrm{True} \mathrm{Believer,} 265$.

41 See Czeslaw Andruszko, "Пиатонов и Бабель: Новые Дон Кихоты," Studia Rossica Poznaniensia 26 (1995): 39-49.

42 See chapter one and Avins, "Isaak Babel"s Tales of Collectivization," $572,578$.

43 Avins, "Isaak Babel"s Tales of Collectivization," 563. Avins mentions several essays on collectivization that appeared in Novyi mir in 19301932 which contrast with the starker, more reserved tones of Babel's story.

44 В.П.Полонский, “Из дневника 1931 года”, Воспоминания о Бабеле. 198-99.

45 Ibid, 198.

46 И.Эренбург, Аюди, годы, жизнь: Воспоминания (Москва: Советский писатель, 1990), I, 471; Б.Суварин, “Последние разговоры с Бабелем", Континент 23 (1980): 343-378. See on Babel"s frank comments, Поварцов, "Арест Бабеля"; А.Грибанов, “Борис НиколаевскийИсаак Бабель-Борис Суварин и некоторые проблемы эмигрантской журналистики", Тыняновский сборник, Вып. 11: Девятые Тыняновские чтения (Москва: ОГИ, 2002), 453-67. 


\section{INDEX}

Academia (publishing house) 73, 243

Akhad Ha'am (Asher Ginzburg) 110, 112, 125

Akhmatova, Anna 86, 97, 101

Akiva, Rabbi 255n35

Aleksandrov, Grigory 78, 240

Alexander I 138

All Quiet on the Western Front (Remarque) 195

Allenby, Field Marshal Edmund 106

"Alone" (Bialik) 118

Alter, Robert 123

Al'tman, Natan 126

Amsterdam 141

anti-Cosmopolitan campaign 24, 266n124

anti-Semitism 22, 24, 43, 49, 51, 52, 88, 110, 115, 120, 122, 149, 173, 197, 221, 265n120, 267n135

Apanasenko, Iosif 43, 188

Apollinaire (Kostrowicki), Guillaume 277n4

Apollo 130, 131

Armored Train 14-69 (Vsevolod Ivanov) 183

Aronson, Boris 126

Arye Ba'al Guf (Bialik) 113

Asch, Sholom 113, 199

Ashdod 18

assimilation 91, 114, 115

Auto-Emancipation (Pinsker) 110

Avins, Carol 213, 215, 287n20, 288n43

Azef, Evno 55, 242

Babel', Emmanuel 13

Babel'(Gronfein), Evgenia (Zhenia) 13, 54-57, 256n8, 260n57 
Babel'(Shvekhvel'), Faige (Fenia) 13, 29

Babel', Isaak

- arrest and imprisonment of 74-80

- as Jewish cultural icon 12

- and the literary canon 90, 112, 129

- childhood of 13, 29-32, 48, 49, 127, 141, 148, 157, 173

- execution of 79-80

- in the First Horse Army 39-44

- literary career of 32-74

- in Paris 54-57

- on the Rumanian front 35, 195

- rehabilitation of $80-84$

- silence of $61-72$

Works: "About a Georgian, a Kerensky Note, and a General's

Daughter" 150; "About Horses" 164; "After the Battle" 191; "And There Were Nine" 41, 42, 178-180; "Argamak" 44, 181; "At Bat'ko Makhno's" 62, 206, 207, 226; “At St. Valentine's Church" 133, 134, 172, 195; "Autobiography" 13, 29, 31, 32, 34, 35, 66, 164, 229; "Awakening" 31, 48, 53, 157, 181, 220; "The Beginning" 34; Benia Krik 37, 38; "Beresteczko" 193, 227; "Betrayal" 88; "By the Church of the Holy Trinity" 69; "Cemetery in Kozin" 42, 43, 121, 122, 143; The Chekists 60, 150; "Childhood. At Grandmother's" 31, 49, 52, 156; "The Chinaman" 35, 227; "The Church in Novograd" 131, 134, 138, 172; "Commander of the Second Brigade" 188; "A Concert in Katerinenstadt" 277n5; "Crossing the Zbrucz" 42, 121, 135, 137, 171, 175, 193, 194, 198; "The Death of Dolgushov"44, 190; “The Death of Trunov" (draft) 142; “Demidowka” (draft) 143; "Di Grasso" 48, 127, 152, 168; "El'ia Isaakovich and Margarita Prokof'evna" 34, 100; “The End of the Old Folk's Home" 37, 97, 220; "Esther's Ring" (ascribed) 36; Etchings 35; “Evening" (1918) 281n33; "Evening" (Red Cavalry story) 188; "Evening at the Empress's" 49, 148; "The Father" 100; "First Love" 49, 52, 113; "Froim Grach" 35, 37, 225, 263n102; “Gapa Guzhva" 209, 212, 220, 222, 224, 226; "Gedali" 62, 85, 115, 117, 166, 173, 202; "Grishchuk" 42; "Guy de Maupassant" 27, 48, 72, 154-156, 158, 161-165, 168, 243, 268n11, 280n16, 281n30; "How It Was Done in Odessa" 38, 53, 96, 103, 108, 147; "In the Basement" 29, 40, 141; “Inspiration" 36; "Italian 
Sunshine" 161, 188; The Jewess 60, 82, 182, 227; "The Journey" 35, 48, 49, 148, 149, 193, 225, 227; "Justice in Parenthesis" 36, 94, 100, 104, 255n1; "Karl-Yankel” 38, 65, 126-128, 168, 182; “The King" 36, 96, 100, 103; “The Kiss" 27, 44; Kolia Topuz 69; "Kolyvushka" 214, 217, 220, 222; “Konkin" 122; “Leaves from My Notebook" 34; “The Letter" 88; "Line and Color" 36, 123, 157; "Liubka the Cossack" 100, 144, 212, 272n59; "Mamma, Rimma, and Alla" 34, 225; Maria 60, 150; "My First Fee" 36, 89, 161, 163, 263n102; "My First Goose" 173, 176, 186, 198, 282n7; No. 4, Old Square 74; "Notes from Odessa" 16, 97, 105, 152; “Odessa” 16, 35, 95, 97, 98, 151, 153, 157, 158, 168; Odessa stories 36, 38, 48, 63, 99, 101, 144, 157, 229, 235, 241, 272n59; "Oil" 61, 208, 224; "Old Shloime" 32; On the Field of Honor 39, 166, 195; Petersburg 1918 35; "Pan Apolek" 130, 131, 139, 273n59, 277n4; "Prishchepa" 166; "The Quaker" 166; "The Rebbe" 92, 118, 142, 177, 187; “The Rebbe's Son" 42, 44, 114, 122, 123, 141; Red Cavalry 26-28, 36, 37, 39, 42-48, 50, 53, 61-64, 69, 76, 77, 81, 82, 85, 88, 92, 94, 95, 101, 104, 113-115, 118, 120-123, 125, 130, 133, 137-143, 155, 161, 170, 171, 174, 179-184, 186-188, 191-194, 197, 202, 204, 206-208, 215, 221, 226, 228, 229, 231, 232, 235, 237, 241, 248-251, 258n35, 282n3n5, 283n13, 285n44; "The Road to Brody" 139, 178, 193; "Rue Dante" 56, 167; "At St. Valentine's Church" 133, 134, 172, 195; "Salt" 88, 101, 180; "Sashka the Christ" 140; "Shabos Nakhamu" 92, 93, 105, 106; "The Sin of Jesus" 20, 139; "Squadron Commander Trunov" 142, 179, 190; "Story of a Horse" 46, 167; Story of My Dovecote 29, 48, 49, 64, 83; "Story of my Dovecote" 49, 51, 52, 113, 114, 255; "Sulak" 222, 224; Sunset 19, 60, 94, 113, 144, 147, 278n19, "Sunset" 272n59; "SS Cow-Wheat" 220; "Tale of a Hardworking Woman" 207, 227; "Three O'Clock in the Afternoon" 33; "Through the Fanlight" 34, 207, 225, 226; “The Trial” 56, 167; “The Two Ivans" 192; Velikaia Krinitsa 28, 60, 61, 65, 69, 208-227; “The Widow" 192; "You Missed the Boat, Captain!" 47

Babel', Lydia 14, 58, 74

Babel' (Shaposhnikov), Meri 54

Babel, Nathalie 29, 35, 57

Baginen 125, 126

Bagritsky (Dziuba), Eduard 18, 23, 25, 70, 72, 76, 98, 101, 103, 127, 194, $242,244,246,254 \mathrm{n} 34,274 \mathrm{n} 19$ 
Index

Bakhtin, Mikhail 87

Balfour Declaration 106, 111

Bang, Herman 123

Barbusse, Henri 106, 195

Baron, S. W. 121

Barzilai, Yosef 124

Bates, H. E. 162

Batiushkov, K. N. 137, 138

Bat-Miriam, Yocheved 124

Baudelaire, Charles 166

Baumgarten, Murray 85

"Before the Book-Cupboard" (Bialik) 116, 122

Beilis trial 32, 33

Belaia Tserkov' (Bila Tserkva) 29, 40

Belaia, Galina 82, 267n135

Belarus 121

Bellow, Saul 11, 15

Ben-Ami (I. M. Rabinovich) 110

Bentovim, Puah 120

Berdichevsky, Mikhah Yosef 119, 123, 125

Bergelson, Dovid 89, 205, 206, 243, 260n62

Bergson, Henri 86, 268n8

Beriia, Lavrentii 75, 78, 265n120

Berkowitz, I. D. 119

Berlin 112, 125, 210

Bezhin Meadow (Eisenstein) 70, 224

Bialik, Khaim Nakhman 26, 108, 110-122, 124, 125, 127, 128, 181, 198, 199, 201, 274n19

Bliokh, Yakov 240

Blok, Alexander 97, 105, 124, 140, 195

Boccacio, Giovanni 139

Boyarin, Daniel 129

Bread (Kirshon) 224

"Bread" (Svetlov) 22

Breakdown and Bereavement (Brenner) 119, 272n55

Brenner, Yosef Khaim 112, 119, 120

Breshit 113, 124, 125, 202 
Brighton Beach 18

Briusov, Valery 116

Bronze Horseman (Pushkin) 194

Brothers (Markish) 205, 206

Brueghel, Peter 220

Brussels 55

Buber, Martin 142

Budenny, Semyon 27, 39, 40, 43-47, 61-63, 120, 121, 135, 143, 150, 188, 194, 258n34, 259n43, 261n66

Bukharin, Nikolai 211, 217

Bulgakov, Mikhail 20, 68, 82, 84, 192

Bund 111, 120

Chagall, Marc 95, 122, 134, 140, 195

Chaikov, Iosif 125, 126, 285n41

Chapaev (Furmanov) 27, 46, 187, 192, 240

Cheka 35, 49, 124, 149, 156, 204, 226, 257n15, 260n63

Chekhov, Anton 27, 32, 101, 152, 153, 155, 158, 161-164, 207, 278n2

Chernikhovsky, Saul 198

Chernobyl (dynasty) 142

Cherry Orchard (Chekhov) 52, 101

Christianity 24, 25

Chukovsky, Kornei (Nikolai Korneychukov) 21

Civil War 14, 16, 23, 27, 37, 46, 48, 60, 69, 75, 82, 105, 113, 115, 140, 150, 170, 182, 194, 195, 198, 205, 206

“Civil War" (Bergelson) 206, 207, 218, 235, 237, 240, 283n13

Claudel, Paul 152, 153

Cloud in Pants (Maiakovsky) 195

"Coco" (Maupassant) 166

collectivization 24 , 28, 60, 61, 65, 69, 77, 78, 83, 207-212, 214, 215, 217-221, $223,224,226,227,238,239,241,245,286 n 2 n 7,288 n 43$

Commissars (Libedinsky) 186

communism 11, 12, 17, 23, 42, 66, 88, 123, 175, 180, 188, 204,

- War Communism 35, 221

Communist Party of the Soviet Union (CPSU) 24, 112, 125

"The Confession" (Maupassant) 154, 156, 158, 159, 161, 162, 280n18

Conquest, Robert 78, 212

Conrad, Joseph 27, 165, 193 
Index

"Conversation with a Tax Inspector about Poetry" (Maiakovsky) 155

"Conversation with My Son" (Bagritsky) 23

Corneille, Pierre 32

Cossacks 37, 39, 41-45, 47, 48, 52, 53, 61, 88, 104, 126, 133, 134, 136, 143,

166, 171, 172, 174-177, 180-182, 186, 187, 189, 190, 192, 195, 197, 204, 275n 28

Cossacks (Tolstoy) 190

Crime and Punishment (Dostoevsky) 215

"The Cross" (Shapiro) 199

"The Crossing of the Nieman by Russian Forces on January 1, 1813"

(Batiushkov) 137

"The Crossing of the Rhine" (Batiushkov) 138

Czernowitz conference 21

Dan (Weintraub), Aleksander 63

Daniel', Iurii 81

Dante, Alighieri 168

Danton, Georges 168

David (King) 144, 145, 147

Decameron (Boccacio) 139

Deleuze, Gilles 112

Den' 110

Denikin, Anton 120

Denisova, Maria 150

Der Nister (Pinkhas Kahanovich) 89

Dickens, Charles 116

Dionysus 130

Dnieper (Feffer) 23

Dniepropetrovsk 57

Don Quixote (Cervantes) 279n15

Donbass 69, 210, 239, 247

Doroshevich, Vlas 98, 100

Dostoevsky, Fiodor 49, 87, 151, 162, 268, 280n21

Dovzhenko, Alexander 224

Dubnov, Simon 110

Dumas, Alexandre 53

"Dzhiro Dzhiro" (Bergelson) 89

Earth (Dovzhenko) 224 
Eastman, Max 68

Ecclesiastes 144, 147

Efimov, Boris 176

Efros, Abram 200

Ehrenburg, Il'ia 25, 67-69, 72, 73, 77, 81, 82, 227, 228, 239, 246, 247, 252n7, 266n124, 280n24

Eikhenbaum, Boris 89

Eisenstein, Sergei 70, 78, 193, 224, 240, 242, 245

El'sberg, Yakov 73, 264n113

Elijah 141, 142

Eliot, T. S. 86, 137, 201

End of the Gang (Kaverin) 102

Erdman, Nikolai 68, 70

Ermler, Fridrikh 195, 196

Esenin, Sergei 252n8

Esther Khayut (Shteynman) 112

Evenings on a Farm near Dikan'ka (Gogol') 171

Even-Zohar, Itamar 89, 114, 269n23; see also polysystem theory

Evgeny Onegin (Pushkin) 19

Evsektsiia 24, 112, 125

Ezekiel 122

Ezhov, Evgeniia (Khaiutina) 210

Ezhov, Nikolai 73, 74, 76-78, 80, 210, 239, 266n130

Fadeev, Aleksandr 27, 48, 75, 184-186

Fainzimmer, Alexander 240

Fallen Leaves (Rozanov) 32

Feffer, Itsik 23

Feierberg, M. Z. 119, 181

Feuchtwanger, Leon 208

Fichman, Ya'akov 111, 112

Figures and Anecdotes of the Great War (Vidal) 166, 231

First Horse Army 39, 43-45, 61, 120, 136, 150, 223, 226, 259n43, 261n66

First Love (Turgenev) 49, 156

"The Fit" (Chekhov) 163

The Five (Jabotinsky) 30, 102

Flaubert, Gustave 152, 153, 155, 281

Forever Flowing (Grossman) 224 
Index

FOSP 63, 224, 245, 257n15

Foundation Pit (Platonov) 223

Fragment of an Empire (Ermler) 195, 196

France 62, 63, 152, 153, 158, 159, 164, 168, 242, 245

France, Anatole 166

Francis of Assisi 132

French 16, 18, 27, 31, 32, 56, 62, 71, 72, 77, 79, 80, 90, 99, 108, 143, 152, 153,

$158,165,167,168,238,240,248,251,266 n 124,277 n 4,281 \mathrm{n} 27$

From Here and There (Hazaz) 125, 202

Frug, Simon 110

Furer, Benjamin 69

Furmanov, Dmitri 27, 46, 187, 188, 240, 247, 258n36n38, 260n63, 284n24

Galich, Alexander 264n119

Galicia 16, 39-41, 89, 99, 108, 120, 121, 190, 197

"Gambrinus" (Kuprin) 19

Gekht, Semyon 69, 88, 98, 239, 252n8

Gendelstein, Albert 240

Generation Goes, Generation Comes (Markish) 205

Generations without Hope (Bang) 123

German, Emmanuil (Emil' Krotkii)105

Gide, André 152, 153

Gilman, Sander 118

Ginzberg, Allen 110, 201

Glaser, Amelia 201

glasnost' 82, 265

Gnessin, Uri Nissan 112, 119

Gogol', Nikolai 27, 60, 61, 151, 171, 190, 239, 278n1

Goldberg, David Theo 15

Golden Chain (Peretz) 146

Golgotha (Greenberg) 199

Gor'ky Trilogy (Donskoi) 74, 240, 242

Gor'ky, Maksim (Aleksei Peshkov) 21, 34, 35, 48, 51, 59, 61-63, 67-69, 74, 77, 78, 81, 105, 112, 151, 156, 164-166, 190, 208, 210, 230, 237, 239, 240, 242, 244, 246, 251, 256n13, 261n67, 262n93, 263n102, 266n123, 279n15, 281n33

Gorbachev, Georgii 47

Gorbachev, Mikhail 82, 265n120 
Gordin, Jacob 89

Gordon, Yehudah-Leib 37

Govrin, Akiva 120

Granovsky, Aleksei (Abraham Azarch) 55, 241

Great Madness (Hameiri) 197

Greeks 16, 108

Greenberg, Uri Tsvi 199

Gronfein, Berta 54

Gronfein, Boris (Dov-Ber) 13

Grossman, Vasily 77, 224

Grosz, George 195, 196

Guattari, Félix 112

Gulag Archipelago (Solzhenitsyn) 224

Halevi, Yehudah 149

Hameiri, Avigdor 112, 197

Hamelits 110

Hamsun, Knut 198

Harshav (Hroushovsky), Benjamin 114, 274n18

Hasidism 39, 128, 141, 142, 230

Haskalah (Jewish Enlightenment) 17, 37, 99, 110, 173, 177, 181\

Hatekufah 124, 125

Hazaz, Khaim 105, 202, 204, 285

Heap (Markish) 201

Hebrew 12, 13, 15, 16, 18, 20, 22, 25-27, 29, 30, 42, 49, 51, 85, 90, 91, 94, 100, 106, 110-116, 118-126, 139, 144, 147, 149, 170, 177, 199, 201, 202, 207, 261n70, 274n17n18, 278n18, 286n7

"Hebrew Communist" (Shteynman) 124

Hebrew Melodies (Heine) 149

Heidelberg 130, 277n5

Heine, Heinrich 47, 118, 149

Hemingway, Ernest 207

Hershel Ostropoler 93, 177, 230

Hirschbein, Peretz 111

History of Jesus 139

History of the Russian State (Karamzin) 31

Hitler, Adolf 84

Horodysche (Horodishtch) 201-202 
Index

How the Steel Was Tempered (Ostrovsky) 194

Hunger (Hamsun) 198

Ibn Ezra, Avraham 115, 119, 147

Il'f (Fainzil'berg), Il'ia 17, 18, 25, 37, 70, 98, 113, 244, 247

"In the City of Massacre" (Bialik) 113, 121, 198

Inber, Vera 18, 102

Ingulov, Sergei 39

interference 85, 90, 91, 94, 99, 106, 115

intertextuality 19, 20, 85, 86, 87, 114, 251, 268n11

Iron Flood (Serafimovich) 192

Isaiah 105, 106

Israel 12, 17, 21, 92, 111, 119, 124, 177, 199, 205, 261n16, 274

Italian language 99, 168, 248

Italians 108

Iug-Rosta 39

Ivanov, Viacheslav 116

Ivanov, Vsevolod 58, 183

Jabotinsky, Vladimir (Zeev) 17, 21, 30, 102, 110, 113, 116, 121, 256n5

Jasieński, Bruno 62-64, 261n71

Jerusalem 22, 105, 106, 117, 119, 143, 149

Jesuits 130, 133

Jesus of Nazareth 145, 146

"The Jew" (Turgenev) 171

Jewish Chamber Theater: see State Jewish Theater (GOSET)

"Jewish Government" (Shapiro) 200

Jewish King Lear (Gordin) 89

Jewish Luck (Granovsky) 55

Jews (as stereotypes) 24, 51, 171

John the Baptist 131

Josephus Flavius 208

Joshua 145-146, 147

Joyce, James 27, 71, 162

Judaism 30, 33, 38, 94, 109, 115, 118, 123, 128, 177, 255n35

Judas Iscariot 132

Kabardino-Balkariia 69, 239, 246, 262

Kafka, Franz 120, 198

Kaganovich, Lazar 69 
Kaleidoscope (Rabinovich) 19

Kalmykov, Betal 69

Kamenev, Lev 71

Kapler, Alexei 240

Karakina, Elena 19, 208

Kashirina, Tamara 58, 60, 72

Kataev, Valentin 18, 77, 78, 81, 98, 244

Kenez, Peter 198

Kerensky, Aleksandr 36, 157

Khiog, Moshe (Grigori-Tsvi Plotkin, né Abramson) 123, 124

Khmel'nitsky, Bogdan (Bohdan Khmel'nitsky) 42, 121, 135, 143, 194

Khrenovoe 59

Khrushchev, Nikita 82

Kiev 13, 32, 33, 54, 105, 125, 126, 192, 193, 209, 210, 220, 223, 238, 239, 241, 242, 247, 285n41, 286n7

King (Yushkevich) 19

King, Charles 30

"Kingdom of the Cross" (Greenberg) 199

Kipling, Rudyard 168, 169

Kirov, Sergei 71

Kirsanov, Semyon 11

Kirshon; Vladimir 224

Kishinev 15, 92, 113, 121, 122, 126, 198, 201

"The Kiss" (Chekhov) 163

"The Kiss" (Shapiro) 200

Klier, John 16

"Kol Nidre" (Roizman) 91

Kolchak, Alexander 183, 187

Kol'tsov, Mikhail 75-77, 79

Kola Street (Asch) 113, 199

Kolbasina, Olga 242

Komsomol 22, 23, 70, 216

Kopelev, Lev 223, 224

Korenman, O. L. ("Karmen") 19, 38

Kotovsky, Grigori 60, 260

Kozakov, Mikhail 24

Krasnaia nov' 46, 75, 76, 183 
Index

Krasnyi kavalerist 39, 43, 177, 188

Krausz, Michael 15

Kremer, Izya (Isabella) 97

Krest'ianskaia gazeta 76

Kristeva, Julia 87, 268n11

Krug (publishing house) 75

Kultur-lige 126

Kuprin, Alexander 19, 98

Kutuzov, General Mikhail 138

Kvitko, Leib 126

Lachmann, Renate 85

Lava 39

Lay of Igor 137

Lay of Opanas (Bagritsky) 76, 101, 194

LEF (Left Front of the Arts) 46, 175

Lenin (Ulyanov), Vladimir 35, 42, 46, 47, 62, 88, 123, 124, 142, 174, 175, $180,186,237,282$

Leningrad: see St. Petersburg

Leon Drei (Yushkevich) 19

Leonov, Leonid 48, 102

Letopis' 34

Levidov (Levit), Mikhail 105

Lévi-Strauss, Claude 170

Lezhnev (Altshuler), Isai 68

Lezhnev (Gorelik), Abram 92, 281

Libedinsky, Yurii 186

A Life (Maupassant) 153

Lilienblum, Moshe Leib 110

Lissitzky, El 25

"The Literature Teacher" (Chekhov) 163

Literaturnaia gazeta 62, 63

Livshits, Isai 33, 209, 248, 260n63, 262n93

"A Lonely Star" (Bialik) 117

Lotman, Yurii 170, 171, 282n3

Lunacharsky, Anatoly 124, 148, 156

Lunts, Lev 21, 91

Madame Bovary (Flaubert) 152, 153 
Maiakovsky, Vladimir 46, 64, 124, 155, 175, 195, 201

Maimon, Moisei 24

Maimonides (Moshe ben Maimon) 42, 85, 94, 115, 119, 123, 124, 204

Makhno, Nestor 194, 206

Makotinski, M. Y. 209

Malraux, André 77, 81, 240, 266n123

Man Who Prostrated Himself (Kozakov) 24

Mandelstam, Nadezhda 73

Mandelstam, Osip 25, 53, 70, 74, 82, 86, 106, 157, 164, 273n63n64

Markish, Peretz 89, 126, 201, 205

Marranos 24, 92, 270n29

Marshak, Samuel 157

Mary Magdalene 132

maskilim: see Haskalah

Master and Margarita (Bulgakov) 84

Maupassant, Guy de 16, 19, 27, 35, 48, 72, 151-169, 207, 241, 243, 279n6n7, 280n19, 281n27

May Laws 30

Maynial, Edouard de 161, 167, 280

Meierhold, Vsevolod 75, 79, 265n121

Mel'nikov, S. 46, 258n37

Menakhem Mendel Stories (Sholom Aleichem) 55, 241

Mendel Mokher-Sforim (Sholem Yankev Abramovich) 26, 89, 90, 110, 111, 114,181

Mendele: see Mendel Mokher-Sforim

Michelangelo di Lodovico Buonarroti 132

Mikhoels (Vovsi), Solomon 78, 88, 89, 241, 260n62

Minkovsky, Pinkhas 38, 108, 109

Mir iskusstva 36

"Mire" (Chekhov) 158

Miserly Knight (Pushkin) 72, 228

"Miss Harriet" (Maupassant) 158, 280n16

modernism 12, 16, 20, 21, 26, 28, 71, 85, 86, 112, 200, 201, 207

Moldavanka 13, 31, 38, 53, 100, 102, 127, 272

Molière_Jean-Baptiste Poquelin 32

Molodaia gvardiia 47

Molodenovo 59, 64, 73, 208 
Index

Morits Sefardi (Rabinovich) 19

Morozov, Pavel 70

Moscow 11-14, 18, 19, 24, 35, 40, 42, 44, 47, 54, 56-61, 65, 73, 74, 77, 78,

$84,88,89,98,99,106,124,136,147,150,164,176,183,209,216,225$,

227, 229, 232, 233, 236, 237, 240, 242, 245-248, 257, 262n93, 263n103,

266n124, 267n135, 269n19, 280n26, 281n26

Moss, Kenneth 15, 20

“Motia Malkhamoves" (Sel'vinski) 102

Murav, Harriet 21, 205

Murillo, Bartolomé Esteban 132, 133

Muslims 187

Na postu 44

Nabokov, Vladimir 55, 56, 86

Nakhimovsky, Alice 21

Nakhman of Bratslav 142

Napoleon Bonaparte 137, 138, 143

Narbut, Vladimir 39, 268n8

Narkompros 35

Nazi genocide 17

Nekrasov, Nikolai 136

Nepomniashchi, Ya'akov-Shlomo 124

Nicholas I 135, 136, 138

Nigger of the Narcissus (Conrad) 193

Nikolaev 13, 32, 52, 58, 113

Nilsson, Nils Åke 155, 281n30

The Nineteen (Fadeev): see Rout

NKVD 73-75, 78, 80, 81, 209, 256n5, 265n120, 267n135

Noise of Time (Mandelstam) 53

Novaia zhizn' 35, 83, 105, 279n15, 281n33

Novograd-Volynsk 132, 135, 137, 171, 181

Novyi mir 60, 222, 224, 226, 288n 43

Odessa 11-14, 16-19, 23, 26, 27, 30, 31, 35-39, 42, 46-49, 53, 58, 60, 63, 65, $69,70,72,73,83,89,93-95,97-102,104,105,108-113,124,126-128$, $130,144,148,151,152,157,164,169,177,186,208-210,225,228,229$, 231, 232, 235, 237, 239-241, 244, 245, 253n14n18n19n20, 257n19n21, $264 \mathrm{n} 119,268 \mathrm{n} 8,271 \mathrm{n} 39,272 \mathrm{n} 50$

Odessa language $98-100$ 
"Odessa Tales, or the Incoherent Alphabet of Memory" (Polischuk) 13

Odessa, Odessa (Boganim) 18

Odessans (Ratushinskaia) 18

"Offense" (Kuprin) 19

Okhotnikov, Yakov 83

Oktiabr' 45, 46

Olesha, Yurii 18, 20, 67, 68, 70, 75, 78, 244

"On Literature, Revolution, and Entropy" (Zamiatin) 20

"On the Slaughter" (Bialik) 121

"On the Threshold of the Study House" (Bialik) 115, 116, 118, 119

"One Summer Evening" (Bialik) 118

Optimistic Tragedy (Vishnevsky) 259n43

"Origins" (Bagritsky) 23

Ostrovsky, Nikolai 194, 242

Oukaderova, L. 156

OZET 210

Paris 35, 54-57, 65, 71, 73, 77, 126, 167, 168, 227, 238, 244-246, 256n5, 257n15, 260n 57

Parnakh, Valentin 24

Pasternak, Boris 25, 68, 71, 72, 75, 82, 246

Pasternak, Leonid 13

Pater, Walter 32, 256n10

Paustovsky, Konstantin 18, 51, 165, 168

perestroika 12,82

Peresyp' 31

Peretz, Y. L. 146

Pereval 75

Peshkova, Ekaterina 81

Peter the Great 136

Petliura, Semyon 193, 194, 206

Petrograd: see St. Petersburg

Petrov, Evgeny 17, 18, 25, 70, 244

Petrov-Vodkin, Kuzma 150,

Pierre et Jean (Maupassant) 167

Pil'niak, Boris 20, 62, 68, 75, 77, 126, 215

Pilsudski, Josef 135, 184

Pinsker, Leo 110 
Index

Pinsker, Shachar 112

Pirozhkova, Antonina 58, 70, 72-74, 80-82, 84, 235, 250, 264n117, 265n120, 266n123

Platonov, Andrei 20, 223, 224

Poland 27, 43, 80, 135-138, 164, 193

Poles 39, 40, 42, 121, 122, 130, 135, 138, 143, 202-204

Poliak, L. 82

Polischuk, Rada 18

Polish 27, 36, 39, 41, 44, 46, 62, 63, 120, 130-135, 138, 143, 144, 163, 164, $172,175,178,180,188,195,197,198,199,205,247,258 n 37,261 n 71$, 271n48, 277n4, 282n5, 283n8

Polonskaia (Movshenzon), Elizaveta 91

Polonsky, V. P. 60, 226

polysystem theory 26, 89-91, 106, 114, 269n27, 274n18

Pravda 174, 175, 216, 218, 221, 261n67

Primakov, Vitaly 83

Prokofiev, Sergei 240

Proletkul't: see RAPP

Propp, Vladimir 170

Proust, Marcel 152, 153

Pugachev, Emelian 188

Pushkin, Alexander 19, 32, 49, 50, 72, 127, 128, 168, 194

"The Rabbi's Son" (Nakhman/Buber) 142

Rabinovich, Osip 19, 109, 110

Rabinowitz, Ya'akov 112

Rabon, Israel 27, 197, 198

Racine, Jean 32

Radek, Karl 71, 76

Radziwiłł, Janusz (seventeenth century) 135

Radziwiłł, Janusz (twentieth century) 135

"The Railroad" (Nekrasov) 136

RAPP 44, 46, 48, 182

Rashi (Rabbi Shlomo Yitskhaki) 15, 115, 147, 204

Rasputin, Grigori 158

Rassvet 110

Ratushinskaia, Irina 18

Ravnitsky, Yehoshua Khana 110, 111 
Razin, Sten'ka 188

Remarque, Erich Maria 195

Rembrandt, Harmenszoon van Rijn 132, 133

"Return" (Bagritsky) 23

Revolution (1905) 30, 200

Revolution (February) 34, 37, 41, 103, 111, 124, 230

Revolution (October) 12, 17, 24, 25, 27, 35, 44, 45, 47, 48, 82, 83, 85, 90, 92, 114, 115, 118-120, 122, 124, 125, 149, 168, 173, 175, 182, 204, 210, 217, $219,227,237,259$ n52

Ribbentrop-Molotov pact 80

Richelieu, duc de (Armand Emmanuel du Plessis) 108

Rifkind, Binyomin 243

Rodos, Boris 76

Roerich, Nicholas 158

Roizman, Matvei 91, 270n29

Rosten, Leo 91

The Rout (Fadeev) 27, 48, 184

Rozanov, Vasily 32

Rubens, Peter Paul 141

Rubin, Rachel 104, 272n50n58

Rumanians 18

Russian language 91, 98

Russian literature 16, 18, 19, 21, 24, 70, 94, 119, 126

Rybak, Issakhar-Ber 126, 201

"The Sabbath Queen" (Bialik) 118

Sapieha, Eustachy 135

Sapieha, Lew 135

Schmidt, Dmitri 83

Schoffman, Gershon 119

Schreurs, Marc 87, 138

Schwarzman, Lev 76

Sel'vinski, Il'ia 102

Serafimovich, Alexander 192

Serapion Brothers 20, 21, 91, 165

Serres, Michel 85

Shapiro, Lamed 199, 200

Shaposhnikov, Grigori 54 
Index

Shcheglov, Yuri 18

Shishov, V. F. 99

Shklovsky, Viktor 18, 20, 35, 70, 170

Shneer, David 20, 253n12

Sholokhov, Mikhail 28, 216-218, 222, 224

Sholom Aleichem (Sholem Rabinovich) 19, 25, 33, 55, 88, 89, 90, 103, 110, 241, 243, 251, 278n18

Shostakovich, Dmitrii 71

Shtetl (Vaisenberg) 121, 200

Shteynman, Eliezer 111, 112, 124

Siniavsky, Andrei 81, 82, 228, 258n26

Sinkó, Ervin 73, 209

Slavin, Lev 18, 98

Slezkine, Yuri 49, 259n48

Slonim, Anna 238

Slonim, Lev 13

Slonims family 14, 248

Slutsky, Boris 263n101

Smolenskin, Peretz 110

Sobolev, Leonid 68

Solitaria (Rozanov) 32

Sologub, Fiodor 116

Solzhenitsyn, Aleksandr 81, 84, 224

Song of Songs 141, 147

Sorrento 71

South Russian Telegraph Agency; see Iug-Rosta

"South-Western School" 18

Soviet Writers' Union 66, 75, 162, 247, 267n139

Spain 20, 77, 114, 156

spatial modeling 170, 171, 173

Spektor, Usher 210, 232, 239

Spinoza, Barukh 141, 177

Stakh, Tat'iana 74

Stakhanovite movement 69, 210

Stalin, Iosif 14, 18, 24, 28, 45, 47, 49, 60, 62, 66, 68, 69, 71, 73-75, 77, 80, 83, $84,92,211,212,216,218,219,224,239,243,261 n 71,266 n 123$

Stanton, Rebecca 19 
State Jewish Theater (GOSET) 88, 89, 260n62

"Steamship Ticket" (Ehrenburg) 25

Steiner, Bruno 77

Stetsiuchenko, A. A. 99

Stiebel, Avraham Yosef 124

Stoliarsky, P. S. 31

Storm Days (Bergelson) 206

Story of My Life (Svirsky) 25

St. Petersburg 13, 14, 16, 19, 34, 35, 71, 98, 105, 106, 110, 136, 148-152, 154, $156-158,160,161,164,221,230,236,237,243,264,270$

The Street (Rabon) 197

Stubborn Calendar (Polonskaia) 91

Sukhikh, I. 83

Summer Resort (Rabinowitz) 112

"Sunset" (Bialik) 117

Suvarin, Boris 73, 227

Svetlov, Mikhail 22, 23, 25

Svirsky, Aleksei 25

"Sweet Childhood" (Utkin) 92

Sylvester, Rochelle 31

"The Tale of Red-Headed Motele, the Tax Inspector, Rabbi Isaiah and Commissar Bloch" (Utkin) 92

Taras Bul'ba (Gogol') 61, 190

Tartu School of Semiotics 89; see also Lotman

Tel Aviv 112

Terye the Milkman (Sholom Aleichem) 33, 89, 90, 103

Thief (Leonov) 48, 102

Titus 133

Tolstoy, Lev 27, 49, 73, 152, 154, 155, 159, 161, 162, 166, 183, 190, 222, 278n2, 279n6, 280n21

Tomashevsky, Boris 170

"Tradition and the Individual Talent" (Eliot) 86, 137

Trebukov, Shimon ("Haboneh") 124

Trilling, Lionel 66, 262n87

Trotsky (Bronstein), Lev 36, 45, 74, 76, 88, 120, 157, 179, 180, 211

Tsion 110

Tsvetaeva, Marina 82 
Index

Tukhachevsky, Mikhail 45, 69

Turgenev, Ivan 49, 52, 53, 70, 153, 155, 156, 171, 207, 259n47

The Twelve (Blok) 105, 140, 195

Twelve Chairs (Il'f and Petrov) 25

Twersky family 142

Tynianov, Yurii 76, 89, 268n9

Ukrainian language 99-101, 112

Ukrainians 16, 40, 102, 108, 202

Under Fire (Barbusse) 106, 195

“Upon My Return” (Bialik) 119

Uritsky, Moisei 149

Uritsky, S. B. 76

Ussishkin, Shmuel 111

USSR in Construction 210, 239

Utesov, Leonid 99, 102, 245

Utkin, Iosif 23, 25, 92

"Vas'ka Svist Caught in a Trap" (Inber) 102

Vecherniaia Moskva 47

Vecherniaia zvezda 105, 106, 273n64

"Vendetta" (Maupassant) 166

"Verses about the Rebbe" (Svetlov) 22

Veshnev, Vladimir 47

Vidal, Gaston 39, 166, 231

Vilna 16, 110

Vilna Gaon 142

Vinnitsky, Moshe-Ya'akov ("Misha Yaponchik") 37, 38

Virgin Soil Upturned (Sholokhov) 28, 216, 218, 221-222, 224

Vishnevsky, V. 259n43

Volhynia 39, 88, 118, 120, 178

Volozhin 110, 119

Voronezh 59, 70

Voronsky, Aleksandr 19, 46, 75-78, 183, 266n130

Voroshilov, Kliment 77

VUFKU (All-Ukrainian Film Studios) 88, 209, 241

Wandering Stars (Sholom Aleichem) 88, 89

Warsaw 16, 62, 63, 65, 110, 112, 124, 135, 136, 197

The Waste Land (Eliot) 201 
"We will not drink out of the same glass" (Akhmatova) 101

What is Art? (Tolstoy) 162

White Guard (Bulgakov) 192, 193

"White Sabbath-Bread" (Shapiro) 200

Whither? (Feierberg) 119, 181

Wiadomości literackie 62, 63

Wisse, Ruth 104, 113

Woolf, Virginia 27

Yagoda, Genrikh 71, 74

Yakir, Iona 69

Yampolsky, M. B. 87

Yeats, W. B. 123

Yiddish 12, 15-18, 20-23, 25-27, 49, 50, 78, 85, 88-97, 99, 100, 102-106, 111, 112, 114, 115, 125-127, 142, 144, 146, 149, 170, 197, 199, 201, 205, 207, 241, 243, 247, 253n12, 260n62, 269n24, 270n31, 271n49, 272n50n59, 273n59, 274n17, 284n36n37, 285n41

Yushkevich, Semyon 19, 38, 110

Yusupov, Prince Felix 158

Zamiatin, Evgeny 20, 62, 68, 82, 98, 126, 270n37

Zarudin, N. N. 77

Zederbaum, Alexander 110

Zhitomir 40, 115, 119, 141, 177, 204

Zholkovsky, Alexander 87, 89, 278n18, 279n6

Zhvanetskii, Mikhail 13, 99, 271n39

Zinoviev, Grigory (Ovsei-Gershon Radomyslsky Apfelbaum) 71

Zionism 30, 31, 110, 112

Zola, Emile 153, 183, 198

Zoshchenko, Mikhail 12, 27 


